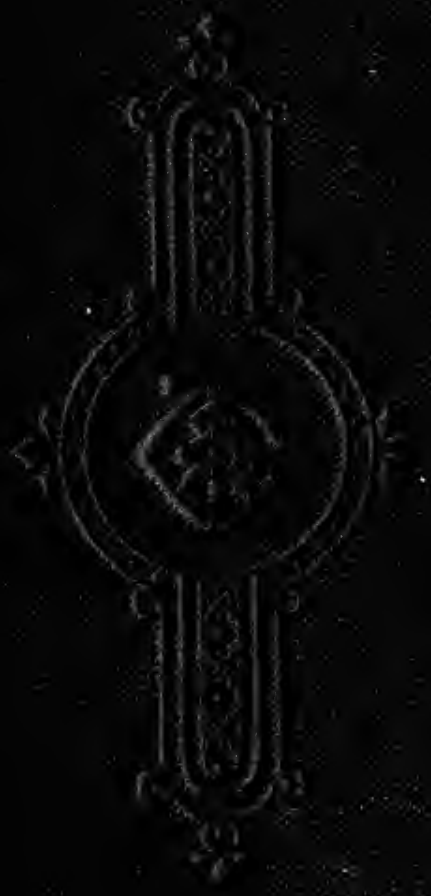




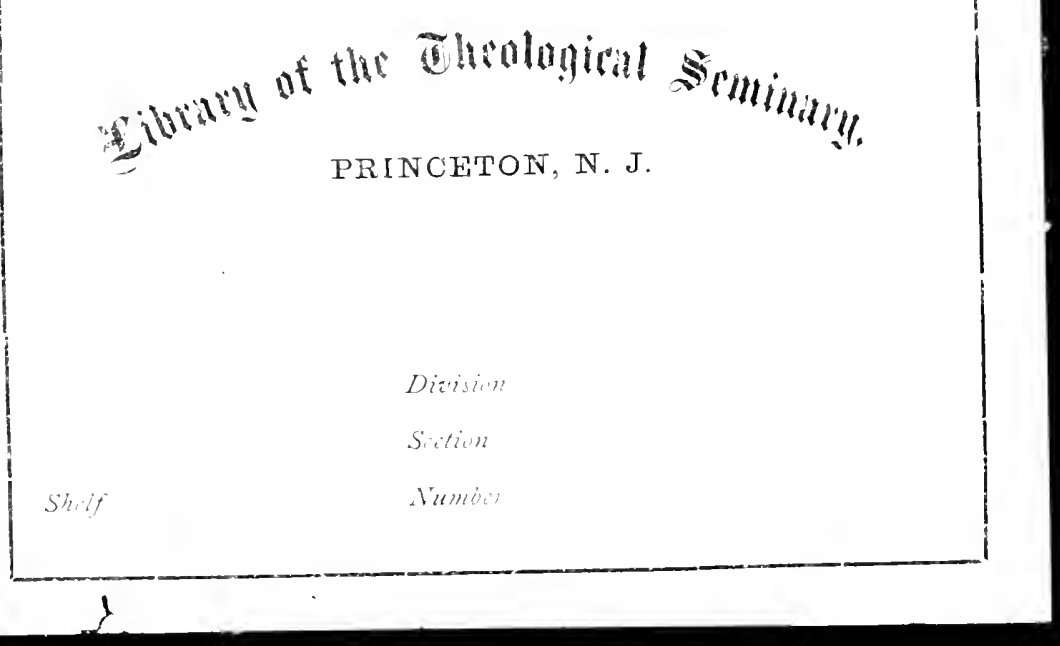




\section{INTRODUCTION}

To

\section{THE SYNOPTIC GOSPELS}


PRINTED BY MORRISOX AND GIBL:

roR

T. \& T. CLARK, EDINBURGII

LONDON : SIMPKIN, MARSHALL, HAMILTON, KWAT, AND CO. LIITEL

NEW YORK : CHARLES SCRIBNEY'S SOSS

TORONTO: THE WILLAPD TRACT DEPOSITORI 


\section{INTRODUCTION}

TC

\section{THE SYNOPTIC GOSPELS}

FI

PATON J. "GLOAG, D.D.

ALTHOR OF

A COMMEXTARY ON THE ACT OF THE APOSTIE

AS INTRODTCTION TO THE PAILINE EPISTLFA

AN INTRODLCTION TO THE CATHOLIC EPISTLK

AN IXTRODECTIOS TO THE JOHANXISE WRITIXIX

FTC. FTC.

E D I N B U R G H

T. \& T. CLARK, 38 GEORGE STREET 1895 

THIS WORK

IS DEDICATED TO

MY WIFE,

WHO HAS UNWEARIEDLY ASSISTED ME

IN THIS AND IN ALL MY OTHEI: LITERARY LABOCRE- 



\section{PREFACE}

TiIIs Introduction to the Synoptic Gospcls completes a series of Introductions to the books of the New Testament, in the preparation of which I have been engaged for a quarter of a century. The Introduction to the Acts of the Apostles, with a commentary, was published in 1870 ; the Introduction to the Thirten Pauline Epistles, along with the anonymous Epristle to the Hebrews, in 1874; the Introduction to the Scven Catholic Epistles in 1887; the Introduction to the Johanninc Writings, especially the Fourth Gospcl and the Apocalypse, in 1891; and now the Introduction to the Synoptic Gospols in 1895. The design of these Introductions was not to give any explanation of or commentary on the sacred text (that to the Acts of the Apostles forming an exception), lnt to examine the gennineness of the writings, their authorship, the readers to whom they were primarily addressed, their design, their sources,-especially the sources of the historical books, - the langnage in which they were witten, their peculiar style and diction, their characteristic features, the integrity of the text, the time when and the place where they were witten, and their contents, in short, all that is necessary for their full understanding and intelligent perusal.

Several controversial points have been discussed in all these Introductions; but none of them has presented so many difficulties and perplexities as this Introduction to the Synoptic Gospcls. Critical controversy and inquiry have, in recent years, in a great measure passed from the investigation of the Pauline Epistles, to which they were directed by the 
ingenious investigations of Baur and the Tubingen school concerning Petrine and Pauline Christianity, and from the important question concerning the anthorship of the Fourth Gospel, which recent discoveries of patristic ducuments and a more rigid examination of the writings of the Fathers have in a great measmre settled, to the great problems connected with the origin and sources of the Synoptic Gospels. I do not allude to the mythical theory promulgated by Strauss, which, at least in its original form, may now be regarded as antiquated, but to the question whence the synuptists derived their information, and to the causes of the remarkable coincidences and equally remarkable differences which are found in their writings. This so-called "Synoptic probiem" is one of the great disputed questions in the biblical criticism of the present dity. In this Introduction I have discussed it at considerable length, first giving the most important theories that have been adranced, and then stating what I consider the most probable aproruaches to the truth. I am very far from supposing that I have arrived at any satisfactory conclusion, and am perfectly aware of the objections to which the theory advanced is exposed, and to which I can only give an imperfect answer: all that I have hecu able to do is to state what appear to me to be the most probable results of the incuiry. The complete solution of the problem is, I fear, for the present mattinable.

Another question, abont which it is still impossible to pronomece an opinion with eonficlence, has regard to the original language of the Gospel of Matthew. Here the external and internal evidences conflict. Dean Alfurl observes: "I find myself constrained to alamdon the view maintained in my tirst editim, and to adopt that of a creek original." My experience hats been preeisely the reverse. It first, giving weight to the internal evidence, l considererl that this Gospel wats originally written in Greek, and conld not have been at translation; hut, owing to the overwhelming weight of the external evidence, as secm in the monimoms and unopposed testimony of the Fathers, I have heen led to change that opinion, and nuw consider the hypothesis of a Hehrew or Aramaic original as 11 mon the whole the nore probable: muless, 
indeed, the hypothesis be adopted that there were two originals written by Matthew, the one in Hebrew and the other in Greek.

With regard to two other points of much difficulty, I have eome to the eonclusion, in opposition, it must be confessed, to some of our greatest biblical scholars, that the last verses of Mark's Gospel (xvi. 9-20) are genuine and formed an original portion of that Crospel; and that the variations in our Lord's genealogies, as given in the Gospels of Jatthew and Luke, can only be aecounted for on the supposition that Matthew gives the genealogy of Juseph and Luke that of Mary.

It is, I trust, wholly mmecessary to say that in this work I have endeavoured to exereise strict impartiality. I have pratised that candour which I have so strongly recommended as an indispensable yualification in all interpreters of scripture. I am not conscious of having given undue preference to any preconceived ophinions or traditional views. On the contrary, I have been fer in the course of my investigations to modify and alter several of my former views, although, I confess, with some reluctance, and only after eareful and repeated examination. A notable instance of this may be seen in the view maintained in this Introduction of the origin of the "Sermon on the Mount." Certainly the opinion, that this was one comnected discourse delivered at one time, is that which a perusal of it in the Cospel of Matthew lusst naturally suggests: but I have been led to think that whilst a large portion of it was delivered on a single occasion, ret other sayings of our Lord, given at difterent times and on different occasions, were added by the Erangelist, as is suggested by the fact that the same statements are found in different portions of the crospel of Luke, and there mentioned in their historical commection.

This Introduction may be regarded by different clisses of readers from different points of view. Sone may look "lon it as too conservative, and as not naking proper allowance for those advanced critical views which are now so prevalent; while others may regard it as too rationalistic, yielding too much to the views of those who are eonsidered by many as deniers of inspiration. All that I can say is that I have endeavoured to be honest to my own eonvictions. 
In recent years great progress has heen made in the text and criticism of the New Testanent, and new light has in consequence been cast on many controverted problems. Mannscripts and versions have been carefully collated, and the various readings compared. We have now a more certain text: the additions to the original, inserted in the textus receptro, are now removed, and omissions are now supplied. The result is that we have now obtained a text almost approaching to a restoration of the original. Of course, the readings of the oldest and uncial manuscripts still occupy the first place, but more attention has recently been paid to the cursive manuscripts and to the readings of the versions, especially the Old Italic and syriac, which have perhaps hitherto been too much undervalued, seeing that they were made from (ireek manuscripts much older than any which we now possess. A more accurate scholarship is now applied to the elncilation of Scripture; and the peculiar character of the dialect of New Testament Greek is now better understood. In the Rerised Version, whatever may be its defects, we have undoubtedly a much better translation than in the Authorised Version.

Within the last half century there have been several discoveries of remilrkable manuseripts, which have had an important bearing upon varions questions comnected with biblical criticism, especially upon the genumeness and age of the different scriptural books. The Philosophommena, ar Refutation of all Heresies, by IIiprolytus, in which the references of the early Gnosties to the books of the New Testament are quoted, was discovered at Mount Athos in $1 s+1$, and printed by the Claremlon l'ress, Oxfort, in 1851. A complete mamuscript of the clementine Homilies was found in the Vatican hy loressel in $18: 3$, and pullished at Göttingen in 185: H. In 1858 , Canon c'ureton published a Syriac manuscipt containing fragments of the (iospels, found by Areheleacon Tattan in a syriat momastery in the Nitzian desert in Eigrpot, and which is now reginded hy many as the oldest syliale rersion. This rersion wils likt year nearly completed ly the important disenvery of the Sinatic Syriac mannerifot by Mrs. Lewis, if the smpposition he 
correct that it is a variant copy of the Curetonian. The important Sinaitic manuscript, being, next to the Vatican, the oldest in existence, and materially affecting the reading of the received text, discovered by Tischendorf in the monastery of St. Catherine on Mount Sinai in 1859, was published in 1862. A complete copy of the Epistle of Barnabas, hitherto imperfect, was attached to the Sinaitic manuscript, and another copy was among the documents discovered by Bryennios. But, next to the Codex Sinaiticus, the most important of all these discoveries is the Diatessaron of Tatian. A translation in the Armenian language of Ephrem's commentary on that work was found in the Armenian convent at Venice, and was printed in that city in $18: 36$; a Latin translation was published in 1876, from which it was proved beyond the possibility of doubt that Tatian's Harmony was made up of the four canonical (iospels; and only a few years ago another manuscript was found by Professor Ciasca in the Vatican Library containing an Arabic translation of the whole work. Another very important document, the "Didache," or the "Teaching of the Twelve Apostles," was discovered by P'hilotheos Bryennios, Metropolitan of Nicomedia, in the Jerusalem convent in Constantinople, and published in 188. , which is considered by competent anthorities to have heen written about the close of the first century and to be the oldest post-apostolic docment extant, except the Epistle of Clemens Romanus, and possibly the so-called Epistle of Barnabas. Bound in the same volume with the Didachè was the only complete manuscript of the famons Epistle of Clemens Romanus, the copy in the Codex Alexandrinus being defective at the close. In 1889, J. Rendel Harris of Cimbridge discovered in the monastery of Mount Sinai the A pology of Aristides to the Emperor Hadrian. A very important fragment of the apocryphal Gospel of l'eter, found in a tomb at Akhman, in Upper Egypt, by the French Architological Mission at Cairo in 1886 , was published in 1892. And only last year the discovery of an important Syriac version of the fom Gospels was made by Mrs. Lewis in that Sinaitic monastery which has yielded so many important biblical manuscripts. These documents lave been 
discovered in different quarters-the Sinaitic manuscript and the new Sinaitic Syrian version in the monastery of st. Catherine, Mount Sinai; Ephn'm's commentary on the Diatessaron in the Armenian convent at Venice; the Arabic version of Tatian, partly in Egypt and partly in liome; the I'hilosophommena of Fippolytus in Momt Athos; the Didachè, and the complete coly of the Epistle of Clemens liomanus, in Constantinople; and the fragment of the ciospel of Peter in Egypt. The Vatican Library las also yielded many important treasures.

These recent discoveries of liblical documents fill us with the hope of still more important discoveries in the future, when the libraries of the monasteries shall have been more carefully examined by competent scholirs. The discovery of the writings of Papias, of the Gospel of the Hebrews, and of the Gospel of Marcion would be an enormous gain to biblical criticism, and might elucidate many unsolved problems; and who, viewing the past discoveries so mexpectedly made, can aftirm that such discoveries may not be within the boumls of prohability? At the same time, we do not believe that such discoveries will materially affect the main conchsions already arrived at, but rather that they will elucirlate questions which still remain unsolved or donbtful.

The present work forms a companion rolume to the other Introductions formerly published, and completes the series of hutroluctions to the New Testment. The seriptural fuotations are taken from the Revised Version, extept on those rare oxeasions when the Anthorised Version or an intrpentent translation appear's preferable. The patristic quotations are taken from Kirchhofer's onellensummlung :ur Geschichte ales neutestumentlichen C'tnons. Alprendices an attiched, referring to certain sperial diftienlties and disputerl

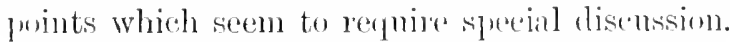

1 list of the most important books real of comsulted is aldeneled at the end of this work, with references to the colitions in my presession, so that the quotations mate from

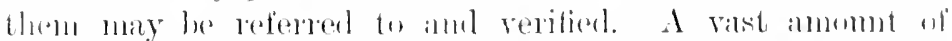

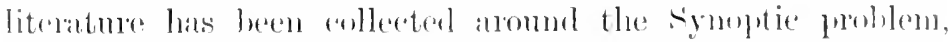

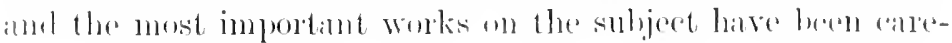


fully read whenever they could be obtained. It would, of course, be an endless task to refer to periodical literature on the subject, but I may mention several important articles which appeared in the Expositor for 1891. As in almost all theological discussions, we must betake ourselves to the great German theologians, whose works on the Synoptic problem have been carefully studied. Of these, I would especially mention the works of Holtzmam, Weiss, Wendt, and Paul Ewald. Of English theologians, the researches of Professor Sanday of Oxford on the Synoptic question call for special notice. They are distinguished alike by patience, cantion, and logical acmmen, and in point of learning and exhaustive investigation are unsurpassed by the above (ierman theolo. gians. It would not he right to omit special reference tr the Introductions of the venerable Dr. Samuel Davidson, however much we may dissent from his conclusions. His two Introductions, - that entitled Introduction to the New Testament, published in 1848, and that entitled Introduction to the Study of the New Testament, published in 1868, the third edition of which appeared last year (1894), when the anthor was in his eighty-eighth year,-though written from different standpoints, are most valuable, and exhibit a learning and researeh seldom equalled by any biblical critic in on country. I have found several commentaries very helpful, especially those of Meyer, Godet, and the late Dr. Morison, whose eommentaries on Mattlew and Mark are deserving of careful study. Several monographs on particular subjects have also to be mentioned, from which I have derived considerable assistance, as that of Dean Burgon on The Last Twelve Verses of St. Mark, Bishop Hervey on the Gencalogies of our Lord, Resch's Agrapha, and Zumpt's Das Geburtsjahr Christi. The value of Rushbrooke's Synopticon is acknowledged in the body of the work.

Last year (1894) I wrote six articles in the Thinker on the Synoptic problem. These, with the kind permission of the editor, the Rev. Joseph Exell, I have freely used in writing this work: they have, however, been rewritten and much altered both by additions and omissions.

It is my pleasing duty to acknowledge my obligations tu 
several friends who have kindly assisted the in this workto the liev. William Hastie, D.I., I'rofessor of Divinity in the Eniversity of Glasgow, and to my brother, Lord Kincairney, for perusing the manuseript before the work went to press, and for valuable hints and suggestions; and to the liev. David Inuter, D.D., of (ialashiels, and the lier. John Patrick, I).I., of Greenside, Edinburgh, for the veritieation of my references, and assistance in the correction of the press. 


\section{CONTENTS}

\section{GENERAL INTRODUCTION.}

Literature. I. The Title: Symoptic Gospels-Use of the term Gospel-Difference between the Synoptics and the Fourth Gospel-Number of the Gosprels- Encanonical Gospels-Fragmentary nature of the Gospels. II. Authors of the smoptie Gospels-Erangelieal Symbols. II I. Genumeness of the Srnoptie Gospels-The Testimony of the Fathers-The Gospel of Peter -The Muratorian Canom-Tatimn's Diatessaron-Testimony of Justin Martyl-Statement of Papias-Versions-The Old Latin - The Srriac-('relibility of the Narrative. IV. Relation of the Srnoptie Gospels to each other-Points of Agreement-Rushlrook's symopticon-The 'Threefold Narrative-The Twofold Narrative-The single Narrative-Summary of Resemblances-Existence of Doullets - Points of Diflerence-Narrative of the Birth of Christ--The Sermon on the Mount as given by Matthew ant Luke-The Passion-The Resurrection-ChronologicalOrder. V. Sources of the Symoptic Gospels - The Problem stated: A. The theory of Mutual Dejendence-The uriginality of Mark -Relation of Matthew and Luke to Mark-Relation of Luke to Matthew; $B$. The theory of an Oral Gospel-Wright's hypothesis of Catechetical Sehools-Modification of this theory W. Alford ; C. The theory of an original Document or Document- Modification of this theory hy Eichhom, Bishoj Marsh, Schleiermacher, Ewald, Albott, and Smith of Jordanhill-Smpposition of an Aramaie or Hebrew Document; $D$. The theory of two Documents- Nature of this theory-Statement of Papias -Meaning of the term Logia used $\mathrm{by}$ lim-Modification of this theory loy Holtzmam, Weiss, Wendt, Resch, and Sanday-Result of this Discussion. VI. Interpretation of the Synoptic GospelsCritical Apparatus-Erlitions of the Greek Text-The Revised Version-Necessity of Candour-Acquaintance with the times of Christ-Nature of Inspiration-Alleged discrepancies in the 
Gospels- Instane of the Blind Man at Jerieho-Sympathy hetween the Reader and the Writings--Spiritnal DiscermmentTeaching of the Synoptics compared with that of the other New Testament Writings-Distinctive peculiarities of the Synoptics. VIl. Hamony of the synopties,

\section{THE GOSPEL OF MAT'THEW.}

Literature. I. Genumeness of the Gospel-Extermal EvidenceInternal Evidence-By whom disputed-Examination of Oljections. II. The Anthor of the Gospel-Notices of Mattlew in seripture-Suplosed distinction between Ilatthew and LeviNotices of Mattlew in Eeclesinstical History. III. Sourees of the Gospel-Three Sonrees stated: Personal Observation, Oral Tratition, Written Documents. IV. The Design of the Gospel - Written for Jewish Christians-Proofs of the Meswiahship of Jesus. T. Original Languige of the Gospel-Difficulty of this Subject-Theory of a Hebrew Original-Extemal Evidence in favour of it-Uniform Testimomy of the Fathers-This Evirence disguted-Internal Evidence against a Helsew Original -The Greek Text not a Translation-Translation of Aranaic "xpresions-Identity of Greek expressions in Matthew with those in the other Synoptic Gospels-Hypothesis of two original Gospels, the one Helrew and the other Greek-Opinions of Crities. The Govel accorling to the Hebrews-An interpolated Gospel of Matthew-Additions foumd in it-Language of Judara in the Days of Christ-Style and Diction of Matthew. VI. Integrity of the Gospel: 1. Narlative of our Lord's Birth, Yatt.i.-ii._Evidence in its farour-Ol,jections to it - The Visit of the Magi-The Slaughter of the Infants of Bethlehen-A] larent liscrefancies with st. Luke's Narrative-Chromological urler of cresuts; 2. Doxology to our Lord's Prayer. VII. Date of the lispel--1)ifferent Opinions-The eirly Dite before A.D. 60The later Dite after A.D. 60-Reconeiliation of these two lates

Place of Comporition. VIII. Contents of the Gospel--1)isertatien: Cuotutions from the Old Testement. List of Quotations Lies of the Septuagint-Formule and llowes of QuntationExamination of some liflicult Parsigge-: 1. Matt. ii. 15, "Ont of ligyle have I "iblled my son"; 2 . Matt. ii. 17, 18, slauglater of

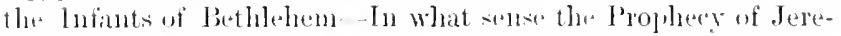

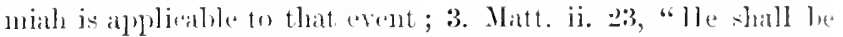
ralled a Nazinene" -Diflerent explanations: a los l'ropleer, a

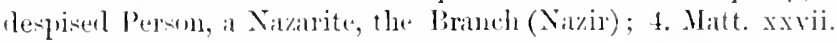

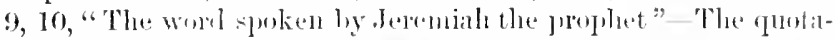
tion from \%orl. xi. 12, 1:3- Dillerent explantions: in the

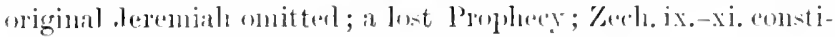

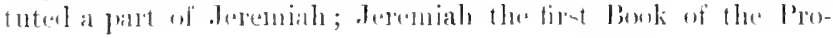


etical Division; the quotation from Jeremiah ; a quotation m two Prophets; designed to show the unity of Prophecy; nistake of the Author; a mistake of the Copyist,

\section{TIIE GOSPEL OF MARK.}

erature. I. Gennineness of the Gospel-External EvidenteInternal Evidence-By whom disputed-Examination of Objections. II. The Anthor of the Gospel-Notices of Mark in Scripture: Supposition of two Marks; the one the Diseiple of Paul, the other the Disciple of Peter-Supposed to he the young man who followed Clurist (Mark xiv. 51,52)-Notices of Mark in Eeclesiastical History. IIl. Sourees of Mark's Gospel-Negatively, not the Gospels of Mattlew and Luke-l'ositively, the Preaching of Peter-Statenents of the Fathers-Comection between Mark and Peter-Meaning of expression "Interpreter of Peter." IV. Design of Mark's Gospel-Written for Gentile Christians. V. Language of Mark's Gospel-Greek the original Langnage-Style and Diction-Quotations from the Old Testament-Characteristics of Mark's Gospel : its brevity, vividness, realistic character. VI. Integrity of the Gospel-Gemuineness of Mark xvi. 9-20-By whom disputed and defended-The External Evidence against and for its genumeness-lnternal Evidence against and for its genumeness-On the abrupt Conclusion-Resnlt arrived at-Opinions of Critics. VII. Time and Place of Writing-Conflicting Opinions of the Fathers-Written before the Destruction of Jemualem-Probable Date-Place of Composition-Probably Casarea. VIII. Contents of the Gospel -List of Miracles and Parables, . . . . . . 167-208

\section{THE GOSPEL OF LUKE.}

Literature. I. Genuineness of the Gospel-Testimonies of the Fathers-Argument drawn from the Acts of the Apostles-Statement of Oljections: 1. An amplification of the Gospel of Marcion-Views of Mareion-The Gospel of Marcion-Its relation to the Gospel of Luke-A mutilation of it;2. Tuke's Gospel, the work of an Elionite. II. The Author of the Gospel - Notices of Luke in Seripture and in Ecelesiastical History-Connection between Lake and Panl. 1II. Sources of Lake's Gospel-The Preface (Luke i. 1-4) : 1. Oral Tradition; 2. Written I ocuments-Relation of Luke to Matthew and Mark. IV. Design of Luke's Gosprel-Ardressed to Theophilus- Written for Gerntile Converts. V. Language of Luke's Gospel-m Purity of the Greek Style and Diction. VI. Claracteristics of Luke's Gospel -Its universality-The Gospel of the Humanity of ChristProminence given to Women-Contrasts in Luke's Gospelspiritual Songs-Value of Luke's Guspel. VII. Integrity of 
Luke's Gospel : 1. The Narrative of our Lord's Birth, Luke i.-ii. ;

2. Different Readings of Luke ii. 14; 3. The Lord's Prayer, Luke xi. 2-4; 4. The Bloody Sweat, Luke xxii. 43, 44-Evidenee for and agrinst its genmineness. VII1. Tine and Place of Writing-Date inferred from the Acts of the A postles-Supposed to be written after the Destruction of Jerusalem-Place of Composition. IX. Contents of the Gospel-List of Parables and Miracles-Dissertation I.: The Geneulogies. Literature on the subject-Points of Agreenent and l)ifference between the Genealogies of Matthew and Luke-The Sinaitie Palimrsest of Nrs. Lewis-Its bearing on the Genealogies-Its importance overestimated-The Genealogieal Lists-Peurliarities in Matthew's Genealogy-Genealogy from Sahmon to David-Omission of three Kings-Omission of Jehoiakin-The threefold Division of Matthew's Genealogy-The Cienealogy in Luke's GospelOn Shealtiel and Zerublabel-Three theories of Reconciliation of the two Genealogies: 1. The hypothesis of a Levirate Marriage-Statement of Julius Africanus; 2. The hypothesis that loth are the Genealogy of Joseph-No Evillence from this that Jesus is the Son of David-Ou the Davidic Descent of Christ; 3. The hypothesis that Matthew gives the Descent of Joseph and Luke the Descent of Mary-Critical Interpretation of Luke iii. 23-Conchusion arrived at-Genealogy among the Jews. Disiertation II.: The Census of Quirinius: Luke ii. 1, 2. Literature on the subject-Critical remarks-On the Census of the Roman Empire-Different methods of Chronology-The Census embraced Judrea-Date of our Lord's Birth-Herod alive when Christ was born-The Census of Quirinin-Statement of Josephus in conflict with Luke-Dillerent solutions: 1. Conjectural emendations; 2. The enrolment was male before (Moirinius was Governor; 3. Completed hy Quirinius ; 4. Quirinius an extrabrlinary commisioner; 5 . Called by his wellknown oflicial name-lnvestigations of /mupt-Qmininis wats twice fovernor of Syria-Arguments in support of this factSepulehral Inseription fommel at Tivoli-Results of the Investigition,

IERA'TA.

l'iugr 1, 1. 12, for 1862 read 180\%.

, (i, l. 21, for Synoptists reul Sirnopties.

"15, l. 15, for uncinonised read uncamonical.

". Hi, last lime, for Mark reed Matthew.

" it, I. \&, for beforehand read lefore him.

"5i3, 1. 20, for consistencies rend coincidences.

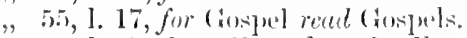

$" 72$, I. 17, for whlleded roed collated.

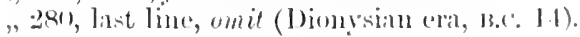




\section{THE SYNOPTIC GOSPELS.}

\section{GENERAL INTRODUCTION.}

Literatule.-The Literature on the Synoptic Gospels, taken conjointly, is very extensive, as the subject has of late attracted much attention in this country, in Germany, and in America.

The Genuineness of the Synoptic Gospels is treated in the special sections in the Introductions to the New Testament. The most important of these by German critics are those of Bleek (translated 1869; the last German edition much altered by Mangold, 1886), Credner, De Wette, Eichhorn, Guericke, Hilgenfeld, Holtzmann, Hug (translated 1827), Michaelis (translated by Bishop Marsh, with valuable notes and dissertations, 1802), Reuss (translated 1884), Weiss (translated 1887). Of works by English critics may be mentioned Alford's Prolegomena to his Greek Testament; the two very different Introductions of Dr. Samuel Davidson, the one entitled Introduction to the New Testament (1848), and the other Introduction to the Study of the New Testament (1868; third edition 1894); Dod's Introduction to the New Testament, 1888 ; Horne's Introduction to the Seriptures, with additions by Davidson and Tregelles, 1874; M'Clymont's The New Testament and its Writers, London, 189:; and Samon's Introduction to the New Testament, 1885. To these have to be added Professor Sanday's Gospels of the Second Century, 1876 ; Westcott's Canon of the New Testament, 1860 ; and Andrews Norton's (of Harvard University) Evidenees of the Genuineness of the Crospels, 1847. Jones On the Canon, Lardner's 
Credibility, Kirchhofer's Quellensammlung, and Charteris' Canonicity, contain the references to the Synoptic Gospels in the writings of the early Fathers. The special references in the works of Justin Martyr are discussed at considerable length by P'urves in his Testimony of Justin Mrertyr to curly Christianity (New York, 1888), and Sadler in his Lost Gospel (London, 1876). Tischendorf's tractate, Wann muren unsere Evangclien verfasst? (4th ed. 1866 ; translated 1867) has never been refuted.

The important question as to the origin of the Symoptic Gospels has been much discussed eluring the latter half of this century, and at no period more so than in the present day. The following are the most important works on this subject, given alphabetically: the article on the Gospels by Dr. Abbott in the Eneycloparlia Britanniea; Baur's Marcusevangelium, 1881; Badham on the Formation of the Gospels, London, 1892 ; Bleek's Synoptische Erliärung der drei ersten Evangelien (Leipzig, 1862); Eichhorn's theory is contained in his Einleitung in das N.T., and the remarks on it by Bishop Marsh in his translation of Michaehis' Introduction; Paul Ewald's Hauptproblem der Evangelienfraye (Leipzig, 1890); Ewald's Die drei ersten Eiangelicn, 1871 ; Gieseler's Historisehkritiseher Versuch wiber die Entstehung und dic friihesten Sehicksale der schriftlichen Evanyelien (Leipzig, 1818); Godet, "The Origin of the Four Gospels," in his Studies in the N.T. 1873; Holtzmann's Die synoptischen Erangelien, 1863: Hilgenfeld, Die Evangclien nach ihrer Entstchung und geschichtlichen Bedeutung, 1854; Jolley, The Synoptic Problem for English Readers (London, 1893); Keim's Jesus of Tasure (translated 1876-1883); Morison's Commentar!y on st. Mreplis Gospel (3rd ed. London, 1882); Norton's Genmineness of the Gospels, already adverted to; Resch, Aymopha: ausscrkanonische Evangelicnfrugmente, 1893 ; Roberts, Lanyuage of Christ and His Apostles, 1888; Sabatier's S'sures de la Vie de Jesus, P'aris, 1866 ; Sehenkel's Thes Cheraliterbiln Jesu (1864; translated 1869); Sehleiermacher's St. Lalke, especially the introduction to it by the translator, Bishop Thirlwall (Lonlon, 1828) ; Seholten's Des ulteste Eranyclium, 1869 ; Smith's Dissertation on the Cospcls, Edinhurgh, 
1853 ; the Introduction to the Gospels in the Spalier's Commentury, by Archbishop Thomson, and his article on the Gospels in Smith's Dictionary of the Bible (in the new edition there is a valuable supplement to that article by Professor Sinday); Volkmar's Mareus und die Synopse der Evanyelien, 1876; Weiss, Das Nereus Eiangelium und scine Synoptisehe Parallelen, 1872; Wendt, Erangel. Quellenberiehte iuber die Lehre Jesu, 1886; Weizsïcker, Untersuchungen über dic evangelische Gesehichte, 1864, and his Apostolisehes Zeitalter, 1890, now translated 1894; Wright's Composition of the Four Gospcls, London, 1890. Besides these, there are many important articles on the origin of the Synoptic Gospels by Dr. Sanday, Professor Marshall, and others in the Eupositor, fourth series, vol. iii. The subject is also discussed by Dr. Schaff in his History of the Christian Chureh (vol. i. pp. 575-612). To these also is to be added Rushbrooke's Synopticon; or an Exposition of the common matter in the Synoptic Gospels, where the matter common to the three Gospels and the matter common to two of them are so distinctly indicated by different types and colours as to be recognised at a glance. Other important works will be mentioned in the course of this Introduction.

A list of the chief Harmonies of the Gospel will be given when the Harmony of the Synoptics is discussed.

\section{The Title: Synoptic Gospels.}

The word Gospel is a translation of the Greek evaryé It probably came into use through Wicklif's translation. It is a contraction for Godspel, God's word, or more probably for Goodspel, good news (from spellian, to tell). The English version is the only European one in which the Greek word is translated; in other modern languages it is reproduced after the modified form of the Latin ivangelium, as in German Evangelium, in French crangile, in Italian crangelo, etc.

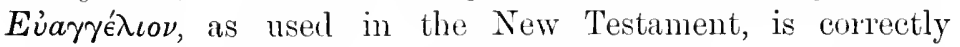
rendered yood news, and primarily denotes a good message; hence the glad tidings of salvation announced to the world in connection with Jesus Christ. Thus the angel on the plain 
of Bethlehem proclaimed: "Behold, I bring you good tidings

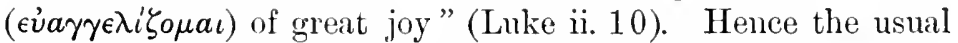
phrase, "the Gospel of Jesus Christ"; because Christ was the subject of these good news. Taken in a general sense, the word came to denote the whole revelation of salvation by Christ. Thus Paul speaks of "my gospel" (2 Tim. ii. 8), that is, the system of salvation which he preached. It was only at a later perior that the term came to be applied to a written reeord, and espeeially to denote the reeord of the sayings and doings of Christ, as in its applieation to the four historical Lives of Christ which form our canonical Gospels. We have a trace of this application in the introductory words to St. Mark's

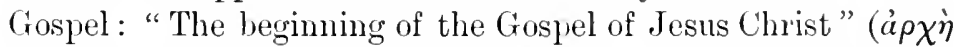

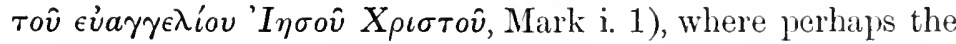
evangelist entitles his work a Gospel. In the writings of Justin Martyr we have the first molonbted use of the term in this sense: "For the apostles," he observes, "in the memoirs composed by them which we call Gospels, have thus declared." I

The superscriptions to the Gospels in the manuscripts of

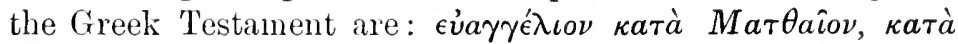

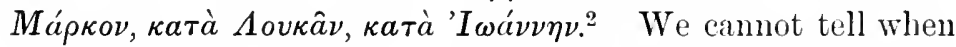
these titles were affixed to our Gospels; but as these titles are all similar, it is probable that it was not until they were collected together in a volume. The force of the preposition $\kappa a \tau a ̀$ has been variously explained. It may denote that the tractitions eollected by Matthew, Mark, Lnke, and John, i.c. their oral teaching, were committed to writing or edited by others, so that, according to this view, these evangelists were only the indirect anthors of their Gospels. It is thus mulerstood by Credner ${ }^{3}$ and others. But the general testimony of the Fathers is opposed to this meaning of the preposition; for

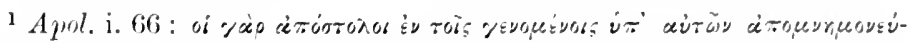

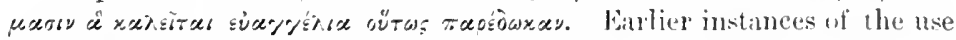
of the term are fomml in the Didache, and in the Elostle of Ignatius to the Philarlelphians, $r$.

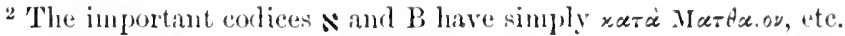

${ }^{3}$ Einleitung, \$9, note. De. Watte observes: "The titles xar $\dot{\text { Mardxion, }}$ ete., fo mot definitely" indiente these men as their authors; but the opinion of all antipuity attests the commmly accepted rense." Einleituny, $\$ 8$. 
the evangelists are always regarded as the direct anthors of their Gospels. The oneness of the Gospels is implied by the use of the preposition instead of the genitive. ${ }^{1}$ There are not, strictly speaking, four Gospels, but one given in four different forms; the Gospel not of, but according to Matthew, the Gospel according to Mark, etc.

The term synoptic is a recent critical designation. As the adjective from Synopsis (which is compounded of $\sigma v^{\prime} \nu$ and $o ̛ \psi \iota s$, parallel to the Latin conspcctus), it denotes that in these Gospels we have a narrative of the life of Christ which may be arranged into sections, so as to afford us a general view or conspectus of His sayings and doings. The term is used to distinguish the first three Gospels from the fourth, which is more concerned with the discourses than with the actions of Christ. It is comparatively modem, ${ }^{2}$ and does not occur in the writings of the Fathers.

The specific difference between the Synoptic Gospels and the Fourth Gospel is obvious. It is not necessary to enter upon it here in detail, as it has already been fully discussed in a former Introduction. ${ }^{3}$ We would only notice four points of difference. 1. They differ in regard to the locality of the events narrated. In the Synoptics the scene of our Lord's ministry is chiefly laid in Galilee. Until the period of His last sufferings there is little mention of Jndiea, and we would hardly have known that $\mathrm{He}$ frequently visited that country. On the other hand, in John's Gospel the scene is chiefly laid in Judra. The visits of Christ to Jerusalem at the great annual feasts, His conversation with the Jews on these occasions, and the miracles which He then performed, form the chief contents of that Gospel; whilst His ministry in Galilee is seldom, and only incidentally, alluded to. ${ }^{5} \quad 2$. They appar-

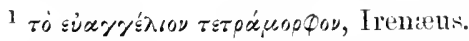

2 According to Archleacom Farrar, it was brought into general use hy Grieshach. See also Holtzmann's Einleitumy, p. 370.

${ }^{3}$ Gloag's Introduction to the Johennine Writings, Pl. 130-147.

${ }^{4}$ Luke ix. 41 would seem to intimate a journey to Jerusalem in the middle of His ministry : it nay, however, allude by anticipation to His last journey.

${ }_{\mathbf{5}}$ Allusions to a Galilean ministry in Joln's Gospel are found in John ii. 12 , vi. $1,4,59$, vii. 1 . 
ently differ as to the duration of Christ's ministry. In the Synoptics our Lord's ministry would seem to be comprised within the short space of one year. There is mention only of one visit to Jerusalem, at the Passover when He suffered; and nothing woukl lead us to suppose that three Passovers oecurred during the comrse of His ministry. Whereas in John's Gospel three Passovers are recorded, ${ }^{1}$ so that His ministry must have extended over two or three years. 3. They differ in the events narrated. There is little in common between the facts and discourses reeorded in the Synoptics and those recorded in the Fourth Gospel. Exchding the narrative of our Lord's last visit to Jerusalem when He suftered, and the narrative of His resurrection, there are only three incidents which John relates in common with the other evangelists - the miraenlous feeding of the multitude, the walking on the Sea of Galilee, and the anointing by Mary the sister of Lazarus. The miraculous birth of Christ, His baptism and temptation, the transfiguration, the institution of the Supper, the agony of Gethsemane, narrated by the Synoptists, are omitted in John's Gospel; whilst the eure of the man who was born blind, the healing of the impotent man at the pool of Bethesda, and the resurrection of Lazarus, mentioned by John, are omitted by the Synoptists. 4. They differ in the eharacter of the teaching or discourses of Jesus. In the Symoptists the discomrses of our Lord are chiefly given in parables: His teaching is brought down to the comprehension of the multitude. On the other hand, in the Fourth Gospel this mode of instruction is entirely awanting, except where there is an approach to it in the allegories of the Good shepherd and of the Vine and its branches: the discourses are for the most part of a subjective and nustical character, relating to the deep things of Gorl. These clitferences have been variously aceounted for, and reasons have been assigned for then; but still they notably exist, and are sufficient to justify the distinction which has been made between the Fourth Gosprel and the other three.

The Fathers have always reconghed only four crospels, manely, the three Symopties, Matthew, Mark, and Luke, and the Fourth Ciospel, that of John. Thus Irenieus, in a well1 Jolm ii. 13, vi. 3, 4, xii. 1. 
known passage, observes: "Since there are four regions of the world in which we live, and four principal winds, and since the Church is spread over all the world, and the gospel is the pillar and ground of the Church, it is fitting that it should have four pillars breathing out immortality and imparting life to men. From which it is evident the Word, the Creator of all men, and who sitteth above the cherubim, and is the Sustainer of all, has given us the gospel under four aspects, but bound together by one Spirit." " We have nothing to do with the fanciful illustrations of Irenæus, but only with the fact which he attests, that there are four Gospels, neither more nor less. These Gospels he afterwards declares to be those of Matthew, Mark, Luke, and John. No other Gospel was admitted anong the sacred books of the early Christians: neither in the writings of the Fathers, nor in the manuscripts of the New Testament, is any other Gospel mentioned as having received the authority and sanction of the Church. Thus Clemens Alexandrinus, when referring to a passage taken from an apocryphal Gospel, says: "We do not find this statement in the four Gospels that have been handed down to us, but in that according to the Egyptians." 2

But although there were only four Gospels received as of any authority by the Church at the close of the second century, namely, those which we now possess, yet numbers of non-canonical Gospels were written and disseminated chiefly in the second century. ${ }^{3}$ Most of them are of no importance, and are full of the nost trivial and extravagant incidents. Three may be mentioned which for certain reasons have attained notoriety, but which, although frequently referred to by the Fathers, were never regarded as of any authority.

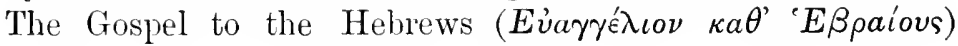
was used by the Ebionites, Nazarenes, and other Jewish-

${ }^{1}$ Irenæus, Adv. Her. iii. 11. 8; Charteris' Canonicity, pp. 68, 69. Dr. Taylor supposes that this statement of Irenæus about the fourfold Gospel was anticipated by Hermas, A.D. 143.

2 Clemens Alexandrinus, Strom. iii. 13.

${ }^{3}$ For a succinct accomnt of the non-canonical Gospels, see Guericke, Isagogik, pp. $225 \mathrm{ft}$; ; De Wette, Einleitung, $\$$ 63-74 ; translation, pp. 87 124; and Baring-Gonld, Lost and Hostile Gospels. 
Christian seets. It appears to have been closely related to the Gospel of Matthew, and will occupy our attention when we come to the special consideration of that Gospel. The Gospel of Marcion, an anti-Judaistic-Gnostic Gospel, constructed by Marcion for the propagation of his opinions, was the subject of much controversy toward the close of the second century, and was fiercely attacked by Tertullian. ${ }^{1}$ It was closely related to the Gospel of Luke, which was mutilated and corrupted by Marcion from dogmatic considerations. ${ }^{2}$ It will also occupy our attention when we consider the third Gospel. The Gospel of Peter, which has recently obtained additional interest from the discovery of an important fragment, and which is especially valuable, as that fragment contains an accomnt of the trial and death of Christ.

The four Gospels, whilst they contain an account of the life and teaching of Christ, record only a small portion of the events of our Lord's life. There must have been uumerous other works done by Christ, and numerous other discourses delivered by Him, which are not recorded; we have at best only selected deeds and discourses narrated. St. John expressly asserts the fragmentary nature of his crospel: "Many other signs therefore did Jesus in the presence of the disciples, which are not written in this book" (John xx. 30 ; comp. John xxi. 25). When we reflect on the fulmess of such a life as that of Jesus, that He must lave been ever actively engaged in His Father's hosiness, and ever teaching the multitude in public and His disciples in private, we eannot but conclude that the accounts which we possess are of a most fragmentary nature. We have, for example, only a few incirlents of the early life of Jesus before He attained to the age of thirty, when He entered upon His ministry. Luke only states one ineident, His converse with the doctors in the temple (Luke ii. $41-51$ ), when He wis about twelve years of age. And after He eommeneed His publie ministry, the Gospels themselves suggest the franmentary nature of their accounts. by eompaning the Fourth

1 Contre Marcion.

2 Irenaeus, Ade. Mur. i. 27. 2 ; 'Tutullian, Contre Marcion, iv. 2. 
Gospel with the Synoptics we see what important events and discourses they have omitted. ${ }^{1}$ In the accounts given us there is also a want of chronological order. ${ }^{2}$ The Synoptists do not follow the same order in the events they record; so that it is extremely difficult, if not impossible, to form a harmony of their accounts.

\section{The Authors of the Synoptic Gospels.}

The authors of the Synoptic Gospels were Matthew, Mark, and Luke; one an apostle, the other two disciples of the apostles. The anthor of the Fourth Gospel was "the beloved disciple." They wrote for different readers, as we shall see when we examine the Gospels seriatim. It has been held that St. Matthew's is the Gospel for the Jews; St. Mark's is the Gospel for the Romans; St. Luke's is the Gospel for the Greeks; St. John's is the Gospel for the universal Church.

These Gospels have been symbolised in accordance with the description of the cherubim in the prophecy of Ezekiel, and of the living creatures in the Apocalypse. In Ezekiel the cherubim are described as having each four faces-the face of a man, a lion, an ox, and an eagle (Ezek. i. 10); whilst in the Apocalypse the living creatures are thus described: "The first creature was like a lion, the second like a calf, the third like a man, the fourth like a flying eagle" (Rev. iv. 7). These symbols were, at a very early period, taken to represent the Gospels, and have been enshrined in Christian art. Irenæus thus explains these evangelical symbols. The first living creature, the lion, the symbol of strength, dominion, and royal power, represents the Gospel of John, relating the glorious generation of Christ from the Father, as the Word by whom all things were made. The second living creature, the ox, the symbol of sacrifice and priesthood, represents the Gospel of Luke, commencing

1 See Alford's Greek Testement, vol. i. Prolegomena, ch. i. § v.; Archbishop Thomson in Speaker's Commentary N.T, vol. i. p. vii f.; Westeott's Introduction to the Study of the Gospels, p. 20.

2 See Eichhorn's Einleitung in eles N.T. $\$ 136$ 
with Zeehariah the priest offering up a saerifice to God. The third living creature, the man, the symbol of humanity, represents the Gospel of Matthew, proclaiming the human birth of Christ, and commencing with His generation as a man. The fourth living creature, the flying eagle, pointing to the gift of the Spirit, hovering with His wings over the Church, represents the Gospel of Mark, testifying to the prophetic Spirit which comes from above by referring to the prophet Isaiah. ${ }^{1}$ So that, according to Irencens, the lion is the symbol of John, the ox of Luke, the man of Matthew, and the eagle of Mark. These symbols are given in a different order by otler Fathers. According to Athmasius, the man denotes Matthew, the ox Mark, the lion Luke, and the eagle John. Augustine assigns the lion to Matthew, the man to Mark, the ox to Luke, and the eagle to John. The symbolism now generally adopted and found in paintings and seulptures is that given us by Jerome. "The first form, that of a man," he olsserves, "denotes Matthew, because he at once begins to write of the man. The form of the lion denotes Mark, the voice of the roaring lion in the wilderness being heard in his Gospel. The third, that of the ox, represents Luke, who begins with the priest Kechariall. The fourth form, that of the eagle, represents John, who soars above as on eagle's wings, and speaks of the divine Word." 2 These analogies are, no donbt, faneiful, and of no importance in themselves, still they bear upon the question as to the number of Gospels regarded as eanonical and authentic.

\section{Genulneness of the Srnoptic Gospels.}

The external and internal evitences acerediting each of these frospels will be exannined when we consider them separately. There we take the symoptic cospels tongether at a whole. We shatl commence with the perion when they were miversally ackowwedged by the Chmreh, and trace the proofs of their existence hackwarls as near to their somee is prossible. Ireniens (A.1), 180) thus mentions the four

I Irenens, Adr. Har. iii. 11. 8; Kirchhofer's Quellensemmlung, 1. 40.

"l'polograte to his Conment. in Ev. Mathei. 
Gospels: "Matthew issued a written Gospel among the Hebrews in their own dialect, while Peter and Paul were preaching at Rome, and laying the foundation of the Church. After their departure, Mark, the disciple and interpreter of Peter, did also hand down to us in writing what had been preached by Peter. Luke also, the companion of Paul, recorded in a book the gospel preached by him. Afterwards John, the disciple of the Lord, who also had leaned upon His breast, did himself publish a Gospel during his residence at Ephesus in Asia." ${ }^{1}$ And we have already mentioned his reference to those four Gospels in assigning to each of them the prophetic symbols. The testimony of Irenæus is very important, as he ministered both in the East in Proconsular Asia, and in the West in Gaul. He was also the disciple of Polycarp, and accordingly only one step removed from the apostles. His testimony is corroborated by his contemporaries, Clemens Alexandrinus and Tertullian. Clemens Alexandrinus (A.I) 190) repeatedly alludes to the four Gospels.' He states that the Gospels containing the genealogies were written first; and that the Gospel of St. John came last, that apostle writing at the instigation of his friends a spiritual Gospel. ${ }^{2}$ In a passage already quoted, he speaks of the four Gospels committed to us. ${ }^{3}$ Tertullian (A.D. 200) is equally explicit: "Of the apostles, John and Matthew instil faith into us, whilst of apostolic men Luke and Mark afterwards renew it." 4

These testimonies are not only of importance as the testimonies of these early Fathers, but as being the testimonies of the Churches which they represented; so that in Asia Minor, in Gaul, in Egypt, and in Roman Africa, we have the assurance that toward the close of the second century the four Gospels which we possess were in circulation, and accepted by the whole Christian Church as authoritative histories of the life of Christ. In the forcible words

${ }^{1}$ Irenæus, Alv. Har. iii. 1. 1 ; Eusebius, Hist. Ect. v. 8.

2 Euseljius, Hist. Eccl. vi. 14.

${ }^{3}$ Clemens Alexandrinus, Strom. iii. 13.

${ }^{4}$ Tertullian, Contra Murcion, iv. 2: Nobis fidem ex apostolis Joannes et Mattheus insinuant, ex apostolicis Lucas et Marcus instaurant. 
of P'rofessor Norton: "About the end of the seeond century the Gospels were reverenced as saered books by a community dispersed over the whole world, composed of men of different nations and languages. There were, to say the least, sixty thousand copies in existence. ${ }^{1}$ They were read in the assemblies of Christians; they were contimually quoted and appealed to, as of the highest authority; their reputation was as well established among believer's from one end of the Roman Empire to the other as it is among Christians at the present day. The general reception of the Gospels as books of the highest anthority at the end of the second century necessarily implies their celebrity at a much earlier period, and the long operation of causes sufficient to produce so remarkable a phenomenon." 2

A remarkable fragment of the so-ealled Gospel of Peter has lately been brought to light. This Crospel, seldom alluded to by the Fathers, is adverted to by Eusebius. ${ }^{3}$ He mentions among the spurions writings ascribed to Peter, "the Gospel which bears his name." ${ }^{4}$ He also informs us that this Gospel is mentioned by Serapion, the bishop of Antioch (A.D. 190), as in use in the ehurch of lihossus in his diocese, and that it was rejected by him on account of the heretical doetrines which it contained. At first the bishop permitted it to be read, beeause, not having seen it, he was ignorant of its erroneous teaching; but this having been brought to his knowledge, he forbade its use: "Having obtained this Gospel from others who have studied it diligently, namely, from the successors of those who first used it, whom we call Docete, we have read it through, and find many things in accordanee with the true doctrine of the

1 Profesisor Norton hases this calculation on the fact that at the end of the second aentury there would be there millions of believers, anxions (1) obtain copres of the (fospels; and supposing one ropy for erely fifty

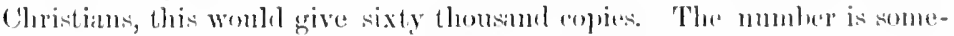
what exagremed, hint it must have been very great. We have very little information as to the cost of hooks in ancient times.

"Norton, The Genmineness of the Gospets, vol. i. 1. 123. See also lilp. 31,32 .

"Mentioned also hy Origen, Ad Mutth. xiii. it.

1 Eusulius, Hist. Eorl. iii. 3. 
Saviour, but some things added to that doctrine which we have pointed out to you further on." 1 In 1886 a fragment was discovered in a tomb near the town of Akhman, the Panopolis of Strabo, in Egypt, containing an account of the sulferings and resurrection of Christ, which has with extreme probability been supposed to be a part of this Gospel. ${ }^{2}$ It completely agrees with the description given by Serapion, being in general accordance with the orthodox doctrine of Christ, but tinged with Docetism; as, for example, it states that when Christ hung upon the cross He was free from pain, and that $\mathrm{He}$ was deserted by the Power at the moment of His death. $^{3}$ The latest date that can be assigned to it is A.D. 170 , having been referred to by Serapion in A.D. 190 ; probably it belongs to the middle of the second century. ${ }^{4}$ Some imagine that it may possibly have been one of the documents referred to by Luke in his Gospel; but this is extremely improbable, as from the nature of its contents it is to be classed among the spurious Gospels. The fragment we possess is taken from our Gospels with several additions. The trial of Jesus is transferred from Pilate to Herod. There are references in it to all the Synoptic Gospels; as, for example, it is stated that Pilate washed his hands, which is mentioned only in Matthew's Gospel; that our Lord was tried before Herod, to which Luke only alludes; and although no incident is recorded peculiar to Mark, yet this is accounted for by the similarity of this Gospel to the other two. In this fragment, then, we have a proof that the Synoptic Gospels were current in the Church before A.D. $170 .^{5}$

${ }^{1}$ Ensebius, Hist. Eccl. vi. 12. See also Jones On the Canon, vol. i. 1p. 284-290.

2 Along with this fragment of the Gospel of Peter were found portions of the Book of Enoch and the Aprocalypse of Peter.

${ }^{3}$ Instead of the evangelic words, "My God, my God, why hast Thou forsaken me?" the Gospel of Peter has, "My power, my power, Thon hast

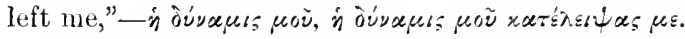

${ }^{4}$ Zahn fixes the date about A.D. 140 or 150 ; Sanday, hardly later than the end of the first quarter of the second century; Harnack, about A.D. 115. It has been smpposed that Justin makes use of this Gospel. Sanday's Bampton Leetures, p. 310.

5 See The Alhman Fragment of the Apocryphal Gospel of St. Peter, by Professor Swete, 1893 ; The Gospel according to Peter, two lectures by J. 
The next testimony to which we advert is the Muratorian Canon. This celebrated and valuable fragment, mutilated both at the beginuing and at the end, was discovered in the Ambrosian Library in Milan, and first published by Muratori in 1740 . It professes to have been written by a contemporary of I'ius, bishop of Rome, and is therefore to be placed abont the year A.D. 160. Its gemnineness has been generally acknowledged. Owing to its mutilation, the first two Gospels are not named; but there is no doubt that the canon recognised the four Gospels, as the Cospel of Luke is mentioned as the third, and the Gospel of John as the fourth; and we may therefore infer that the first and sceond Gospels were mentioned in that part of the canon which is wanting. ${ }^{1}$

Tatian (A.D. 160) is another important witness to the existence of the Synoptic Gospels in the middle of the second century. He was, as he himself informs us, born in the land of Assyria, and was a disciple of Justin Martyr. After the death of Justin he fell into heresy, having adopted the errors of the Encratites, a Gnostic sect of an ascetic nature, related to Mareion." His Diatessaron, or Harmony of the Four Gospels, was his great work, and was probably written before his lapse into heresy." Eusebius informs us that "Tatian composed a certain combination and collection of the Cospels, to which he gave the name Diatessaron, and which is current

Armitage Rolinson and M. R. James; Bruhstiocke des Evongelium und der A poculypse des Petrus, hy Harnack, 1893 ; Des Exungelium des I'etrus, ly Zahn, 1893; Gebhart, Dess Erenyelium und die Apoculypse Petrus; Sichubert, Die Compusition der pseudopetrinischen Evengelien-Framente; 1)r. Salmon's (of Inulin) Iutroduction to the N.T., Tth aditiom, Alpendix, Note III., 'The (rospel of Peter, [']' 581-589; The Nerly-llixcorered Gospel of St. Peter, ly .l. Resudel llarris, 1893.

1 The fullest aceount of the Muratorian eanon is given ly Tregelles in his "Conon. Muretorientes, the earliest catalogne of the husk of the New Testament, edited with notes, and a facsinile of the MS. in the Ambrosian Jibrary at Milan." A transerije of it is given hy Kirchlofur in his (buellen-

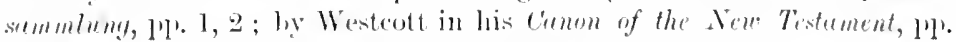

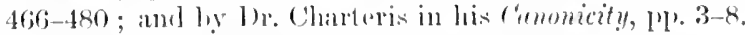

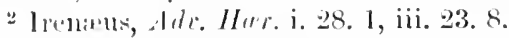

"Besides the Diatessirom, Tat ian wrote an "Aldhess to the (irecks,"

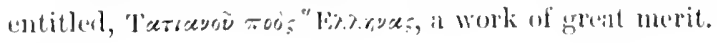


with some persons even in the present day." ${ }^{1}$ And Epiphanins says: "The Diatessaron Gospel is said to have been composed by Tatian.".2 This harmony of the Gospels was in great repute in the fifth eentury among the Syrian Churehes. Theodoret, bishop of Cyrrhus (A.D. 420), informs us that "Tatian composed the Gospel which is called the Diatessaron, omitting the genealogies and whatever other passages show that our Lord was born of the seed of David according to the flesh;" and he tells us that in his diocese there were more than two hundred copies of it. ${ }^{3}$ Dionysins Bar-Salibi, an Armenian bishop of the twelfth century, informs us that Ephriem Syrus (A.D. 370) wrote a commentary upon it. ${ }^{4}$ Its existence was called in question, and it was asserted that Tatian's Diatessaron was not a harmony of the four Gospels, but was to be ranked among the uncanonised or spurious Gospels. ${ }^{5}$ This assertion has been recently proved to be unfounded. The commentary of Ephrem Syrus has been discovered in an Armenian version in the Armenian convent near Venice, in two manuscripts, bearing the date A.D. 1195, and agreeing with what we know of Tatian's harmony; and a Latin translation of it by Aucher, one of the Armenian monks, was corrected and published by Mœsinger in $1876 .^{6}$ But more recently still two manuscripts have been discovered by Professor Agostino Ciasca, the one in the Vatican and the other in the Borgian Museum, containing Arabic translations of the Diatessaron itself. ${ }^{7}$ A note attached

1 Eusebins, Hist. Eccl. iv. 29.

2 Epiplanins, Her. xlvi. 1.

3 Theodoret, $H_{w}$. Fub. i. 20, ii. $158 \mathrm{ff}$. Theodoret regarded the Diatessaron with prejudice. He sars that he collected and put away all the copies and substituted the Gospels of the four evangelists in their stead. He is mistaken in asserting that Tatian purposely omitted passages which referred to Christ being born of the seed of David.

${ }^{4}$ Assemanni, Biblivth. Orient. ii. 1'. $158 \mathrm{ff}$.

${ }^{5}$ Supernatural Religion, vol. ii. 1. 152 ff.

${ }^{6}$ Evangelii concordantis expositio facta a Sancto Ephræmo Doctore Syro. In Latinum translata a J. B. Ancher. Ediclit Mcesinger. Venetiis, 1876. See on the discovery of Ephrem's commentary on Tatiau's Diatessaron two interesting articles by Professor Wace in the Expositor for 1882, and Zahn's Tatian's Diatessaron, p. $240 \mathrm{ff}$.

'At the end of the Vatican MSS. is written: "Here endeth by the hell" of God the sacred Gospel which Tatian collected out of the fonr Gospels, 
to each asserts that it is Tatian's Diatessaron. A translation was published by Ciasca in 1888 , based upon the two Arabie manuseripts, acempanied by introductory explanations. ${ }^{1}$ An English translation has been made by the Rev. .J. Hamlyn Hill (1894), with an important introcluction and several appendices. ${ }^{2}$ It has also been prover that the Codex Fuldensis, a latin version of the New Testament belonging to the sixth century in the form of a harmony, is probably based on the Diatessaron. ${ }^{3}$ The importance of this discovery is very great. There is no doubt whatever that we have here mannscripts of the translation of the Diatessaron; and accordingly it is now demonstrated that Tatian composed a harmony of the four canonical Gospels. ${ }^{4}$ He used our Gospels only : there is no trace of any non-canonical Gospels. The difference is but slight between it and our Gospels: there are few additions and omissions. The most important omissions are the genealogies of the Gospels of Matthew and Luke, as Theodoret testifies, and as is found to be the case in the Borgian Arabic manuscript. ${ }^{5}$ It is very valuable as a harmony, and, indeed, can bear a comparison with recent harmonies. ${ }^{6}$ It is not improbable that the Diatessaron was written, as Professor Zahn surmises, in Syriac, and that the version which was employed was the Curetonian version. ${ }^{7}$ This will account for and which is commonly called the Diatessaron"; and at the beginning of the Borgian MSS. "With the assistance of the Most High God we begin to translate the holy Gowpel entitled the Diatessaron, which Tatian, a Greek, compiled out of the four Gonpets."

1 Tutiuni Erangeliorum Harmonice Arabice, 1888.

2 "The errliest life of Christ ever compiled from the Four Gospels, being the Dintessaron of T'utian, literally transcribed from the Arabic I'ersion, and contuining the Four Gospels woven in one story," by the Rev. J. Hamlyn Hill. Edinburgh: T. \& 'T'. Clark, 1894. The tranklation is from the Latin translation of the Aralic versions by Ciasea complared with the Arabie.

3 See article by H. Wiace in Expositor for 1881.

4 See Rendel Harris' Diutesseron of Tutien; Hemphill's Diatessaron.

5 The Vatican MS. contains the genealogies, bnt in the Borgian Ms. they are absent from the body of the work, and are inserted in an Appendix.

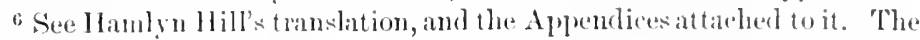
valriations between the Diatessuron and the (iospels ane wonderfully small.

${ }^{7}$ Zilhn's Trutiun's Dietesseron, l'l. 18, 22:9. Zilhn, before the liscovery of the Aralic MS'sis, attempted a reconstruction of 'Tittimn's works, chiefly. from Liphriem's commentary. 
the comparative ignorance of it in the Latin and Greek Churehes, and for its use in the Syriac Churches. It was looked upon with suspicion by the early Fathers, on account of the heretical views of the author. ${ }^{1}$

Next in order is the important testimony of Justin Martyr (A.D. 150). The extant works of Justin consist of two Apologies and a dialogue with Trypho the Jew. The Apologies were addressed to Antoninus Pins, and are assigned to the middle of the second century. In them he speaks frequently of the Memoirs or Memorabilia of the Apostles. The Gospels are not named, but there are various quotations from them; and the incidents of our Lord's life mentioned by Justin are in accordance with them. It is true that in the quotations the precise words are not given; Justin appears to have quoted from memory; but that is also the case with his quotations from the Old Testament. Justin informs us that the Memoirs of the Apostles were read publicly in the churches, and were regarded with as much reverence as the writings of the prophets. The quotations and references to our Gospels are exceedingly numerous; and whatever dubiety there may be as regards St. John's Gospel, there is no donbt whatever that the Synoptic Gospels are repeatedly quoted. Thus Matthew is directly quoted in these words: "Christ when on earth told those who said that Elias would come before Christ, Elias will indeed come and restore all things; but I say unto you that Elias came already, and they knew him not, but did to him all that they listed. And it is written, Then molerstood the disciples that He spoke to them of John the Baptist" ${ }^{3}$ (Matt. xvii. 13); Mark is directly quoted in the following words: "It is said that He changed the name of one of the apostles to Peter; and it is written in the Memoirs of Him that He changed the name of other two brothers, the sons of

1 See an elaborate article on 'Tatian by Professor Fuller of King's College, London, in Sinith's Dictionary of Bioyraphy, and another by Miiller in Herzog's Real-Encyclopädlie, vol. xv. pp. $208 \mathrm{fl}$.

2 That Justin used the Gospel of John is now generally admitted. See Ezra Albbot's work on the Authorship of the Fourth Gospel.

${ }^{3}$ Dial. ch. xhix. 
Zebedee, to Boanerges, which means the sons of thunder" 1 (Mark iii. 16, 17); and Luke is directly quoted in these words: "For when Christ was giving up His spirit on the cross, He said, Father, into Thy hands I commend My spirit, as I have learned from the Memoirs"2 (Luke xxiii. 46). It is true that there are one or two incidents mentioned by Justin which are not recorded in our Gospels, and which lave given rise to the assertion that Justin did not qnote from the Synopties, but from some uncanonical Gospel. ${ }^{3}$ Thus Justin says that "Christ being regarded as a worker in wood, did make while among men plonghs and yokes, thus setting before them symbols of righteonsness, and teaching them an active life;" 4 and that "when Jesus came to Jordan, where John was baptizing, upon His entering the water a fire was kindled in the Jordan." 5 But these extra-canonical incidents are few, and may be accounted for either as inferences which Justin drew from the statements of the evangelists, or as traditions of the life of Jesus which at that early period survived in the Chureh. As Paley remarks: "In all Justin's works, from which might be extracted almost a complete life of Christ, there are but two instances in which he refers to anything as said or done by Christ which is not related concerning Him in the present Gospels; which shows that these Gospels, and these alone, were the anthorities from which the Christians of that day drew the information on which they depended." "

We now come to the important and much eontroverted statement of Papias (A.1). 120). Papias, bishop of Hierapolis in Phrygia, may well be regarded as an apostolic Father, as lhe was either, along with I'olycarly, a diseiple of the Apostle John, or a disciple of John the I'reslyter. ${ }^{7}$ He

1 Jial. ch. cvi. 2 Diul. ch. "v.

"Thus De Wette mentions among the mncanonical Gospels the Gospel of Justin, şง 6 f6, 6 it.

1 Jial. cum Tryph. ch. 1xxxviii. "Item.

"Paley's Evidences of Christianity, pt. i. ch. ix.\$1.

7 Irenæus, Adr. Iter. v. 33. 4.

${ }^{8}$ Eusebius, Ilist. Eict. iii. 39. It is a question whether John the Presbyter ever existed, or whether this is merely another name for 
professes to have conversed with those who were intimate with several of the apostles. He was a voluminous writer, his chief work being an exposition of the discourses of our Lord ( $\lambda o \gamma i \omega \nu$

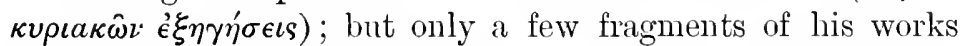
remain preserved by Eusebius. ${ }^{1}$ We have the following important testimony to the Gospels of Matthew and Mark: "John the Presbyter also said, Mark having become the interpreter of Peter, wrote down accurately, though not indeed in order, whatsoever he remembered of the things said or done by Christ. For he neither heard the Lord nor followed Him; but afterward, as is said, he followed Peter, who adapted his teaching to the needs of his hearers, but with no intention of giving a connected account of the Lord's discourses, so that Mark committed no error, while he thus wrote some things as he remembered them. For he was careful of one thing, not to omit any of the things which he had heard, and not to state any of them falsely. These things are related by Papias concerning Mark Concerning Matthew he writes as follows: Matthew composed his dis-

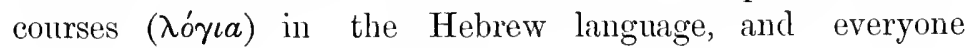
interpreted them as he was able." 2 This statement will, in the course of our Introduction, frequently occupy our attention; much has been made of it in the question regarding the origin of the Synoptic Gospels. It proves

John the apostle. Gloag's Introduction to the Johannine Writings, pp. 268-270.

${ }^{1}$ On the fragments from Papias, see Holtzmann's Synopt. Evangel. pp. 248 ff.; Weizsäeker, Untersuch. über d. cvany. Geschichte; Steitz in Herzog's Encykl. 1st ed. vol. xi. pre. 79 f.

2 Eusebius, Hist. Eccl. iii. 39. The words of Papias are so very important, and will he so often referred to, that we give this quotation

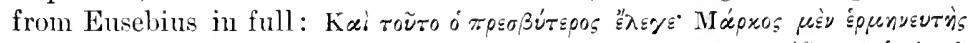

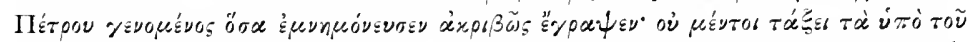

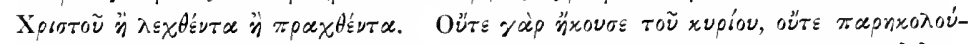

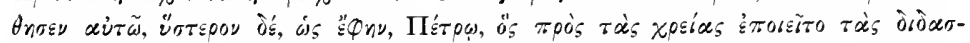

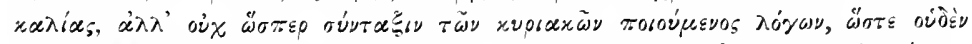

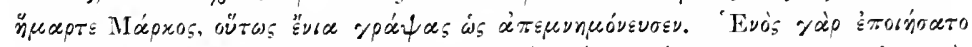

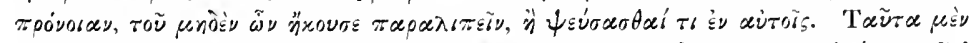

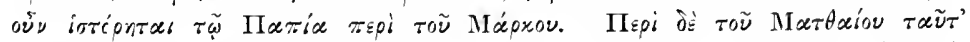

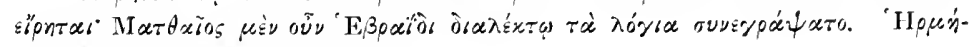

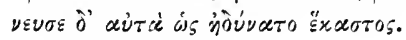


that in the time of Papias writings did exist which bore the names of the first two evangelists, Matthew and Mark. ${ }^{1}$

We do not carry our investigation further back. In the writings of the apostolic Fathers there are allusions more or less distinct to the Synoptic Gospels, and especially in the Didache there is a distinct correspondence to the Sermon on the Monnt; but as such evidence relates to particular Gospels rather than to the Synoptic Gospels collectively, it will be considered in its proper place.

Besides these quotations from the Fathers, there is also the evidenee derived from the ancient versions, especially the old Latin and the Syriac. The old Latin (Vetes Latina) must have existed about A.J. 170, because it is quoted and used by Tertullian and in the Latin translation of Irenceus. It was made, not for the use of the Church of Rome, which was at first Greek, but for the Christians in the Roman province of Africa, of which Carthage was the eapital. All the manuscripts contain the four Gospels. The Syriac is probably the earliest version, as it would be the first required; and the probability is that Tatian made use of it in the eomposition of his Diatessaron. There are good reasons for fixing its date about the middle of the second century (A.1). 150). ${ }^{2} \quad$ Although some of the books of Scripture are omitted, yet in all the syriac manuscripts the four Gospels are fouml. Some suppose that the Peshito, the wellknown Syriac version, is not the original form of the syriac, but a revised version from an older form, of which the

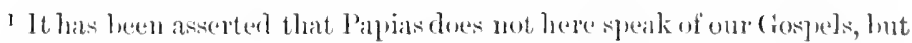

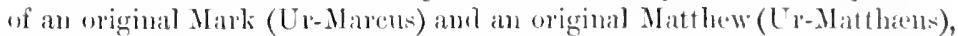
from which omr Gospels were derived; or else he mentions two distinct doemments, "the teaching of Peter," as givel ly Mark, and "the logia of Matthew," which formed the chief someres of the Synoptic (roppels. These opinions will afterwards form the sulpeet of dischssion. Others

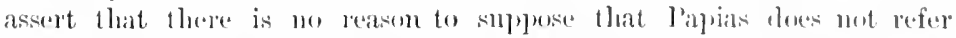

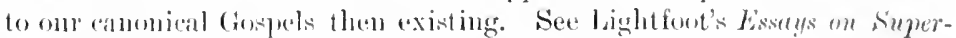

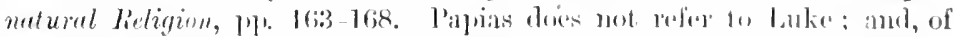

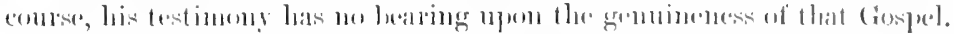

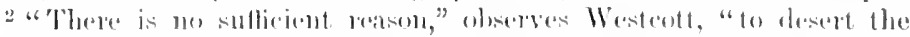

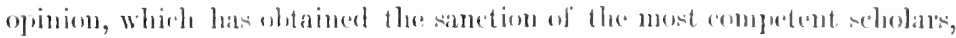
that its formation is to he fixed within ale first half of the second century." Winteott, "1n the Cemon, 1, 211. 
Curetonian manuscript is a fragment; and that the Peshito bears the same relation to the ancient Syriac as the Vulgate does to the old Latin. ${ }^{1}$

Such is the evidence for the genuineness of the Synoptic Gospels as a whole. No classical writing of the ancients has the same amount of testimony. When we consider the universal acceptance of these Gospels toward the close of the second century, the reverence shown to them as sacred books, their wide distribution throughout all the provinces of the Roman Empire, the explicit testimony of Justin Martyr to them in the middle of that century, their translation into the Latin and Syriac languages, we cannot fail to be convinced that they are the genuine records of the life of Christ. The hypothesis that they were inventions is inadmissible in regard to documents written so soon after the events they purport to record, and they were of an importance too vital to those to whom they were addressed, to be received on insufficient evidence. The theory of Strauss, that the Gospels contain myths and legends, which half a century ago made such a noise, and was regarded as a formidable objection, is now generally discarded as utterly baseless; the time between the events recorded and the publication of these Gospels is too short to admit of such a prolific growth of legends or myths. $^{2}$ And so, also, the more acute and ingenious theory of Baur, that the Gospels and other books of Scripture were written with a tendency-design, either as statements of Pauline or of Petrine Christianity, or with a view to mediate between two antagonistic systems, has now few adherents. ${ }^{3}$ Hilgenfeld and Holsten, and perhaps we may also include Pfleiderer, are almost the only real representatives of the Tübingen school, and yet their opinions differ materially from

${ }^{1}$ See on this point Westcott and Hort's Greek Testament, vol. ii. p. 84. The Syriac version, found hy Mrs. Lewis in 1893 in the monastery of St. Catherine at Mount Sinai, is supposed to be a variation of the Curetonian version.

2 Row's Jesus of the Evanyelists, ch. xvi.; Fairbairn's Christ of Modern History, pp. 232-242.

3 According to Baur, Matthew contained Petrine and Luke Pauline Christianity; whilst Mark was conciliatory, and John contained the full reconciliation of Petrine and Pauline Christianity in the Catholic Church. 
those of Baur. Even according to their own admission such tendeney-designs are hardly recognisable in the Synoptic Gospels; because, before these Gospels were written, the antagonisn of Pauline and Petrine Christianity had been smoothed down, and the Gospels were composed chiefly with a coneiliatory design. In short, we are led from all evidence, external as well as internal, to accept the Synoptic Gospels as credible records of the deeds and words of Christ. ${ }^{1}$ There are certainly great, perhaps insoluble, difficulties connected with their origin; but these, as we shall afterwards see, are not sufficient to shake our confidence in the credibility of the history.

\section{Relation of the Synoptic Gospels to eachi other.}

Until recent times it has been generally supposed that the three Synoptic Gospels were wholly independent narratives; that the evangelists, Matthew, Mark, and Luke, infallibly guided by the Spirit of God, each made a selection of the incidents of our Lord's life and of His discourses, without having seen the writings of the other two, or without having recourse to any common oral tradition or written document. Such an opinion, however, has not been confirmed by an examination of their contents. A perusal of the harmony of these Gospels, whether drawn up in English or in Greek, and especially an attentive consideration of the coincidences between them, both in the events recorded and in the language employed, must convinee every unprejudiced reader that common materials must have heen used in their construction, that absolute independence is by the facts of the case excluder, and that to a linge extent there was a

I "We ought," observes Holtzmimm, "at least with regarl to the Syoptic Gospels, to maintain lefinitely that they contain as theis kernel nothing else than the genuine, and in the chiof fertures chemly recognis-

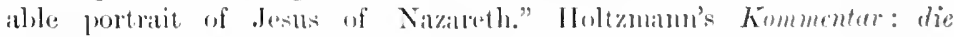

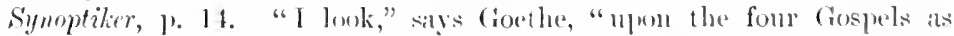
theroughly gromine; for there is in them a reflection of a greatness Which emanated fom the persom of Jests, and which was of ats clivine a kind as "rer" was seen upon "arth." Comersutions of fowthe with Eckermann, p. 567. Bohn inlition. 
source or sources common to all three. But, along with these coincidences, there are points of difference, especially in the Gospels of Matthew and Luke, which prove that the writers of these two Gospels must on these points have drawn their information from different sources. The Synoptic problem-which is the great question at present in the criticism of the New Testament-has to take account of these coincidences and differences, and to explain them by reference to the source or sources of the Gospels themselves. It is proved that there is a dependence between them, and the question is, What is the original basis of this dependence? But before we attempt to answer this question, and to consider the different theories that have been advanced, or to suggest any probable solution, it is essential that we should understand the conditions of the problem.

1. Points of agreement. - The Synoptic Gospels agree as to the locality of our Lord's ministry. They narrate chiefly the ministry in Galilee, omitting the ministry in Judaea, until the period of our Lord's passion; they are all Galilean Gospels; the references to the earlier Judrean ministry are only indirect and inferential. They agree as to the duration of the ministry. There is only mention of one Passover, that at which our Lord suffered; and, were it not for the information afforded in John's Gospel, we might be led to infer that our Lord's ministry did not extend beyond one year. They agree as to the ordcr of the ministry. Although there is a considerable variation in the chronological order of particular incidents, yet the general order, in its main features, is the same. In their accounts of Christ's public ministry they all commence with the preaching of the Baptist and the baptism and temptation of Christ, relate the ministry of Galilee in a somewhat similar order, mention the great crises that occurred in the middle of that ministry, - the confession of the Messiahship of Jesus by the disciples, and the Transfiguration,-and close their narratives by an account of our Lord's death and resurrection. They agree, to a large extent, in the incidents recordcd. Although the works and discourses of Jesus must have been far more numerous than those related, as the Gospel of John proves, yet more than a half of the incidents 
mentioned in the Synoptics are the same in all three. "If," observes Holtzmann, "Jesus doubtless delivered unrecorded sayings, how is it that the narrators have limited themselves to the same selection? If Jesus healed so many sick, why do all three record almost only the same examples? If $\mathrm{He}$ pronomees a woe on Chorazin and Bethsaida, as Matthew and Luke record, how is it that neither of these evangelists mention the conduct which merited such a denunciation?"1

But there is not merely a similarity in the selection of incidents and discourses, but what is even more remarkable, there is a similarity in the language in which these incidents and discourses are expressed. In the examination of this point we are greatly assisted by Rushbrooke's Synopticon, a work of immense labour and ntility. ${ }^{2}$

1. The threfold narrative.-As already observed, there is a remarkable sameness in the incidents recorded by all the three Symoptists. The following sections are common to all three :- -

Ministry of the Baptist, Matt. iii. 1-12; Mark i. 2-8; Luke iii. 1-18.

Baptism of Christ, Matt. iii. 13-17; Mark i. 9-11; Luke iii. 21, 22.

Temptation of Christ, Matt. iv. 1-11; Mark i. 12, 13 ; Luke iv. $1-13$.

Call of the four apostles, Matt. iv. 18-22; Mark i. 16-19; Luke v. 1, 2, 9-11.

${ }^{1}$ Holtzmann's Einleitung, 1. 331. See also Salmon's Introluction to the N.T. 1). 139: "The Synoptic Gospels," lue ohserves, "agree in the main in their selection of facts-all travelling over nearly the same ground, though independent narrators would les sure to have differend a good deal in their clobie of suljects for narration ont of at pullic lifo of three years. In point of fart, we find exartly suell a diflepence betwern

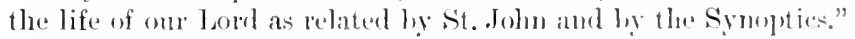

2 Synopticon, an expmition of the eommon matter of the syneptic Gospels, ly W. G. Rumblowke, Follow of St. John's Collegre, Cambielge. London: Dambillan \& (o., 1887. Rushlorooke first gives us what ha calls

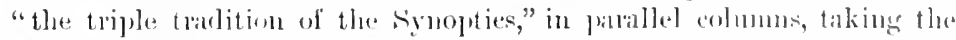

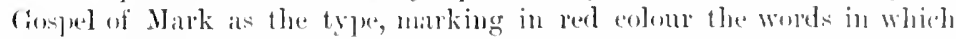
all three agree ; and then in an appendix the twofold edition of Matthew and Luke, with distinctive tyens making their agreements and differences, and lastly, the single tratition of Matthew and Luke. 
Cure of Peter's mother-in-law, Matt. viii. 14-17; Mark i. 29-34; Luke iv. 38-43.

Cleansing of the leper, Matt. viii. 1-4; Mark i. 40-45; Luke v. 12-16.

Cure of the paralytie man, Matt. ix. 1-S ; Mark ii. 1-12; Luke v. $17-26$.

Call of Matthew, Matt. ix. 9-17; Mark ii. 13-22; Luke v. $27-39$.

Our Lord's discourse on the Sabbath, Matt. xii. 1- 8 ; Mark ii. 23-2S; Luke vi. 1-5.

Cure of the man with the withered hand, Matt. xii. 9-15; Mark iii. 1-6; Luke vi. 6-11.

Confutation of the statement that Christ cast out devils through Beelzebub, Matt. xii. 22-45; Mark iii. 20-30; Luke xi. 14-23.

Parable of the Sower, Matt. xiii. 1-23; Mark iv. 1-20; Luke viii. $4-15$.

Stilling of the tempest, Matt. viii. 1S-27; Mark iv. 35-41; Luke viii. $22-25$.

Cure of the Gadarene demoniac, Matt. viii. 2S-34; Mark v. 1-20; Luke viii. 26-39.

Raising of the daughter of .Jairus, Matt. ix. 18-26; Mark v. 21-43; Luke viii. 40-56.

Mission of the twelve, Matt. x. 1-15; Mark vi. 7-13; Luke ix. 1-6.

Feeding of the five thousand, Matt. xiv. 13-21; Mark vi. 31-44; Luke ix. 10-17.

Confession of the apostles that Jesus is the Messiah, Matt. xvi. 13-28; Mark viii. 27-33; Luke ix. 18-27.

The transfiguration, Matt. xvii. 1-10; Mark ix. 2-9; Luke ix. 28-36.

Cure of the demoniae boy, Matt. xvii. 14-21; Mark ix. 14-29; Luke ix. 37-4:3.

Dispute among the disciples eoncerning preeedenee, Matt. xviii. 1-5; Mark ix. 33-37; Luke ix. 46-48.

Blessing pronounced on children, Matt. xix. 13-15; Mark x. 13-16; Luke xviii. 15-17.

Our Lord's address to the rich ruler, Matt. xix. 16-30; Mark x. 17-31; Luke xviii. 18-30. 
Cure of the blind man at Jericho, Matt. xx. 29-34; Mark x. $46-52$; Luke xviii. 35-4:3.

Entrance into Jerusalen, Matt. xxi. 1-11; Mark xi. 1-11; Luke xix. 29-44.

Expulsion of the buyers and sollers from the temple, Matt. xxi. 12-14; Mark xi. 15-17; Luke xix. 45, 46.

Parable of the Vineyard, Matt. xxi. 33-46; Mark xii. 1-12; Luke xx. 9-19.

Refutation of the Sadducees, Matt. xxii. 15-3:3; Mark xii. 18-34; Luke xx. 20-40.

Our Lord's appeal to Ps. cx., Matt. xxii. 41-46; Mark xii. :35-37; Luke xx. 41-45.

Prediction of the destruction of Jerusalem, Matt. xxiv. 1-36; Mark xiii. 1-36; Luke xxi. 5-36.

Institution of the supper, Matt. xxvi. 17-29; Mark xiv. $17-26$; Luke xxii. 14-23.

The agony in Gethsemane, Matt. xxvi. 30-46; Mark xiv. 26-42; Luke xxii. 39-46.

Arrest of Christ, Matt. xxvi. 47-58; Mark xiv. 43-54; Luke xxii. $47-58$.

Denial of Peter, Matt. xxvi. 69-73; Mark xiv. 66-72; Luke xxii. 54-62.

Narrative of the Passion, Matt. xxvii.; Mark xv.; Luke xxiii.

Narrative of the Resurrection, Matt. xxviii.; Mark xvi.; Luke xxiv.

In the narration of these incidents there is frequently a close illentity of language. We give two examples in the words of the Revised Version, in which the nature of the resemblance may he as elearly seen as in the (ireek. The first example is the words spoken by Jesus to the Pharisees when He cured the paralytic man.

MATт. ix. 4-8.

Wherefore think ye evil in your hearts? For whether is easier, to say, Thy sins are forgiven; or to say, Arise, and walk? But that ye may know that the Son of Min hath power on earth

\section{MARK ii. $8-11$.}

Why reason ye these things in your hearts? Whether is easicr, to say to the sich of the palsy, Thy sins are forgiven: or to saly, Arise, anul take up thy hed, and walk? liut that ye mity

\section{Likk v. 22-26.}

What leason ye in your liearts? Whether is easier, to say, Thy sins are formiven thee; or to say, Arise, and walk? But that ye may know that the Son of Man hath power on earth 
to forgive sins (then saith He to the siek of the palsy), Arise, and take "u, thy bed, and go nuto thy honse. know that the Son of Man hatl power on earth to forgive sins (He saith to the siek of the palsy), I say minto thee, Arise, take up thy bed, and go unto thy house. to forgive sins (He said unto him that was palsied), I say unto thee, Arise, and take up thy coneh, and go unto thy honse.

The other example is taken from our Lord's prophecy concerning the destruction of Jerusalem.

Matt. xxiv. 32-35.

Now from the fig tree learn her parable: when herbranch is now become tender, and putteth forth its leaves, ye know that summer is nigh; even so ye also, when ye see all these things, know ye that He is nigh, even at the doors. Verily I say unto you, This generation shall not pass away, till all these things be aceomplished. Heaven and earth shall pass away: but my words shall not pass away.
Mark xiii. 28-31.

Now from the fig tree learn her parable: when her branch is now become tender, and putteth forth its leaves, ye know that summer is nigh ; even so ye also, when ye see these things coming to pass, know ye that $\mathrm{He}$ is nigh, even at the doors. Verily I say unto you, This generation shall not pass away, mitil all these things be aecomplished. Heaven and earth shall pass away: but my words shall not pass away.
LUKE xxi. 29-33.

Behold the fig tree, and all the trees: whell they now shoot forth, ye see it and know of your own selves that the summer is now nigh. Even so ye also, when ye see these things eoming to pass, know ye that the kingrlom of God is night. Verily I say unto you, This generation shall not pass away, till all things be aceomplished. Heaven and earth shall pass away: but my words shall not pass away.

But these passages are only examples of a similarity of language, approaching to identity, which pervades the accounts of the three evangelists. Numerous other examples might be given: as the call of Matthew (Matt. ix. 9-17; Mark ii. 13-22; Luke v. 27-39), the parable of the Sower (Matt. xiii. 1-34; Mark iv. 1-34; Luke viii. 4-18), the stilling of the storm and the cure of the Gadarene demoniac (Matt. viii. 18-34; Mark iv. 35-41, v. 1-20; Luke viii. 22-39), the feeding of the four thousand (Matt. xiv. 13-21; Mark vi. 30-44; Luke ix. 10-17), the transfiguration and the cure of the demoniac boy (Matt. xvii. 1-21; Mark ix. 2-8, 14-29; Luke ix. 28-43), and the entrance into Jerusalem (Matt. xxi. 1-11; Mark xi. 1-10; Luke xix. 29-44).

Such similarities, not merely of incident but of expression, with only slight variations, would in other writings demon- 
strate an inherent dependence. ${ }^{1}$ If we heard three discourses which although in some respects dissimilar, yet were interwoven with passages alnost identical, we would rightly infer that in these passages the preachers copied from each other, or that they plagiarised from the same discomse. If, in the writings of the Fathers, we found passiges ahnost identical with those contained in the Epistles of St. Panl, we should be justified in inferring that there was a distinct reference to the writings of that apostle. Three eye-witnesses in recording the same facts, if their reports were independent of each other, would not express themselves in the same words. And the case is still stronger if the general opinion be correct, that our Lord spoke, not in Greek, but in Aramaic," and that consequently the words of His discourses given us by the evangelists are translations; and it is highly improbable that in translating they would use precisely the same words. We are then constrained to adopt one or other of three suppositions: either that the evangelists copied from each other; or that they all had recourse to some common document; or that there was an oral or traditional Gospel-a collection of the sayings of Christ and of the incidents in His life which had in many points become stereotyped. These suppositions are reserved for after consideration.

The twofoldnarrative. - But there is not only a threefold narrative,-an agreement of all three evangelists in the ineidents recorded, and often almost an identity of language,-but there is a twofold nimrative, where two of the evangelists agreeMatthew and Mark, Mark and Luke, and Mattlew and Luke.

The prineipal ineidents and diseourses common to Matthew and Mark and not fomol in Luke are:-

The mode of the Baytist's martyrdom, Matt. xiv. 1-12; Mark vi. $14-29$.

Our Lord's walking on the water, Matt. xiv. 22-33; Mark vi. $45-51$.

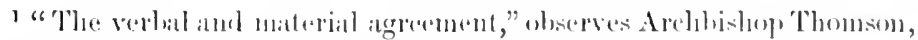

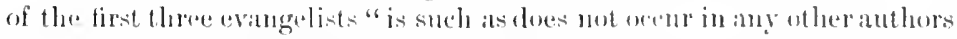
who have writum indepentently of one :mothere."

2 The ordinary langnage of onr Lord and IIis apostles will afterwats form the subject of discussions. 
The discourse on the traditions of the elders, Matt. xv. 1-20; Mark vii. 1-23.

The cure of the daughter of the Syro-Phœnician woman, Matt. xv. 21-28; Mark vii. 24-30.

Feeding of the four thousand, Matt. xv. 32-38; Mark viii. $1-9$.

Discussion on the Mosaic law concerning divorce, Matt. xix. 3-10; Mark x. 2-11.

Petition of the sons of Zebedee and their mother, Matt. xx. 20-2s; Mark x. 35-45.

The withering of the fig tree, Matt. xxi. 18-22; Mark xi. $13,14,20$.

The anointing of our Lord before His passion, ${ }^{1}$ Matt. xxvi. 6-13; Mark xiv. 3-9.

The utterance of Jesus on the cross, My God, my God, why hast Thou forsaken me? Matt. xxvii. 46-49; Mark xv. 34,35 .

Here also there is often a close identity of language. We take as an example the anointing of our Lord before His passion, an incident which is also recorded, but in very different language, by St. John.

Matт. xxvi. 6-13.

Now when Jesus was in Bethany, in the house of Simon the leper, there eame unto Hin a woman having an alabaster eruse of exceeding preeious ointment, and she poured it upon His head, as He sat at meat. But when the disciples saw it, they had indigna. tion, saying, To what purpose is this waste? For this ointment might have been sold for much, and given to the loor. But Jesus prerceiving it, said unto them, Why trouble ye the woman? for she hath wrought a good work upon me. For ye have the poor ahways with you ; but ne ye have not always. For in that she poured this ointment upon my body, sle did it to prepare me for burial. Verily I say
MARK Xiv. 3-19.

And while He was in Bethany, in the house of simon the leper, as He sat at meat, there came a woman having an alabaster eruse of ointment of spikenard very costly; and she brake the cruse, and poured it over His hearl. But there were some that harl indignation anong themselves, saying, To what purpose hath this waste of the ointment been made? For this ointment might have been sold for above three hundred pence, and given to the joor. And they murnured against her. But Jesus said, Let her alone; why trouble ye her? she hath wrought a good work on me. For ye have the joor always with you, and whensoever ye will ye can do them

1 We consider this anointing different from that by the sinful woman mentioned in Luke's Gospel. 
unto you, Wheresoever this gospel shall be preached in the whole world, that also whieh this woman hath done shatl be spoken of for a memorial of her. good: but me ye have not always. She hath done what she could; she hath anointed nuy body aforehand for the burying. And verily I say unto you, Wheresoever the gospel shall be preached throughout the whole world, that also which this woman hath done shall be spoken of for a memorial of her.

This example is perhaps not so convincing an argument in favour of a common souree, as it is just possible that two witnesses might have expressed themselves in terms somewhat similar; but compare with it the narrative in St. John's Gospel, where the difference is much more marked.

The incidents common to Mark and Luke, but omitted by Matthew, are not numerous. They are as follows-

The casting out of an mnelean spirit, Mark i. 23-28; Luke iv. $33-37$.

Declaration of our Lord that He must preach the gospel in other places, Mark i. 35-38; Luke iv. $42,43$.

The apostles forbidding a man to cast out devils in Christ's name, Mark ix. 38-40; Luke ix. 49, 50.

The incident of the widow's mite, Mark xii. 41-44; Luke xxi. $1-4$.

We take this last as an example of identity of langnage-

MARK xii. $43,44$.

Verily I say unto you, This poor widow cast in more than all they which are casting into the treasury: for they all did cast in of their superfluity; but she of her wint dill east in all that she had, cren all her living.
Lukexis. 3, 4.

Of a truth I say unto you, This poor willow cast in mole than they all : for all these disl of their superfhuity cast in unto the gifts: but she of her want did cast in all the living that she hal.

The coincidences in the twofold namative of Matthew and Luke are still more remarkiable. These two evangelists agree in recording the following particulars:-

Adclress of the baptist to the seribes and Pharisees, Matt. iii. $8-10$ : Luke iii. $\&, 9$.

Threefold temptition of our Lord, Matt. iv. 1-11; Luke iv. $1-13$.

Cure of the centurion's servant, Matt. viii. 5-13: Luke vii. $1-10$. 
Our Lord's audress to those who professed a desire to follow Him, Matt. viii. 19-22; Luke ix. 57-60.

His exhortations to His disciples, Matt. x. 5-16, 24-26: Luke x. 1-12, xii. 2-9, 51-53.

Mission of the diseiples of the Baptist to Christ, Matt. xi. 2-19; Luke vii. $18-35$.

The woe pronounced on the cities of Galilee, Matt. xi. 20-24; Luke x. 12-15.

The gospel hid from the wise and prudent, Matt. xi. $25-27$; Luke x. 21, 22 .

Our Lord's answer to the Pharisees when they asked of Him a sign from heaven, Matt. xii. 38-45; Luke xi. 29-32.

The parable of the Leaven, Matt. xiii. 33; Luke xiii. 20, 21.

The parable of the Lost Sheep, Matt. xviii. 12-14; Luke xv. $3-7$.

The parable of the Marriage Feast, Matt. xxii. 1-10; Luke xiv. 15-24.

The woe pronounced on the Pharisees, Matt. xxiii. 13-36; Luke xi. $37-80$.

The woe pronomneed on Jerusalem, Matt. xxiii. 37-39; Luke xiii. 34,35 .

The faithful and unfaithful stewards, Matt. xxiv. 45-51; Luke xii. $42-48$.

The parable of the Talents and of the Pounds, Matt. xxv. 14-30; Luke xi. 11-28. ${ }^{1}$

The instances of identity of language in these two Gospels are very numerous and striking; sometimes the identity is absolute, as in the two following examples:-

\section{Matт. vi. 24.}

No man can serve two masters: for either he will hate the one, and love the other; or else he will hold to one, and despise the other. Ye cannot serve God and mammon.

MATT. xi. 25-27.

I thank thee, O Father, Lord of heaven and earth, that Thou didst
LukE xvi. 13.

No servant can serve two masters: for either he will hate the one, and love the other; or else he will hold to one, and despise the other. Ye eannot serve God and mammon.

\section{Luke x. 21, 2 2.}

I thank thee, O Father, Lord of heaven and earth, that Thon didst

1 These parables, notwithstanding their resemblances, are generally considered as different. See Trench on the Parables. 
hide these things from the wise and moderstanding, and didst reveal them nnto babes: yea, Father, for so it was well-pleasing in Thy sight. All things lave been delivered unto me of my Father: and no one knoweth the Son, save the Father; neither doth any know the Father, save the Son, and he to whomsoever the Son willeth to reveal him. hide these things from the wise and understanding, and didst reveal them unto babes: yeil, Father, for so it was well-pleasing in Thy sight. All things have leen delivered ruto me of my Father: and no one knoweth who the Son is, save the Father; and who the Father is, save the Son, and he to whomsoever the son willeth to reveal him.

Numerous other passages might be given where the identity of language is also striking; for example, compare Matt. iii. 7-10, 12 with Luke iii. 7-9, 13; Matt. vii. 7-11 with Luke xi. 9-13; Matt. vi. 25-33 with Luke xii. 22-31; Matt. xiii. 33 with Luke xiii. 20, 21; Matt. xxiv. 43-51 with Luke xii. 39-46. Now this greatly complicates the problem. If the fact were that only the three Gospels agreed, or if only Matthew and Mark, and Mark and Luke agreed, we might refer them to a common source or an original Gospel, either the Gospel of Mark or one closely resembling it. But when Matthew and Luke also agree in ineidents and discourses not found in Mark's Gospel, and where there is an identity of language in their statements, we are constrained to conchule, either that Matthew eopied from Luke, or eonversely, - an hypothesis which we shall afterwards see camnot be maintained,-or that there was a common souree, whether oral or written, which contains the sayings found in hoth.

3. The single narrative-Clint busides the coincidences common to these Cospels, each Gospel has its own peculiar incidents and diseourses; there is a single as well as a twofold and threefold narrative.

The following incidents and discourses are peenliar to the Gospel of Matthew: the renealogy of Jesus from David (i. 1-17); the anmunciation to Joseph (i. 18-25); the atoration of the Margi, the massacre of the infants in liethlehen, and the flight into ligy tit (ii. 1-2:3): the Sermon on the Mount, given as a whole (v., vi., vii.); the eure of two hind men (ix. 27-94); the invitation to the weilly and heavy laden (xi. 28-30); the parahles of the Tares, the Hidrlen Treasure, the Merehant secking goolly Fearls, and the Inagr Net 
(xiii. 24-53); the attempt of Peter to walk on the sea (xiv. 28-33); the blessing pronouneed on Peter (xvi. 17-19); the parables of the Unforgiving Servant (xviii. 21-35), the Householder hiring Labourers for his Vineyard (xx. 1-16), the Ten Virgins (xxv. 1-13), and the Sheep and the Goats (xxv. 31-46); the resurrection of the saints after Christ's death (xxvii. 52, 53); the bribery of the soldiers to say that the disciples stole the body (xxviii. 11-15); the appearance of Christ on a mountain in Galilee, and the institution of Christian baptism (xxviii. 16-20).

The Gospel of Mark has little that is peculiar. Nearly the whole of it is contained in the Gospels of Matthew and Luke; about two-thirds of it are common to these Gospels, whilst the other third is contained partly in the Gospel of Matthew and partly in the Gospel of Luke,-a mere fragment, in all about seventeen verses, is peculiar to Mark. These peculiarities are the parable of the inperceptible Growth of the Seed (iv. 26-29), the cure of a deaf man who had an impediment in his speech (vii. $32-37$ ), the cure of a blind man at Bethsaida (viii. 22-26), and the account of the man who followed Christ from Gethsemane, having a linen cloth cast about him (xiv 51,52). It may be thought that Mark's Gospel is a compilation, and that the incidents are borrowed from the Gospels of Matthew and Luke. But we are prevented from adopting this solution; a careful examination of Mark's Gospel proves that he is more graphic in his descriptions than the other two evangelists; that his account is more like that of an eye-witness than of a compiler, and that the incidents recorded are more expanded than those found in the other Gospels. Mark's Gospel is shorter, because it relates chiefly the incidents of the life of Christ, and gives only a few of His discourses.

The Gospel of Luke contains the following incidents and discourses peculiar to it:-The vision of Zacharias (i. 5-25); the annunciation (i. 26-38); the meeting between Elizabeth and Mary (i. 39-45); the song of Mary (i. 46-56); the birth of the Baptist and the prophecy of Zacharias (i. 57-80); the journey of Mary and Joseph to Bethlehem (ii. 1-7); the angel's message to the shepherds (ii. 8-20); the song of 
Simeon (ii. 25-35): Anna the prophetess (ii. 36-40); Christ and the doctors (ii. 41-52); the genealogy of Jesus from Adam (iii. 2:-38); the rejection of Jesus by the inhabitants of Nazareth (iv. 14-30); the miraculous draught of fishes (v. 1-11): various sayings of Jesus seattered thronghout the Gospel, and which are contained in Matthew's Sermon on the Mount; the raising of the widow's son at Nain (vii. 11-17); the anointing of the woman who was a simer, and the parable of the Two Debtors (vii. 36-50); the wish expressed by James and John to eall down fire on the Simaritans (ix. 51-56); the parable of the Good Samaritan (x. 25-37): our Lord's reception by Mary and Martha (x. 38-42); the parable of the Rich Man who boasted of his Goods (xii. 13-21); the parable of the Barren Fig Tree (xiii. 6-9): the cure of the woman with the spirit of infirmity (xiii. 10-17); the eure of the dropsical man on the Sabbath (xiv. 1-6); the parables of the Marriage Feast (xiv. 7-24), the Lost Piece of Money (xv. 8-10), the Prodigal Son (xv. 11-32), the Unjust Steward (xvi. 1-13), and the Rich Man and Lazarus (xvi. 19-21); the ten lepers and the grateful Samaritan (xvii. 11-19); the parable of the Unjust Judge and the Importunate Widow (xviii. 1-8); the parable of the Pharisee and the Publiean (xviii. 9-14); the visit to Zacehreus (xix. 1-10); our Lord's examination before Herod (xxiii. 8-12); the address to the daughters of Jerusalem (xxiii. 27-31); the disciples going to Emmaus (xxiv. 13-35), and the ascension (xxiv. 50,51).

There is a considerable passage in the midulle of the Gospel of Luke, ineluding at least three chippters (xiv., xr., xvi.), ${ }^{1}$ which has only a very few resemblances to the other two Gospels. There are in it a few sayings and incidents which are eommon to all the synopties, and a few which are eommon to Matthew and Luke, but by far the larger portion is peculiar to Luke. It eontains the important parables of the Marriage Feast, the Lost Piece of Money, the lost sheep,", the l'rodigal son, the Unjust Steward, and the lich Man and Latzarus. It has received various names, boing called "the

1 Most arities consider the great insertion as including lake ix. 51 xitii. 41.

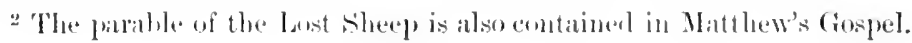


Journal of Travel" (Reisebericht), "the great interpolation or insertion " (die grosse Einschaltung), and "the Perean seetion." It would appear that Luke here made use of a source of information which was not possessed by the other two evangelists.

The amomt of agreement between the three evangelists has been given in various forms by different writers. Thus, Archbishop Thomson says: "If the history be harmonised and then divided into 89 sections, it will be found that in 42 of these (nearly a half) all the narratives eoineide, that 12 more are given by Matthew and Mark only, that 5 are eommon to Mark and Luke only, and that 14 are found in Matthew and Luke. To these should be added 5 peculiar to Matthew, 2 to Mark, and 9 to Luke, and the number is eomplete." 1 Bishop Westeott observes: "If the total eontents of the several Gospels be represented by 100 , the following table is obtained:-

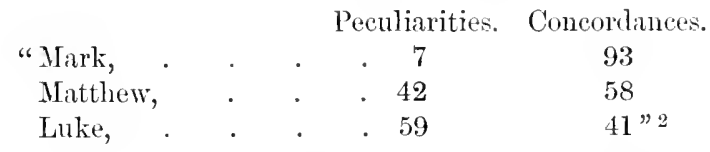

Another peenliarity, proving the mutual dependenee of the three Synoptists, is the eoineidenee between them in their quotations from the Old Testament. In general, the quotations are made from the Septuagint; and in these eases the verbal agreement between them is easily aceounted for, as these quotations are from the same version. But there are a few quotations from the Old Testament, in which the evangelists verbally agree, which are taken neither from the Hebrew nor from the Septuagint, and which aeeordingly seem to indieate that they were found in the doemment or doenments which were common to them. Thus, for example, the quotation from Isa. xl. 3 is thus given in the three Synopties:

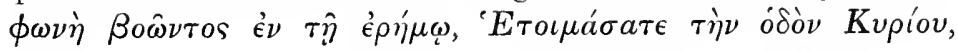

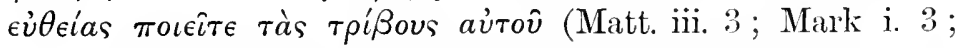

I The Specker's Bible: New Testament, vol. i., Introduction, p. viii. See also article on the Gospels in Smith's Dictionary of the Bible.

2 Westcott's Introduction to the Study of the Gospels, p. 177. Reuss gives a list of agreement according to the number of verses (History of the N.T. p. 177, translation), and Schaff according to the number of words. Bishop Westcott's table is taken from Stroud's Greek Harmony of the Gospels, Introduction, p. cxvii. 
Luke iii. 4); whereas in the Septuagint, instead of $\tau \rho$ ißovs $\boldsymbol{a} \dot{v} \tau o \hat{v}$, we have the very important variation $\tau \rho i \beta o v s ~ \tau o \hat{v}$ $\theta \epsilon o \hat{v} i \mu \hat{\omega} \nu{ }^{1}$ So, also, the quotation from Zech. xiii. 7 , in which Matthew and Mark agree, except that Matthew adds

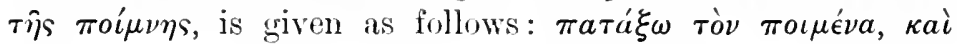

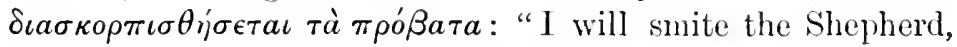
and the sheep shall be scattered abroad" (Matt. xxvi. 31; Mark xiv. 37); whereas the words in the Septuagint are:

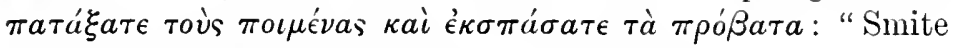
ye the shepherds, and draw ont the sheep." "2

It is also important to remark that the identity of language is found ehiefly in the sayings of others, and especially in the sayings of Jesus, and not in the mere narrative or statement of facts. ${ }^{3}$ The words of our Lord are frequently found verbatim in the different Gospels, especially in the sayings of our Lord contained in the Sermon on the Mount in Matthew's Gospel, and the precisely similar sayings found in different parts of Luke's Gospel. "By far the larger portion of this verbal agreement," observes Norton, "is found in the recital of the words of others, and particularly of the words of Jesus. Thus, in Matthew's Gospel, the passages verbally coincident with one or both of the other two Gospels amount to less than a sixth part of its contents; and of this, about seven-eighths oceur in the recital of the words of others, and only about one-eighth in what, by way of distinction, I may call mere narrative, in which the evangelist, speaking in his own person, was unrestrained in the ehoice of his expressions. In Mark the proportion of coincident passages to the contents of the Gospel is about one-sixth, of which not one-fifth occurs in the narrative. Luke has still less agreement of expression with the other evangelists. The passages in which it is found amount only to about a tenth part of his Gospel; and

1 In the Hebrew: "Make straight in the desert a highway for our (iorl."

2 There is here, lowever, a differenee of reating in the mannseripts of the septuagint. In the Helnew it is: "Smite the shepherd, and the sheep shall be seattered."

"See Bishop Thirlwall's introduction to his transhation of Schleiermather's st. Lotke, p. 36 . 
but an inconsiderable portion of it appears in the narrative, in which there are very few instances of its existence for more than half a dozen words together." 1

Another peculiarity in the Synoptic Gospels, on which stress has recently been laid, is the supposed existence of what have been called "doublets"; that is, expressions or incidents which are repeated in the same Gospel. Attention has been drawn to this point by Mr. Badham in his ingenious work on the Formation of the Gospels. He gives a long list of donblets, extending over twenty pages, found in the three Synoptic Gospels. ${ }^{2}$ Most of these doublets, however, when examined, depend only on shight resemblances, or the repetition of a few words, and many of them are strained; and when the number is reduced by the omission of these, only a small residue remains. The following are a few of the most obvious and striking: In the Gospel of Matthew it is twice stated, in almost the same words, that Jesus went through the cities and villages of Galilee, preaching the gospel of the kingdom, and healing all mamer of disease and all manner of sickness (Matt. iv. 23, ix. 35). ${ }^{3}$ The cure of a dumb man possessed with a devil, with the remark of the Pharisees upon it, that $\mathrm{He}$ cast ont devils by Beelzebub, is twice recorded (Matt. ix. 32-34, xii. 22-24). So also in the Gospel of Luke, the saying about lighting a candle and putting it under a couch (Luke viii. 16, xi. 33), and the warning, "Whosoever shall save his life shall lose it; and whosoever shall lose his life for my sake, the same shall save it" (Luke ix. 24, xvii. 33), are twice repeated in language almost identical. It is twice stated that there was a contention among the disciples which of them should be the greatest (Luke ix. 46, xxii. 24). The inference which Mr. Badham draws from these phenomena is, that these donblets occurred in separate documents used by

${ }^{1}$ Norton on The Genuineness of the Gospels, vol. i. 1. 240.

${ }^{2}$ Badham's Formation of the Gospels, pl. 12-23. This is a very ingenious, but somewhat unsatisfactory book. The recognition of doublets in the Gospel is interesting and suggestive, but we do not think very important.

3 These words refer to two different cireuits of Christ in Galilee; the one at the commencement of His Galilean ministry, and the other towards its close. 
the evangelists. But other reasons may be assigned for them. There is no improbability in the supposition that our Lord might repeat sayings of primary importance, especially if they were of the nature of proverbial expressions, such as that of coneealing the light, and that solemn warning about saving the soul; the contention among the clisciples for preeminence might have occurred on two different oecasions; and the two incidents recorded in Matthew's Gospel of the eure of the dumb man possessed with a devil differ in some respeets, and both might have occurrel. ${ }^{1}$ Thus there are two miracles of feeding the multitude which differ in several particulars, and only one of them is recorded by Luke.

II. Points of differenee.-In considering the Synoptic problem we must attend, not merely to the points on which the evangelists agree, but also to the points on which they differ; the one class of phenomena is of as much importance as the other. We have already seen that whilst there is upon the whole an agreement between the Gospel of Mark and the other two, the Gospels of Matthew and Luke differ materially in their contents. Each has incidents and discourses which the other wants. Even in those passages where there is a general agreement, there are often important verbal differences. Thus in the encouragement to prayer given by our Lord, Matthew has: "How much more shall your Father which is in heaven give good things (áratá) to them that ask Him?" (Matt. vii. 11); whilst Luke instead of "good things" has "the Holy Spirit" ( $\pi \nu \epsilon \hat{v} \mu a$ ä $\gamma \iota 0 \nu$ ) (Luke xi. 13). In repelling the assertions of the P'harisees that $\mathrm{He}$ east ont devils through Jeelzebub, Jesus is reported by Matthew as saying: "If I by the Spirit of Cod (ćn $\pi v \in \dot{v} \mu a \tau \iota$ $\theta \epsilon o v)$ cast out clevils" (Matt. xii. 28): whilst Luke has "by

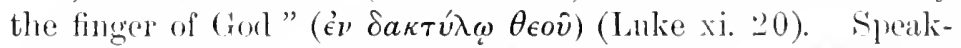
ing of the power of faith, our Lord, aceording to Matthew, says: "If ye have faith as a grain of mustard seed, ye shall saly to this mountain ( $\tau \hat{c}$ ó yonder place" (Matt. xvii. 20); "whilst luke has: "Whoso-

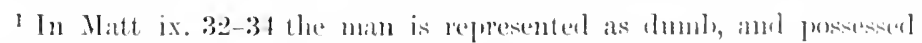

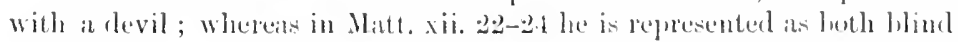
antl duml. 


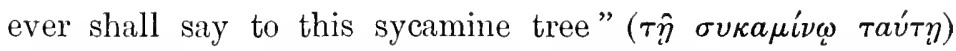
(Luke xvii. 6). These differences cannot be accounted for on the ground that they are different translations from the Aramaic. ${ }^{1}$

There are also striking differences in many of the events of our Lord's life which are recorded by Matthew and Luke. Thus in the accounts given of the birth of Christ-an event omitted in Mark's Gospel--there are important variations. There is no discrepancy between their accounts; both assert that Christ was born in Bethlehem, but they evidently drew their information from different sources. In Matthew the annunciation is made to Joseph; in Luke it is made to Mary. Matthew mentions the visit of the wise men; Luke, the visit of the shepherds. Matthew relates the massacre of the infants in Bethlehem and the Hlight to Egypt, neither of which particulars is recorded by Luke; whilst Luke mentions the circumeision and the presentation in the temple, both of which are omitted by Matthew. There is also a remarkable difference between Matthew and Luke with regard to the so-called Sermon on the Mount. In Matthew's Gospel it is given as one connected disconrse; whereas the sayings contained in that discourse are scattered throughout Luke's Gospel, and are to be found in at least ten different places; almost the whole sermon given in Matthew's Gospel is thus contained in the Gospel of Luke. Comparing it as found in a connected form in Matthew's Gospel with the scattered portions of it in Luke's Gospel, we have the following table of coincidences :-

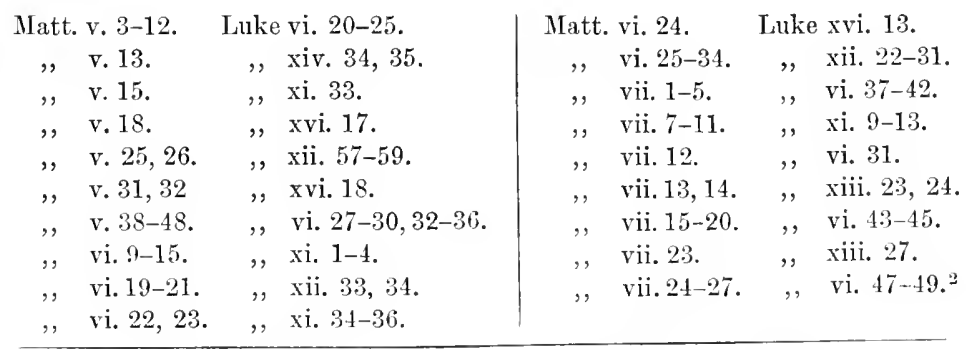

1 See on these verbal variations, Brnce's Kingdom of God, p. 17.

2 See Rushbrooke's Synopticon, 1'1. 138-147; Holtzmann's Einleitung, 1). 356,357 . 
But not only are the sentiments the same, but there is often a remarkable identity in the language in which these sentiments are expressed. Compare Matt. v. 25, 26 with Luke xii. 57-59; Matt. vi. 9-13 with Luke xi. 1-4; Matt. vi. 21 with Luke xii. 34 ; Matt. vi. 24 with Luke xvi. 13; Matt. vi. 25-34 with Luke xii. 22-31; Matt. vii. $3-5$ with Luke vi. 41, 42; Matt. vii. 7-11 witl Luke xi. 9-13. ${ }^{1}$ On the other hand, there are remarkable differenees, as, for example, in the Beatitudes $;^{2}$ in Matthew they are extended, whilst in Luke they are abbreviated, and a series of corresponding denunciations is attached to them. Different inferences have been drawn from these points of agreement and difference. ${ }^{3}$ Some suppose, but contrary to all prohability, that our Lord delivered two similar diseourses, the one on the mount, recorded by Matthew, and the other on the plain, reeorded by Luke. ${ }^{4}$ Tholuck gives the preference to the form contained in Matthew's Gospel, arguing from the continuity of its thoughts, and thinks that the narrative of Luke has less elaim to originality. ${ }^{5}$ Others, as Olshansen and Godet, suppose that Matthew collected the sayings of our Lord into one discourse; whereas Luke gives them at the time when they were spoken, ${ }^{6}$ or, aceording to others, inserts them as he

1 See Paul Ewald's Evangelienfruge, 1. 216.

2 In Hathew there are eight beatitudes; in Luke there ane four.

${ }^{3}$ In Matthew's Gospel it is sairl that our Lord went up to a mountain and there addressed the multitule; and from the mamer in which the discourse is introduced, we are led to suppose that it was then delivered. Probally a large portion of it was delivered on that occision; and additions were afterwards added hy the evangelist.

4 There can he no reasonable doubt that the discourse related in Luke vi. $20-49$ is the same as that related by Matthew.

5 Tholuck's Sermon on the Mount, translation: "The narrative of

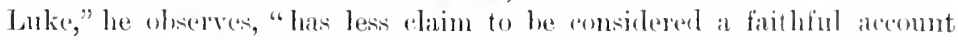
than that of Mathlew" (p. 17). "Our conclusion is that the artangement of the sayings of onr hord given ly Matthew in lis alcenut of the sernom on the Momt is in the matin correct." (1). 27).

6 Olshatusen, On the ciospels, vol. i. p. 182: "Th" unity of the Sirmon

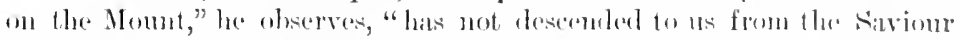
Ilimself, hut from Matthew." "It chees not apporar to me," wherpes (a)det, "that in the majority of these "akes (those given ly luke) a thorough sturlent of the subject could refuse to give the proference to the position indicated by the third Gospet." Godet's biblicul Studies, 117. 15, 16. 
found them in the written documents which he employed, or in the oral sourees from which he drew his materials. ${ }^{1}$

Several remarkable points of variation oecur in the aceounts of the passion given by Matthew and Luke. Matthew relates the suicide of Judas, the dream of Pilate's wife, and informs us that at the death of Christ the vail of the temple was rent in twain, the earth did quake, the graves were opened, and many bodies of the saints which slept arose. Lnke relates the examination of our Lord before Herod, the eonversion of the penitent thief on the eross, and gives us that divine prayer for forgiveness: "Father, forgive them : for they know not what they do." 2

Matthew and Luke also vary in their aecounts of the resurreetion of our Lord. Matthew relates the rolling away of the stone by an angel, the address of the angel to the women, the appearance of Jesus to them, the terror of the guard, the bribery of the soldiers to induee them to diffuse a false aecount of the resurrection, the appearanee of Christ to the disciples in Galilee, and the great commission to make diseiples of all nations. Luke relates the address of the angels to the women at the sepulehre, the appearance of Christ to the two diseiples going to Emmaus and to the disciples in Jerusalem, and eoncludes with a referenee to the aseension. In his Gospel the appearances of Christ after His resurrection are confined to Jerusalem and its neighbonrhood; there is no mention of Galilee; and were it not for the accounts eontained in the other Gospels, it might be inferred that all the appearances occurred on one day.

There is also a considerable diflerence in the chronologieal order in which the events are recorded. ${ }^{3}$ There is a general agreement, but a difference in detail. Thus our Lord's lamentation over Jerusilem was, aecording to Luke's Gospel, pronounced during the eourse of His ministry in

${ }^{1}$ It must be acknowledged that the connection discernible in the different parts of Matthew's account is in favour of the unity of the discourse as given by him. We must leave this point undetermined.

2 For the different Synoptic histories of the passion, see Westcott, Introduction to the Study of the Gospels, 1P. 299-304.

${ }^{3}$ Credner's Einleitung, p. 169. 
Galilee (Luke xiii. 34); whilst Matthew's Gospel gives it in nearly identical words as uttered at Jerusalem before $\mathrm{He}$ suffered (Matt. xxiii. 37). ${ }^{1}$ The eure of the blind man at Jericho is staterl by Luke as having oecurred when our Lord entered Jericho (Luke xviii. 35), and by Matthew and Mark when He was leaving it (Matt. xx. 29; Mark x. 46). ${ }^{2}$ The cure of the leper is represented by Matthew as having taken place before $\mathrm{He}$ entered into Capernamm (Matt. viii. 1, 5), whilst by Mark and Luke it is represented as having been performed after He had left that eity (Mark i. 39, 40 ; Luke iv. 44 , v. 12). It is evident that the evangelists did not confine themselves to any preeise chronologieal order; their olject was to give incidents in the life of Christ, but withont any reference to the precise time of their ocenrence. ${ }^{3}$

Such, then, are the conditions of the problem. There is an agreement not merely in the incidents recorded, as if a seleetion had been made of the numerous aetions and discourses of Jesus, but frequently also in the very language employed; whilst, on the other hand, there are remarkable points of difierence. The solution of the problem must meet all the facts of the case - the points of agreement as well as the points of difference; the key must be suited to the loek-the discovery of that key is the great question of present New Testament criticism.

\section{Soulices of the Symoptic Gospels.}

We now eome to the most perplexing and diffienlt division of om subject-the somrees of the synoptic Gospels.

1 There is no improbahility in supposing that the denunciation was bice uttered by our lard.

2 This aplarent discregancy in the synoptic (iospels is afterwards fully dismisuded.

3. See Westeott's Introrduction to the Study of the Gospels, chitpter vii.

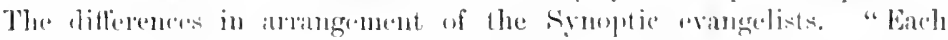

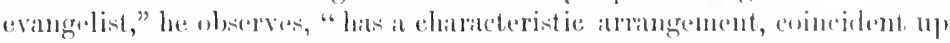

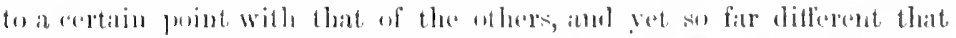

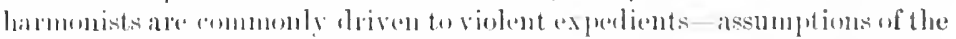

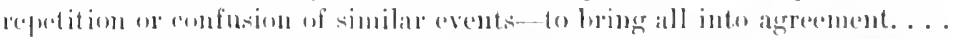
It is from the first unlikely that writings which do mot aim at comploteness

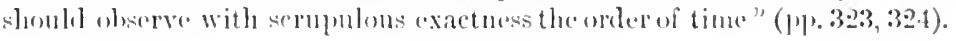


Indeed, it is the most difficult problem in the criticism of the New Testament. The recent literature upon it, both in Germany and in our country, in special works, monographs, and periodicals, is not only extensive, ${ }^{1}$ but confusing. Each author advances a theory of his own; and one is perplexed with their number and variety, and with the plansibility of antagonistic theories. The task of weighing the different arguments is great; and the problem is so complicated and involved that one almost despairs of a solution which would meet all the points of the case. Still some approach to a solution has been made. There are points which are now regarded by most writers on the subject as settled: although there are others still under discussion, and perhaps a full explanation is not yet attainable. Four hypotheses have been advanced to account for the points of agreement in the Synoptic Gospels: the hypothesis of mutual dependence; the hypothesis of oral tradition; the hypothesis of an original document or documents; and a variety of this last hypothesis, the so-called two document-hypothesis. Each of them is complicated by different forms of presentation; thus the theory of mutual dependence admits of no less than six variations, each of which has been supported; the hypothesis of oral tradition is complicated by the different languages in which the tradition may have been transmitted, whether Greek or Aramaic; the hypothesis of an originai document or documents admits of an almost endless number of variations; and the two document-hypothesis is complicated by the different views of the nature and extent of these documents. These hypotheses are not mutually exclusive; the adoption of one does not necessarily assume the rejection of the other three. There may be an element of truth in each; indeed, the true settlement of the question may be the result of a

${ }^{1}$ Of recent books may be mentioned Abbott and Rushlbrooke's Common Trudition of the Synoptic Gospels, 1884; Carpenter, The First Three Gospels, 1890 ; Badham, The Formution of the G'ospels, 1892; Jolly, The Synoptic Problem for English lieaders, 1893; Barnes, Cunonical and Uncanonical Gospels, 1893 ; Wright, Composition of the Four Gospels, 1890. Besides the able articles by Dr. Sanday and Professor Marshall in the Expositor for 1891, and Dr. Sanday's article on the Gospels in the new edition of Smith's Dictionary of the Bible, 1893. 
combination of all four. The Gospels may be mutually dependent: much of their contents may have their origin in oral tradition: some common document or documents may have been used: and there may have been one fundamental original Gospel and a collection of the sayings of our Lord which may have been the primary sources of the Synoptics. The examination of the subject requires the greatest eaution, and complete freedom from preconceived opinions.

\section{A.-TIE THEORY OF MUTUAL DEPENDENCE.}

The most natural solution of the problem is to suppose that the evangelists eopied from each other. The similarities between them may be accounted for on the supposition that one Gospel was a compilation from the other two, and that one of the two borrowed from the other; for example, it may be supposed that Mark is an abbreviation of Matthew and Luke, and that Luke is indebted to Matthew. Thus Augustine, assuming the priority of Matthew, asserts that Mark was dependent on him. "Mark," he observes, "follows Matthew as if he were his attendant and abhreviator. ${ }^{1}$ In his narrative he has nothing in concert with John, he has very little peculiar to himself, he has still less in concert with Luke alone: but in concert with Matthew he has a very large number of passages. He relates much in words almost identical with those used by Matthew, or by him in connection with the other Gospels." ${ }^{2}$ This theory has in recent times been brought into prominence by Griesbach, ${ }^{3}$ and was formerly acepted as the true solution by many eminent crities. It was adopted and ably supported by 13leek. ${ }^{4}$ It has now, however, been generally abandoned, as insufficient by itself alone to accomt for all the diffieulties of the problem.

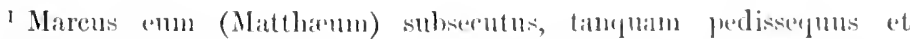
bieviator ejus videtur.

2 Augustine, Consensus reongelisterum, i. 2.

"Historisch-Kritischer Versuch ibur die Entstehumg der schriftichen Evangelien. The hypothesis has received the name of Gieshach's theory".

'Bleck's introduction to the N.T. vol. i. 1. 259 It'. tramslation. 
The three Gospels admit of six possible arrangements, each of which has been supported by different critics. 1 . There is the order in the canon, Matthew, Mark, Luke. Matthew wrote first, Mark made use of his Gospel, and Luke was indebted to both. ${ }^{1}$ This order was adopted, although on different grounds, by Bengel, Credner, Grotius, Hug, Hilgenfeld, and Hengstenberg. 2. Matthew, Luke, Mark. Mark's Gospel has been supposed to be a compilation drawn from the Gospels of Matthew and Luke, whilst Luke is supposed to have drawn from Matthew. This was the theory advanced by Griesbach, and adopted by De Wette ${ }^{2}$ and Bleek. 3. Mark, Matthew, Luke. Mark has been regarded as the original Gospel, whilst Matthew is supposed to have made use of Mark, and Luke both of Mark and Matthew. The theory adopted by Ritschl, Reuss, ${ }^{3}$ Meyer, Smith of Jordanhill; and with various modifications by Ewald, Holtzmann, Weiss, and Weizsäckèr. 4. Mark, Luke, Matthew. Mark has been supposed to be the original Gospel, Luke copied from him, and Matthew from both Gospels. The theory adopted by Hitzig and Volkmar. ${ }^{4} 5$. Luke, Matthew, Mark. Luke has been held to be the original Gospel followed by Matthew, whilst Mark is supposed to have copied from both. This arrangement has been adopted by Evanson ${ }^{5}$ and Stroud. ${ }^{6} \quad$ 6. Lnke, Mark, Matthew. Luke has been supposed to be the original Gospel followed by Mark, whilst Matthew copied from both. The theory adopted by Vögel and Schneckenburger.

The directly opposite theory has been maintained by other critics: that the three Gospels are all independent of each other: that the Gospel of Mark, although most of its contents are contained in the Gospels of Matthew and Luke, was never seen by these writers, but that the agreement is

1 The order of the Gospels generally found in manuseripts and versions, and which would seem to presuppose the order in which they were written, gives plausibility to this theory.

${ }^{2}$ De Wette's Einleituny in des N.T. \$ 82.

${ }^{3}$ Reuss, History of the N.T., translated by Houghton.

4 Volkmar's Markus.

5 Evanson's Dissonance of the Four generally reeeived Gospels.

6 Stroud, Greek Harmony of the Gospels, Introduction, 1'. lix. 
to be aceounter for from other causes, as the preaching of the apostles, forms of eatechetical instruetion, or oral tradition. This opinion is supported, thomgh for clifferent reasons, by Alforl, Ebrarl," Schall, Aluott," and liow:" Thus Alford observes: "There is no reason frum their internal structures to believe, Int every reason to disbelieve, that any one of the three evangelists hat aceess to either of the other two Gospels in its present form." + And Schatt' remarks: "There is no direct evidenee that any of the three Synoptists saw and used the work of the others; nor is the agreement of such a character that it maly not be as casily and better explained from antecedent sources." 5

But it is difficult to see how the resemblances in the Gospels, extending not only to incidents and discourses, but even to verbal expressions, can be accomnted for on the supposition of mutual independence. If three writers had such a close resemblance in their writings as the evangelists have, we would naturally conclude that they depended upon each other. At least it is evilent that there must be some common grom dwork. If the evangelists did not see each others' writings, there must have been either an oral Gospel which had become stereotyped, or some common document or documents used by all of them.

The Crospel of Mark camnot be considered as a compilation from Matthew and Luke. That it is a eompilation has been often asserted by those who hold the theory of mutual dependence. It was first brought forward by Angustine, and is the hypothesis advaneed by Griesbach. Alnost all the contents of Mark's Gospel, with a few exceptions, are to be found either in the Gospel of Matthew or in that of Luke. This theory has been ably supported by bleek. He adduces several passiges where it woukd appear that Mark combined the statement of Ifayl and Luke. Thus in the narrative of

1 Elrarl, The Gospel History, \$120, translation, 1. 554 If.

2 Abhutt and linshbrooke's common Trutition of the Synoptic Gospels, 1. vi.

${ }^{3}$ Row, The desus of the Exangelists, 1. 2.2.2.

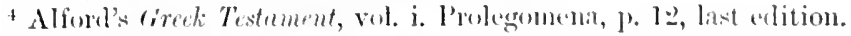

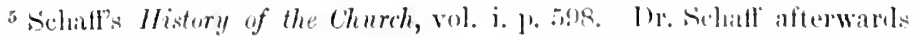
chinged his opinion; see farther on. 
the miracles of Christ, Matthew states that they were performed "when even was come" (Matt. viii. 16); and Luke: "when the sun was setting" (Luke iv. 40): Mark combines the two: "at even when the sun dir set" (Mark i. 32). So also in the cleansing of the leper, Matthew says: "Straightway his leprosy was cleansed" (Matt. viii. : ): Luke: "Straightway the leprosy departed from him" (Luke v. 13); Mark combines the two: "Straightway the leprosy departed from him, and he was made clean" (Mark i. 42). In the account of the Lord's entrance into Jerusalem, Matthew writes: "And when they drew nigh unto Jerusalem, and came unto Bethphage, unto the Mount of Olives" (Matt. xxi. 1); Luke: "When He drew nigh mo Bethphage and Bethany, at the mount that is called the Mount of Olives" (Luke xix. 29); Mark combines the two: "And when they drew nigh unto Jerusalem, unto Bethphage and Bethany, at the Mount of Olives" (Mark xi. 1). From those and similar examples Bileek draws the inference: "This is best explained by supposing that Mark had both Matthew and Luke before him, and used them both." 1

On the other hand, Mark has not the characteristics of a compiler or epitomiser. Although his Gospel is much shorter than the other two, and may at first glance be considered as an abbreviation, yet when it is attentively studied it is found that this cannot be the case. What Mark does narrate is recorded at greater length than by the other evangelists, and he adds a variety of particulars and little touches which are wanting in the other Gospels; so that in many of the incidents recorded by him, instead of epitomising, he enlarges. There is a peculiar freshness and originality in his descriptions. However we may account for it, Mark has more of the characteristics of an eye-witness than the other two. $\mathrm{He}$ descends to particulars, and describes the events as if he had actually seen them. Thus, to take a few examples: in describing the case of the demoniac boy, whom our Lord cured after His descent from the Mount of Transfiguration, Mark tells us of the scribes disputing with the disciples, of

I Bleek's Introduction to the N.T. vol. i. 1'p. 260-262. For a similar opinion, see Davidson, Introduction to the N.T. 4th ed. vol. i. pp. $481 \mathrm{ff}$. 
the amazement of the people when they saw the Lord, of the conversation between the father of the boy and Christ, and of the paroxysm that seized the lad (Mark ix. 14-29). It is Mark who tells us that the amiability of the rich ruler, who came to our Lord asking what he must do to inherit eternal life, excited the love of Christ: "Jesus, beholding him, loved him" (Mark x, 21). It is Mark who tells us that when our Lord cured the deaf and dumb man, He took him aside from the multitude, put His fingers into his ears, and spit and touched his tongue; and looked up to heaven, and sighed, saying, Ephphatha (Mark vii. 33, 34). It is Mark who tells us that when the Pharisees manifested their unbelief and hostility, demanding a sign from heaven, Jesus sighed deeply in spirit, filled with indignation on account of the hardness of men's hearts (Mark viii. 12). Mark relates the incident of the young man rising from his bed and in his night clothes following Jesus, and those who apprehended him (Mark xiv. 51); and he informs us that Simon the Cyrenian, who carried the cross of Christ, was the father of Alexander and Rufus (Mark xv. 21). We have here the account of an eye-witness, recording minute particulars, imparting vivid touches to the narrative. ${ }^{1}$ The omissions of Mark also prove that he could not have had the other Gospels before him. There are events recorded in the Gospels of Matthew and Luke which an abbreviator would not have omitted; for example, the account of the supernatural birth of Christ.

But whilst we maintain the originality of Mark, it is a much more difficult question to determine the relation of his Gospel to those of Matthew and Luke. That the relation is intimate, is undoubted; but does it extend so far as to imply that these two evangelists used the Gospel of Mark as one of their authorities? The negative has been strongly maintained by many eminent eritios, ${ }^{2}$ and the agreenent between the Gospels has been referred entirely to oral tralition.

1 Many other instances might be given; rompare the healing of the jamalytic, Mark ii. 3-12, with Matt. iv. 2-8; also the aceomuts of the murder of John the baptist, and of Peter's denial. See Salmon's Introduction to the N.T. 1). 185-187.

"Alford, Westeott, Selafl, Plumptre. 
But the resemblances are too minute, exact, striking, and numerous to be attributed to this source alone. Not only are the incidents the same, but there are long sentences where the words are almost identical. In ordinary literature, if two writings were found to agree in incident and in form of expression with a third, and if that third writing bore all the marks of originality, we would naturally infer that the authors of these two writings borrowed from the third. There is, of course, another alternative, that all three borrowed from a common docmment; but that document, on account of the nature and extent of the similarities, could not have rested on oral tradition, which in its nature is diversified, but must have been written. This is the third hypothesis of solution, that of a written document, which we shall afterwards consider. Besides, the order of the narrative followed in the three Gospels is a presumption in favour of the use of Mark's Gospel by Matthew and Luke. There is often a difference in the chronological order in which the events are recorded by the evangelists; but the order laid down in Mark's Gospel is that which has been generally followed. "There are," observes Professor Sanday, "a few cases where all three Gospels diverge from each other; but, as a rule, if Matthew deserts Mark, Luke agrees with him; and if Luke deserts Mark, Matthew agrees with him. There is no case in which the order of a section common to all three is supported by Matthew and Luke against Mark." ${ }^{1}$

There are, however, various difficulties connected with the assumption that Matthew and Luke saw and made use of the Gospel of Mark. It is difficult to account for Matthew omitting certain portions of Mark's Gospel which are found in Luke, and, conversely, for Luke omitting certain portions of Mark's Gospel which are found in Matthew. A difficulty also arises from the omission, both in Matthew and Luke, of those few passages which are peculiar to Mark. ${ }^{2}$ Yet althongh

1 The Expositor for 1891, vol. iii. fourtl series, p. 189.

2 It has been considered as derogatory to the evangelists to suppose that they used each other's writings; that Luke, for example, should be dependent on Mark. But if he used other documents, as is admitted, why might he not also have used a canonical Gospel ? 
the facts of the ease do not permit us to arrive at a positive eonclusion, the presumption is that both Matthew and Luke saw and used the Gospel of Mark. They did not slavishly and mechanically copy from it; the language, though similar, is not preciscly the same; but they made a free use of it as one of their authorities. In this manner the coincidences of all three Gospels, in incident and expression, so far as we see, ean be explained.

But there are not only eoincidences between all three Gospels, but also between Matthew and Luke in events and discourses not recorded by Mark. In order to aecount for these, can we postulate a mutual dependence between those two Gospels? This has been done by several eminent theologians. Ritsehl, whilst he asserts the priority of the canonical Mark, further maintains the dependence of Luke upon Matthew. ${ }^{1}$ This view has also been maintained, though on different grounds, by Holtzmann, Weiszäcker," Wendt, and Paul Ewald. ${ }^{3}$ It is essential to this theory to suppose that the use which Luke made of Matthew's Gospel was not slavish, but very free and untrammelled. Now, if this opinion is correct, we certainly have a remarkable approach to the solution of the problem. The points of agreement in the Gospels are thus, in a measure, all accomnted for. The coincidences between the three Synoptists arise from the use of Mark as a fundamental Gospel; and the coincidences between Matthew and Luke from the use of the Crospel of Matthew by Tuke.

But there are great, and probably insuperathle, objections to the arloption of this hypothesis. Whilst it may account for the points of correspondence, it loes not account for the points of difference in the Gospels of Matthew and luke. The diversities in the narrative prove that the one (rospel must have been independent of the other. Tuke, for example, the variations in the genealogies of Christ as given ly Matthew and Luke. "If no other proof," observes Jean Alford, "were in existence of the total independence of the present (rospels

1 Gorled's Commentury on Luke's Gospel, vol. i. 1. 41, transtition.

2 Apostolishers Zeitulter, 1. 414.

3 Evengationfruge, 1. 169. 
of Matthew and Luke, their genealogies would furnish what I conceive to be an undeniable one. Is it possible that either of these evangelists conld have set down his genealogy with that of the other before Would no remark have been made on their many, and on such a supposition unaccountable, variations?" The same is the case with the variations in the narratives of the birth, the passion, and resurrection of Christ. If these Gospels were mutually dependent, there would certainly have been a greater agreement. So also in Matthew, in the "Sermon on the Mount," there is a collection of the sayings of Jesus; whilst in Luke the same sayings are scattered throughout his Gospel. If Luke used Matthew's Gospel, we can hardly think that he would have cut up that wonderful discourse into different portions. These facts convince us that the Gospel of Matthew was not one of those documents which Luke employed in the composition of his Gospel. ${ }^{1}$

\section{B. - THE THEORY OF AN OLAL GOSPEL.}

According to this theory, the oral teaching of the apostles and the oral traditions of the actions and disconrses of our Lord are the main sources of the Synoptic Gospels. This theory has been denominated the hypothesis of Gieseler, because that eminent theologian was the first who brought it into prominence. He supposes that without any preconceived plan an oral Gospel gradually resulted from the preaching of the apostles in Jerusalem; and that from this oral Gospel the three Synoptic Gospels were composed about the middle of the first century.2 This view, with different variations, has been adopted by Neudecker, Guericke, Thiersch, Lange, and Ebrard in Germany; by Archbishop Thomson, ${ }^{3}$ Alford,

1 So Meyer, Reuss, Thiersch, and Weiss. The results of our examination of the hylothesis of mutual dependence are: 1. Mark is an original Gospel. 2. In all frolklility, though not certainly, Matthew and Luke make use of the Guspel of Mark as one of their sonrces. 3. Matthew and Luke wrote indepemilently of each other.

2 Gieseler's Hist.-lirit. Versuh iiber die Enstehung und die friihesten Schicksale der schriftlichen Evangelien.

s In his introduction to the Gospels in the Speaker's Commentary, and in the article on the Gospels in Smith's Dictionary of the Bible. 
Westcott, Plumptre, Lumby, and Farrar ${ }^{1}$ in England; by Godet ${ }^{2}$ in Switzerland; and by Norton ${ }^{3}$ and Schaff in America. Thus Bishop Westcott observes: "The primary Gospel was proved in life, before it was fixed in writing. Ont of the countless multitude of Christ's acts, those were gathered in the ministry of twenty years, which were seen to have the fullest representative significance for the exhibition of His divine life. The oral collection thus formed became in every sense coineident with the 'Gospel'; and our Gospels are the permanent compendium of its contents." 4 So also Schaff remarks: "The chief and common sources from which the Synoptists derived their Gospels was undoubtedly the living apostolic traditions or teaching. This teaching was nothing more or less than a faithful report of the words and deeds of Christ Himself by honest and intelligent eyewitnesses." 5

The great office of an apostle was to narrate the history of the life and death of Christ. Thus, on the election of a snccessor to Judas Iscariot, the apostles resolved that, "of the men who have companied with us all the time that the Lord Jesus went in and went out among us, beginning from the baptism of John unto the day when He was received up from us, of these must one become a witness with us of His

${ }^{1}$ Farrar's Messuges of the Books, 1. 26.

2 Godet's Commentary on Luke's Gospel, vol. i. l1'. 33 ff.

${ }^{3}$ Norton, The Genuineness of the Gospels, ]'1. 281-289.

4 Westcott, Introduction to the Cospels, 1. 158, 1st edition.

5 Scluaft's History of the Church, vol. i. 1) 602. Dr. Shehafl alprears lately to have modified his opinions. In a private letter to the anthor, written shortly lefore his death, he says: "I am jnetty certain that there must have beon varions fragnentary Gospels before the amonical Gospels, as is evident forn the prefare to Luke; $I$ ann also convinced that the tratition of Papias concerning an original Helorew Matthew is well fommed, and it would be a great lielp, to critien if this Hebrew Mattlew eond be discovered, which is by 110 means inpossible in view of recent experienee in this age of liscovery. I am also settled in my mind as to the originality and priority of Mark, who has so many pictorial traits, which ean only be explatined in a personal eyo-witness-ship. He wiss the interperer of Peter, and in his rapirl movements lefledts the sanguine impulsive temperanent of his master. I lave no settled opinion als to low far Mathew and Luke have used the Holowe 'lochial' but Matthew and Lnke are certainly inde]endent of each other." 
resurrection" (Acts i. 21, 22). The apostles, in their discourses to the people, and especially in the instructions given to their converts, would dwell upon the actions and teaching of their Master,- the miracles He performed, the parables with which $\mathrm{He}$ taught the multitude, His divine utterances and discourses. By degrees this teaching would become to a considerable extent stereotyped: the same incidents would be dwelt upon, the same discourses repeated, especially the most striking parables and the most weighty sayings, and thus gradually an oral Gospel would be formed.

But with this similarity there would coexist a considerable diversity. There wonld be different centres of tradition in Galilee and in Jerusalem, and these local traditions would necessarily vary. The oral Gospel in Galilee would be different from the oral Gospel in Jerusalem; and thus different collections of traditions might be made. When the Gospel extended beyond the boundaries of Judæa into Samaria, Phœnicia, and the neighbouring provinces, the preachers would carry with them a variety of traditions; one uniform Gospel would not be promulgated. This theory of oral tradition, admitting both of a general miformity and of variations, is supposed to account both for the onnsisterteies and the diversities in the Synoptists. "In the oral narratives of the apostles," observes Norton, "we find the common archetype of the first three Gospels, - an archetype, from its very nature, partly fixed and partly fluctuating, and such, therefore, as is required to account at once for their coincidence and their diversity." 1

The Rev. A. Wright of Queens' College, Cambridge, in a valuable contribution to the literature of the Synoptic Gospels, lays great stress on this theory of an oral Gospel. He supposes that among the early Christians, catechetical schools were established in which the converts to Christianity were instructed in the life of Christ. We are informed that those baptized on the day of Pentecost continued steadfastly in the apostles' teaching (Acts ii. 42). This teaching ( $\delta \iota \delta a \chi \grave{\eta})$ would consist chiefly in imparting oral instruction in the life 1 Nurton, The Genuineness of the Gospels, 1. 289. 
and diseourses of Christ; in short, in matters resembling in substance and form the contents of our canonical Gospels. So also Luke, in dedieating his Gospel to Theophilus, says that he wrote that he might know the ecrtainty of the things

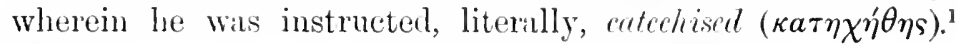
These sehools were established in all plices where the Clnistian religion was planted, in Asia Minor as well as in Palestine. Over these sehools qualified teachers would be appointed, men who were instructed by the apostles or primitive disciples of Christ in the events of His life; some of them, as Mark, belonging to the Petrine sehool, and others, as Luke, belonging to the Pauline sehool. These instruetions were at first given in an oral form, and it was not mitil the removal of the apostles from Jerusalem that the necessity for a written Gospel was felt. Aceording to Mr. Wright, there were six sources from which the Gospels sprung-1. The Petrine tenehing, contained ehiefly in St. Mark's Gospel, and found also in Matthew and Luke, being an oral Gospel. 2. "The utterances of our Lord," mentioned by Papias as the Logia of Matthew, also orally communicated, embedded in Matthew's Gospel, and found also in Luke. 3. The peculiarities of Luke's Gospel, being an oral Gospel, the work of an unknown pupil of Paul, and collected by Luke. 4. Fragments of an oral Gospel outside of these, as the two introduetory ehapters in Matthew, and a few seetions in Luke's Gospel. 5. Written doeuments collected by Luke, as the first two elapters and the genealogy. 6. Editorial notes written by the writers of these Gospels. ${ }^{2}$

This theory of oral tradition has much to commend it. The ultimate somrees of the Gospels, before anything was eommitted to writing, must have been the oral teaching of the apostles and primitive disciples. There nust have been an oral before there was a written Gospel. The oral element is an important factor in the formation of our Gospels which must not be overlooked. It must enter largely into any

1 Mr. Wright puts special weight on Gal. vi. 6, where the verh yorroses is emplored.

2 Wright's Composition of the Four Gospels, London, 1893; also article in the Thinker for Feluruary 1895. 
theory which professes to be a solution of the Synoptic problem. ${ }^{1}$

But this theory by itself is inadequate to account for all the coincidences and diversities of the narrative. There are at least three objections to it. 1. It cannot accomnt for the similarity or agreement which pervades the Gospels. If the Gospels arose from oral tradition, we should not have expected so great an identity of particulars in a life so full as that of Christ. Nor is this agreement confined to events, but extends to expressions and words. Tradition does not express itself in the same terms; even in the description of the same event by eye-witnesses, there is always a variety in the expressions employed. It has indeed been said that there might be set phrases and current expressions; but not to speak of the mechanical formation of the Gospels which such a view involves, and which is opposed to freedom of composition, the agreement which pervades the Gospels is of such a minute nature as cannot be accounted for by tradition. "It extends," as Professor Sanday observes, " to phrases which are mere connecting links between the sections, and which are just of a kind that on a purely oral tradition would be the first to vary." 22 2. It is difficult to suppose that in a general oral Gospel which dwelt on the actions and discourses of Jesus, the account of the ministry in Jerusalem, as given in the Johamnine narrative, would be entirely absent. The ministry of our Lord in Judæa would have occupied in an oral tradition, if not so large a space as the ministry in Galilee, owing to the shorter period of time which it embraced, yet a proportionate space. 3. The specimens of the teaching of the apostles which we have in the Acts do not bear out the supposition that their teaching consisted almost entirely in the narratives of Christ's life or in the repetition of His parables and discourses. In the discourses of Peter, Stephen, and Panl, as recorded in the Acts, we find that these preachers dwelt almost entirely on the advent of Christ, on His sufferings and death, and

1 "At bottom all the Gaspels rest on oral tradition or aneedotal reminiscences." Holtzmann, Einleitung, p. 340.

${ }^{2}$ Smith's Dictionary of the Bible, 2nd ed. 1. 1220. 
especially on the erowning miracle of His resurrection, as the anthorisation of His mission, without mentioning the particulars of His life. And the same remark is true of the Epistles of the several writers: there are in them few traditionary sayings of our Lord. The record of the life of Christ gathered from the speeches and Epistles of the apostles is surprisingly meagre.

An important modification of this theory was made by Dean Alford, which lessens, if it does not remove, many of the objections brought against it. He supposed that besides the mere oral Cospel, which had in a measure beeome stereotyped, there were also written statements embracing both the incidents in the life of Christ and His teaching, and that these were independently used by the evangelists, and, it may be, incorporated in their Crospels. "I maintain," he observes, "the probability of a very early collection of portions of such oral teaching into documents, some of which two or three of the evangelists may have used." 1 This combination of traditional narratives with written docmments would aceount for the identity of the expressions frequently used by the evangelists.

\section{C.-TIE TIEORY OF AN ORIGINAL DOCUMENT OR DOCUMENTS.}

Aceording to this theory, there lies at the foumdation of the Cospels an original document or documents, which all the three evangelists made use of in the eomposition of their writings; the somree of the Synoptie Gospels is not so much oral tradition as witten doemments. We learn from the prologne to Luke's Gospel that many such writings, purporting to eonvey a narrative of the life of Christ, or giving a collection of His discourses, did exist in the early days of Christianity (Luke i. 1-3). Luke loes not pass any approval or disipproval of such doements, he merely testifies to their existence. This theory of an original docmment or doeuments is the prevalent theory in the present day, and has given rise to a great number of suppositions.

Eichhorm, at the close of last eentury (1794), was the 1 Alforl's cirel Testament, vol. i. Prolegromena, 1. 11. 
first to give prominence to this theory. ${ }^{1} \mathrm{He}$ gave great offence by the boldness of his criticism, coming into direct collision with the then traditional view of the Gospels as independent narratives. At the time the work was regarded as a direct attack on the genuineness and credibility of the Gospels. $^{2}$ He supposed that there was an original Aramaic Gospel, which lay at the foundation of the Synoptic Gospels. This document was soon translated into Greek. In process of time additions were made to it and inserted in the narrative. There were three translations and three sets of traditions, and these constituted the Gospels of Matthew, Mark, and Luke. In addition to this original Aramaic Gospel there was another document containing a collection of precepts, parables, and discourses delivered by Christ, which was used by Matthew and Luke, and accounts for the similarities in their Gospels. ${ }^{3}$

Bishop Marsh adopted this theory of Eichhorn, and endeavoured to improve it. He gives the following statement of his theory: "Matthew, Mark, and Luke used copies of the common Hebrew document, the materials of which Matthew, who wrote in Hebrew, retained in the language in which he found them; but Mark and Luke, besides their copies of the Hebrew document, used a Greek translation of it, which had been made before any additions had been inserted. Lastly, as the Gospels of Mark and Luke contain Greek translations of Hebrew materials which were incorporated into Matthew's Hebrew Gospel, the person, who translated Matthew's Hebrew Gospel into Greek, frequently derived assistance from the Cospel of Mark, where Mark had matter in common with Matthew; and in those places, but in those places only, where Mark had no matter in common with Matthew, he had frequently recourse to Luke's Gospel." 4

${ }^{1}$ Eichhorn's Einleitung in das N.T. vol. i. \$§ 78-88. Le Clere (1716) appears to have been the first critic who suggested it; afterwards it was maintained by Michaelis and Lessing, but it was left to Eichhorn to develop this hypothesis, and to draw it ont into a regular theory.

2 There was certainly some reason for this opinion, as Eichliorn considers that our first three Gospels did not come into use hefore the end of the second century.

${ }^{3}$ Eichhorn's Einleitung, § 84. $\quad{ }^{4}$ Marsh's Michaelis, vol. v. p. 361. 
This hypothesis does not commend itself : it is intrieate and complicated. Besides, it is very meehmical, and makes the evangelists mere eompilers. Although at the time embraced by several eminent erities, ${ }^{1}$ it is now as a whole generally rejeeted, though many of its particulars are still adopted: incleed there is often in striking resemblance between it and some of the more reeent hypotheses.

Much more plansible is the theory of Sehleiermaeher.' Insteal of one original Hebrew document lying at the foundation of the several Gospels, he supposes that there were several doemments. There must have been, at an early period, many evangelieal fragments dispersed throughont the Clnuches, - traditions floating about,- of which writings had been made. These the evangelists worked into their Gospels, along with materials which each had himself collected; and in this mamer Schleiermacher aceounts for the coineidenees and differences. "Why," he asks, "should the harmony of the three evangelists admit of no other explanation than that they either borrowed from each other, or drew from one eommon somce. Subsequently, at all events, there appear several common sourees. Why should we not content ourselves with a plurality of them from the begimning, as some eminent critics have done? For, in itself, surely this oftenrepeated alternation of common and peculiar portions of history points to nothing else than the previons existence of several sonrees, some of which the evangelists had in conmon, some not." 3

Heinrich Ewald supposes that there were nine distinet elements which enterel into the formation of the synopties. The first was an original Gospel, containing a hrief aceount of the chief events of Christ's life from His battism to His deatl, used by l'aul, and which he strangely attributes to

1 Especially by Bertholdt of Erlangen in lis Mistorisch-Kritische

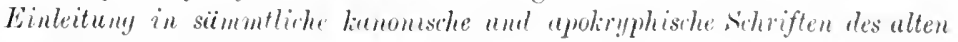
und. neuen T'stuments.

2 See schleiermacher, Commentary on St. Luke, and a valuahle introduetion to it ly the translator, Jishope Thirlwall.

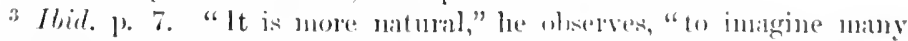
cireumstantial memmials of atached incidents, than a single enmeeted but scanty narrative." 
Philip the deacon. The second is the collection of our Lord's sayings made by Matthew, as mentioned by Papias. The third is Mark's Cospel, made up of these two. The fourth is what he calls "the book of the higher history," being an enlargement of the original Gospel. The fifth is our canonical Gospel of Matthew, based upon the preceding writings. The sixth, seventh, and eighth are three lost works-detailed accomnts of special events in our Lord's life. The ninth is the Gospel of Luke, based on all the other documents, with the exception of the fifth document, namely, the Gospel of Matthew. ${ }^{1} \quad$ Such a theory, though ingenious, is very fanciful, and without much ground to rest upon.

Dr. Edwin Abbott has brought forward a new theory. He marks all those passages where Matthew, Mark, and Luke agree, which he calls the common or triple tradition. ${ }^{2}$ This tradition constitutes a kind of narrative; and this he supposes to have formed the original Gospel, from which the three evangelists borrowed independently of each other. "Is it not possible," he observes, "that the condensed narrative which we can pick out of the three Synoptic records represents the 'elliptical style' of the earliest Gospel notes or Memoirs, which needed to be expanded before they could be used for the purposes of teaching, and which might naturally be expanded with various and sometimes divergent amplification?" 3 According to this theory, the Gospels are independent expansions of notes taken down of the teachings of the apostles. Such a hypothesis has met with no favour from any critic. ${ }^{4}$ It does not account for the twofold tradition of Matthew and Mark, of Mark and Luke, and of Matthew and Luke; whilst it leaves the diversities found in the Gospels without explanation.

There is one other theory which, on account of its ingenuity, plausibility, and originality we would not omit,

${ }^{1}$ Bleek's Introduction to N.T. vol. ii. Pp. 256, 257.

${ }^{2}$ Article on the Gospels in the Encycloped lia Lritannica; Abbott and Rushbrooke, Common Trultition of the Synoptic Gospels.

${ }^{3}$ Abbott and Rushbrooke, p. 11.

${ }^{4}$ For adverse remarks on the hypothesis of Dr. Abbott, see Salmon, Introduction to the N.T. p. 177. It is in its main features a revival of the hypothesis of Eichhorn. 
that of Mr. Smith of .Jordambill. ${ }^{1}$ He supposes-(1) That several of the apostles, especially Matthew, Peter, and John, committed to writing accounts of our Lord's life, in the Aramaic language. (2) That Matthew drew up, from the original Memoirs a life of Christ, both in Hebrew and in Greek. (3) That Luke composed another life, founded upon the authority of eye-witnesses and ministers of the word, including the Hebrew Memoir of Peter and the Greek Gospel of Matthew. (4) That after Peter's death, Mark translated the Memoir written by Peter into Greek. ${ }^{2}$ This hypothesis he illustrates in a most ingenious manner. He takes three histories of the Peninsular War--those of Suchet, Napier, and Alison. Suchet's history was the testimony of an eyewitness, and was translated into English, and used both hy Napier and Alison; whilst Napier's history was known and made use of by Alison. He places three quotations from their histories in parallel columns, showing the remarkable resemblance between them-a resemblance containing sometimes a sameness of expression in all three, and at other times extending only to two of the histories. ${ }^{3}$ He draws a parallel between these resemblances and the resemblances in the three Gospels, and in this mamer explains their verbal coincidences. Certainly the parallel is very striking in these histories; there is the same mixture of variety and identity of expression as is found in the Gospels.

liecently much has been made of the theory of an original Aramaic or Hebrew docment lying at the root of the Synoptic Gospels. This theory has heen unfolded in several interesting and valuable articles by L'rofessor Marshall in the Exppositor, ${ }^{4}$ ind especially by Resch in his work, entitled, The Agrapha. ${ }^{5}$ It is in some respects a revival of Eichhorn's

1 Dissertation on the Origin and Connection of the Gospels; the anthor of that elasional work, The Foygeye of St. Paul.

${ }^{2}$ Ihid. 1. xxy. 3 Thid. pl' xxix.-xxxi.

4 These articles are to be fomd in the Expositor for the year 1891.

s"This is a work of enormous lalomr and arulition, the result of

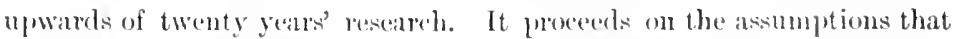
there was an original Gospel in the Helorew langurge, that this was chiefly compered of the siyings of our Iorrl, and that it not only formed one of the matin sources of our Synoptics, lut was used by Paul and quoted hy him. 
theory, though not so mechanical and rigid in its nature. These writers suppose that there was an original document, an Ur-Evangelium, written according to Professor Marshall in Aramaic, and according to Resch in Hebrew. This document was used by all the evangelists. The variation in the words and clauses in the Gospels is accounted for by the different translations given to the Aramaic or Hebrew words. Both Professor Marshall and Resch give examples of how this may be done, and, if the vowel points are neglected as not belonging originally to the languages, how variations in the sense might easily have occurred. Resch gives a list of fiftynine cases in point, where, as he supposes, Hebrew words in the original document are translated by different words in our Gospels. ${ }^{1}$

This theory, if admitted, certainly accounts in many instances for variations in expression; but, when put to the test, it leaves most of these variations unexplained. It is, indeed, asserted by the Fathers that Matthew wrote his Gospel in Hebrew; ${ }^{2}$ but the Gospel, to which these critics allude, is an entirely different Gospel from our canonical Matthew: it is an Aramaic Gospel which lies at the foundation, not of Matthew only, but of all the three Synopties.

\section{D.—THE TWO DOCUMENT THEORY.}

According to this theory, not one but two documents form the main sources of the Gospel narrative. One document is a narrative of the events in the life of Christ-a statement of His actions, and the other is a collection of His sayings-a statement of His discourses. This hypothesis, it is supposed, affords a complete solution of the Synoptic problem. "The narrative of events" accounts for the great sameness of the incidents recorded by all three evangelists;

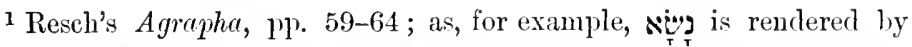

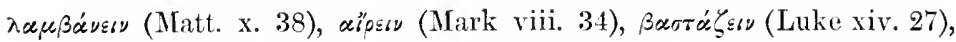
in the same address of our Lord to Hin disciples that they must take "l' His cross.

2 The language in which Matthew's Gospel was written is the subject of future discussion ; so also is the "Gospel accortling to the Hebrews." 
whilst "the colleetion of sayings" accounts for the striking resemblance in the expressions employed. But although this hypothesis is apparently simple, it is in reality highly complieated, and has given rise to great differences of opinion and to several distinet theories.

This hypothesis is supposed to be supprorted by the statement of I'apias, where, aceording to those crities who adopt this theory, these two doeuments are mentioned. Papias first atfirms of Mark's Gospel, on the authority of John the Presbyter, that "Mark, having beeome the interpreter of Peter, wrote down accurately, though not in order, whatever he remembered of the things said and done by Christ, and that he followed Peter, who adapted his teaching to the needs of his hearers, but with no intention of giving a comnected aceount of our Lord's discourses." In this record, containing the preaching of Peter, edited by Mark, we have one of these fundamental documents, whether this be the canonieal Gospel of Mark or a previous Gospel (Ur-Marcus), from which our eanonical Mark is derived." Concerning Matthew, Papias writes: "So then Matthew wrote the oraeles ( $\lambda$ ó $ı$ ı) in the Hebrew language. ${ }^{3}$ In this collection of the $\lambda$ ó $ı$ a of Christ made by Matthew we have the other primary doeumentwhether this is the canonical Gospel of Matthew or a primary Gospel (Ur-Mattheus) nsed by some unknown person in the composition of our Matthew, and also used by Luke in the composition of his Gospel.

This hypothesis of two documents has been adopted by Reuss," Weizsïcker,, Holtzmamn, Weiss, Wendt, Beysehlag,"

1 Ensebins, Hist. Fecl. iii. 39 ; see supre, p. 19.

"Dr. Simdiay remarks: "It is not improhahle that our St. Mark is rescender from a copy which did not exactly reperduce its predecessor,

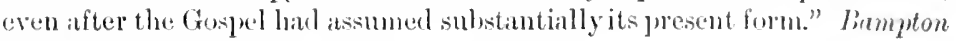
Lectures, ]. 295 .

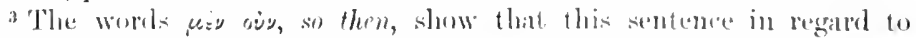

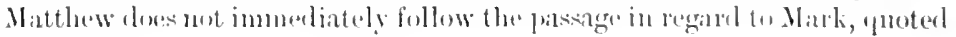
alove.

4 Thistory of the Nere Testement.

"Apost. Zeitulter and Untersuchungen iiber die remgelisthe Geschichte, ihre Quellen whel aler Ging ihrer Eintwickluny.

"Leben Jesn. 
Resch, Dr. Paul Ewald, Pfleiderer, ${ }^{1}$ Sanday, and other recent writers on the Synoptic problem. "All things considered," observes Holtzmann, "the two sonrce hypothesis appears the most probable solution of the Synoptic problem."

Dr. H. Holtzmann of Strasburg, who is regarded as the great anthority on the Synoptic question, and has devoted much attention to the subject, supposes that these two documents - the recort of the preaching of Peter given by Mark, and the Logia, or the collection of the sayings of our Lord compiled by Matthew-were the main sources of the Synoptic Gospels. He supposes the first document to be, not the canonical Gospel of Mark, but an earlier document (UrMareus), fuller than the present Mark; and the second document to be, not the canonical Gospel of Matthew, but a collection of the discourses of Christ compiled by the Apostle Matthew (Ur-Mattheus). The canonical Mark is a revision of the Ur-Marcus, without any intermixture of the Logia of Matthew; whilst the canonical Matthew and Luke are formed from both documents, and from other written and oral sources. Recently Professor Holtzmann has somewhat modified and altered his views, and supposes that Luke had access to the canonical Gospel of Matthew, and made a free use of it, and, consequently, that all the discourses in Luke's Gospel need not necessarily be referred to the Logia; and he observes: "So that at least most of the reasons for distinguishing between an Ur-Marcus and the present Mark have been removed." :

The view of Weiss of Berlin differs from that of Holtzmann as to the prominence to be given to Matthew. He supposes that Mark not only used the "notes of Peter's preaching," but had also access to the Logia collected by Matthew. According to him, "the Logia of Matthew" is the oldest Gospel, and next to it is the Petrine Gospel, or the tradition transmitted by Mark from Peter's preaching. All three Gospels are composite, and these documents were used in

${ }^{1}$ Gifford Lectures, vol. ii. p. 27.

2 For Holtzman's views, see Die Synoptischen Evangelien, 1863 ; Einleitung in das N.T. 1885; commentary on the Synoptic Gospels, Die Synoptiker, 1889. 
different proportions. The original Gospel was a Matthew (Ur-Matthæus), containing the Logia, with a sniall number of incidents. The canonical Mark is a combination of the Memoirs of Peter and a portion of the Logia of Matthew: the canonical Matthew and the canonical Luke are dependent on Mark and on the Logia. ${ }^{1}$

Wendt, of Heidelberg, also adopts the two document hypothesis. He asserts the priority of Mark to Matthew and Luke, and supposes that the series of narratives reported by Mark consists chiefly of the oral evangelical discourses of Peter. Both Matthew and Luke used Mark's Gospel. The Logia of Matthew lies at the foundation of the Gospels of Matthew and Luke, and Wendt attempts the reconstruction of the text of the Logia from these Gospels. He restricts the Logia to the discourses of Jesus. ${ }^{2}$

Resch, in his Agrapha, maintains the following points:1. The priority of the Gospel of Mark. 2. The existence of a Hebrew original Gospel containing chiefly the discourses of Jesus, written before the canonical writings, and lost at an early period. 3. The two docment hypothesis. From these two documents-the Gospel of Mark and the pre-canonical Gospel-the first and third canonical Gospels were chiefly composed. 4. The secondary character of the first Gospel. The Gospel of Matthew is in no sense an original Gospel, also not is translation of the original Hebrew Gospel ascribed to that apostle, but a combination of Mark's Gospel with a Hebrew (rospel sonree, and that by an author who personally was not an eye-witness, but was in a position to and several traditionary facts to the two chief sources. 5. The use of the pre-canonical Gospel of Mark. ${ }^{3}$

Dr. Sanday of Oxford, in a series of valuable articles in the Expositor, ${ }^{4}$ and in his elaborate artiele on the Gospels in the new edition of Snith's Dictionary of the Bible, gives what is the present state of the Symoptic problem. He himself adopts, or, at least, greatly favours, the two document hypo-

1 For Weiss' views, see Mas Mareus Exunglium und seine Symoptischen I'arallelen, beten Jesu, and kinleitung in dus N.T.

2Wenrlt's Dic Lehre Jesu.

3 Resch's A!ruphu, 1. 27.

1 Errpositur for the year 1891 , fonth series, vol. iii. 
thesis. He considers the following particulars as practically proved:-1. That there was a fundamental document. 2. That it is represented most nearly by the Gospel of Mark. 3. That it is highly probable that the common foundation of the three Gospels was a document, strictly so called, written, and not oral. 4. That the exact relation of this document to our present Mark must be regarded as still an open question. ${ }^{1}$ With regard to the second document, or the Logia of Matthew, Dr. Sanday thinks that it was chiefly restricted to the sayings of Christ, and that these sayings or discourses were employed in the first and third Gospels. He considers that the Apostle Matthew did not write the first Gospel as we have it, but that it was called by his name, because it contained the Logia collected by him, a section so important that the name passed from that to the whole. ${ }^{2}$

One great point of dispute regards the meaning to be affixed to the term $\lambda$ ó the writings of Matthew,- - whether it is to be restricted to the sayings and discourses of Jesus, or whether it also includes the incidents of His life. The critics above mentioned, as Holtzmann and also Meyer, restrict the term chiefly to the sayings of Jesus; whilst other critics, as Bleek and Zahn, assert that it was not so restricted, but included the whole life of Jesus-His actions as well as His discourses. This opinion has also been maintained by Bishop Lightfoot. ${ }^{3}$ The term in the New Testament is used for the Scriptures (of course, of the Old Testament), and is not restricted to mere sayings. Thus Paul, speaking of the privileges of the Jews, says that unto them were committed "the oracles of God " ( $\tau \grave{a}$

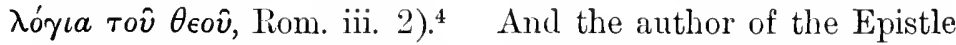
to the Hebrews refers to "the first principles of the oracles of God" (Heb. v. 12). In both passages the reference is to the Scriptures of the Old Testament. ${ }^{5}$ The word, then, as applied

1 Expositor, vol. iii. fourth series, p. 180.

${ }^{2}$ Tbid. p. 303.

${ }^{3}$ Essays on Supernatural Religion, 1'1. 173, 174.

4 See Philippi, Commentary on the Romans, vol. i. p. 105, translation.

5 The word occurs only in two other jassages in the New Testament, and there also the reference appears to be to the Scriptures of the Old Testament, Acts vii. 38 and 1 Pet. iv. 11. 
to the New Testament, would be nearly equivalent to $\epsilon \dot{v} a \gamma \gamma \hat{\epsilon} \lambda_{\iota o \nu}$; and in this sense it is used by the early Fathers. ${ }^{1}$ "There is nothing," observes Bleek, "in the manner in which Papias expresses himself to justify this supposition (namely, that the expression simply refers to a writing wherein Christ's discourses only were collected); he would certainly have expressed himself as he does, if he meant an historical work like our New Testament Gospels, if he were referring to a writing the eontents of which were those of our Greek Gospel

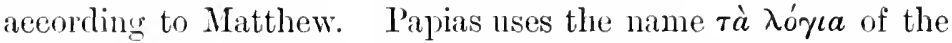
entire Crospel, without making any distinction between the historical narrative and the discourses of Christ." 2

Some progress in the solution of the Synoptie problem has been made. It is now generally agreed by those crities who have studied the question, that the Gospel of Mark, or a writing elosely resembling it, and a collection or collections of the sayings of Jesus, are among the main somrees of the Synop,tie Gospels. A theory which embraces these two points, forming a modifieation of the two doeument hypothesis, is now regarded as the probable solution of the Synoptic problem.

1. The eanonieal Gospel of Mark, or at least a doeument elosely resembling it, is supposed to be the primitive or original Gospel-one of the main sources of the Gospels of Matthew and Luke-used by them either direetly or indireetly. For reasons alrearly stated, we inferred the probability that the first and third evangelists were eognisant of the writing of the second. In order to remove certain diffieulties, to which we have alrealy alluded, attending the assumption of the use of Mark's Crospel by Mattlew and Luke, sone crities aftirm that not our eanonieal Mark, but an original Mark, an Ur-Marens, of which our Mark is a recension, containing a narrative of our Lorrl's life, is the eommon foumlation of the three Synopties. ${ }^{3}$ Some sulpose that the original Mark was of larrer conn pass than the present Mark, and embraced those

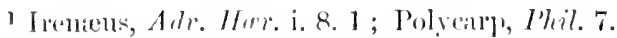

2 Blecek's Introntuction to the N.T. vol. ii. pr). 109, 110.

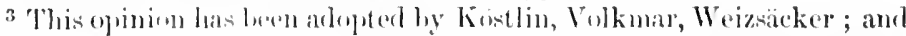

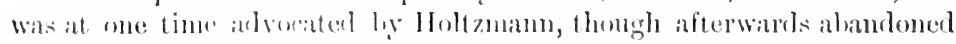
liy him. 
seetions in which Matthew and Luke agree almost verbatim. Others think that it was shorter. Those who do so, argue that the statement of Papias, that Mark wrote down accurately though not in order (ov $\mu \dot{e}^{\prime} \nu \tau o \iota \tau \boldsymbol{a}^{\prime} \xi \epsilon \iota$ ), that is, not eonsecutively, is only suitable to a shorter Gospel than that which we now possess, inasmuch as the canonieal Gospel of Mark is generally considered the most systematie of the three Synopties.

But, so far as we can see, there exists no reason for this supposition. The Fathers mention no such previous Gospel. They speak of the Gospel of Mark, but never indicate that this was only an edition or recension of a former Gospel now lost. Papias distinetly asserts that Mark wrote his Gospel from the teaching of Peter; and Irenæus affirms that the second Gospel was written by Mark, the disciple and interpreter of Peter. The substitution of the canonical Gospel of Mark for a lost Gospel must have occurred either before Papias wrote (A.D. 116) or between the time of Papias and Irenæus (A.D. 180). It could not have occurred before the time of Papias, for there is not the least indication given by him of a previous Gospel, and the time between the eomposition of the Gospel of Mark and Papias is too short to admit of a silent, unnoticed substitution of one Gospel for another. Still more incredible is it to suppose that it disappeared after Papias wrote and before Irencus composed his work against heresies; for we have an almost unbroken ehain of testimony between these two periods, alluding to the Gospel of Mark; so that the Gospel mentioned by Papias could not possibly have been superseded by a different Gospel, without some statement or intimation of this fact in the writings of the early Fathers. ${ }^{1}$ We conelude, then, that our eanonical Gospel of Mark, as we have it, is the primitive Gospel which the other two evangelists saw and used, and which was one of the chief sources of their Grospels. ${ }^{2}$ The use of this Gospel by Matthew and Luke

1 This argmment against the existence of an Ur-Mareus is well put by Barnes in his Canonical and Uncanonical Gospels, p. 68.

2 This opinion is now adopted by most crities. "The testimony of Papias," olsserves Meyer, "regarding the work of Mark furnishes no reason for regarding this work as different from our second canonical Cospel." Commentury mathere, vol. i. 1. 38, translation. 
accomnts for the similarity of incidents in the three Gospels, and also of expressions where all three agree, and where Matthew and Mark, or Mark and Luke agree.

2. The collection or collections of the sayings of Christ, partly oral and partly written, was the other main source of the Synoptic Gospels. It was most natural, indeed inevitable, that the apostles and early Christians would treasure up the sayings of Christ. These sayings would be often repeated by them in their public assemblies, and become indelibly fixed in their menories, and would soon be reduced to writing. The shorter sayings, as that quoted by Paul, "It is more blessed to give than to receive" (Acts xx. 35), would be retained in the memory; but there would also be written collections of the longer sayings or discourses of our Lord which would be taken down at an early period, before the recollection of them had faded away. We camnot suppose that twenty or thirty years would have elapsed before there were any written documents eontaining the parables of our Lord, or the words with which He taught the multitudes. "A few detached aphorisms," observes Professor Salmon, "of a great teacher may be carried by the memory for some time, and be passed from one to another; but discourses of the length we find in the Gospels would, in the ordinary course of things, have perished, if they had not been from the first either committed to writing or, if committed to memory, kept alive by constant repetition. It is surprising how little of spoken words ordinary memories are able to retain. ... If Boswell has been able to give a vivid representation of Dr. Johnson's Table-Talk, it is because he used to stand behind the chair of the object of his veneration with note-book in hand." 1

Different collections of these sayings would he mate in different localities for the use of different Churehes. Some would be written in Aramaic for the nse of the Hebrew converts, and some in Greek for the use of the Hellenistic eonverts. Such collections of the sayings of Christ, both oral and written, loth in Aramaie and in Creek, would be used by all three evangedists in the composition of their cospels.

1 Intronluction to the New Testament, 1. 137. 
This hypothesis accounts for the similarity, often amounting to identity of expression, found not only in all the three Gospels, but especially in the Gospels of Matthew and Luke. Thus, for example, the thanksgiving of our Lord to the Father, when the disciples recorded the suecess of their mission, found in almost identical words in the Gospels of Matthew and Luke (Matt. xi. 25-27; Luke x. 21, 22), is one of those sayings of Christ which these evangelists incorporated in their Gospels. We have already seen that the identity of expression occurs chiefly in the sayings or discourses of Christ. It has been objected that no snch collections of sayings are mentioned by the early Fathers. But their existence was inevitable; the early Christians would feel constrained to collect the words of the Lord, and their incorporation into our Gospels may account for their disappearance. Besides, we do not suppose that there was any single authorised document containing the sayings of Christ, but only that fragmentary writings or detached narratives were dispersed throughout the Churches. We do not consider that the Logia of Matthew, mentioned by Papias, was one of these collections of sayings, because, as we have already observed, the term $\lambda$ ó used in a restricted sense; but, at the same time, it must be admitted that the Gospel of Matthew is remarkable among the other three Gospels for its collections of the sayings of Christ.

We do not know whether these collections of the sayings of Christ entirely disappeared in the apostolic age in eonsequence of their incorporation in the written Gospels. A collection of sayings attributed to our Lord, not recorded in the Gospels, but dispersed through the writings of the early Fathers, and preserved in the apocryphal writings, has been made by Bishop Westcott. ${ }^{1}$ Wendt, in a valuable appendix to his Die Lehre Jesu, adverts to several indications of the words of Jesus in the Epistles of Paul; for example, he adduces the command of the Lord, that the wife should not depart from her husband (1 Cor. vii. 10); the injunction of the Lord, that they which preach the gospel should live of the

1 Westcott's Introluction to the Study of the Gospel, 1st ed. Appendix C, 1.p. 424-438. 
gospel (1 Cor. ix. 14); the institution of the Lord's Supper (1 Cor. xi. 23-25); and the annomeement of the second coming of the Lord, which Paul introduces with the words: "This I say unto you by a word of the Lord" (1 Thess. iv. 15). Resch in his great work, the Agroplea, supposes that "sayings of Christ," contained, as he thinlis, in the Logia of Matthew, written in the Hebrew language, are to be found in the Epistles of Paul and other canonical writings, as well as in the writings of the Fathers. He gives a list of sixtytwo Logia found in the eanonical Epistles and in the writings of the Fathers, which he considers to have been the words of Christ-Agrapla not contained in the Cospels. ${ }^{1}$

We shall, when we come to the investigation of the three Synoptic Gospels separately, consider at length the sources from which each Gospel is derived; but it may be advisable before we close this discussion to advert to these sources in a general mamner.

Many suppose that the Gospel of Matthew is a compilation, and that Matthew's name is attached to it because he wrote a section so important that his name passed from that to the whole; an opinion which we shall afterwards consider. The sources of Matthew's Gospel, according to our hypothesis, are the Cospel of Mark, the sayings or discourses of our Lord either handed down by tradition or in written fragments, and Matthew's own personal observation as an apostle, and his communications with his fellow apostles - of those who were "eye-witnesses and ministers of the word."

Papias, on the authority of John the I'resbyter, informs us that Mark, being the interpreter of Peter, wrote down whatever he (l'eter) remembered of the things said or done by Christ: nor is there any reason to disererlit this statement, as it is confirmed and attested by the Fathers. But, besiles the oral teaching of Peter, the general oral tradition of the Church would form another source of Mark's Gospel. Mark appears to have been a native of . Terusalem, and to have been intimately commeted with the alpstolic Chmeh.

Lnke, in his preface, informs us how his crospel was

'The most remarkahle of these fomel in the Epistles of Panl are 1 Cor. ii. 9, vii. 10, ix. 10 ; Ellı. v. 14 ; 1 Thes. iv. 15 ; 1 Tim. ․ 18. 
composed. He used his utmost diligence in the collection of authentic facts and sayings of our Lord, "tracing the course of all things accurately from the first." One of the documents which he would employ was the Gospel of Mark. He would, no doubt, make a careful selection of the evangelical fragments in circulation containing the sayings of Christ. He might have learned the account of the birth of our Lord either from the brothers of Christ, or it may be from Mary herself. His intercourse with Paul, and perhaps his residence in Judæa during Paul's imprisomment in Ciesarea, afforded him exceptional opportunities of ascertaining the incidents in our Lord's life. And perhaps also there was an additional narrative or document to which he had access, the so-called great insertion or P'crean section (Luke ix. 51-xviii. 14), which does not appear to have been used by the other two evangelists.

The subject is still beset with difficulties; there are still many points not ascertained or settled; many objections to which no satisfactory answers have been given. Especially the relation of Mark's Gospel to the Gospels of Matthew and Luke requires to be more closely examined. We reject the theories of an Ur-Matthæus and an Ur-Marcus as not supported by the statements of the Fathers, and in themselves improbable. And with regard to the statement of Papias, we do not think that it refers to a previons Mark, or to a document containing a collection of the sayings of Christ by Matthew, but to the canonical Gospels of Matthew and Mark then existing, and which came under his notice. At the same time, we must leave the question concerning the sources of the Synoptic Gospels in a considerable measure unanswered, but we look hopefully forward to a satisfactory solution by future critics.

\section{Interpretation of the Synoptic Gospels.}

In the interpretation of the Synoptic Gospels, as of all other ancient writings, the first prerequisite is to secure as correct a text as the nature of the case will permit. For the attainment of this we have the greatest advantages. 
The materials for forming such a text are numerous: there are more than two thousand manuscripts of the Greek New Testament, besides numerous versions and quotations from patristic writings. Eminent scholars have expended mnch labour in a critical exanination of these materials, and have published carefully studied critical editions of the Greek Testament. Griesbach arranged the different manuscripts into families, and formed a new text on the basis of the textus rcceptus. ${ }^{1}$ Lachmann advanced a step farther, by forming a new text from the most ancient manuscripts, giving no preference to the tcxtus receptus, and thus made it his object to restore the text to the state in which it was in the fourth century. ${ }^{2}$ Tischendorf, by the discovery of numerous manuscripts, especially the Codex Sinaiticus, and by the collation of the most important, formed a text which may be regarded as perfect as can possibly be made, almost a restoration of the originals. ${ }^{3}$ Tregelles, in our own country, carefully collected additional manuscripts, and published a Greek Testament, vying in accuracy with the editions of those illustrious German scholars. ${ }^{4}$ And Westcott and Hort, profiting by the labours of their great predecessors, conjointly published a critical edition, ${ }^{5}$ which by many is considered as a standard work, almost rendering all additional research unnecessary, unless new materials for cxamination should be discovered. The result of these investigations has been thus stated by Dr. Hort, in terms certainly not too strongly expressed: "In the variety and fulness of the evidence on which it rests, the text of the New Testanent stands absolutely and mapproachably alone among ancient prose writings." 6

1 Grieshach, Novum Testumentum grece, Londini, 1818.

2 Lachminn's Norum Testementum grace et lutine, Berlin, 1832.

3 'Tischentorf, Norum Testamentum yrece, editio septima, Leipsic, 1889 ; editio octava, 1873.

4 'Tregelles, The Grek New Testement, edited from ancient anthorities with their various realings in full, London, 18.7-1879.

5 The New Testement in the orifinal (ireck. The text revised hy Dr. Westcott and Dr. Ihort. By the reeent death of 1)r. Itort, the Churels of Englaml lost (ne of its ablest scholin's, and one of the anos amialle of men.

"The manuscripts of the New Testament are divided into two clisses, those written in meial characters, which are the most ancient, and those 
Having obtained a correct text, the next task is to translate it. Whatever modification the element of inspiration may necessitate in giving to the text a higher and more spiritual meaning, yet, in the first instance, the ordinary methods of interpretation must be employed to ascertain its literal sense. As the late Professor Jowett observes: "Interpret the Scripture like any other book. There are many respects in which Scripture is unlike any other book; these will appear in the results of such an interpretation. The first step is to know the meaning, and this can only be done in the same careful and impartial way that we ascertain the meaning of Sophocles or of Plato." "Scripture is to be interpreted like other books, with attention to the character of its anthors and the prevailing state of civilisation and knowledge, with allowance for peculiarities of style and language, and modes of thought and figures of speech." 1

written in cursive characters, which are the most recent. No manuscript has been ciscovered older than the fourth century. Of ancient manuscripts there are five which have pre-eminence on account of their age and the consequent value of their readings; these are the Codex Sinaiticus (N), discovered by Tisehendorf, and now in St. Petersburg; the Codex Alexandrinus (A), now in the British Museum; the Codex Vaticanus (B), now in the Vatican; the Codex Ephræm (C), a palimpsist, containing fragments of the New Testament, now in the Imperial Library of Paris; and the Codex Bezae, now in the University Library of Cambridge. Perhaps Westcott and Hort, in their eritical edition, have ranked too highly the Sinaiticus and the Vaticanus to the disparagement of the Codex Alexandrimus. The cursive manuscripts are much more numerous than the uncial; and it has been thought by Dean Burgon, Canon Cook, and others, that their value has been underestimated, and an undue preference given to the uncial, inasmuch as many of these cursive mannseripts are doubtless transeripts of older manuscripts than any which we possess; but as it is impossible to prove this, the only course left open to us is to form our text chiefly from the readings of the most ancient codices. Of the versions of the New Testament the most valuable are the Old Latin and the Syriac, both of which were formed about the middle of the setond century, and thus contain readings older than those of our oldest Greek manuseripts. The quotations from the Fathers are for critical purposes of inferior value, unless on those rare vecasions when a peculiar reading is mentioned, because most of these yutations were made from memory.

1 Jowett's essay on the Interpretation of Scripture in Essays and Reviews, 8th ed. pp. 377, 404. The whole essay is well worthy of a careful perusal; some of the statements are of donbtful tendency. 
The result of all these seholarly investigations has in our age been the publication of the Revised Tersion, a work which occupied for several years the attention of the most distingnished biblical seholars, both of this country and of America. It has not, it must be admitted, answered the expeetations either of those engaged on it or of its admirers. The Authorised Version has not, as was fondly expeeted, been superseded by it, nor are there any symptoms of this ever being the case; yet it is a great gain to Christians in our country, and a great advantage to biblical seholars. The translation possesses the weight of authority. It is formed on the most approved text, the nearest approach that has yet been made to the original, and hence several passages which are inserted in the Authorised Version are now, after a careful examination of authorities, regarded as interpolations, and a few which were omitted are now inserted as genuine. The chief omissions are the doxology to the eonclusion of the Lord's Prayer (Matt. vii. 13), and the testimony of the heavenly witnesses ( 1 John v. 7 ); in 1 Tim. iii. 16 , He is substituted for God; whilst the incident of the woman taken in adultery (John viii. 1-11), and the conchuding verses of Mark's Gospel (Mark xvi. 9-20), are marked as doubtful. The additions to the Authorised text are few ; in 1 John ii. 23 , the elause: "He that confesseth the Son hath the Father also," is no longer printed in italics, as if it were doubtful. The translation is also distinguished for its accuracy; and thus many obseure passages are elucidated, and many misapurehensions corrected. The great fault of the Revised Version is that it often departs unneeessarily from the fine old English of the Authorised Version, which has endeared itself to the hearts of the people, and has had almost a sanctity imparted to it. Some of the alterations are also of doultful advantage, as the sulsstitution of "the evil one" for "evil" in the petition in the Jord's Prayer: "Deliver us from evil."

A number of words used in the synoptie Cospels may be considered as translations either from the Hebrew or from the Aramaice. We have already alluderl to the hypothesis of a Hebrew or Aramaic Cinspel, advanced by Professor Marshall and Tieseh, as one of the main sources 
of the Synoptics. ${ }^{1}$ But although we do not think that there is much or any ground for this hypothesis, yet we have the testimony of Papias, followed by many of the early Fathers, that Matthew wrote his Gospel in Hebrew. This important statement will afterwards be considered; but, if we admit its truth, it follows that the Gospel of Matthew, as we now have it, is a translation from Aramaic or Hebrew into Greek. There may also have been Gospel-fragments in Hebrew used by all three evangelists. If this is the case, it would account for many verbal variations which oceur in the Synoptics, in describing the same events and recording the same discourses. As already olserved, it never happens that two translators of a passage use precisely the same words; and this is especially the case when translating from the Hebrew and Aramaic, owing to the peculiarities of these langnages with regard to their vocalisation ; the omission or change of vowel points, which are of comparatively recent origin, occasions a variation of meaning.

On account of its importance, we repeat what has already been said in our Introduction to the Pauline Epistles, that an essential prerequisite for the interpretation of Seripture, and of the Synoptic Gospels in particular, is candour. This is a quality in which many biblical scholars and exegetes are sadly deficient. From sectarian or doctrinal bias we are apt to err in this particular, and to come to the study of the Synoptic Gospels with preconceived opinions, and seek to read into them our doctrinal views. This is especially seen in the mumerons and conflicting interpretations which are given to the Sermon on the Mount. ${ }^{2}$ We must reverse the process, and come to the study of the Scriptures as much as possible without prepossession; not asserting dogmatically that such must be the meaning of a passage because such are the views we have arlopted; but that such are our views, becanse such is the obvious meaning of Scripture. ${ }^{3}$

1 See supra, p. 60.

2 Besides the interpretations given in the different commentaries, the reader is especially referred to the suggestive views of Count Tolstoi.

3 Introduction to the Pauline Epistles, 1. 54. 
Another prerequisite for the interpretation of the Synoptie Gospels is to put on'selves as much as possible in the times when these Gospels were written. We must acquire a linowledge of the eireminstances of the times, of the political condition of Juctea, of the opinions of the various parties into which the Jews were divided,-the Pharisees and the Sadducees, - and of the feelings which actuated the mass of the people. We must try and understand the disposition of the Jews toward Christ; His popularity with the people at first, and its gradual deeline; and the reason of the hostility of the chief rulers which culminated in His death. ${ }^{1}$ We must, with the spirit of a historian, live over in thought that period. "If," says Cardinal Wiseman, "we wish to understand an author, we must transplant ourselves from our age and country, and place ourselves in the posture of those whom our Saviour addressed. We must invest ourselves with their knowledge, their feelings, habits, opinions, if we wish to understand the discourses which were addressed primarily and immediately to them. For the true meaning of a word or phrase is that which was attached to it at the time when the person whom we interpret wrote or spoke."

It has been objected, that if the evangelists had not written their Gospels independently, but either used each other's Gospel, or incorporated other written documents, or had recourse to oral traditions; especially if there were original Gospels, now lost, that lay at the fomdation of om canonical Gospels, they camnot be considered as inspired: the evangelists are left entirely to the use of their own mental powers, and in many respects are mere compilers. "The inspiration of the Gospels," says Mr. Sadler, "is incompatible with the theory that they were all taken from one ducunnent, for in such a case that unknown anl lost document must have been the only one that could be called the work of the Spirit; and the alterations which each one made in it, which their mutual discrepancies show, prove

I See esprecially on this point the great and exhantive work of Schiiler, The Jerish I'mple in the Time of ('hrist; also Hansw'ath's Mistory of the New Testument Times: The Time of Jewn. 
that in altering it they individually were not so far guided by the Holy Spirit." 1

It is foreign to an Introduction to the Synoptic Gospels to enter into any discussion of inspiration, either in proof of its truth or in explanation of its nature and extent; this belongs to the sphere of dogmatic theology. The inspiration of the Gospels does not affect the mode of interpretation, nor the consideration of the sources from which they were derived. The Gospel-fragments, used by the evangelists, or incorporated into their writings, may have been inspired documents; of course of this we have no direct evidence, except that which arises from the nature of their contents. Luke, for example, in his preface, indicates that he had access to several traditionary accounts or written documents, and among them might be the Gospel of Mark and these Gospel-fragments. The Holy spirit might influence him in the choice of his materials, and might guide and direct him to what was true and important. Our Lord, on the eve of His departure, promised the gift of inspiration to His apostles. The Holy Spirit was to enlighten their minds in the knowledge of the truth, to guide them into all truth, to show them things to come, to reveal those "many things" which Christ had not disclosed, and to assist them in their apologies before kings and rulers. "These things have I spoken unto you, while yet abiding with you. But the Comforter, even the Holy Ghost, whom the Father will send in My name, He shall teach you all things, and bring to your remembrance all that I have said unto you" (John xiv. 25, 26). "When He, the Spirit of truth, is come, He shall gruide you into all truth: for He shall not speak from Himself; but what things soever He shall hear, these shall $\mathrm{He}$ speak: and He shall declare unto you the things that are to come" (John xvi. 13). The Fathers repeatedly assert the inspiration of the sacred writers. Tertullian speaks of them as having their minds flooded with the Holy Spirit; ${ }^{2}$ and Origen affirms that the sacred books are not the works of men, but were written by inspiration of the Holy Spirit. ${ }^{3}$

1 Quvied in Salmon's Introduction to the N.T. p. 156, note. 2 Apol. 18.

"De Princip. iv. 9. It is difficult, if not impossible, to define the 
It has, however, been asserted that there are discrepancies in the Symoptic Grospels of such a nature as disprove their inspiration. Whether these diserepancies exist is one question; and whether, granting their existence, they are of such a character as to disprove the inspiration of the Gospels, is another. We have alrearly admitted, what is indeed mudeniable, that there are great differences in the Gospels, especially in those of Matthew and Lnke, in their narratives of the birth of our Lord, of His sufferings and death, and of His resurrection; and we have lwelt upon these differences in considering the nature of the Synoptic problem. But many of these differences are not inaccuracies or discrepancies, but additions to the history or variations in the statement of the same incidents seen from different points of view. ${ }^{1}$ It is also to be observed that there may have been a repetition of the same incidents. Thus to take a notable example: we learn from Matthew and Mark that there were two oecasions on which our Lord miraculously fed the multitude, with points of similarity and dissimilarity in the aceounts, whilst only one of these instances is recorded by Luke. Now, supposing that Matthew and Mark had only recorded one of those miracles, the feeding of the four thousand, whilst the other miracle, the feeding of the five thonsand, was only recorded by Luke, it would be asserter that there were numerons discrepancies in the accounts of the evangelists; the one account asserting the number of those fer to be four thousand, and the other five thousind; according to the one the supply of food was seven loaves, aceording to the other four loaves and two fishes; the fragments gathered, aceording to one narrattive, were seven baskets full, and according to the other, twelve haskets. Whereas all these discrepancies are at onee

nature of inspiration; and henee in confessions of faith, whilst the inspiration of Seripture is asserterl, it is gemerally left mexplatincel. It implies

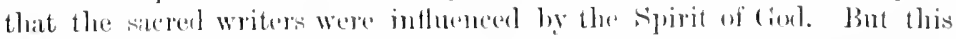
general atsertion does not admit of being particularised. See simday's Liompton Lectures on "Inviration," 1.p. $31 \mathrm{ff}$; Row's Bampton Lectures, 1'] $413-448$.

1 For the consideration of these differences in the symoptic cospels

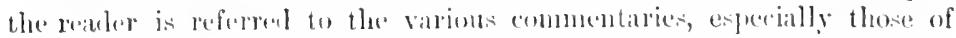
Merer, Gorlet, Alfurd, Horison, M'cledlatn, ete. 
removed and disappear by the information we possess, that our Lord fed the multitude, not on a single, but on two occasions. A similar solution may solve other difficulties; as, for example, in the case of the anointing of our Lord; one anointing is related by Luke (vii. 36-40), and another by Matthew (xxvi. 6, 7) and Mark (xiv. 3). Both agree in the facts that the person who anointed was a woman, and that the name of the person in whose house it occurred was Simon, one of the most common .Jewish names. But in all other particulars they differ essentially; the one occurred during the course of om Lord's ministry in Galilee, the other in Bethany shortly before His passion; in the one case the woman was a penitent sinner, in the other she was the saintly Mary, the sister of Lazarus. All these differences disappear on the reasonable supposition that the anointing occurred on two different oecasions. So also there is nothing improbable in the supposition that the disciples twice disputed among themselves which of them should be the greatest (Luke ix. 46, xxii. 24); and that our Lord twice purified the temple by casting out the buyers and sellers, once at the begimning (John ii. 13-17), and a second time at the close of His ministry (Matt. xxi. 12, 13). Many of the sayings of our Lord might have been repeated, as they partook of the nature of proverbial expressions, as "He that humbleth himself shall be exalted; and he that exalteth himself shall be humbled " (Luke xiv. 11, xviii. 14). "Whosoever shall save his life shall lose it" (Luke ix. 24, xvii. 33). So also mueh of the Sermon on the Mount may have been twice repeated, and our Lord may have given to His diseiples on two oecasions a similar form of prayer. ${ }^{1}$ The alleged discrepaneies in the Gospels are greatly diminished in number by these considerations, and the differences which do still exist are proofs of the comparative independence of the writers;

1 In Mattlew's Gospel, the Lord's Prayer constitutes part of the Sermon on the Monnt, whilst in Luke's Gospel our Lord is represented as giving it in answer to the request of the disciples to instruct them in the mode of pryyer (Lnke xi. 1). There are also considerable verbal viriations in the two forms. See on rloublets in the Gospels, supro, p. 37. 
indeed, the marvel is that so few alleged diserepaneies exist. ${ }^{1}$

There is one incident, however, which requires special consideration owing to the extreme diffieulty of harmonising the aceounts. We allude to the incident of the cure of the blind man at Jericho, as given by all three evangelists (Matt. xx. 29-3t; Mark x. 46-52; Luke xviii. 35-43). In the aceounts given there is a twofold variation as regards the number of those cured, and as regards the loeality where the miracle was performed. Matthew affirms that there were two men, ${ }^{2}$ whilst Mark and Luke seem to intimate that there was only one. Luke tells us that the cure was performed as our Lord entered Jericho, whilst Matthew and Mark say that it happened when He departed from Jericho. The attempted solutions of these diserepancies have hitherto been foreed and unnatural, mere evasions of the diffienlty. M'Clellan supposes that as our Lord entered Jericho two blind men sat by the wayside begging, but made no application; and, on the next day, when our Lord was departing, they eried out, "Jesus, Thou Son of David, have merey on us!" and were cured ${ }^{3}$ which is eertainly at variance with the aeeount given us by Luke. Greswell supposes that two miracles were performed in Jericho, but at different times and on different individuals; that Mark relates one of the miracles performed when Jesus was departing from Jericho, and Luke relates the other as Jesus was entering Jericho, and that Matthew embraces both cures in one narrative. But the language employed by the blind men and our Lord, as recorded by all the evangelists, was the same, thus indicating that the miracle was the same. Surely it is

1 Other apparent discrepancies, as the genealogies, the census of Quirinius, the proplecy of Zechariah referred to Jereminh, are discussed farther on. The diflerence hetween the symoptics and St. John as to the diay of our Lord's death is discussed in the Intruduction to the Johennine Writims.

2 In Matthew's (aospel the number cured is often dombled: as here the two blind menat Jerielo, the two demoniaws at Gadara (Matt. viii. 28), the two blind men at Capermamm (Matt. ix. 2i).

3 M'Clellan's Nem Testement, vol. i. j. 467.

4 (ireswell's /)issertutions, rul. ii. 1. 569. 
better frankly to admit the discrepancy than to have recourse to such forced methods of conciliation. There may be some method of reconciliation of which we are ignorant, owing to the scantiness of our information. Even admitting the discrepancy, it is evidently of a slight nature, and does not at all affect the principal fact, that a miracle of healing was performed at Jericho. ${ }^{1}$

It is an obvious remark, that in interpreting any writing there must be a certain sympathy between the reader and the writing: a poetical spirit can only understand and appreciate poetry; a mathematical mind can only solve the problems of mathematies; a philosophical mind can only follow the discussions of metaphysicians; an historical mind can only fully enter into the great political and social questions of the age. This is especially the case with the interpretation of the Scriptures: the word of God can only be truly understood by a religious mind. There must be an inspiration within us, an indwelling of the Holy Spirit, to correspond with the inspiration of the Scriptures without us. In this sense we may understand the words of the apostle: "The natural man receiveth not the things of the Spirit of God: for they are foolishness unto him; and he cannot know them, because they are spiritually judged" (1 Cor. ii. 14). In order, then, to interpret the Synoptic Gospels aright, to fathom the depth of their meaning, to grasp the fulness of spiritual truth which they contain, we must have spiritual discernment: we must feel the truth in our hearts. ${ }^{2}$

The Synoptic Gospels to the religious mind possess internal evidences of their inspiration; they bear impressed upon them the mark of their supernatural origin. The

${ }^{1}$ See on this suljject some excellent remarks by Row, Bumpton Lectures, pp. 472, 473. Tatian mentions only one blind man, Bartineus, who was cured when Jesus was departing from Jericho.

2 The Scriptures address themselves not so much to man's rational nature, the $\psi$ uxyे, as to man's spiritual nature, the $\pi \nu \varepsilon \tilde{\nu} \mu x$. We require the assistance of a higher spirit than our own, even the Spirit of God, the great Inspirer, to understand His worrl we must be in sympathy with the great Author. There is great truth in Neander's famous adage: Pectus est quod theologum facit. See some excellent remarks on Inspiration in the Westminster Confession, ch. i. 5. 
discourses recorded in them are the words of One who spoke as never man spoke. The parables of our Lord, for example, are full of inspiration. Those wonderful discourses, linking the world of spirit with the world of matter, transfiguring with a divine glory the phenomena of nature, at once so simple and so profound, so natural and so supcrnatural, so many-sided, awakening a response, not merely in the hearts of those to whom they were primarily addressed, but in the heart of humanity, are revelations of the Spirit of God.

So also that wonderful discourse of our Lord to which we have already adverted, the so-called Sermon on the Mount, whether we consider it as given on a single occasion in one discourse as is recorded in Matthew's Gospel, or whether we consider it as given in detached portions on different occasions as related in Luke's Gospel, has been almost universally acknowledged to bear upon itself the impress of inspiration. ${ }^{1}$ It is the most wonderfully inspired discourse that ever was uttered. It is the revelation of the laws of the Gospel-not the destruction, but the fulfilment and completion of the law-rescuing it from the formal interpretation of the scribes and Pharisees, bringing its precepts to bear upon the heart, declaring that it relates not to outward actions, but to the disposition. It is the inauguration of the kingdom of God. There was doubtless, after the completion of our Lord's work by His death and resurrection, and after His departure from the world, a subsequent development of Christianity by the apostles; but the germs are found in this discourse; it is the fountain from which all subsequent streams of spiritual truth have issued. Plato and Socrates never uttered truths so profound, so living, so transforming, so universal in their application, as those given in this discomise by Jesus of Nazareth.

I In all probability the large portion of it given ly Luke, the socalled Sermon on the Plain (Luke vi. 20-49), is identical with the occasion when the fermon on the Mount was delivered. The circumstances attending both discomrses are similar, there heing in hoth cases multitudes of hearers from Galilee and Juldea and from heyomd Jordan ; and the time when they were spoken ippears to coincide. So strond, Tholuck, Ewall, Alford, Worlsworth, Westeott, M'Clellan, and Ellicott. see supra, 1. 39. 
It has been maintained that the Sermon on the Mount and the other discourses and parables of our Lord contained in the Synoptics form the main truths of Christianity - the fundamentals of the religion of Jesus. We have been, it is said, too long deriving our Christianity from the teaching of Paul, we must return to the Christianity of Christ. We must draw the living water, not from the stream, but from the fountainhear. On all sides the ery is: "Back to Christ!" 1 It is from His teaching, as recorded in the Synoptic Gospels chiefly, that we derive our knowledge of the way of salvation. Even the Gospel of John, long regarded as "the spiritual Gospel," as diselosing the heart of Jesus, must, it is said, yield the palm to the Synoptics, and oceupy a secondary place. "The heart of the man Jesus in its rich fulness of grace and spiritual truth, is more adequately shown in the first three Gospels than in the fourth. ${ }^{2}$ And with regard to the Epistles of Paul, the view of Christianity, as there exhibited, nust be regarded as inferior to the revelation in the Synoptic Gospels. "Paul's point of view is individual; Christ's is social." "It is the business of theology to determine the affinities between the Galilean and the Pauhine Gospels, but it is the privilege of religious faith to enter into life by the door which Jesus has opened, without stopping to inquire whether Paul's key fits the lock. The words of Jesus are 'words of eternal life,' and no truth not spoken by Him ean be essential to salvation, however helpful for upbuilding in faith." 3 Even with regard to the death of Christ, whilst Paul insists on it as the great atonement for sin, yet he has not "presented in all its aspects the meaning of Christ's death; he has not tanght with breadth and emphasis the precious doctrine of Christ's temptations and priestly sympathy." 4

Now this exaltation of the Sermon on the Mount and

1 Bruce, The Kinylom of Gorl, 1. 329. See also this thought developed in Principal Fairlairn's recent suggestive work, Christ in Modern Theology.

2 Bruce's Apologetics, 1'l. 485-490. See, on the contrary, Tholuck's Sermon on the Mount, trans. 1. 35; here he states: "In the further" development of Rationalism, the gronnd it took was most plainly inflicated by its preference of the Epistle of St. James to those of St. Paul, and of the Sermon on the Mount to the Gospel of St. John."

3 Bruce's A poloyetics, 1]. 427, 428. 4 Ilicl. 11). 426, 427. 
the Synoptic discourses above other parts of Scripture, appears to us erroncous. Most certainly the teaching of Christ is of primary importance; but it did not contain the full revelation, it was necessarily of a preparatory character. Jesus Himself said: "I have yet many things to say unto you, but ye eamnot bear them now. Howbeit when He, the Spirit of truth, is come, He shall guide you into all the truth" (John xvi. 12, 13). The apostles during the life of their Lord were not capable of receiving the full revelation of salvation; the atoning nature of the death of Christ could not be fully declared until Christ had died and the atonement had actually been made: the Holy Spirit was not given until Jesus was glorified (John vii. 39). He by His teaching laid the foundation of the spiritual temple, but the apostles under the guidance of the Holy Spirit were the instruments employed in rearing the superstructure. Paul and the other sacred writers unfolded truths which Jesus had only revealed in part. They explained the way of salvation more distinctly; the ageney and work of the Holy Spirit was not clearly made known until the outpouring of His influences on the day of Pentecost.

The three Synoptic Gospels have their distinctive peculiarities. There are properly not three Gospels, but one Gospel under different aspects. It is one I'erson who is described; they contain memorabilia of Christ. They are three photographs of one original, shown in different lights, and placed in different positions. Yet there is no unvaried uniformity; the characteristies of each writer are impressed upon his writing: there is no slavish copying of one from the other: inspiration does not obliterate the personality of the evangelists. Matthew, writing to the Jews, dwells upon Jesus as the Messiah; he heaps proof upon proof that the prophecies of the Old Testannent were fulfilled in IIim; he does not dwell so much as the other evangelists on the incidents of our Lord's life, but groups His discourses and gives them in a compact form: he imparts to us the teaching of Him who came to redeen Israel and establish the kingdom of God. Mark, writing perhays to the Romans, dwells upon Jesus as the Imperator, the great King of men, the Son of God: he 
dwells chiefly on His miracles and less on His discourses; he writes with the freshness of an eye-witness, and gives graphic and lifelike descriptions of the incidents he records. Luke dwells on the human nature of Jesus: he discloses His divine compassion and condescension; he describes Him, not so much as the Son of David, but as the Son of Man; he indicates the universality of His mission, and reveals Him as the Saviour, not of the Jews merely, but of the world, as the Friend and Recteemer of the human race. ${ }^{1}$

\section{The Harmony of the Gospels.}

It is natural to endeavour to arrange the statements of the three evangelists into a harmony; to represent the life of Christ as a unity. This was attempted at a very early period. Many suppose that Justin Martyr (A.D. 150) in quoting from the Gospels, as the memorials of Christ, used a harmony. It is certain that shortly afterwards (A.D. 160) Tatian drew up his

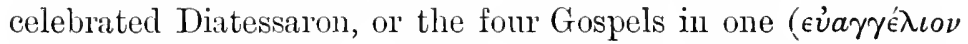
$\delta \iota \grave{a} \tau \hat{\omega} \nu \quad \tau \epsilon \sigma \sigma a \dot{\alpha} \omega \nu) .^{2} \quad \mathrm{He}$ was followed by Ammonius

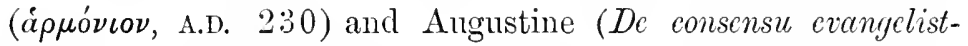
arum). Calvin drew up a harmony of the Gospels in a liberal manner, making full allowance for their variations: according to him, in Matthew the greatest attention is paid to consecutive order; in Luke, the least. Osiander in his Harmonia evangcliorum proceeded on an entirely different principle. His dogmatic assumption was that as the evangelists were inspired, the discourses of Jesus, when there was any considerable difference, must have been repeated, and His actions must have been related in the exact order in which they occurred; hence the same events were represented as having

1 For the distinctive peculiarities of the Gospels, see Ellicott's Hulseun Lectures on the life of our Lord Jesus Christ, Lecture V.; Westcott's Introduction to the Study of the Gospels, Pl. 308-313 ; Fairbairn's Christ in Modern Theology, p1. 334-338.

2 We have now (1894) the great advantage of perusing the Diatessaron of Tatian in a translation from the Arabic, and have to express our high admilation of it. As a harmony it is not inferior to many of modern times. 
happened twice or even three times. ${ }^{1}$ Modern harmonies of the Gospels are exceedingly numerous, and some of them of great value. Greswell's Dissertations upon the principles and arrangement of the Hermony of the Gospels," contain matter of high importance, well deserving of attentive study. stroud, arranging the Gospels in parallel columns, formed out of them a combined Greek text. ${ }^{3}$ Wieseler's S'ynopsis of the Four Gospels, ${ }^{4}$ is ehiefly a series of important discussions on the ehronology of our Lord's life. The value of Rushbrooke's Synopticon has already been adverted to."

But the question meets us: Is a hammony of the Symoptie Gospels possible? If the evangelists do not follow a chronological order, how can we draw up a harmony of their accomnts? Alford denies this possibility, and asserts that all attempts at arrangement are fruitless labours. The endeavon's of harmonists to force into agreement the different accounts, he asserts, have been most prejudicial, and have given ocea-

1 Schaff asserts that according to Osiander, Peter's wife's mother was healed three times.

${ }^{2}$ Pullished at Oxford, 1830.

3 Stroud's Greel: Itarmony of the Four Gospels, London, 1853. This is a work of great lathour and erudition. There is a long introduction or dissertation of 216 pages. Stroud was not a clergyman, lunt a physieilin.

4 Transłated by Venables, Cambridge, 1864.

${ }^{5}$ We give a list of the principal Harmonies of the Gospels given

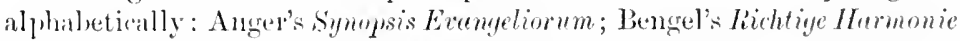

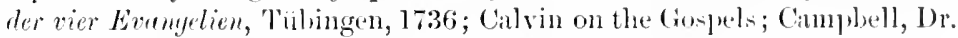
Colin, Greek of the Thre First Gospels, Glasgow, 1882 ; Caspari's Life of Christ, trans. T. \& T. Clark, Edinhourglı, 1876 ; Chemnity, Itermonie

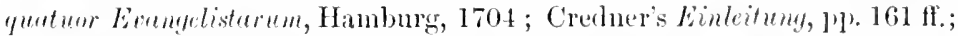

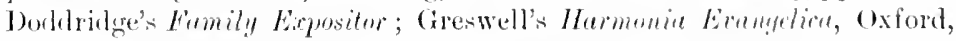
1810; Grieshath, Signowsis Errengelionm, IIalle, 1726; Lightfoot's

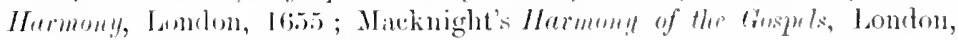

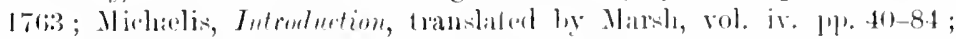

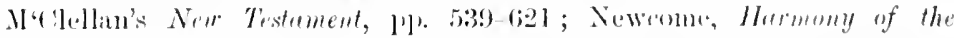

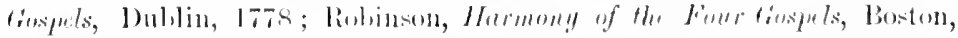

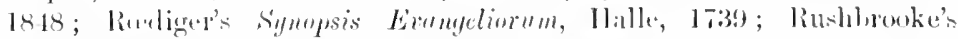

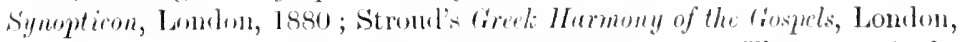

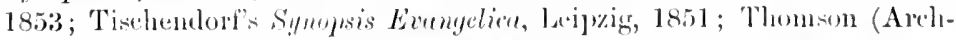

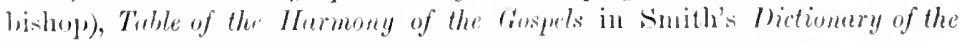

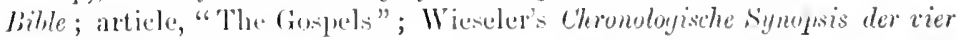
Erengelien, Hatulium, 1843. 
sion to objections to the Gospel narrative. ${ }^{1}$ But although a minute harmony, embracing details, is perhaps impossible, yet there is a general harmony; the great events of our Lord's life can be arranged in the order of their occurrence, although the subordinate events camnot. Luke, in his preface, states that having traced the course of all things accurately from the first, he intended to write them in order ( $\kappa a \theta \epsilon \xi \eta \hat{\jmath} s)$; but this order is only generally maintained. On the other hand, Papias declares that Mark followed Peter, who adapted his teaching to the needs of his hearers, but with no intention of giving a connected account of our Lord's discourses (oن่ $\chi \ddot{\omega} \sigma \pi \epsilon \rho$

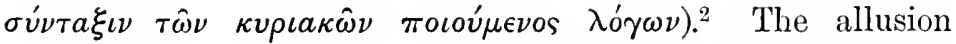
here may be only to our Lord's discourses, and not to the incidents of His life; for it is now generally admitted that the order observed in Mark's Gospel is the most trustworthy. Whilst, then, it cannot be maintained universally that the order of events, as given in harmonies, is chronologically correct, yet there is an undisputed order in which many particulars are recorded. The baptism of John inaugurated the ministry of our Lord, then follows an account of His missionary journeys through Galilee, with the two great crises in His life, the confession of His Messiahship by His apostles, and $\mathrm{His}$ transfiguration; then His entrance into Jerusalem, and the account of His passion. The record of the six days which intervened between His entrance into Jerusalem and His death, can be so drawn up that the events of each day can be recorded with extreme probability. ${ }^{3}$

Until our Lord's last visit to Jerusalem, the Synoptic Gospels are restricted to His ministry in Galilee. The time occupied in that ministry is not stated, and hence the arrangement of these Gospels is not according to time, but according to the special missionary journeys through Galilee. It would appear from these Gospels that three circuits of

${ }^{1}$ Alford's Greek Testament, ch. i. \$ vii., "The practicalility of constructing a formal harmony of the three Gospels."

${ }^{2} \mathrm{He}$ also says that he wrote down accurately, but not in order (oi $\left.\tau \dot{\alpha} \dot{\alpha}_{\xi} \varepsilon l\right)$.

${ }^{3}$ Definite marks of time and place are seldom given; the particles of transition are in general indefinite; and it is only rarely that a connected series of events is recorded. 
Galilee are mentioned, each of them proceeding from and returning to Capernaum. The first circuit was at the eommencement of the ministry, and is reeorded by all the evangelists. They tell us that Jesus went about in all Galilee, teaching in the synagognes, and preaching the gospel of the kingdom, and healing all manner of sickness and all manner of clisease among the people (Matt. iv. 23; Mark i. $35-39$; Luke iv. 42-44). It was at the close of this cirenit that the Sermon on the Mornt was delivered. The second cirenit is most fully recorded in Luke's Gospel, where we read that "afterwards He went through cities and villages preaching and bringing the good tidings of the kingdom of God," accompanied by the women of Galilee, who ministered unto Him of their substance (Luke viii. 1-3). It was during this journey that $\mathrm{He}$ commenced teaching the people by means of parables. The third circuit is mentioned by Mathew and Mark in language preeisely similar to the statement of the first cirenit: "Jesus went through all the eities ancl villages, teaching in their synagognes, and preaching the gospel of the kingdom" (Matt. ix. 35-38; Mark vi. 6). It was dhuing this jouney that He twice performed the miracle of feeding the multitude, and sent forth His apostles to pave the way for His mission; then also the eonfession of His Messiahship by the apostles and the Transfiguration ocemred. Greswell remarks that there are "clear evidences of three general, and, at least, two partial eircuits-the two last of the general and each of the partial within the compass of the sume year, and the first of the general during the six months of the year Jefore." 1 A harmony of the Symoptic Gospels maty be drawn up aceording to these three eirenits and the events stated, which probably oecurred rluring each of thent.

If, however, the Fourth Gospel is taken into account, then the hamony of the Gospels must proceed upon a different principle-not aceording to the cirruits in Galilee, but aceording to the order of time. From John's Gospel we

1 (isenwell's Ihssertutions, vol. ii. p. 343. Shee also for the missionary

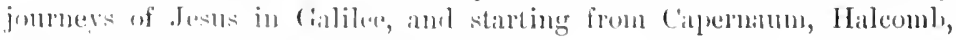

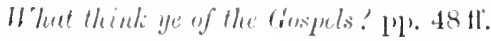


learn that our Lord's ministry must have extended over two to three years, as three Passovers are mentioned (John ii. 13, vi. 3, 4, xii. 1). Accordingly, harmonies have been made comprising the three years' ministry, stating the events which in all probability happened in each of these years. ${ }^{1}$ This is a difficult task, as the only incident in John's Gospel which comes in contact with the ministry of our Lord, as recorded by the Synopties, is the feeding of the five thousand (John vi. 1-13), until we come to the narrative of the Passion. Most of this arrangement must, of course, be conjectural.

It is mmecessary to give a table of the harmony of the Gospels, as this has been so frequently done by others. If, as is most probable, Mark is the original Gospel, and was consulted by Matthew and Luke, then it is best to use the Gospel of Mark as the basis, and to draw up the harmony with the order there laid down. In this manner it is not difficult to group all the events recorded in the three Gospels (the triple narrative). We can then fill up the outline with the incidents recorded separately by Matthew, Mark, and Luke. It is probable that the great insertion in Luke's Gospel (Luke ix. 51-xviii. 14) is correctly termed the Peræan Gospel, and that the incidents therein recorded occurred in Peræa during our Lord's residence in that district, as stated by John, toward the close of His ministry (John x. 40). Christ.

1 See especially Caspari's Chronological Introduction to the Life of 


\section{THE GOSPEL OF MATTHEW.}

Literature.-The Gospel of Mathew has been often commented on. Omitting those commentaries included in the general commentaries of the New Testament, and those already indicated in the Literature of the Synoptic Gospels, the principal commentaries are those of Alexander of Princeton College (New York, 1861); De Wette (4th ed. Leipzig, 1857); Fwald, Die drei ersten Evangelien übersetzt und erklart (Göttingen, 1850); Lange (Bielefeld, 1861 ; English translation by Schaff, New York, 1864); Morison (London, 1870 ; last ed. 1883); Meyer (6th ed. 1876 ; Sth ed. by Weiss, 1890 ; English translation by the Rev. P. Christie, Edinburgh, 1877); Keil (Leipzig, 1877); Mansel in Speaker's Commentary (London, 1878); Plumptre (London, 1878); Kiibel (Munich, 1889); Carr in Cambridge Bible for Schools (London, 1890). Also Tholuck's Commentury on the Sermon on the Hount (Hamburg, 183:3 English translation, Elinburgh, 1860); Ebrard's Gospel History (translation, Edinburgh, 1860); Lord Arthur Hervey's Gencalogies of Our Lorel (Canbridge, 1883); liobert's Disenssions on the Crospels (Lonrlon, $1862)$; and Nicholson's Gospel aceording to the Hebrews (Loniton, 1879).

\section{I. (iRNUINENESS OF THE Gospel.}

We have alrealy consilered the gemnineness of the symoptic Gospels conjointly; but we repuire to consider the testimonies which relate to each Gospel separately; and this is especially necessary with regand to the Gospel of Matthew, on aceount of the peculiar nature of the evidence referring to it. 
Some critics have gone the length of asserting that the Gospel of Matthew has scriptural attestation in its favour, being quoted or referred to in the Epistle of James. ${ }^{1}$ The similarities between that Epistle and the Sermon on the Mount are indeed so numerous and striking that they cannot escape notice. ${ }^{2}$ Out of numerous instanees may be adduced three, in which the resemblances are most remarkable. "Howbeit if ye fulfil the royal law according to the Scripture, thou shalt love thy neighbour as thyself, ye do well "(Jas. ii. 8). These words, found in Matthew's Gospel (xxii. 39), appear to be given as an express quotation from Scripture

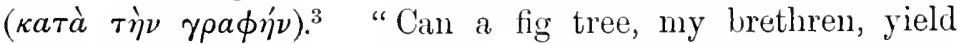
olives? or a vine, figs?" (Jas. iii. 12), where there is a strong similarity to our Lord's words in the Sermon on the Mount (Matt. vii. 16). "But above all things, my brethren, swear not; neither by the heaven nor by the earth, nor by any other oath: but let your yea be yea; and your nay, nay" (Jas. v. 12). This prohibition against swearing appears to be a direct citation from the Sermon on the Mount, where the same prohibition is given in almost identical terms (Matt. v. 34-37). We do not, however, think that these and similar expressions in the Epistle of James are references to or citations from Matthew's Gospel. The probability is that the Epistle was written before the Gospel. These similarities may be accounted for by referring them to the sayings of Christ, which, either in a written or in an oral form, were current among the early Christians, and which, as we have seen, formed one of the main sources of the Synoptic Gospels.

The most important docmment bearing upon the genuineness of the Gospel of Matthew is the Didaché, or "Teaching of the twelve apostles." This valuable document was discovered by Philotheos Bryennios in the Jerusalem monastery in Constantinople in 1873, and published by him in 1883.4

1 See Schnid, Biblical Theology of the N.T. Y]. 364-366.

2 Lists of these similarities are given by Theile, Kern, Huther, Schmid, Beyschlag, Reuss, Erdmann, Alford, Davidson, Bassett, Plumptre, and Salmon.

${ }^{3}$ James may be here quoting from the law of Moses, Lev. xix. 18.

"The reader is referred to Schaff's Oldest Church Manual for an 
There can be no reasonable doubt of its genuineness. It was repeatedly mentioned by the early Fathers. Clemens Alexandrinus quotes it as Scripture, ${ }^{1}$ and it is referred to by Irencens. Eusebius mentions it among the spurions writings. ${ }^{2}$ It appears to have been an early Church manual, possibly for the use and instruction of eatechumens, describing the "two ways," the way of life and the way of death. It has all the marks of high antiquity, as there are in it no references to the Gnostic heresies, nor to those changes in Church orders which arose in the beginning of the second century. " "The Didaché," observes Dr. Sehaff, "has the marks of the highest antiquity, and is one of the oldest, if not the very oldest, of post-ilpostolic writings. There is nothing in it whieh conld not have been written between A.D. 70 and 100." 4 It abounds with reminiscences of the words of Christ as given in Matthew's Gospel. There are at least twenty-two references, and several of them almost exact quotations. The following are the most striking references: "If anyone give thee a blow on the right cheek, turn to him the other also, and thou shalt be perfect. If anyone shall compel thee to go with him one mile, go with him twain. If anyone take away thy eloak, give him thy coat also." ${ }^{5}$ "Baptize ye into the name of the Father and of the Son and of the Holy Ghost,

exhamstive account of the Didaché; see also Tearhing of the Twelve Apostles, edited, with a translition and notes, by Boswell D. Hitchcock and liancis Brown, New York, 1884.

${ }^{1}$ Clemens Alexandrinus, Strom. i. 20 : "It is such a one that is called in Scripture (ypa甲ns) a thief. It is therefore said: "Son, le not a liar; for lying leads to theft." Comp. Didaché iii. 5: "My child, become not a liar ; since lying lends to theft."

"Euseline, Ilist. Eed. iii. 25. All that Eusebins probally means is that it was not written by the apostles. It is included in the strichometry of Niceplontus.

"It is a matter of dispute whether the description of "the two ways"

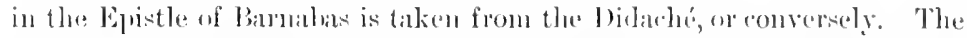
priority of the Bidache is adrocated ly Zahn, Funk, and langene, and denied hy Bryemios, Hilgonfede, and Hamack; whilst Bishop Light foot and Warfiedd sulpesed that hoth Barmabas and the writer of the Didaché drew liom an common solure which is lost.

"Schafl's (Mlest Churh Mannal, 1. 119.

"Ch. i. 4 ; comp. Matt. v. 39-41. 
in living water." 1 "Neither pray ye as the hypocrites, but as the Lord commanded in His gospel. After this manner pray ye"; and then follows the Lord's Prayer, including the doxology." "The Lord hath said, Give not that whieh is holy unto dogs." 3 Now, the question is, How are we to aecount for these minute resemblances? If the citations had been eonfined to passages contained in the Sermon on the Mount, we might suppose that, as in the ease of the Epistle of James, they may have been taken from the oral Gospel as preached by the apostles. ${ }^{4}$ But as they extend to other parts of Matthew's Gospel, we appear to be shut up to the conclusion that they are actual quotations from that Gospel: that the author or authors of the Didaché, in drawing up this Church manual, drew many of the precepts contained in it from the first Gospel. The parallels are much closer than those found in the writings of the apostolic Fathers or of Justin Martyr. ${ }^{5}$

The Gospel of Matthew is referred to or quoted by all the apostolic Fathers. Thus Clemens Romanus (A.D. 96) says : "Remember the words of the Lord Jesus which He spoke concerning gentleness and longsuffering. For thus $\mathrm{He}$ said, Be ye merciful, that ye may obtain mercy. Forgive, that it may be forgiven you: as ye do, so shall it be done unto you; as ye judge, so shall ye be judged; as ye are kind, so shall kindness be shown to you; with what measure ye mete, it shall be measured to you." 6 And again: "Remember the words of the Lord Jesus Christ, how He said, Woe to that man; it would be better for him that he had never been born, than that he should offend one of My elect. It were better for him that a millstone should be hung about his neck, and that he should be drowned in the sea, than that he should offend one of My little ones." 7

1 Ch. vii. 1 ; comp. Matt. xxviii. 19.

2 Ch. viii. 2 ; comp. Matt. vi. $5,9-13$.

${ }^{3}$ Ch. ix. 5 ; comp. Matt. vii. 6.

4 The opinion of Lechler.

${ }^{5}$ It is, however, to be observed that Dr. Salmon supposes that the Didaché of Bryemnios had been preceded by a shorter form which did not contain the references to the Sermon on the Mount; Introduction to the N.T. 7 th ed. p. 559.

${ }^{6}$ Clemens Romanus, ch. xiii. ; comp. Matt. vi. 12-15, vii. 2.

7 Ibil. xlvi.; comp. Matt. xviii. 6. 
One of the earliest of the Christian writings is the socalled Epistle of Barnabas. The whole Greek text of this Epistle is found in the Sinaitie manuscript ( ), not, however, as if it were one of the eanonical books of the New Testament, but as an extra-eanonical book, being placed after the Apoealypse. Another mannseript of this Epistle was one of the improtant discoveries of Bryennios. ${ }^{1}$ It is of doubtful origin. Clemens Alexandrinus repeatedly quotes it, and expressly attributes it to the Apostle Barnaluas, the companion of Paul. ${ }^{2}$ Elsewhere he states that he was one of the Seventy. Origen quotes it twice, and ealls it the Ejpistle of Barnabas. ${ }^{3}$ Jerome also assigns the authorship of the Epistle to Barnabas. ${ }^{4}$ Ensebius, on the other hand, ranks it among the spurions books. ${ }^{5}$ In the present day it is generally regarded by biblieal seholars as not the work of Barnabas. ${ }^{6}$ But whether genuine or not, its great antiquity is miversally admitted. Such high authorities as Bishop' Lightfoot ${ }^{7}$ and Weizsäcker, arguing from a passage found in it giving an enumeration of the Roman emperors, infer that it was written in the reign of Vespasian, shortly after the destruetion of Jerusalem ${ }^{8}$ (A.D. 70). But the inference

${ }^{1}$ In the sime volnme which contained the Didaché. The documents: contained in that volume are as follows:-1. A Synopsis of the Old and New Testaments by Chrysustom; 2. The Epistle of Barnabas; 3. The First Epistle of Clement; 4. The Second Elpistle of Clement ; 5. The Didaché; 6. The Spurious Epistle of Mary of Cassolboli; 7. Tweelve Pseudo-Ignatian Ejistles.

${ }^{2}$ Clemens Alexandrims, Strom. ii. 6.

3 Origen, De Principioss, iii. 2 ; Contre Celsum, i. 63.

${ }^{4}$ Jerome, De Vir. Ill. $6 . \quad{ }^{5}$ Ensebins, Hist. Erel. iii. 25.

${ }^{6}$ Its genuineness has been defended by Professor Milligan, smith's Christicu Biography, article "Barmabas." Its genuineness in also maintained by (rieseler, Gnericke, Bleck.

'Lightfont's A postolir Futhers: St. Clement of Rome, wol. ii. 1. jolo. With lightfort and Weizaicker, Professor Sanday also agrees. Ster Sandiay's Bumptom Lectures, P. 235, and also Dr. Sillmon's Introduction to the N.T. Tth etl. 1. 518 .

"The gassage is ats follows:- "Ten kingdoms shall reign upon the earth, and a little king shall rise up after them, who shall suldue three of the kings muler one. In like mamer Diniel says concerning the sane: And I saw the fourth heast, wieked and strong and salvage beyond all the bensts of the carth, and low from it sprang "up ten loorns, and ont of 
which they draw from this passage is doubtful. The most generally received opinion is that the Epistle of Barnabas was written by an unknown author toward the close of the first century (A.D. 100). The following quotations from Matthew's Gospel are found in it: "Let us beware, lest we

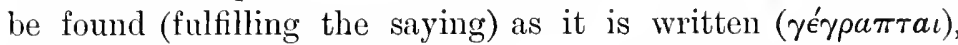
Many are called, but few chosen." 1 "But when He chose His apostles who were to preach the gospel, He did so from among those who were sinners above others, that He might show that He came not to call the righteous, but simmers to repentance." 2

The next Father, in order of date, is Ignatius (A.D. 118). The genuineness of his Epistles has long been the subject of dispute. They exist in two recensions, the larger and smaller or Vossian recension. Cureton discovered a Syriac manuscript containing only three Epistles, and these in a more abridged form than the smaller recension. After the learned investigations of Bishop Lightfoot, it is now generally acknowledged that the seven Epistles found in the smaller recension are genuine, though perhaps containing several interpolations, and that the Curetonian recension is an abridgment. ${ }^{3}$ Now, in the Epistle of Ignatius to the Romans, the best attested of all his Epistles, we have the following distinct quotation from Matthew: "It is better to die for the sake of Jesus Christ than to reign over all the ends of the earth: for what shall a man be profited if he gain the whole world, but lose his own soul." 4 And in the Epistle to Polycarp we have the following words: "Mitigate violent attacks by gentle applications. Be in all things wise as a serpent and harmless as a dove." 5 them a little horn, an offshoot, and how it snbdued under one three of the great horns," Barnabas, ch. iv. According to Lightfoot, the three great horns are Vespasian, Titus, and Domitian, who ruled conjointly; and the little horn who was to subdue them was Nero revived. See also Ramsay's The Church in the Roman Empire, p. 307.

1 Barnabas, ch. iv.; comp. Matt. xx. 16.

2 Barnabas, ch. v.; comp. Matt. ix. 13.

3 The reader is referred to Bishop Lightfoot's learned and exhaustive work, Apostolic Futhers: St. Ignatius and St. Polycarp. See also Zahn's Ignatius von Antioch; Gloag's Introduction to the Johannine Writings, lp. $100 \mathrm{f}$.

${ }^{4}$ Ep. ad Romanos, ch. vi.; comp. Matt. xvi. 26.

5 Ep. ad Polycarp, ch. ii.; comp. Matt. x. 16. The words here are 
The Epistle of Polycarp (A.D. 116) was written shortly after the martyrdom of Ignatius. Its genuineness is attested by Irenceus, who was one of his diseiples: "There is also a powerful Epistle of Polyearp written to the Philippians, from whieh those who ehoose to do so, and are anxions about their salvation, can learn the eharacter of his faith and the preaching of his truth." 1 In this Epistle of Iolycarp there are two quotations from the Gospel of Matthew. "Iiemember what the Lord said in His teaching, Judge not, that ye be not judged: forgive, and it shall be forgiven unto you: be merciful, that you may obtain merey. With what measure ye mete, it shall be measured to you again. And once more, Blessed are the poor and those that are persecuted for righteousness' sake: for theirs is the kingdom of God." 2 "Beseeching the all-seeing God in our supplications not to lead us into temptation; for as the Lord has said, The spirit truly is willing, but the flesh is weak." 3

We have already had frequent occasion to allude to the testimony of Papias (A.D. 120). "So then Matthew wrote

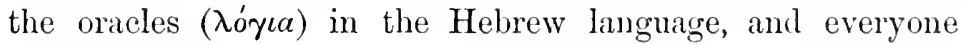
interpreted them as he was able." ${ }^{4}$ We have endeavoured to show that Papias here does not, as many biblical scholars affirm, speak of some original document which lay at the foundation of Matthew's Gospel - the nuelens of that Gospel; but that he alludes to the canonical Gospel as we possess it, and which was in existence in his days. ${ }^{5}$

It is unneeessary to refer to the testimony of the early post-apostolie Fathers; for it is now hardly disputed that the Gospel of Matthew was received as anthentic by the Christian Church in the middle of the seeond century. Justin Martyr (A.D. 150), when he speaks of the Memoirs or Memorabilia of Christ, frequently refers to this (rospel, without, however, naming it, often quoting the precise worls, but

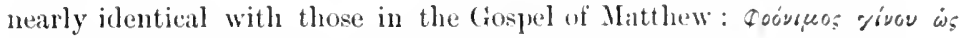

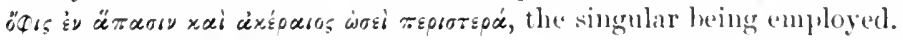

${ }^{1}$ Irenceus, $A d v$. Horr. iii. 3. 4.

2 Polycar], Ep. ad Philip. ch. ii.; comp. Matt. vii. 1, 2, v. :3, 10.

${ }^{3}$ Ilid. ch. vii.; comp. Matt. vi. 13, xxvi. 41.

4 Eusebius, Mist. Edel. iii. $40 . \quad$ "Sumer, l'l. 18-20. 
more frequently quoting from memory, thus occasioning a slight difference between the words of Jesus as quoted by Justin and those found in the Gospels. It is unnecessary to give instances of the quotations which are scattered throughout all the writings of Justin. Jeremiah Jones gives twenty-seven quotations from the Gospel of Matthew by Justin, ${ }^{1}$ whilst Kirchhofer increases the number to thirtyone. ${ }^{2}$ Professor Sanday gives us a table of all the references of Justin to our Gospels, and observes: "The total result may be taken to be that ten passages are substantially exact, while twenty-five present slight, and thirty-six marked variations." 3

Irenæus (A.D. 180) is the first Father who names Matthew as the author of the first Gospel. "Matthew, the apostle, declares that John, when preparing the way for Christ, said to those who were boasting of their relationship to Abraham: $O$ generation of vipers, who hath shown you to flee from the wrath to come? Bring forth therefore fruit meet for repentince." 4 And again: "Matthew, when speaking of the angel, says: The angel of the Lord appeared to Joseph in sleep." 5

But the genuineness of Matthew's Gospel is not only attested by the early Fathers, but also by the early Gnostic heretics. Basilides (A.D. 125), Valentimus (A.D. 150), ${ }^{6}$ and Heracleon (A.D. 160), in the fragments of their works preserved in the writings of the Fathers, have references to or citations from it. ${ }^{7}$ Besides, there are the Old Latin and Syriac versions made about the middle, or at least before the close of the second century. It is more than probable that the Gospels were the first books which were received by the Christian Church as canonical and divinely inspired, and were read, as Justin informs us, in their public assemblies. This would naturally be the case, as the life of Christ, His discourses and actions, would be regarded by the early Chris-

${ }^{1}$ Jones, On the Canon, vol. iii. p. 27.

2 Kirchhofer's Quellensammlung, pp. 89-104.

${ }^{3}$ Sanday's Gospels of the Second Century, 1p. 113-116.

${ }^{4}$ Irenæus, $A d v . H(e r$. iii. 9.1 ; conly. Matt. iii. 7.

"Ibid. iii. 9. 2 ; comp. Matt. i. 20, 21.

"Ibid. i. 8. 2.

7 See Davidson's Introduction to the N.T. 1st ed, vol. i. pp. 70, 71. Sanday's Gospels of the Second Century, pr. $188 \mathrm{ff}$. 
tians of primary importance. This consideration sufficiently aceounts for references to them being of such early date.

Although, certainly, the gemmineness of Matthew's Gospel rests chiefly on the external evidence, which is in itself perfectly sufficient, yet there is not wanting internal evidence which eonfirms the extermal, thongh we do not place the stress of the argument on it. The attributing of the Gospel to Matthew, a eomparatively nnknown and obseure apostle, is in itself a presumption in its favour. If the design were to palm a Gospel upon the Church, it would not be attributed to an apostle who is never mentioned, except in the nurrative of his call and in the lists of the apostles, and of whom there are hardly any records in ecclesiastical history; but to some more distinguished apostle, such as Peter, James, Andrew, Thomas, or Philip, whose names oceur in the Gospels in connection with events in the life of Jesus. Besides, this Gospel contains within itself the evidences of its anthenticity; it hears upon it the impress of truth. The discourses of our Lord, especially the parables and the Sermon on the Momt as there recorled, are beyond the capacity of the human intellect to compose; they are divine utterances, and all attempts to imitate them end in failure. Even those inspired writings which follow the Gospels are cast in a different mould; they want the simplicity, the freshess, the naturalness, the impressiveness of the parabolic element. As Professor Salmon says: "In point of style we travel into a new comntry, when we pass from the Synoptic Gospels to the Apostolie Epistles "; ${ }^{1}$ whilst the writings of the apostolie Finthers are mere dross compared with the grold fomm in the Gospels.

But, notwithstanding this strong attestation in furour of the (xospel of Matthew, its gennineness has been dispruted on varions gromuls. The doubts as to its apostolic origin are dlawn from the nature of the work, and not from any lefeet in the external evidenee. They arise chiefly from the exirencies of the ease in the attempts of crities to solve the syonoptic problen. It has in reeent times been clisputed by 1 Sallnem's Introduction to the N.T'. 1. 136. 
Schleiermacher, Sieffert, ${ }^{1}$ Eichhorn, ${ }^{2}$ Meyer, Reuss, Holtzmann, De Wette, ${ }^{3}$ and Davidson.

1. It is affirmed that the Gospel, as we now have it, cannot be the original Gospel of Matthew, but must be a compilation; that there was a previous Aramaic Gospel, or a collection of Logia, probably written by Matthew, which formed the groundwork or nucleus of the canonical Gospel; that this Aramaic Gospel was increased by subsequent additions at different periods, and was translated by different persons, and that from this our canonical Gospel was gradually formed; that the original Gospel is now lost, and that what we now have is a translation or recension of it with additions by au unknown author or authors. This is the opinion of those who hold the two document hypothesis. Thus Meyer observes: "In the form in which the Gospel now exists, it cannot have originally proceeded from the hands of the Apostle Matthew." 4 Professor Sanday, in his article in the Expositor, already referred to, says: "This at least is a point on which there is increasing unanimity, that the Apostle Matthew did not write the whole of the first Gospel as we have it. That he wrote a section of it, so important that his name passed from that to the whole, is by most writers willingly conceded; but analysis reveals the composite nature of our Gospel too clearly for it to be probable that we have in it the original work of our apostle, as it left his pen." 5 And so also Dr. Marcus Dods observes: "In the present state of criticism, it is impossible to speak with certainty of the origin of the first Gospel. That the apostle, by whose name it is still called, had something to do with its composition is tolerably certain, but it is also certain that it passed through more hands than his before it reached its present form." 6

Now it is admitted that in a certain sense the Gospel of

1 Ueber den Ursprung des ersten Kanonischen Evangeliums.

2 According to his theory of the original Gospel, which regards the canonical Gospel as a later edition. So also all those who adopt his theory or the modern modification of it.

"See De Wette's Einleitung, $\S 98$.

4 Meyer, Matthew, vol. i. p. 3, translation.

5 The Expositor, vol. iii. fourth series, p. 303.

- The Supernatural in Christianity; p. 83. 
Matthew may be regarded as a compilation. How far it is so will be more fully determined when we come to consider the sources of the Gospel. But it is not a compilation in the sense of those objectors, namely, that there is only a nucleus which can primarily be referred to Matthew, whilst the rest has arisen from subsequent additions or aceretions. A change of Gospels, the substitution of one for another, or the enlargement of a previons Gospel, is not only never hinted at by the Fathers, but its occurrence is difficult to conceive, considering the sacredness attached to these records of the life of Jesus; it would involve time, and the early formation of Matthew's Gospel does not give sufficient time for such a growth and development. This Gospel was certainly recognised before the close of the first century, and time must be allowed even for this early recognition. Besides, the uniformity of style and expression in our Gospel proves the unity of authorship. There are the same expressions, as, for example, "That it might be fulfilled," "the kingdom of heaven," " "the end of the world," continually recurring, and marking the individuality of the author. ${ }^{2}$

2. It has been maintained that the first Gospel, at least as we now have it, could not possibly be the work of an apostle who was the constant follower of our Lord, because it wants all the characteristics of an eye-witness. Many of the most important incidents of our Lord's life are omitted. There is no mention of the Judæan ministry which, as we learn from the Gospel of John, formed so important a part of our Lord's mission. In the marrative there is a complete want of graphic description; it is a narrative of incidents without anything to suggest that the narrator himself was present when these incidents occurred.

To this objection it is replied that it was not the design of Matthew or of any of the evangelists to compose a complete biography of Christ, but merely to give a sufficient

1 Whilst elsewhere in Scripture the plurase is the kingdom of God,

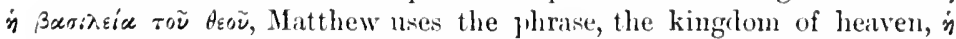

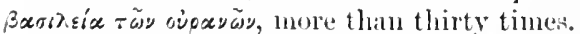

${ }^{2} \Lambda$ full list of these preculiarities in Matthew's Gospel is given hy Credner, Einleitung in des N.T. p. 63. 
selection of facts from a life so full and beneficent. The Judiean ministry is omitted probably because that ministry occupied so small a portion of the life of Christ; it was only occasionally, at the annual festivals, that $\mathrm{He}$ went up to Jerusalem; by far the greater portion of His life was spent in Galilee. Besides, there are indications in this Gospel that our Lord, during the course of His public ministry, did visit Judrea. Thus we read: "It came to pass, when Jesus had fimished these words, He departed from (xalilee, and came into the borders of Judiea beyond Jordan" (Matt. xix. 1). And with regard to the want of graphic details, this has been greatly exaggerated, althongh it is admitted that in this particular the Gospel of Matthew is surpassed by the Gospel of Mark. This, however, is no objection to the genuineness of the Gospel. To write in a graphic manner depends upon the idiosyncrasy of the writer $;^{1}$ and, as has been well remarked: "This is a phenomenon which meets us every day; it is not the contemporary and the eye-witness, but the historian of a succeeding age who takes the keenest interest in minute detail, and records with faithful accuracy the less prominent circumstances of a great event." 2

3. The want of chronological order is frequently adduced as an argument against the genuineness of Matthew's Gospel. We have already had occasion to advert to the chronological order of the evangelists. ${ }^{3}$ It is seldom that the three evangelists are at variance on this point. The most obvious case is the stilling of the storm and the cure of the Gadarene demoniac recorded by all three. ${ }^{4}$ In Matthew these incidents are stated as having occurred before our Lord had

1 "It is," observes Dr. Davirkon, "a weak argument to adduce the want of graphic deseription in one who was an eye-witness like Matthew. The power of vivid description is a talent which does not depent on an external call. ... If the writer had not the gift of picturesqueness before he became an apostle, he did not get it afterwards." Introduction to N.T. 3rd ed. vol. i. p. 343.

2 Carr's Gospel of Matthex, p. 11. He illustrates this by Macaulay's graphic description of the reign of James II.

$\checkmark$ See supra, p. 41.

${ }^{4}$ Matt. viii. 23 ; Mark iv. 35 ; Luke viii. 22. See Norton, Genuineness of the Gospels, vol. i. 1'1. 293, 294. 
delivered the parable of the Sower and the other kindred parables; whilst Mark and Luke reverse the order, and inform us that it was after our Lord had delivered these parables on "that day when the even was come that $\mathrm{He}$ said unto them, Let us go over unto the other side" (Mark iv. 35) I3ut we cannot see how this is any objection against the genuineness of the Gospel; the difference is very slight and unimportant. The evangelists do not scek to follow a chronological order in their narrative; there are undoubtedly variations on this point between them. The orler laid down in the Gospel of Mark is in general the order to which Mathew and Luke adhere; but it is donbtful if even this order is correct. Exact chronology was a mere secondary consideration with the evangelists.

4. It has further been objected that there are mythical incidents recorded in the Gospel of Matthew which render his whole narrative suspicious. The incidents alluded to are those which are stated to have occurred at the death of Christ-the rending of the vail of the temple, the earthquake, and the saints coming forth from their tombs (Matt. xxvii. 51-53). The rending of the vail of the temple is mentioned by the other two evangelists, so that it is to the resurrection of the saints, which is recorded by Matthew only, that the objection applies. Many admit the legendary nature of this incident, and suppose that it was not an original part of Matthew's Gospel, but an insertion by a later hand. Thus Meycr calls it "a mythical apocryphal addition," and supposes that the Greek editor of Matthew inserted it in translating from the Hebrew Matthew. ${ }^{1}$ Similarly Norton observes: "The story must be regarded as a fable, probably one which, in common with others now utterly forgotten, was in circulation among the Hebrew converts after the destruction of Jerusalem. Some possessor of a mannseript of Matthew's Hebrew Crospel may he supposed to have noted it in the margin of his copy, whence it foumd its way into the text of others, one or more of which fell into the hands of the Greek transhator." ' There is, however, no critical ground to justify

1 Meyer, in loco.

1 Norton's Genuineness of the Cospels, vol. i. pp. 214, 215. 
this supposition. The incident is omitted in no Greek manuscript. It is adverted to by Ignatius when, speaking of our Lord's descent into Hades, he says: "He whom they rightly waited for being come, raised them from the dead." 1 Others suppose that the passage is not to be understood literally, but symbolically, as an emblem of Christ's victory over death and the grave; but for this supposition there is no ground: it is recorded as part of a narrative. It is one of those supermatural incidents which meet us in every page of the Gospels. It is true that this wonderful and miraculous incident is only recorded by Matthew; but there are other supermatural events, equally wonderful, which are recorded in only one of the Gospels: as the raising of the son of the widow of Nain by Luke, and of Lazarus by John.

5. Another objection to the genuineness of the Gospel according to Matthew is, that there are in it frequent repetitions of the same events, showing that the author of the Gospel incorporated without revision two documents, each of which gave a narrative of the same incident. Thus Dr. Davidson olserves: "Other particulars are wrongly narrated, as is the case with the miraculons feeding of the four thousand men in the wilderness very soon after a similar event (comp. xv. 32-38 with xiv. 16-21). In like manner, the same transaction is repeated in xii. $22-30$ and ix. $32-34$, which passages are so similar that we must assume a double narrative of the same event. A similar repetition of the same thing appears in xvi. 1, where the event in xii. 38 is re-enacted. The number of these duplicates is considerable, so much so as to show carelessness, forgetfulness, or needless accumulation of material." 2

We have already alluded to this subject when we considered the existence of doublets in the Synoptic Gospels, and need not repeat what was then said. ${ }^{3}$ In the instances stated by Dr. Davidson there is a similarity, but not an identity of particulars. The two accounts of the miraculous feeding of

${ }^{1}$ Ignatius, Ep. ad Magnes. ch. ix. It is also referred to in the apocryphal Gospel of Nicodemus. Jones, On the Canon, vol. ii. 1. 255.

2 Davidson's Intraduction to the N.T. vol. i. pp. 339, 340, 3rd ed.

${ }^{3}$ See supra, p. 37. 
the multitude differ in many points, in the amount of provisions, in the number fed, and in the quantity of fragments afterwards gathered; in the two miraculous cures, in the one case the man possessed with a devil was blind and dumb, in the other case he was only dumb but not blind; and the demand of the Pharisees for a sign from heaven might have been twice repeated, as such signs were regarded by them as the credentials of the Messiah.

\section{Tile Author of the Gospel.}

Irenæus is the first Father who assigns our first Gospel to Matthew. We have an account of his call to the apostleship given us by all the Synoptists. ${ }^{1}$ The name Matthew in Hebrew (מַתחת signifies the gift of Jehorah, similar to the Greek $\Theta \epsilon o \delta \omega p o s$. In the list of the apostles given by Mark he is called "the son of Alphrus" (Mark ii. 14), and as another apostle is called "James the son of Alphaus" (Luke vi. 15), it is inferred that these apostles were brothers. Others, inferring from various indications in Scripture that Alphxus is the same as Clopas the husband of Mary, the sister of the Virgin, ${ }^{2}$ suppose that Matthew was nearly related to our Lord. And other's from his frequent conjunction with Thomas, called Jidymus or "the twin," that he was his brother. All these are ille conjectures. Matthew was by occupation a publican or tax-gatherer, a member of a class hated and despised by the Jews, as collectors of a hateful tax and standing memorials of their subjoction to the Romans. Hence the phrase "publicans and sinners." As, however, Capernam was in the province of Calilee, the dominion of Herod Antipas, it is not improbable that Matthew was an officer under that monarch, and not under the Romans. The promptitude with which he obeyel the call of Christ is an indication that there had been a previons preparation going on within him, and that he had been impressed with the teach-

1 Matt. ix. 9-13; Mark ii. 14-17; Luke r. 27-3:2.

2 The Apreste. Tames the Less is mentioned at the som of Alphens (Mark iii. 18) and as the son of Mary (Mark xr. 401), supposed to be the same at Mary the wife of (thophat or Clopas (John xix. 25). 
ing of Jesus. Matthew made a great feast in honour of Christ, at which many publicans and sinners sat down with Jesus and His disciples.

In the account given by Mark and Luke, Levi appears as the name of the publican who was called; ${ }^{1}$ whilst in the lists of the apostles given by the same evangelists the name is Matthew, without any notification that he is the same as Levi formerly mentioned. ${ }^{2}$ Hence it has not unreasonably been inferred that we have the account of the call of two different persons, of Matthew who afterwards became an apostle, and of Levi who was only a disciple. Some suppose that Levi was a superintendent publican and that Matthew was his subordinate, and that our Lord ealled both at the same time. This distinction between Matthew and Levi was recognised by the Fathers. Clemens Alexandrinus, quoting from Heracleon the Gnostic, mentions Matthew, Philip, Thomas, Levi and many others who did not suffer martyrdom, but died a natural death. ${ }^{3}$ So also Origen in his answer to Celsus, who taunts the Christians with the low condition of the apostles, inasmuch as they were publicans and fishermen, observes that Matthew and Levi, or as he calls him Lebes (o $\Lambda \epsilon \beta \hat{\eta} s$ ), were publicans. ${ }^{+}$The same opinion was held by Grotins, Michaelis, Neander, Sieffert, Hase, Hilgenfeld, and Reuss. ${ }^{5}$ As, however, the incidents are recorded by the three erangelists in almost precisely the same words, it is highly probable that their narratives relate to the same event; and consequently that the Levi of Mark and Luke is the same as the Matthew of Matthew's Gospel. The use of two names was not uncommon among the Jews at this time; for example, Simon was called Peter, Lebbæus was surnamed Thaddeus, Thomas was called Didymus, Joses was called Barnabas, John was surnamed Mark, Simon was called Niger, Judas was surnamed Barsabas, and Saul was also called Paul.

1 Mark ii. 14 ; Luke v. 27.

2 Mark iii. 16 ; Luke vi. 15.

${ }^{2}$ Clemens Alex. Strom. iv. 9.

${ }^{4}$ Origen, Contra Celsum, i. 62. It is, however, possible that ly Lebes, Origen might intend the Apostle Lebheus, Matt. x. 3.

${ }^{5}$ De Wette's Einleituny in dus N.T. $s 97 u$. 
We have hardly any notices of Matthew in the patristic writings and in ecclesiastical history, and what we have are of a legendary nature. Clemens Alexandrinus tells us that he led an ascetic life: "The Apostle Matthew partook of seeds and nuts and vegetables without flesh " $;{ }^{1}$ and he has preserved the following saying of Matthew recorded in some Gnostic writing: "They (the Gnostics) say in the traditions that Matthew the apostle constantly said, "If the neighbour of an elect man sin, the elect man has sinned. For had he conducted himself as the Word prescribes, his neighbour also would have been filled with such reverence for the life he led as not to sin." "2 Eusebius informs us that Matthew, after he had preached the gospel to the Hebrews, that is, to the Jews in Palestine, went forth to other lands, but withont mentioning any particular country. ${ }^{3}$ Socrates, in his Church history, says that he went to Ethiopia. ${ }^{4}$ Other writers mention Parthia, India, and Macedonia. Some affirm that he died a natural death, whilst Nicephorus states that he suffered martyrdom in Ethiopia. ${ }^{5}$

\section{The Sources of the Gospel.}

It is a very difficult question to answer, Whence did Matthew obtain the materials out of which he formed his Gospel? We may distinguish three sources: 1. Personal observation. If the anthor of this Gospel was the Apostle Matthew, he would be one of the constant followers of Christ, a witness of many of His actions, and a listener to many of His discourses. He would also come into intimate contact with his fellow-apostles, and thus from their narratives would supplement his own. Matthew then would not be merely a compiler of the sayings or writings of others, but a narrator of what he himself saw and heard. 2. Orul tradition. This must have been the source of muel of the Synoptic narratives. As we have already seen reason to

Clemens Alex. P'mlay. ii. 1.

2 Clemens Alex. Strom. vii, 13.

${ }^{3}$ Eusel lius, Hist. Ererl. iii. 24.

4 Socrates, Hist. Ecel. i. 19.

5 The Catholic Chureh keeps september 21 st as the anniversary of his martyrdom. See Cave's Live's of the A postles. 
believe, that before anything was reduced to writing there was a certain stereotyped form of an oral Gospel which constituted the teaching of the apostles for the use of catechumens. 3. Written documents. We have stated that it is probable that at a very early period there were Gospel fragments. To the use of these written documents we attribute the great similarity that exists in many portions of the Synoptic Gospels. There was a historical framework common to all three. The account of the birth of our Lord, the visit of the Magi and the flight into Egypt, in the first two chapter's of this Gospel, was probably an early document derived from Mary or from the brethren of our Lord, and treasured up by the primitive Church. The discourses and parables of our Lord were perhaps collections made of the sayings of Christ which would be distributed throughout the churches. We have also seen that it is extremely probable that Matthew made a free use of the previously written Gospel of Mark.

According to Papias, Matthew composed his oracles ( $\lambda$ órıa) in the Hebrew language. We have already seen that the term $\lambda$ ó $ı$ a is not to be restricted to the discourses of Jesus, but includes also the incidents of His life, in short, that it is equivalent to Gospel. It is, however, undoubtedly true that this Gospel, more than the other two, contains long discourses of our Lord, and in this particular resembles the Gospel of John; whether these discourses were delivered in full at one time, or whether they are collections of the sayings of Jesus delivered at different times. Examples of these are the Sermon on the Mount (v.-vii.), the apostolic commission (x.), the testimony concerning the Baptist (xi.), the series of early parables (xiii.), the characteristics of discipleship (xviii.), a second series of parables (xxi. 2Sxxii. 14), disputes with the Pharisees and Sadducees (xxii. 15-40), the denumciation pronomced against the scribes and Pharisees (xxiii.), the prediction concerning the destruction of Jerusalem (xxiv.), and the so-called parables of the passion (xxv.). The designation $\lambda$ órıa, applied to the Gospel of Matthew, is highly appropriate. It is a plausible and attractive idea that these sayings or discourses of Jesus formed the original Gospel of Matthew, and that the other portions 
were subsequent additions made by unknown editors. ${ }^{1}$ Thus Weiss supposes that the discourses of Matthew formed the original Gospel, and were the groundwork of the three Synopties. But such an idea is extremely problematic and incapable of proof. As ahrealy stated, the same style and language, the same favourite expressions, pervade the whole (rospel, and prove the mity of anthorship. Matthew, it would appear, was a colleetor of the sayings of Jesus, and united in one discourse many utterances which were spoken at different times, and many parables which were delivered on different oceasions. In all probability these collections were made by Matthew himself of the sayings of Jesus, which were either handed down by tradition, or existed in written doeuments, or were heard by himself. Mathew drew them from Galilean tradition, whether oral or written, or from aetual knowledge.

\section{Tile Desigr of the Gospel.}

It is the uniform testimony of the Fathers that Matthew wrote his Gospel for the use and benefit of the Hebrew Christians; that is, not only for those who were resident in Palestine, but for Jewish eonverts scattered throughout the world. Thus Origen, as quoted by Eusebius, observes: "Among the four Gospels, which are the only indisputable ones in the Churehes of Goul, I have learnt by tradition that the first was written by Matthew, who was once a publiean, but afterwarls an apostle of Jesus Christ, and it was prepared for the converts from Judaism and published in the Hebrew language." Its chief design was evitently to prove that Jesus was the Christ; that the Messianie propheries of the old 'lestament received their accomplishment in Him. The

${ }^{1}$ View of cimlet, Now Tratement Stutles, P. 20: "Sime "omljutor of Matthew," he olserves, "who had helped him in his work wi "limgelisition, underton the lahome of translating into Greek the disemerses which latd heen dliwn up by him in their original language, amb to complete this work by distributing their contents through an evangelinal narrative, complete in itself and conformable to the type of ('hriatian instruetion arhited by the apostles."

"Eusehine, Mist. Errl. vi. 25. 
genealogy of Jesus is traced back, not as in Luke's Gospel to Adam, the ancestor of the human race, but to David the Messianic king, and to Abraham the father of the Jewish nation. The Gospel commences with the words: "The book of the generation of Jesus Christ the son of David, the son of Abraham." In the Sermon on the Mount, where the principles of the religion of Jesus are enunciated, our Lord says that "He came not to destroy the law and the prophets, but to fulfil them"; to impart to the commandments of the moral law a higher and more spiritual meaning. Jewish customs and localities are supposed to be known to the reader. Jerusalem is called the holy city, and Bethlehem the city of David. The teaching of Matthew's Gospel resembles that of the Epistle of James in regarding Christianity not as superseding Judaism, but as its development.

Hence the Gospel of Matthew, above all the other Gospels, is pervaded by the old Testament; there are more than seventy quotations from it, or references to it. This Gospel is interwoven with proofs of the Messiahship of Jesus. His birth is foretold under the Messianic name, Emmanuel (i. 23); He is born in Bethlehem of Judrea, becanse so it was foretold by the prophets (ii. 6); $\mathrm{He}$ and $\mathrm{His}$ parents fled to Egypt, "that what was spoken by the prophets might be fulfilled" (ii. 15); the massacre of the children of Bethlehem took place, in fulfilment of the words spoken by Jeremiah the prophet (ii. 18); He came and dwelt in Nazareth, "that it might be fulfilled what was spoken by the prophet" (ii. 23); John the Baptist was His forerunner, as was foretold by the prophet Esaias (iii. 3, xi. 10); leaving Nazareth, He came and dwelt in Capernaum, that the words of Esaias the prophet might be accomplished (iv. 13, 14); $\mathrm{He}$ cured diseases, that that which was spoken by Esaias might be fulfilled (viii. 17); He was possessed of a meek and retiring disposition, according to the description of His character given by the same prophet (xii. 17-21); $\mathrm{He}$ taught the multitude in parables, as was foretold of Him (xiii. 35, 36); He entered Jerusalem in lowly triumph riding upon an ass, in accordance with the prediction of Zechariah (xxi. 4,5); He appealed to the words of David, 
in proof of His Messiahship (xxii. 41-45); at His apprehension all His disciples forsook Him, in fulfilment of the prophet's statement (xxvi. 31); He was sold for thirty pieces of silver, the exact sum stated by the prophet (xxvii. 9); the soldiers who crucified Him parted His garments among them, and thus unconsciously fulfilled the statement of the prophet (xxvii. 35); and on the cross, in the hour of His agony, He appropriated to Himself the words of the prophetic I'salmist (xxvii. 46). The formula, "that it might be fulfilled" (ö $\pi \omega \varsigma \pi \lambda \eta \rho \omega \theta \hat{\eta})$, occurs eight times in this Gospel. ${ }^{1}$ The life of Jesus is recorded as the fulfilment of prophecy; He is portrayed as the great Messianic King, to whom all the prophets bear witness, and in whose life their predictions received their accomplishment. ${ }^{2}$

\section{The Language of the Gospel.}

The subject which we have now to discuss is one of extreme difficulty. In what language was the Gospel of Matthew written? Was it Hebrew, that is, Aramaic, ${ }^{3}$ or Greek? The difficulty consists in the conflict between the external and internal evidences: the former being in favour of an original Aramaic Gospel, and the latter tending to show that the Gospel of Matthew, as we now possess it, must have bcen written in Greek, and camnot be a translation. There is no difficulty in believing that some of the docnmentary sources of the Synoptic Gospels may have been written in Aramaic; but the question is, Was there an original Aramicic Gospel, of which the canonical Gospel of

1 Matt. i. 22, ii. 15, 23, viii. 17, xii. 17, xiii. 35, xxi. 4, xxvii. 35.

2 "Matthew desired to set forth Jesus to the Jews als their very" Christ; the Legislator of a new and spiritual law ; the King of a new and spiritual fominion; the Prophet of a new and miversal Chureh; the divine Messiah who should woon resolve all donbts, returning in the clouds of heaven to jurlge and silve." Farrar, The Wessetges of the liooks, p. 40.

"We frernently nse the term Helnew, beeause it is so nsed in Scripture and in the writings of the Fathers; lont the vermatular language was Aramaic or Syro-chaldaic, a cognate langrage, resembling Talmudic llebrew, and substantially the same as that in which part of the Books of Exa and baniel are written. 
Matthew is the translation? And with this is closely connected another important question, What was the nature of the "Gospel according to the Hebrews" used by the Hebrewspeaking Christians, so often referred to and quoted by the Fathers, and which has for centuries been lost? ${ }^{1}$ Was it, as many critics suppose, the original Aramaic Gospel of Matthew, of which ours is only the translation?

With regard to the language of the Gospel of Matthew, the external evidence is entirely in favour of an original Hebrew Gospel. The testimonies of the Fathers are manimous. Papias (A.D. 120), in the passage preserved by Eusebins, so often quoted, and which has proved so fruitful of conjectures, writes: "Matthew wrote the oracles in the Hebrew dialect, and everyone translated them as he was able.". We have endeavoured to show that by the "oracles" is most. probably meant the Gospel $;^{3}$ and if so, we have in this testimony of Papias an assertion of its Hebrew origin. "Everyone," he says, that is, every Greek Christian who was ignorant of Hebrew, "translated them as best he could." Irenaus (A.D. 180) writes: "Matthew published his Gospel among the Hebrews in their own dialect." ${ }^{4}$ Eusebius relates that Pantæmus (A.D. 200), the chief of the catechetical school of Alexandria, having gone to the Indians to diffuse the Christian religion, found among them the Gospel of Matthew; for Bartholomew, one of the apostles, had before his arrival preached the gospel to them, and left with them the writings of Matthew in the Hebrew language, which they had preserved till that time. ${ }^{5}$ The same statement is made by Jerome. ${ }^{6}$ Origen (A.D. 230), in a passage preserved by

1 Considering the remarkahle discoveries which have lately been made, there is nothing extravagant in supposing that this Gospel of the Hebrews may yet be found. This would be of great importance, would solve many difficulties, and throw a flood of light on the synoptic problem.

2 Eusebius, Hist. Eccl. iii. 39. Vide suma, p. 19.

3 Tide supra, I. 65.

${ }^{4}$ Irenæus, Adv. Har. iii. 1 ; Euselius, Hist. Eccl. v. 8: ó $\mu \dot{\varepsilon} \nu$ òn

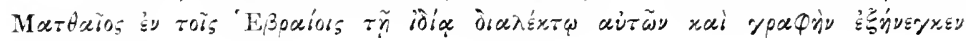
sủarystílou.

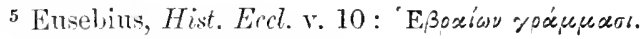

"De Fir. Illestr. ch. xxxvi. 
Eusebius, writes: "Among the four Gospels, which are the only indisputable ones in the Church of God, I have learnt by tradition that the first was written by Matthew, who was once a publican, but afterwards an apostle of Jesus Christ, who delivered it to the Jewish believers, composed in the Hebrew langnage." 1 Eusebius (A.D. 325) also attests the Hebrew original of Matthew's Gospel. "For Matthew having first preached to the Hebrews, when he was abont to go to other nations delivered to them the Gospel in their native tongue." - Cyril of Jerusalem (A.D. 345) says: "Matthew, the author of the Gospel, wrote it in the Hebrew langnage." ${ }^{3}$ Epiphanius (A.D. 348) writes: "They (the Ebionites) also receive the Gospel aceording to Matthew, and this is the only one they use. They eall it the Crospel according to the Hebrews: for the truth is that Matthew is the only one of the New Testament writers who published his Gospel in the Hebrew language and in Hebrew characters." 4 Augustine (A.D. 380) observes: "Of these four (evangelists) only Matthew is reckoned to have written in the Hebrew language; the others in Greek." 5

But the most important testimony is that of Jerome (A.D. 390), both on aecount of his intimate acquaintanee with Hebrew, and on account of the minuteness of his statement. He not only asserts that Matthew wrote his Gospel in Hebrew, but that he himself possessed a copy of it, and translated it into Greek. "Matthew, also ealled Levi, who from being a publican became an apostle, first of all wrote a Gospel of Christ in Judiea in Hebrew letters and worls for the sake of those of the circumeised who believed. Who afterwards translated it into Greek is uncertain. Moreover, this very Hebrew Gospel is in the library at Casarea, which was collected with great care by Pamphilus the martyr. With permission of the Nazarenes, who live at Beroa in Syria, and use that volume, I took a eopy." " And again: "The

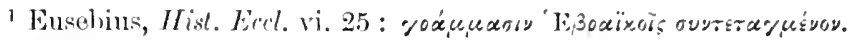

2 Ihid. iii. 24.

${ }^{3}$ Catechet. 14.

1 Epiphanius, Mer. xxx. 3. "Consensus erougelistorum, i. 2. 4.

"De Vir. Illustr. ch. iii.: Matthers, qui et levi, ex publicano Apostolus, primus in Judea popter eos qui ex circumcisione credi- 
Gospel which the Nazarenes and Ebionites use, which we lately translated from Hebrew into Greek, and which is called by most the authentic Gospel of Matthew." 1 The testimony of the later Fathers, of Chrysostom, Athanasius, Gregory of Nazianzus, and Theophylact, are to the same effect.

Thus, then, the external evidence is entirely in favom of an original Hebrew Gospel of Matthew. All the Fathers, from Papias to Jerome, and from Jerome to Theophylact, attest that Matthew wrote his Gospel in Aramaic, and that the Greek Gospel, which we now possess, is only a translation. Nor is there any contrary testimony; not one of the Fathers speaks of an original Greek Gospel. "No matter of fact," observes Greswell, "which rests upon the faith of testimony can be considered certain, if this is not so." 2 Bishop Westcott wites: "Till it can be shown that the writers quoted are untrustworthy generally, it is purely arbitrary to reject their statement hecanse it is not sufficiently explicit." 3 And Tregelles observes: "If early testimonies and ancient opinion unitedly are to have some weight, when wholly uncontradicted, then it must be admitted that the original language of the Gospel of Matthew was Hebrev, and that the text which has been transmitted to us is really a Greek translation." 4 Besides, it is to be observed that there is an antecedent probability that Matthew would write his Gospel in Hebrew. If he wrote chiefly for the Hebrew Christians, and if Hebrew was the vernacular language of Palestine, as we shall afterwards see was most probably the case, then the probability is that he would write in that language.

derant Evangelinm Christi Hebraicis literis rerbisque composuit; quod quis postea in Græecum transtulerit, non satis certum est. Porro ipsum Hebraicum haletur usque lodie in Carariensi hilblotheca, quam Pamplilus martyr studiosissime confecit. Mihi quoque a Nazareis qui in Berca urbe Syria hoc volunine ntuntur, rescribendi facultas fuit.

${ }^{1}$ Comment. ad Matth. xii. 13: Erangelium quo utuntur Nazareni et Elionita, quod nuper in Grecum de Hebreo sermone transtulimus et quod rocatur a pleriscue Matthei authenticum.

"Greswell's Harmony of the Gospels, vol. i. p. 101.

3 Westeott, Introduction to the Study of the Gospels, 1. 208, note 2.

4 Smith's Dictionary of the Iible, vol. iii. p. 1623. Article, "Versions, Ancient (Greek)." 
Nevertheless, this evidence, apparently so strong and unanimous, has been disputed hy the majority of modern critics. Papias, it is said, is described by Eusebius as a man of very limited understanding, ${ }^{1}$ and certainly many of his statements recorded by Eusebius seem to prove this; that, however, is no reason why we should refuse credence to his assertion of a matter of fact, that Matthew wrote his oracles in Hebrew. Irentus, it is suggested, may have founded his opinion on the testimony of Papias, whom he held in high estimation: but for this there is no proof; it is a mere conjecture. The statement abont Pantienus, given by Eusebins, has been discredited as mythical; it is, however, a statement independent of Papias: and if it be a legend, yet it presupposes the prevalence of the belief in a Hebrew Gospel. Origen, the only one of the Fathers before the fourth century who was skilled in Hebrew, and thus qualified to judge, gives his testimony as a tradition: "he had learned by tradition

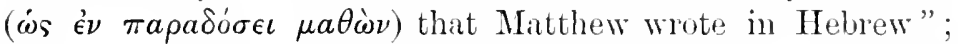
but this tradition presupposed the prevalent belief regarding a Hebrew Gospel in the time of Origen. The strongest testimony is that of Jerome. He affirms that he had the Hebrew Gospel in his possession; and not only so, but that he took a copy of it and translaterl it into Greek. An attempt has been made to nentralise this statenent. It has been asserted that if this Helnew Gospel was the same as omr Greek Gospel of Matthew, there would have been no reason for its translation. It would aplear, besides, that Jerome vacillated in his opinion. At first, when he obtained possession of the Crospel of the Nazatrenes, he believed that it was the Hebrew Crospel of Matthew; but afterwards, when he eame to examine and translate it, he expresses himself hesitatingly, and gives his judgment in a modified form. "The Gospel which the Nazarenes and Ebionites nse is called ly most (" plevisque) the anthentic Gospel of Matthew." "The Gospel

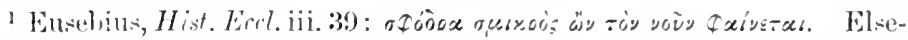

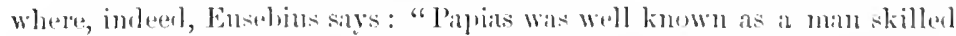
in all manner of leanning, and well atcouninted with the serigutures," iii. 36. But this sentence is now regabled ats sputious.

2 comment. ad. Wutth. 
according to the Hebrews, written in the Syro-Chaldaic language, but in Hebrew characters, which the Nazarenes use, is by most supposed (ut plerique autumant) to be the Gospel according to Matthew." 1 Now, it is admitted that there is some ambiguity in the language of Jerome, and that he appears to have confounded the Gospel of Matthew with the Gospel according to the Hebrews, regarding them as the same. But, notwithstanding this ambiguity, which certainly weakens his testimony, he still holds to the opinion that the original Gospel of Matthew was written in Hebrew. The relation of these two Gospels - the Gospel according to the Hebrews and the Gospel of Matthew-is reserved to form the subject of future consideration, in order not to interrupt the course of this. cliscussion.

Ijut whilst the external evidence, as contained in the testimonies of the Fathers, is wholly in favour of an original Hebrew Gospel of Matthew, the internal evidence is to the contrary effect; and it has been atfirmed that the Gospel of Matthew, as we now possess it, must have been an original document, and could not have been a translation. Some of the arguments in proof of this are not convincing, but others are undeniably strong.

1. It is affirmed that from its mature the Greek text of our Gospel camnot have been a translation from the Hebrew. It bears no marks of being a translation: the style is clear and flowing, without the slightest stiffness, bearing the impress. of originality. There are in it numerous explanations of Jewish customs which would have been umnecessary had the Gospel been written in Hebrew for Hebrew converts. Thus: "On that day came to Him Saddncees, who say that there is no resurrection" (xxii. 23). "That field was called, The field of blood, unto this day" (xxvii. 8). "Now at the feast the governor was wont to release unto the multitude one prisoner, whom they would" (xxvii. 15). "This saying" was spread abroad among the Jews, and continueth until this day" (xxviii. 15). Further, if the Gospel was written originally in Aramaic, there would have been little use of a Syriac translation, as it would be understood by the Syrian Chris${ }^{1}$ Dialog. adv. Pelagianos, iii. 2. 
tians; or at least the Syriac translation would lave been made from it, and not from the Greek, which on this hypothesis was itself a translation. "We have," ubserves I'rofessor. Moses Stuart of America, "the P'eshito, a version of a very early age, in a linglage which was twin-sister to the Hebrew of that diy, yea, almost identical with it: and yet this version is demonstrably not from a Hebrew original of Matthew, but from the present Greek canonical Matthew." Besides, it is the present Greek text that is uniformly quoted or referred to by the Fathers, and that at a period so early as the time when the Epistle of Barnabas was written (A.n. 100). There are also paronomasix, or plays on Greek words, whieh could

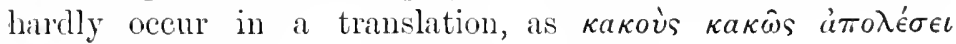

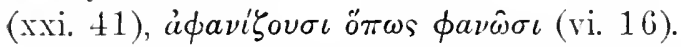

To these objections it is answered: that the excellence of the translation may remove all traees of its having been written in a foreign language; that the explanation of Jewish customs was necessary for those Jewish converts who lived outside of Palestine and used the Hebrew language; that the Fathers quoted from the Greek because it was before them, whilst they may not have seen the Hebrew original, which might not lave been eirculated beyond Palestine: and that paronomasice are very few, and may ocenr in translations as well as in the original. We have a remarkable instance of a paronomasia in the Anthorised Version of Jas. i. 6: "But let him ask in faith, nothing wavering; for he that wavereth $\left(\delta a \kappa \rho \iota{ }^{\prime} \mu \epsilon \nu o s\right)$ is like a wave $\left(\kappa \lambda v^{\prime} \delta \omega \nu \iota\right)$ of the sea driven with the wind and tossed." 1

2. There are in the Gospel of Matthew several Aramaic expressions, the translations of which are subjoined. Thus: "They shall call His name Immanel, which is, being interpreted, Ciod with us" (i. 23). "They eame unto a place called Colsotha, that is to say, The place of a skull" (xxvii. 33). "Eli, Eli, lama salbiehthani? that is, My God, My Gorl, why hist Thou forsaken Me?" (xxrii. 46). These Aramaic expressions may have been preserved in the Greek fosprel on aceount of their weighty character; but the interpretation of them conld not have formed part of a Hebrew I so alis, in Rrm. ii. 18. 
original. To this objection, two answers are given: The translation of these Aramaic expressions may have at first been put as a marginal note for the information of Greek readers, and afterwards have been inserted in the text. For this, however, there is no critical authority, as they are found in all manuscripts. Or the translator of the Hebrew original might himself have given the interpretation; a supposition which is not improbable.

3. A far more formidable objection to a Hebrew original arises from the fact that there is often an identity between the Greek of Matthew's Gospel and the Greek of the Gospels of Mark and Luke. This, it is evident, could not possibly have been the case if the Greek Gospel of Matthew was an independent translation. A Hebrew original of Matthew may account for a variation in his Gospel in the narrative of the same events and discourses contained in the other Gospels, but the agreement in expression is a proof that the Gospel of Matthew could not be an independent translation. If Matthew and Luke use precisely the same words, as is often the case, it is a proof that both had the same Greek source before them.

Here, undoubtedly, there is an objection to an original Hebrew Gospel of great force, and the answers given to it are somewhat unsatisfactory. Meyer gives the following answer: "The frequent identity of expression in Matthew with Mark and Luke does not necessarily point to an original composition of the former in Greek, but leaves the question quite unaffected, as the translated Matthew might either have been made use of by the later Synopties, or might even have originated from the use of the latter, or of common sources." 1 According to this distinguished critic, either Mark and Luke may have made use of the translation of Matthew, or the translator of Matthew may have used these Gospels, or all three may have drawn from common sources. But none of these suppositions can be correct. The Gospel of Luke, we have seen, was independent of that of Matthew; ${ }^{2}$ and to suppose that the translator of the Hebrew Matthew drew from the

I Meyer's Commentary on Matthew, 1. 10, translation.

2 See supra, p. 50. 
same common source as Luke, may not incleed be an impossible, but is a highly improbable supposition, and detracts from the value and accuracy of the translation.

Some attempt to solve this difficulty, arising from the conflict between the external and internal evidences regarding the language of Matthew's Cospel, by the assumption that Matthew wrote two editions of his Gospel, the one in Hebrew, for the use of Christians who spoke Hebrew, and the other in Greek, for the use of Christians who spoke Greek. This hypothesis of a twofold Cospel of Matthew is of comparatively recent origin, and has $n o$ support from the writings of the Fathers, who never attribute the translation of the Gospel to Matthew himself. It is, however, very plausible and not indefensible, because, if adopted, it at once reconciles the declarations of the Fathers concerning an original Hebrew Matthew with the proofs that our present Gospel was written in Greek; the external and internal evidences are brought into agreement. ${ }^{1}$ Such a theory, with various modifications, has been adopted by such distinguished critics as Bengel, Sehott, Olshausen, Thierseh, Guerieke, and Schaff; and among English theologians by Townson, Whitby, Benson, Bloomfield, Horne, Arehdeacon Lee, ${ }^{2}$ and Bishop Ellieott. Thus Schaff writes: "If we credit the well-nigh unanimous tradition of the ancient Church eoncerning a prior Hebrew Matthew, we must either aseribe the Gospel of Matthew to some unknown translator who took certain liberties with the original, or what seems most probable, we must assume that Matthew himself, at different periods of his life, wrote his Gospel first in Hebrew, in Palestine, and afterwards in Greek. In doing so, he wonld not literally translate his own book, but, like other historians, freely reproduce and improve it. Josephus did the same with his history of the Jewish war, of which the cireck only

${ }^{1}$ If we camnot pritively assent to its truth, yet neither can we rejeet it, lint, on the contrary, may faromally entertain it as a solution of difticulties. "There seems," olserven 1)r. T'own:on, "more renson for allowing two originals than for contesting either: the consent of antignity pleathing strongly for the flemew, and exident marks of originality for the (rrecek."

- Dr Lee, Inspiration of the Holy Seripture, 1p. 5ti6-5it. 
remains. ${ }^{1}$ When the Greek Matthew once was current in the Church, it naturally superseded the Hebrew, especially if it was more complete." 2

Others, admitting that Matthew wrote his Gospel in Hebrew, in order to give apostolic authority to the translation, assign it to different apostles. Thus the author of the Synopsis Scripture sacre, in Athanasins' works, assigns it to James; Theophylact, to John; Anastasius Sinaita supposes that Panl and Luke conjointly translated the Gospel into Greek. Gresswell makes the strange supposition that Mark was the translator of the Hebrew Matthew. ${ }^{3}$ All these are mere fanciful conjectures. Another opinion is that the $\lambda$ óyıa or oracles of Matthew mentioned by Papias was not the Gospel of Matthew, but another work of his written in Hebrew, containing chiefly discourses of onr Lord, which he afterwards translated and embodied in his Gospel written in Greek. ${ }^{4}$

It is exceedingly difficult to arrive at any certain conclusion as the result of this discussion. On the one hand, the external evidence in farour of an original Hebrew Gospel is uniform and undisputed: the Father's are manimous on this point, and there is no contrary testimony. But, on the other hand, the internal evilence in favour of an original Greek Gospel is so strong and apparently so convincing, that were it not for the external evidence it would hardly have been doubted. The attempt to overthrow the external evidence by asserting that the Fathers, following the assertion of Papias, were mistaken, is a violent solution; the testimony of Origen, for example, cannot in this manner be set aside. A possible solntion may be that the Gospel aceorling to the

1 So also Ihne wrote his excellent history of the Romans both in German and in English. They were separate works: the English was, not a translation of the German.

2 Schaff's Church History, rol. i. 1. 626.

${ }^{3}$ Greswell's Dissertations, rol. i. 1. 122. He gives it as his conjecture that "Mark translated the Hebrew Gospel of Matthew, and wrote his own supplementary to it, either both at Rome, or both about the same time."

* For this ingenioussupposition, see Morison's Commentury on Matthew, Introduction, ple. xlvf. 
Hebrews may have been originally the Hebrew Gospel of Matthew, but afterwards becime much altered from its original form by interpolations and omissions. In general, greater weight must be given to the external evidence which relates to matters of fact than to the internal evidence which, for the most part, rests on subjective considerations.

Crities are nearly equally divided upon this question. Grotius, Eichhorn, Kninoel, Michnelis, sieffert, Thohek, Olshausen, Meyer, Ebrard, Ciolet, Lange, and Luthardt; and anong English theologians, Walton, Mill, Principal Campbell of Aberleen, Greswell, Norton (of America), Tregelles, Cureton, Dr. Simuel Davirison, and Westcott, maintain the Helsew original of the Gospel. Whilst the Greek original is maintained by Erasmus, ${ }^{1}$ Beza, Wetstein, Hug, Credner, De Vette, Ewald, Bleek, Tischendorf, Holtzmamn, Zahn, and Weiss; and among English writers by John Lightfoot, Larduer, Jones, Moses Stuart (of America), Arehbishop) Thomson, Alford, Morison, Roberts, and Salmon.

Another important point, intimately related to this discussion, remains to be eomsidered : the natme of the Crospel

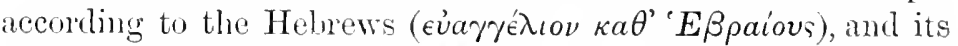
relation to the Cospel of Matthew. Many erities suppose that this Crospel, divested of its apocryplal additions, and having its omissions restored, was the original Hebrew Gospel of Matthew, and that our canonical ciospel is a translation of it before it was mutilated. Indombtedly such a Gospel was in use among the Hebrew-speaking eonverts at at rery early period. It is often quoted by the Fathers, and was lelel in estimation amomg them, being sometimes cited as Scriptmre. It necurs moler various names, an "the Ginspel of the Elbionitrs," "the Guspel of the Nazallenes," and "the (rospel of the Twolve Apustles." Its migin is uhsenre. Some smprose that it is cited by Ignatius in his Epistle to the sinymenns, when, in olposition to thr bocetic conception of wm Lord's lwaly, he silys that omr Lond, after His resurection, said to His disciples: "Lay hold, handle Me, and see

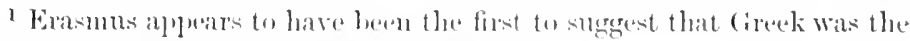
original langutag of the (ropel of Matthell. 
that I am not an incorporeal (lemon." 1 Eusebius states that he knew not whence Ignatius derived his information ${ }^{2}$ but, according to Jerome, it was a quotation from the Gospel of the Nazarenes. ${ }^{3}$ The probability, however, is that the reference is to Luke xxiv. 39: "Handle, and see; for a spirit hath not flesh and bones, as ye behold Me having." Eusebius informs us that Papias gives us an account of a woman who had been accused of many sins before the Lord, which is contained in the Gospel according to the Hebrews. ${ }^{4}$ It is to be observed that Eusebius does not here affirm that Papias quoted this statement from the Gospel according to the Hebrews, but merely that such a statement is to be found in that Gospel. The first direct testimony to the existence of such a Gospel is contained in the somewhat ambiguous statement of Eusebius concerning Hegesippus (A.D. 180). "He (Hegesippus) states some particulars from the Gospel according to the Hebrews, and from a Syriac Gospel, and particularly from the Hebrew language, showing that he himself was a convert from the Hebrews." ${ }^{5}$ Ireneus (A.D. 180 ) states that the Elionites used the Cospel according to Matthew only, and repudiated the Apostle Paul, maintaining that he was an apostate from the law. ${ }^{6}$ In these words of Irenxus we have an evident reeference to the Gospel of the Ebionites (the same as the Gospel according to the Hebrews), which was attributed to Matthew. It was accordingly in existence in the time of Irenæus, and appears to have been regarded by him as the Hebrew Gospel of Matthew. Clemens Alexandrinus writes: "Natthew, in the traditions exhorting us, says, Wonder at what is before you, laying this (namely, wonder) down as the foundation of all further knowledge. So also in the Gospel to the Hebrews it is written, He that wonders shall reign, and he that has reigned shall rest." 7

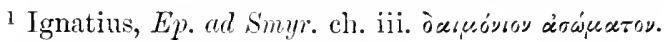

2 Eusebius, Hist. Eccl. iii. 36.

3 De viris illustr. ch. xvi.

${ }^{4}$ Eusebius, Hist. Eccl. iii. 39.

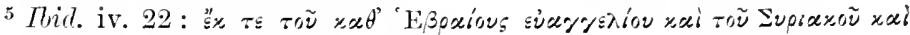

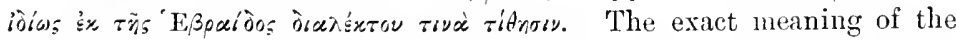
words is very difficult to determine. May it not be that Hegesilpus alludes to the Syriac version?

${ }^{6}$ Irenzens, Adv. Hor. i. 26. 2. $\quad 7$ Clemens Alex. Stromata, ii. 9. 
Origen spealis of this (iospel in donlitful terms: "If anyone admit the Gospel according to the Hebrews." 1 "It is written in a certain Gospel, which is entitled, "according to the Hebrews,' if anyone please to receive it, not as of anthority, but for illustration." 2 Eusebius classes it among the vó or spurions writings: "In this number some have placed the Gospel according to the Hebrews, with which those of the Hebrews who have received Christ are particularly delighted." 3

The strict Jewish Christians, who held that the law of Moses was not abolished, but still binding on all Christians, and who refused to hold communion with the Gentile converts, separated of their own aecord from the Catholic Church, soon after the destruction of Jernsalem, or were cast ont. They are known in ecclesiastical history as Ebionites. ${ }^{4}$ Irenreus is the first who mentions this sect: "Those who are called Ebionites agree that the world was made by God; but their opinions with respect to the Lord are similar to those of Cerinthus and Carpocrates. They practise circumcision, persevere in the observance of the customs which are enjoined by the law, and are so Judaic in their style of life that they even adore. Jerusalem, as if it were the house of God." 5 After their separation from the Catholic Church, they adopted virious heretical opinions. They held low views of Christ, denied His divinity, regarding Him as the son of Mary born in wedlock, ant rejeeted the Epistles of Paul. There seems, however, to have been at an early period a diversity of opinion among them. Thus Origen observes: "Let it be admitted that there are some who accept Jesus, and who boast on that account of being Christians, and yet would regulate their lives like the Jewish multitude in accordance with the Jewish law, and these are the twofold sect of the Ebionites, who either ackmowledge with us that Jesus was born of a virgin, or eleny this, and

1 Comment. ad Jomm.

2 Origen on Matt. xix. 19.

${ }^{3}$ Eusehins, Hist. Eewl. iii. 25.

"According to Tertullian, the Ebionites were the disciples of a leretic aller Ebion; but it is nore prolable that the word is an alpellative meininger poor.

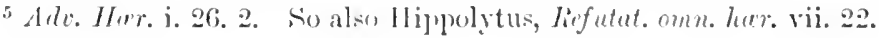


maintain that $\mathrm{He}$ was begotten like other human beings." 1 And the same distinction is made by Ensebius: "The Ebionites," he observes, "hold poor and mean opinions concerning Christ. They considered Him a plain and common man, who was justified only because of His superior virtue. There are others besides them who were of the same name, but avoided the absurdity of these opinions, not denying that the Lord was born of a virgin." 2 Epiphanius is the first Father who calls these two classes by different names: those who held heretical opinions concerning the person of Christ he terms Ebionites, and those who held comparatively orthodox views he terms Nazarenes. ${ }^{3}$ I'robably the heretical views of the Ebionites were of later growth, as Justin describes the strict Jewish Christians only as weak brethren who had not attained to the liberty of the Gospel. ${ }^{4}$ In accordance with this difference of opinion, there appear to have been two recensions of the Gospel according to the Hebrews, the one called the Gospel of the Ebionites, and the other the Gospel of the Nazarenes; ${ }^{5}$ and there is also a difference in the quotations from them as given by Jerome and Epiphanius. It was the Gospel of the Nazarenes that Jerome translated.

Mr. Nicholson, in his learned work, The Gospel according to the Hcbrexs, ${ }^{6}$ supposes that it was written by Matthew, and that he also wrote the Greek Gospel that bears his name. The one was an edition of the other, just as modern authors publish editions of their works, often much altered. " $\mathrm{My}$

1 Contra Celsum, v. 61.

${ }^{2}$ Hist. Eccl. iii. 27. These two classes are to be identified with the Ebionites and Nazarenes. See De Wette's Einleitung, $\$ 63 a$.

${ }^{3}$ Her. xxx. 3. $13 . \quad{ }^{4}$ Dial cum. Tryph. eh. xlvii.

${ }^{5}$ According to a statement of Epiphanius, the language of the Eljionite Gospel would appear to have been Greek, Horr. xxx. 3. 13, an opinion adopted by Hilgenfeld. This, however, is very doubtful. The language of the Nazarene Gospel was undoubtedly Hebrew.

"This is a work of great erurtition which has been too much overlooked. In it there is a most valuable collection of all the fragments of this Gospel, scattered throughout the writings of the Fathers, with valuable critical amnotations. He gives thirty-three fragments, many of them of a highly interesting character. See also Anger in his Synopsis Evangeliorum. 
hypothesis," he observes, "is that Matthew wrote at different times the eanonical (rospel and the (rospel aceording to the Hebrews, or at least that large part of the latter which runs parallel with the former." 1 Afterwarls, as he supposes, the (iospel of the Hebrews beeame eorrupted with additions," abbreviations, and heretical views; but in its original state it was the Hebrew Grospel of Mattlew.

It wond certainly appear that the Gospel of Matthew lies at the foundation of the Gospel accurding to the Hebrews, whether in its corrupt state as used by the Ebionites, or in its comparatively pure state as used by the Nazarenes. For this we have the distinct testimonies of Epiphanins and Jerome. The Ebionite Gospel, or the Gospel of the Hebrews in its corrupt form, as is evident from the extracts from it and references to it contained in the writings of the Fathers, is clearly heretical, and is to be classed among the spurious Gospels, being a mutilation of the Gospel of Matthew, just as the Gospel of Marcion was a mutilation of the Gospel of Luke. On the other hand, Epiphanius informs us that the Nazarenes had the Gospel of Matthew in a compratively complete form in Hebrew." The question then naturally arises: Might not this Crospel of the Hebrews, as preserved by the Nazarenes in its original state, when divested of its accretions and with its omissions restored, be the Hebrew Gospel of Natthew attested by the Fithers, and which was lost after its translation into Greek? This, however, is exceedingly doubtful, as the fragments of it which remain are additions which find no place in our canonical Cruspel."

Some of these additions fomm in the writings of the

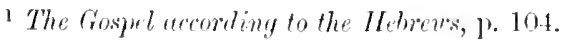

2 Many of these extra canonical alditions Mr. Nicholson defents, and supposes to he grenume.

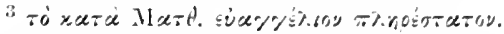

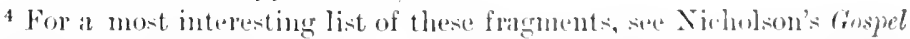

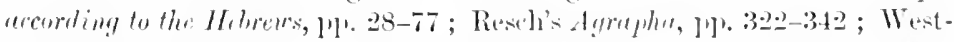

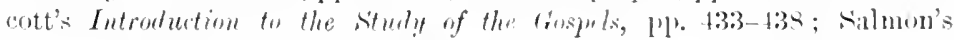

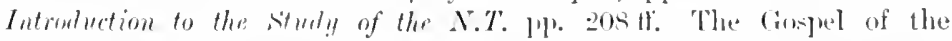

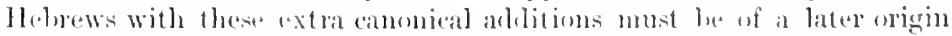

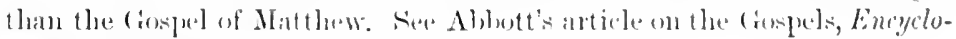
Imeliue Britomiter, vol. x. 1. 818, note. 
Fathers are of an interesting nature. We give a few examples. The man with the withered arm is described as a mason, who came to Jesus saying: "I am a mason, seeking a livelihood by the labour of my hands. I pray thee, Jesus, to restore me to health, that I may not beg my bread." ${ }^{1}$ The Holy Spirit is called " the mother of Christ." The Lord is introduced as saying: "My mother, the Holy Ghost, lately took Me by one of the hairs of My head and earried Me to the great mountain Tabor." 2 The aecount of the rich man who came to Jesus asking, What must I do to inherit etemal life, is thus expanded: "Another rich man said unto Him, Master what good thing must I do to live? He said to Him, Fulfil the law and the prophets. He answered Him, I have fulfilled them. He said to him, Go, sell all that thou hast, and distribute to the poor, and eome follow Me. But the rich man began to scratch his head, for it pleased him not. Then said the Lord to him, How sayest thou I have fulfilled the law and the prophets, seeing that it is written, Thou shalt love thy neighbour as thyself; and behold many of thy brethren, the sons of Abraham, are clothed in filth, and dying from hunger, whilst thy house is full of mueh goods, and nothing goes out of it. And He turned and said to Simon, sitting beside Him, Simon, son of Jonas, it is easier for a camel to enter through the eye of a needle, than for a rich man to enter into the kingdom of heaven." 3 It is in this Gospel that the legend of our Lord's appearance to James is found. It is given as follows: "And when the Lord had given His linen eloth to the servant of the high priest, He went to James and appeared to him. For James had taken an oath that he would not eat bread from that hour on which he had drunk the cup of the Lord until He saw Him risen from the dead. Then our Lord said, Bring a table and bread. And He took the bread, and blessed, and brake it, and gave

1 This is found in Jerome, wh Matth. xii. 13. See Resch's Agraphu, 1. 379 ; Nicholion, p. 46.

${ }^{2}$ Found in Origen, Comm. ad. Johann. \$ 63. See Nicholson, pp. 74-76.

${ }^{3}$ This passage is found in the Latin version of Origen's commentary on St. Natthew ; see Resch's Ayrapha, P. 387 ; Wescott's Introduction to the Gospels, p. 434; Nicholson's Gospel according to the Hebrexs, 1'l. 49-51; Salmon's Introduction, p. 213. 
it to James the Just, saying, Eat thy bread, My brother, for the Son of Man is risen from the clead." 1

Another important point, intimately connected with the subject under discussion, regards the language spoken in Palestine in the days of Christ and His apostles. Hug was among the first to maintain that the prevailing language of Judra and Galilee at this time was not Arunaic but Greek, and that, consequently, if Matthew wrote his Gospel to the Jews in Palestine, he must lave done so in Crreek." This opinion has recently been maintained with much learning and ingemity by Professor Roberts of St. Anchers. He thus states his theory: "What I maintain is that Greek was the language which our Lord and His followers habitually nsed in their public addresses." "While it is generally sili that our Lord for the most part spoke in Hebrew and only sometimes in Greek, what I venture to maintain is that our Lord spoke for the most part in Greek and only now and then in Hebrew." 3 Now, certainly it must be admitted that Greek was commonly used in lalestine in the time of our Lord. The conquests of Alexander, the policy of the Roman govermment, the intercourse with Greek Jews who came to worship at the annual festivals, and the Hellenic tendency of the Herolian family, must have diffinsed the Greek language. There were mumerous cireek cities scattered throughout all Palestine, especially in the province of Galilee, called on that aceount Galilee of the Gentiles. ${ }^{*}$ Greek was the language in which legal proceedings were arried on hy the Roman govermment, and must have been used in commercial transactions with foreigners. It was doubtless the launguge in which our Lord spoke lefore Pilate. At the same time, we cam hardly assume that (ircek was the prevailing lamgnage. Palestine appears at this time to have been bilingulal; both Hebrew and Greek were spoken;

1 This tradition is fouml in Jerome's De rir. illustr. ii. For remarks

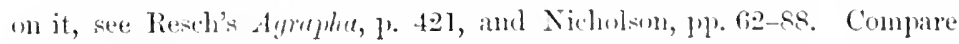
1 (C). x. . T.

"Ilug's Introduction to the A.T. vol. ii. 1. 5. If.

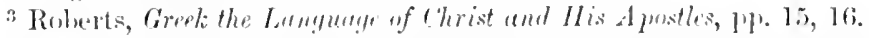

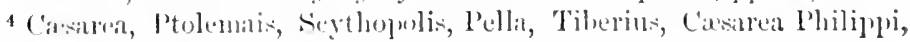
Samaria, Antipatris were liteck cities. 
Hebrew probably by the country people, and Greek by the educated and those residing in towns; as is the case with the Celtic and English in the Highlands of Scotland, and with the Welsh and English in Wales. Paul in addressing the Jewish mob in Jerusalem, spoke to them in the Hebrew tongue, in consequence of which he was heard with greater attention (Acts xxii. 2). And in his address before Agrippa he mentions that the voice which came from heaven at his conversion addressed him in the Hebrew tongue (Acts. xxvi. 14). The few words of our Lord which have been preserved are Aramaic, apparently intimating that this was the language in which He generally spoke: as Cephas, Boanerges, Ephphatha, Talitha-cumi, and the exclamation on the cross, Eli, Eli, lama sabachthani. So also we learn the same use of Helrew by the people from the writings of Josephus. He wrote his history first in Hebrew, which he calls his native language, and then in Greek. "I propose," he says, "to narrate in the Greek language to those under the Roman dominion the things which I formerly composer for the barbarians of the interior in my native tongue." 1 And whilst he calls Helrew his native tongue ( $\pi \dot{\tau} \tau \rho\llcorner o s \gamma \lambda \omega \sigma \sigma a)$, he speaks of Greek as a foreign language ( $\left.\xi^{\prime} \dot{\nu \eta} \delta \iota a ́ \lambda \epsilon \kappa \tau o s\right) .{ }^{2}$ When, at the request of Titus, he addressed his countrymen, it was in Hebrew: "Josephus, standing where he could be heard, declared the message of the emperor in Hebrew." 3 From all this it would appear that although Greek was well known to the Jews, and they conld converse in it, yet their native language, that which they usually employed in mutual intercourse, was not Greek but Aramaic, called in Scripture "their language" (Acts i. 19). ${ }^{4}$

We have already had occasion to refer to the style and diction of Matthew. There is a frequent recurrence of peculiar expressions. The phrase, "that it might be fulfilled which was spoken of the Lord by the prophets," is of constant

${ }^{1}$ Josephus, Boll. Jud. Preface. $\quad 2$ Ant. Preface. ${ }^{3}$ Bell. Jud. vi. ‥ 1.

4 For the extent to which Greek was spoken in Palestine, see Schürer's Jewish I'eople in the Time of Christ, div. ii. vol. i. pp. $47 \mathrm{ff}$. He comes to the conclusion that the lower classes in Palestine possessed either no knowledge, or only an insufficient one, of Greek. 
occurrence. The expression, "the Son of David," the Mes-

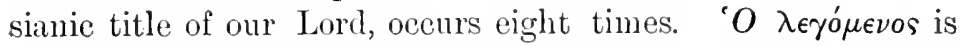
a favourite expression, amnouneing the meaning of the epithets applied to Christ and His disciples. "The kingdom of heaven" is used in this Gospel instead of "the kingdom of God" employed by the other synoptists. The phrase, $\sigma \nu \nu \tau \in \lambda \epsilon i a$ rov aî̀vos, occurs four times, and is only found elsewhere in Heb. ix. 26. Tádos is the word for a tomb, which oceurs six times, and is never used by the other

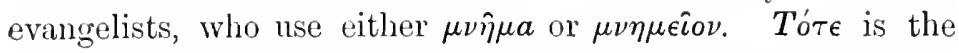
nsual particle of transition. There is also a large number of words which are peculiar to this (rospel. ${ }^{1}$ Hebraisms oceur, but not more frequently than in many other writings of the New Testament, and are not suffieiently numerous to indicate traces of a translation from the Hebrew. "The style of Matthew," writes Schaff, "is simple, unadorned, calm, dignified, even majestic: less vivid and picturesque than that of Mark, more even and uniform than Luke's, because not dependent on written sources. $\mathrm{He}$ is Hebraising, but less so than Mark, and not so much as Luke in his first two chapters. In the fulness of the teaching of Christ he surpasses all except John. Nothing can be more solemn and impressive than his reports of those words of life and power, which will outlast heaven and earth (xxiv. 34). Sentence follows sentence with overwhelming force, like a succession of lightning thashes from the upper world." 2

\section{Integrity of the Gosiel.}

1. The principal passage in the Gospel of Matthew, the genumeness of which has been disputerl, is the first two chapters, containing the genealogy of our Lord and the narrative of Mis birth. Doulsts were first thrown upon the apostolic origin of this passage toward the close of last century (A.D. 1771) by an Englishman named Williams, in a work

1 For the characteristic words and expressions in Yatthew's Gospel, sce Credner's Einleituny in de.: N.T. pp. $62-59$; Davids m's Introduction to the sturly of the N.T. 3rit erl. vol. i. 119. 371-379.

"Schatr's Chureh IIistory, vol. i. 1) 620. 
entitled, A free inquiry into the authenticity of the first and second chapters of St. Matthew's Gospel. He was followed in Germany by such distinguished critics as Eichhorn, Schleiermacher, and Bertholdt, and by Priestley and his school in England. Andrews Norton of America, an Arian, though belonging to the positive school of criticism, supported the same opinion. He conceived that these two chapters did not form a part of the original Hebrew Gospel, but were an extraneous document inserted by the translator into the Greek Gospel. "There are," he observes, "strong reasons for thinking that the first two chapters of our present copies of the Greek Gospel of Matthew made no part of the original Hebrew. We may suppose them to have been an ancient document, which, from the connection of the subject with his history, was transcribed into the same volume with it, and which, though first written as a distinct work with some mark of separation, yet in process of time became blended with it, so as apparently to form its commencement. Being thus found incorporated with the Gospel in the manuscript or in manuscripts used by the translator, it was rendered by him as part of the original." 1 So also Meyer, while admitting that the passage formed an integral portion of the Hebrew Gospel, of which our eanonical Gospel is the translation, yet calls in question its apostolic anthority. "The portions composing both chapters," he says, "were originally special Gospel locuments. Ch. i. 1-16 appears to have been one such document by itself, then vv. 18-25 a sccond, and ch. ii. a third, in which are now found for the first time the locality and time of the birth of Jesus." 2 He appears to regard it as a legendary account which found admission into the Gospel. The passage has been defended by Griesbach, Miiller, ${ }^{3}$ and Alford, and even by such rationalistic crities as Credner, Paulus, ${ }^{5}$ and Kuinoel. ${ }^{6}$

${ }^{1}$ Norton, The Genuineness of the Gospels, rol. i. p1. 16, 17.

2 Meyer's Commentary on Matther, Eng. trans. vol. i. p. 80.

"Ueber die Aechtheit der waei ersten Kapitel des Evang. nach Mutth.

${ }^{4}$ Einleitung, p. 68.

${ }^{5}$ Exegetisches Handbuch, vol. i. 1) 137.

" Novi Testamenti Libri Historici : Prolegomena, § 3, De authentia, cap. i. et ii. Evangelii Matthæi. 
The external objections to the genuineness of these chapters are of no weight. The chief argument is that they are not eontained in the Gospel according to the Hebrews as used by the Jewish Christians, and hence it has been inferred that they formed no part of the original Hebrew Gospel of Matthew. Epiphanius, who appears to have regarded the Gospel aceorling to the Hebrews, or as he ealls it, the Gospel of the Ebionites, as the same as the origimal Aramaic Gospel of Matthew, though in an incomplete, adulterated, and mutilated form, states that it commeneed with the baptism of John: "The begimning of their Gospel was this: It eame to pass in the days of Herod, the ling of Judrea, that John eame baptizing with the baptism of repentance in the river of Jordan" (Matt. iii. 1-7). ${ }^{1}$ We have already considered the relation of this Gospel to the Gospel of Matthew. It is not now in existence, so that we eannot verify this statement. But as the majority of Hebrew Christians were Ebionites who ealled in question the divinity of Christ, it is highly probable that from dogmatic motives they lid rejeet the first two chapters of Matthew, which tanght the miraculous conception. Tatian also, in his Diatessaron, omitted the genealogy. But this is no serions objection to the genumeness of these two chapters, sinee Tatian, although he omitted the genealogy of our Lord as not being essential to his harmony, did not omit the narrative of the birth of Christ, - the miraculous eonception, the visit of the Magi, the appearance of the star, and the slaughter of the infants of Bethlehem.

But the prineipal objections arise out of the narrative itself. The visit of the Magi and the appearance of a star are said to be of a legendary eharacter, resembling the aecounts which the heathen gave of the birth of their demigods. The massacre of the infants of Bethlehem, an act of uneximpler and unheard of barbarity, is mrecorded in history, and hesides was wholly umnecessary, as Herod might easily have aceomplished his purpose withont having recourse to such a deed of cruclty. And it is affirmed that the aceomnt of the birth of Christ as recorded by Luke is wholly different from that here ${ }^{1}$ HIter. xxx. 13. 
given us by Matthew, and that the events which follow are at variance: instead of the visit of the Magi and the flight into Egypt, there is the presentation in the temple and the return to Nazareth.

The external testimony in favour of the passage is so strong and convincing, that we do not see how it can be set aside by any objections of a subjective or internal nature. The passage is contained in all Greek manuscripts and in all the ancient versions of the Gospels. It is frequently alluded to and quoted by the early Fathers. Thus, in the Epistle of Ignatius to the Ephesians (A.D. 115), there is an allusion to the star. "How was He manifested to the world? A star shone forth in the heavens above all the other stars, the light of which was inexpressible, while its novelty struck men with astonishment." 1 Justin Martyr (A.D. 180) mentions all the incidents contained in the narrative-the visit of the Magi, the flight into Egypt, and the massacre of the infants. "Now this King Herod, at the time when the Magi came to him from Arabia, and said that they knew from a star which appeared in the heavens that a king had been born in your country, and that they had come to worship Him, learned from the elders of your people that it was written regarding Bethlehem in the prophet: 'And thou Bethlehem, in the land of Judah, art by no means least among the princes of Judah: for out of thee shall go forth the leader who shall feed my people.' Accordingly the Magi from Arabia came to Bethlehem and worshipped the child, and presented Him with gifts, gold, and frankincense, and myrrh; but returned not to Herod, being warned in a revelation, after worshipping the child in Bethlehem... So Herod, when the Magi from Arabia did not return to him, as he had asked them to do, but departed by another way to their own country, according to the commands laid on them; and when Joseph, with Mary and the child, had gone into Egypt, as he did not know the child whom 'the Magi' had gone to worship, ordered the whole of the children then in Bethlehem to be massacred." 2 As we have already stated, the whole passage, with the exception of the genealogy, is contained in the Diatessaron of

1 Ignatius, Ep. ad Ephes. ch. xix.

2 Dial. c. Tryph. ch. lxxviii. 
Tatian (A.D. 160). There are frequent referenees to it in the writings of Irencus (A.D. 180). Thus he refers to the genealogy of our Lord as recorded by Matthew: "Matthew relates His greneration as a man: The birth of the generation of Jesus Christ, the son of David, the son of Abraham: and also, The birth of Jesus Christ was on this wise." 1 And he mentions the visit of the Magi and the appearance of the star: "Natthew says that the Magi, coming from the East, exelaimed: We have seen His star in the East, and are come to worship Him." 2 It is needless to pursue the references to the passage further. There is no doubt that it constituted an original portion of the Greek Gospel of Matthew. To aftirm, with Norton, that it formed no part of the original Hebrew, but was an insertion into our Greek Gospel by the translator,granting the existence of a Hebrew original,-is a mere assertion, for which the only proof is its omission in the defective Crospel according to the Hebrews.

The internal evidence is in favour of the genumeness of the passage. It forms an appropriate introduction to the Gospel. Thus the beginning of chap. iii.: "And in those

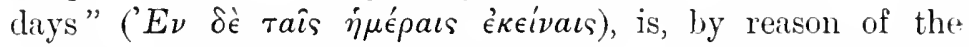

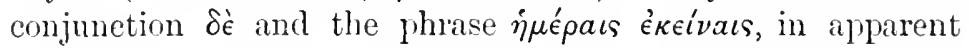
connection with what precedes. So also the statement, that Jesus leaving Nazareth, eame and dwelt in Capernam (iv. 13), presupjoses the previous residence in Nazareth mentioned in the passage (ii. 23). The style and diction of the passage eorrespond with the rest of the Cospel. The favourite formula of Matthew, when introducing any prophetie statement: "That it might be fulfilled which was spoken of

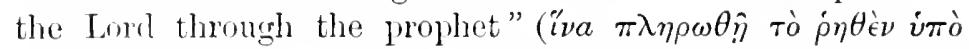

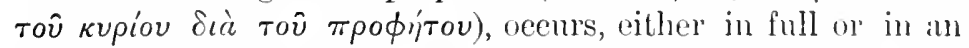
abbreviated form, five times (i. 22, ii. 5, 15, 17, 23). The Messianic title user by Matthew, the son of Diviul (vios Aavio), nceurs twice (i. 1, 20). The farourite term, $\lambda \in$ gópevos, userl in amomeing the meaning of an epithet

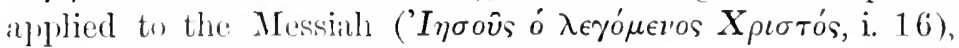

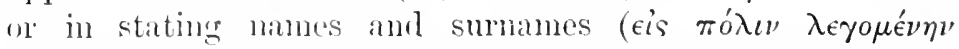
Naלapét, ii. 2::), is twice employed. The peculial nse of ${ }^{1}$ Ireniphe, Contru Herr. iii. 11. 8. 2 Ilind. iii. 9. ‥ 
$\dot{\rho} \eta \theta \epsilon i s, \dot{\rho} \eta \theta \dot{\epsilon} \nu$, occurs four times, whilst of the other Synoptists only Mark has tò $\dot{\rho} \eta \dot{\epsilon} \nu$ (Mark xiii. 14). ${ }^{1}$ Of course it may be answered, that these similarities of diction are attributable to the translator in rendering the Hebrew original into Greek. ${ }^{2}$

The visit of the Magi and the appearance of the star are objected to as being legendary, and giving countenance to the superstitious ideas of astrologer's. "In the story of the Magi," observes Norton, "we find represented a strange mixture of astrology and miracle. A divine interposition is pretended, which was addressed to the false opinions of certain Magi respecting the significance of the stars, and for which no purpose worthy of the Deity can be assigned." 3

The incident occurs as part of the continuous narrative of the evangelist; and, if we admit the supernatural in the narrative, there is no reason why it should be regarded with special suspicion. Many eminent critics, among them Alford, explain the incident from natural causes. The Magi were a well-known body of religious astronomers, or perhaps astrologers, resident either in Chaldæa or in Persia. The country from which they came is not stated; there is merely the indefinite expression: "Behold wise men came from the East." The Fathers, in general, have fixed on Arabia. Whether the star was a miraculous or a natural phenomenon is a matter of dispute. An extraordinary astronomical fact, regarded by astronomers as demonstrated, is mentioned by Kepler. About the period of the birth of our Lord there was a remarkable conjunction of the planets Jupiter and Saturn in the constellation Pisces, which occurred three times in the year of Rome 747 , or B.c. 7 , on May 29 , September 29, and December 5. This fact was carefully examined by the Rev. Charles Pritchard, the honorary secretary of the Royal Astronomical Society, and its accuracy was vouched by him. At the same time, it must be observed that the planets were never so closely conjoined

1 See Guericke, Isagogik, pp. 240, 241.

2 So Meyer: "The unity of the Greek style and expression is to be explained from the unity of the translator."

3 Norton's Genuineness of the Gospels, vol. i. p. 208. 
as to appear one large star; there was always a space equal to the diameter of the moon between them. ${ }^{1}$ But to stargazers as the Magi, and especially to astrologers, it must have proved a striking phenomenon. It has accordingly been supposed that this celestial phenomenon constituted the star which appeared to the Magi, and that its occurrence three times seemed to guide their steps from the East to Bethlehem.. " "Supposing," observes Dean Alford, "the Magi to have seen the first of these conjunctions, they saw it actually 'in the East'; for on the 29th of May it wonld rise three and a half hours before sunrise. If they then took their journey, and arrived at Jerusalem in a little more than five months" (the September conjunction would occur); "if they performed the route from Jerusalem to Bethlehem, the December conjunction would be before them in the direction of Bethlehem. These circumstances would seem to form a remarkable coincidence with the history in our text." ${ }^{3}$ The coincidence is certainly very remarkable, but it is doubtful whether this conjunction of these planets is to be identified with the star of Bethlehem. For one thing, we would require to put back the birth of our Lord seven years, to B.c. 7 . This, however, is no insuperable objection, as it is now generally admitted that there is an error in our Christian era, and that our Lord's birth is antedated by several years. Still, in all probability, the star was a supernatural phenomenon, as it is apparently so described in the narrative-some meteor, divinely formed for the purpose, which, by its movements, guided the wise men to the infant Messiah. The supreme dignity of our Lord, as the long promised Messiah, the Son of

1 See art. "Stern der Weisen" in Winer's Biblisches Realwörterbuch; art. "Star of the Wise Men," by Rev. Charles Pritchart, in Smith's I)ictionary of the Bible; Alford's Greck Testument on Matt. ii. 2 ; Kepler, Je Jesu Christi vero anno natalitio; Wieseler's Symopsis of the Four Gospels, M1. $86 \mathrm{ff}$., Eng. trans; Ellicott's Lectures on the Life of our Lorel, 1. 72, note 2.

${ }^{2}$ A distinguisher Jewish rabi, Abarbanel, states that there was a trarlition that the conjumetion of Jupiter and Siturn in the sign Pisces was most important for the Jewish nation, that it tonk place at the hirth of Moses, and that it will ocenr at the arlvent of the Mesciall. Elorard's Crospel History, 1. 178; M'Clellatn, On the Gosmet., 1. 400.

${ }^{3}$ Alford's Greel Testement, note on Matt. ii. 1, 2. 
God, and the Redeemer of the human race, were reasons sufficient for the occurrence of extraordinary phenomena at His birth.

The massacre of the infants of Bethlehem is regarded as another incident which casts a doubt on the truth of the narrative (Matt. ii. 16). There is no reference to such an occurrence in the contemporary history of Josephus. The barbarities of Herod are there minutely described, but this barbarous and apparently unnecessary slaughter of helpless infants is not even hinted at.

The answer to this objection is obvious. Such an act of barbarity is entirely in conformity with the character of Herod. He waded through blood to his throne, and his whole reign was steeped in blood. He put to death his wife, Mariamne, and his three sons, Alexander, Aristobulus, and Antipater. Immediately before his death, he cansed the principal men among the Jews to be arrested and collected in the Hippodrome at Jericho, and gave orders that they should be put to death immediately at his decease, so that there should be a general lamentation at his death. ${ }^{1}$ Nor is the massacre of the infants to be exaggeratec. Bethlehem was a small village, and the infants slain, from two years old and under, would be few in number, - a trifling incident compared with the other enormities of Herod, who rivalled Nero in his cruelties, though on a smaller scale. Josephus might easily pass over such an act of cruelty in recording atrocities of a much more stupendous nature.

But the chicf objection is the apparent discrepancy between this narrative and the narrative of our Lord's birth as recorded in the Gospel of Luke. We have already had occasion to allude to the striking difference between these two narratives in proof of the statement that the Gospels of Matthew and Luke must have been written independently of each other; it is here referred to for another reason, because it has been maintained by those who deny the genuineness of Matthew's narrative that the difference is so great as to amount to a contradiction, so that both accounts cannot

${ }^{1}$ For a striking statement of the cruelties of Herod the Great, see Neander's Life of Christ, p. 30, Bohn's edition. 
possibly be true. ${ }^{1}$ For example, it is aftirmed that the residence of Joseph is differently stated by these two evangelists. Aceording to Luke, Joseph and Mary dwelt in Nazareth. "Joseph," we read, "went up from Galilee ont of the eity of Nizareth to the eity of David, which is called Bethlehem" (Luke ii. 16). He remained there until the rites according to the law of Moses were completed, and then he and Mary returned to Nazareth, which is expressly ealled their own

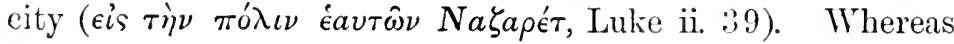
Matthew, without mentioning any previous resilence in Nazareth, relates that Jesus was born in Bethlehem of Judiea; that Joseph and Mary left that city in consequence of a divine warning and fled to Egypt, where they remained until the death of Herod; that after the death of that monarch they returned, but, in consequence of another divine premonition, did not resume their residence in Bethlehem, but withdrew into the parts of Galilee, and came and dwelt in a city called Nazareth (Matt. ii. 2:). Now, certainly, the natural impression from this narrative is that Bethlehem and not Nazareth was the residence of Joseph. This, however, is not asserted by Matthew, and the fact that Joseph came and dwelt in Nazareth is in itself a presumption that he had some previons comnection with that town.

The difference in the incidents recorded by the two evangelists is certainly remarkable, but they are not so much at variance as to create a distinet diserepancy. We have only to sulpuse, what is in itself probable, that Joseph and Mary remained a full year in Bethlehem, and that the visit of the wise men did not follow direetly after the visit of the shepherds. The Matgi found Jesus and His mother, not in

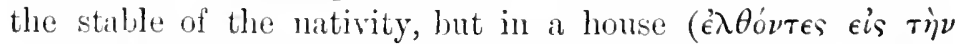
oikiay, Matt. ii. 11); and the age of the infints who were slaughtered was from two years old and under, according to the time which Herod hat earefully learned of the wise men (Matt. ii. 16).

The possible chromologieal orler of erents, which is that given in its general features by Tiatian in the Diatessaron, is

Isw Heyer, in loen, and sihleiermacher's St. Luke, trinslated by Biwlu, 'Thirlwall, 1'] $44 \mathrm{tr}$. 
as follows: Jesus, according to both Matthew and Luke, is born in Bethlehem of Judiea. According to Luke, He was born in a stable, and on the evening of the day of His birth He was visited by the shepherds. Soon after, Joseph with Mary and the child would remove to a house. Forty days after, according to the provisions of the law of Moses, the presentation in the temple of Jerusalem took place, where the child was recognised by Simeon and the prophetess Anna. From Jerusalem they returned to Bethlehem, perhaps with the intention of taking up their permanent residence there, as the city of David so hallowed in their view by what had occurred. Probably about a year after this the visit of the Magi and the appearance of the star occurred. Then, warned by God of the danger which threatened the child from the jealousy of Herod, they fled into Egypt, where they remained until his death, probably for a very short period. During their absence the massacre of the children of Bethlehem occurred. On hearing of the death of Herod, Joseph and Mary returned to Judæa, possibly to resume their residence in Bethlehem; but, in consequence of another divine warning, they returned to Nazareth, their former abode. By such a method any apparent discrepancy is obviated; at least it is shown that there does not exist any antagonism between the two narratives. We have only to suppose that Luke omits in his narrative the events which occurred during the temporary residence in Bethlehem. The return to Nazareth which he mentions (Luke ii. 39) is the same which Matthew mentions as taking place on their coming back from Egypt (Matt. ii. 23). ${ }^{1}$

2. Another passage, which has been and is still disputed, is the doxology attached to the Lord's Prayer" "For Thine is the kingdom, and the power, and the glory, for ever. Amen" (Matt. vi. 13).

The argument for the omission or retention of these words rests entirely on external evidence: there is nothing in the words themselves which can be adduced as an argument either for or against their insertion. The argument in fivour of the genuineness of this doxology is that it is found

${ }^{1}$ See Wieseler's Synopsis of the Four Gospels, 1. 136, chap. iii. Succession of events in the history of our Lord's childhood. 
in several important uncial MSS. ( $E, G, K)$; in all the cursive MSS. except five; in all the Syriac versions; in the Codex Brixianus $(f)$, an important manuscript of the Old Latin, in the Ethiopic and Armenian versions, and in the two Egyptian versions, the Sahidic and the Coptic. It is found in Tatian's Diatessaron, and in the Didaché, though only in part, $\dot{\eta} \beta a \sigma \iota \lambda \epsilon^{\prime} a$ being omitted. ${ }^{1}$ It is quoted by Chrysostom and subsequent Fathers. The argument against its insertion is that it is not contained in the principal uncial MSS., the Sinaitic, the Vatican, and the Codex Bezæ; the Alexandrian and the Codex Ephremi are here defective. It is wanting in the MSS. of the Old Latin, with the exception of the Codex Brixianus, and in the Vulgate. It is not quoted by any of the Greek Fathers until Chrysostom, and is omitted by the great Latin Fathers-Tertullian, Cyprian, Augustine, and Jerome. It occurs with several variations, as: "Thine is the kingdom, and the power, and the glory of the Father, and of the Son, and of the Holy Ghost." It is omitted in the form of the Lord's Prayer as given in the Gospel of Luke.2

The words are rejected by the vast majority of the critical editions of the New Testament, by the Complutensian editors, Erasmus, Bengel, Mill, Wetstein, Griesbach, Scholz, Lachmann, Tischendorf, Tregelles, Westcott and Hort. Scrivener is almost the only one who expresses any dubiety. "It is right to say," he observes, "that I can no longer regard this cloxology as certainly an integral part of St. Matthew's Gospel; but I am not yet absolutely convinced of its spuriousness." 3 The words are regarded as spurious by Grotius, Luther, Melanchthon, De Wette, Tholuck, Meyer, Olshausen, Alford, Davidson, Wordsworth, M'Clellan, Morison,

1 Didaché, ch. viii.

${ }^{2}$ For disctissions on the genuineness of the doxology, see Alford's Greek Testement, in loco; Davidson's Biblical Criticism, vol. ii. 11. 427-430; Scrivener, Introluction to the Criticism of the N.T. vol. ii. PI. 3223-328, 4th ed.; Cook, lierised Version of the First Three Gospels, pp. 5i If.; II'Clellan's New Testament, 1. 647; Westcott and Hort, New Testement in Greek: Notes on

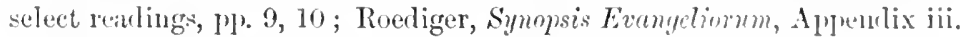
I. 229.

3 Sicrivener's Introduction to the Criticism of the N.T. vol. ii. 323, 4th exlition. 
and the most noted commentators. It is expunged in the Revised edition without any marginal note expressive of hesitation. ${ }^{1}$ "There can be little doubt," observes Dr. Hort, "that the doxology originated in liturgical use in Syria, and was thence adopted into the Greek and Syriac Syrian texts of the N.T. It was probably derived ultimately from 1 Chron. xxix. 11 (Heb.), but, it may be, throngh the medium of some contemporary Jewish usage; the people's response to the prayers in the temple is said to have been: "Blessed be the name of the glory of His kingdom for ever and ever." "2

\section{The Date of the Gospel.}

The time when the Gospel of Matthew was written is still a point of great dubiety. There is much diversity in the statement of the Fathers. Irenæus places it after A.D. 60 ; Eusebius, about A.D. 44, when the apostles were dispersed; Theophylact, at A.D. 41 ; and Nicephorus, at A.D. 48, fifteen years after the ascension. Different years, between A.D. 37 and A.D. 100, have been assigned by critics. ${ }^{3}$ The question may be put in this form, Was the date of this Gospel before or after A.D. 60 ?

The early date, before A.D. 60, has been adopted by Townson, Michaelis, Roberts, and Davidson (1st edition of his Introduction). Those who fix upon this date have the support of Eusebins, who says: "Of all the disciples (apostles) of the Lord, only Matthew and John have left us written memorials; and they, tradition says, were led to write only under the pressure of necessity. For Matthew, who had at first preached to the Hebrews, when he was about to go to other peoples, committed his Gospel to writing in his native tongue, and thus compensated those whom he was obliged to

1 We, however, think that there should have been a marginal note stating that the passage is not altogether devoid of support.

${ }^{2}$ Westcott and Hort's Greck Testoment: Notes on select readings, p. 9.

3 The Tuibingen school assign a much later date to Matthew's Gospel : Pfleiderer supposes that it was written about the middle of the second century. Dr. Davidson, in the last edition of his Introduction, says: "The Gospel may be dated about 105 A.D." vol. i. p. 370. 
leave for the loss of his presence." 1 Aceording to this statement, whilst the apostles remained in Judxa, there was an oral communieation of the Gospel; the aetions and the diseourses of Christ formed the subject of their preaching, and of the instruetions given to the disciples; the want of a written Gospel was not then felt; but when they had to leave Judiea and go to other nations, the loss of their oral eommunications had to be supplied by some written documents; and, according to Eusebius, this was the occasion of Matthew's writing his Gospel. It is difficult to determine the date of the departure of the apostles from Judiea, but it could not have been long after the aseension. At the council of Jerusalem (A.I. 51) there were only present Peter, John, and James the Lord's brother; and on a previous occasion (A.D. 40), on his visit to Jerusalem, Paul saw none of the apostles save Peter and James the Lord's brother (Gal. i. 18, 19). The probability is that the persecution by Herod Agrippa (A.D. 4t) drove the apostles from Jerusalem. According to an ancient tradition, the apostles were commanded by our Lord to remain for twelve years in Jerusalem. Thus Apollonius, who wrote in the second century, states that it was handed down by tradition, that our Saviour commanded His disciples not to depart from Jerusalem for twelve years. ${ }^{2}$ And the same tradition is recorded in an apocryphal work, quoted by Clemens Alexandrinus, entitled, The I'recthing of P'cter. "The Lord said to His apostles, 'If anyone therefore of Israel repent, and through My name Je willing to believe in God, his sins shall be forgiven him. After twelve years, go ye out into the world, lest any saly, We have not heird." "3 This period coincides with the persecution by Ilerod Agrippa. As, however, Peter, John, and Janes were present at the council of Jerusalem, A.D. 51, the final dispersion of the apostles must have taken place some years later. Accorling to this view, we fix the date of Matthew's Gospel hetween A.D. 55-60.

There are several presumptive reasons in favour of this date. So long as the apostles remained in Jerusilem, and

${ }^{3}$ Euscubins, Mist. Eicl. iii. 24.

2 Ihill. v. 18.

${ }^{3}$ Clemens Alexanrlrimus, Strom. vi. 5. 
the disciples were privileged with their instructions, the oral Gospel was suffieient. But when the apostles left, and the Chureh was umprovided with qualified teachers, - with those who were personally cognisant of the life of Jesus, and were the eye-rvitnesses of His actions and the hearers of His diseourses, - a written Gospel was indispensable. And especially would this be the case when we consider that in a short time Christianity overstepped the boundaries of Judxa, the Gospel was diffused throughout the adjacent countries, the Gentiles were admitted into the Church of Christ, and before A.D. 50 Paul had founded Churehes in Phœnicia, Syria, Cyprus, and Pisidlia. The apostles could no longer supply the wants of the times: it was essential that the actions and discourses of Christ should be committed to writing. We cannot suppose that no Gospel was written until thirty years after the death of Christ, and that the life of Christ, His words and aetions, were left to the uneertainties of tradition. Early Gospel fragments would be dispersed throughout the Churches, - probably different in different Churches and localities, - and many of them would be collected and authentieated by apostolie men. And we know, as a matter of fact, that anthoritative Gospels were at an early period recognised by the Chureh.

The later date, after A.I. 60, appears not so probable; but nevertheless it is the one that has been adopted by the majority of modern crities. It is the opinion of Eichhorm, Credner, Hug, Michaelis, Lardner, Bertholdt, Bleek, Davidson (3rd ed.), and Weiss. Those who fix upon it have the support of Irenæus. "Matthew," observes that Father, "issued a written Gospel among the Hebrews in their own dialeet while Peter and Paul were preaching the gospel at Rome, and laying the foundations of the Chureh." 1 As Paul did not reach Rome until A.D. 61, the date here assigned must have been after A.D. 60 . It is argued that there are in the Gospel of Matthew itself intimations of a late date. Thus we read that the field purchased by the treason money of - Judas is called the field of blood unto this day (Matt. xxvii. 8 ) ; that the report of the soldiers about the stealing of the ${ }^{1}$ Irenæus, $A d v$. Herr. iii. 1. 1 ; Eusebius, Hist. Eccl. v. 8. 
body of Jesus was spread abroad anong the Jews and continued until this day (Matt. xxviii. 15),-a phrase whieh implies that there must have been an interval between the ocenrence of these events and the writing of the Gospel. 3ut, so far as we can sce, an interval of fifteen years is sufficient to answer the requirement.

Another argument on which some crities gromm the later date of Matthew's Gospel, is the mention of Zacharial, son of Barachiah, who is said to have been slain between the sanctuary and the altar (Matt. xxiii. 35). Hng, Credner, Eichhorn, and apparently Weiss, ${ }^{1}$ suppose that this Zachariah is Zachariah the son of Baruch, whose murder at the commencement of the Jewish war by the Idumeans in the temple is mentioned by Josephus; ${ }^{2}$ and hence they argue that the Gospel was not written until after this event; that it was an assertion put into the mouth of our Lord by the writer of this Gospel. Hug attempts to escape the objection drawn from this anachronism by supposing that our Lord spoke of the death of Zachariah in a prophetic spirit, although

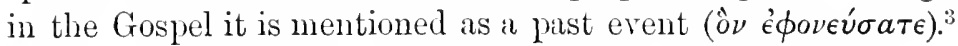
But the supposition is wholly fanciful. The Zachariah of Josephus is the son of Baruch, not of Barachiah. There is indeed a difficulty in identifying the person of whom our Lord speaks with any prophet mentioned in the Old Testament; but the common opinion is probably correct, that the allusion is to Zachariah the son of Jehoiada, who was murdered in the court of the temple by order of King Joash ${ }^{4}$ (2 Chron. xxiv. 20-22).

The statement of Irenceus, which has given rise to this opinion of the later date, is of doubtful credibility. He speaks of Matthew's Gospel being written when l'eter and

$1 \mathrm{Ti} \cdot \mathrm{s}$, Einleituny in des N.T. $\$ 47$, trans. vol. ii. 1. 28.8.

2 Josephus, liell. Jual. iv. 5. 4.

3 Hus's Introduction to the N.T. vol. ii. 1). 12, Engr. trims.

"The difference of name, Jehoiarla instend of Binlahiall, is a ditlienly.

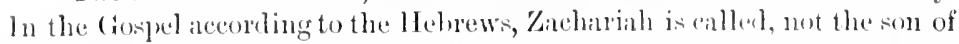

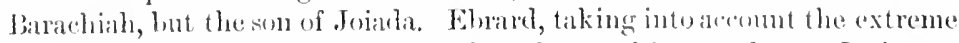
age of . Iholiata, supposes that Zacharial was his grandsom. Is it not posille that it might have licen the prophet "/echariah who is called the son of Liarichialı? (\%ech. i. 1). 
Panl were in Rome preaching and founding the Church. ${ }^{1}$ But the Roman Church was not founded by Peter and Panl: it was in existence long before either Peter or Paul arrived in that city. Paul, when he came to Rome, found Christians already there, and had several years before written an Epistle to them. It is very doubtful whether Paul and Peter were ever in Rome together; indeed it is a question whether Rome was ever visited by the Apostle Peter. His first Epistle is written from Babylon (1 Pet. v. 13), and the fact of his residence in Rome greatly depends mpon the answer to the question, whether by Babylon is meant the renowned city on the Euphrates, or whether it is a metaphorical name for Riome. $^{2}$

Some critics endeavour to reconcile these two dates-the earlier and the later-by the supposition that two editions of Matthew's Gospel were written, the one in Aramaic and the other in Greek, and that these editions were written at different times. The Aramaic Gospel, being at first the most requisite, was written earliest, about A.D. 44, on the departure of the apostle from Judæa. Afterwards, when the disciples became more numerous, and were composed for the most part of Greeks, it became necessary that it should be translated into Greek; and this was done, either by Matthew himself or some other person, about A.D. 60. "I can," says Michaelis, "see no impropriety in believing that both the early and the later date, assigned to St. Matthew's Gospel, are consistent with truth; that it was originally written in Hebrew in the beginning of the year 41, before Herod Agrippa was appointed king of Judra, but that the Greek translation of it was not made until the year 61 or later." 3 That there were two such editions, an Aramaic and a Greek Gospel, is a supposition perfectly admissible, indeed has presumptive evidence in its favour.

The place of composition was most probably Jerusalem

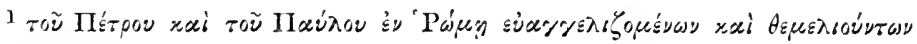

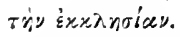

2 See Gloag's Introduction to the Catholic Epistles, 1'p. 144-161: Dissertation, "Peter's residence in Rome."

3 Marsh's Michuelis, vol. iv. 1. 112, 2nd ed. 
or some part of Judiea. Everything in the Gospel points to this: the references to the customs of the Jews, the mention of localities, the Hebrew garb of the narrative, are all reconcilable with the supposition that it was written in Palestine. In Judæa also Matthew would find his authorities and the sources of his marrative.

\section{Contents of the Gospel.}

It is unnecessary to give a table of the contents of the Gospel of Natthew; this is given in every commentary, and may be easily gathered from a survey of the Gospel. At the same time, the Gospel can only be studied in connection with the other Gospels in the form of a harmony, as they mutually supplement each other.

The Gospel of Matthew may be conveniently divided into six unequal parts.

1. The birth of Christ (i., ii.). This part contains the genealogy of our Lord and the narrative of His birth.

2. The preparation for His ministry (iii--iv. 11). This part includes the ministry of John the Baptist, the baptism of Jesus, the descent of the Spirit upon Him, His inanguration as the Son of Cod, and the temptation in the wilderness.

3. The Galilean ministry (iv. 12-xviii. 35). This part, which forms the main boly of the Gospel, contains the call of the apostles and the first missionary journey in Cralilee, the Sermon on the Monnt, a narrative of several miracles performed by Christ, instructions given to the apostles when sending them forth to preach the gospel, the deputation from the Baptist, our Lord's dispute with the Pharisees, a series of miracles, the fate of the Baptist, the twofold feerling of the multitude, the confession of the Messiahship of . Jesus by His disciples, the transfiguration, various instructions inparted to the disciples.

4. The jomney to Jerusalem and residence there (xix. 1xxv. 46). 'This part contains His departure from Galilee, I Iis gradual progress to. Terusalem and II is trimuphal entrance, the denunciations pronomneed on the seriles and Pharisees, 
the prediction of the destruction of Jerusalem, and a series of parables delivered toward the close of His ministry.

5. The Passion (xxvi., xxvii.). This part includes the anointing of our Lord at Bethany, the institution of the Supper, the agony in Gethsemane, the examination of Jesus before Caiaphas, the trial before Pilate, the crucifixion, death, and burial.

6. The Resurrection (xxviii.).

Perhaps the most characteristic portions of this Gospel are the Sermon on the Mount (v.-vii.), and the two series of parables on the nature of the kingdom of heaven, the one delivered about the middle of our Lord's ministry (xiii.), and the other toward its close (xxv.). 


\section{ISSERTA TION.}

\section{$\longrightarrow$ \\ QUOTATIONS FRON THE OLD TESTAMENT.}

The consideration of the quotations made by the writers of the New Testament from the Old Testament is a very wide subject, and can only be touched upon in this dissertation. It is complicated by the fact that there are two sources from which these quotations have been derived,-the original Hebrew and the Septuagint or Greek translation,- - and these often differ from each other. In general the difference is trivial, but sometimes it is important, and alters the sense. The subject has been carefully examined by the late Dr. Turpie in his book, entitled, The Old Testament in the New, a work of much learning and labour. He arrives at the following results. There are 275 undoubted quotations from the Old Testament by writers of the New. These are arranged under five divisions. 1. Those passages in which the Hebrew, the Septuagint, and the New Testament all agree, of which there are fifty-three. 2. Those in which the New Testament agrees with the Hebrew, hut differs from the Septuagint, of which there are ten. 3. Those in which the Hebrew and the Septuagint agree, but differ from the New Testament, of which there are seventy-six. 4. Those in which the New Testament agrees with the Septuagint, but differs from the Hebrew, of which there are thirty-seven. 5. Those in

1 "A contribution to Billical Criticism and Inter] retation. The quotations from the Old Testament in the New alasilied arording to their agreement with, or variation from, the original." London, 1868. This was followed hy a comprumion volume, entitler, The New Testement View of the Old. Iondon, 1872. 
which all three-the Hebrew, the Septuagint, and the New Testament-differ, of which there are ninety-nine. To those have to be added three passages (John vii. 38, 42; Eph. v. 14) which are only doubtful quotations. ${ }^{1}$

The Gospel of Matthew has, in proportion to its length, a greater number of quotations from the Old Testament than any other New Testament writing, with the exception of the Epistle to the Romans. The reason is obvious, because the special design of this Gospel was to prove the Messiahship of Jesus, and for this purpose the evangelist had to draw his proofs from the Old Testament. The number of quotations has been variously estimated. Dr. Davidson, who includes a number of coincidences which are not strictly citations, gives the number at sixty-one ${ }^{2}$ whilst Dr. Turpie, restricting himself to undoubted citations, reduces it to forty-one. Taking Dr. Turpie's book as guide, though not strictly following it, we give the list of quotations in Matthew's Gospel with the following distinctive marks: $a$, denoting those which agree both with the Hebrew and the Septuagint: $\beta$, those which agree with the Hebrew, but differ from the Septuagint; $\gamma$, those which agree with the Septuagint, but differ from the Hebrew; and $\delta$, those which differ both from the Hebrew and the Septuagint.

N.T.

\begin{tabular}{|c|c|c|}
\hline \multicolumn{3}{|c|}{ Matt. i. 23 . } \\
\hline & $"$ & ii. 6 . \\
\hline & " & ii. 15 . \\
\hline & $"$ & ii. 18 \\
\hline & , & ii. 23 \\
\hline & $"$ & iii. 3 \\
\hline & $"$ & iv. 4 . \\
\hline & " & iv. 6 . \\
\hline & ", & iv. 7 . \\
\hline & $"$ & iv. 10 \\
\hline & $"$ & iv. 15,16 \\
\hline
\end{tabular}

O.T.

Isa. vii. 14.

Nic. v. 1,2 .

Hos. xi. 1.

Jer. xxxi. 15 .

Isa. xi. 1 ?

Isa. xl. 3 .

Deut. viii. 3.

Ps. xci. 11, 12.

Deut. vi. 16.

Deut. vi. 13.

Isa. ix. 1, 2.

1 Turpie's Old Testament in the New, p. 267. See also Farrar's Life of Christ, vol. ii. pp. $483 \mathrm{f}$.

2 Davidson's Introduction to the Study of the N.T. 3rd ed. vol. i. pp. 375, 376. See also Davidson's Hermeneutics, pp. $334 \mathrm{ff}$. 
X.T.

$\delta$ Matt. viii 17

8

$\gamma$

$\delta$

8

8

$\delta$

$a$

$\delta$

$\delta$

$a$

a

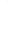

$\delta$

$$
\delta
$$

\begin{tabular}{|c|c|c|}
\hline$\delta$ & , & xxii. 32 \\
\hline$\delta$ & , & xxii. 37 \\
\hline$a$ & , & xxii. 39 \\
\hline$a$ & , & xxii. 44 \\
\hline & , & xxvi. 31 \\
\hline$\delta$ & $"$ & xxvii. 9, 10 \\
\hline & , & xxrii. 35 \\
\hline$\beta$ & ," & xxvii. 46 \\
\hline
\end{tabular}

\section{O.T.}

Isa. liii. 4.

Hos. vi. 6.

Mal. iii. 1.

Hos. vi. 6 .

Isa. xlii. 1-4.

Isa. vi. 9, 10.

Ps. Ixxriii. 2.

lix. xx. 12 .

1sa. xxix. 13.

Deut. xix. 15.

Gen. i. 27.

Ge1l. ii. 24.

Ex. xx. 12-16.

Zech. ix. 9.

Isa. lvi. 7 .

Ps. viii. 2.

Ps. cxviii. 22, 23.

Deut. xxv.

Ex. iii. 6.

Deut. vi. 5.

Lev, xix. 18.

P's. ex. 1.

Zech. xiii. 7 .

Zech. xi. 13.

Ps. xxii. 18. ${ }^{1}$

Ps. xxii. 1, 2.

From this list of quotations it appears that there are six in which the Hebrew, Septuagint, and New Testament agree (iv. 7 , xix. 18 , xxi. 16,42 , xxii. 39,44 ); two which are taken from the Helnew original, lut which differ materially from the Septnagint (ii. 15, xxvii. 46); and one which agrees verbation with the Septnarint and differs from the Hebrew (xiii. 14, 15). ${ }^{2}$ By far the langer number, anomnting to twenty-seven, liffer both from the IJelnew and the septuagint. These differences are, howerer, in general immaterial. They consist in a different arrangenent of the words, in the

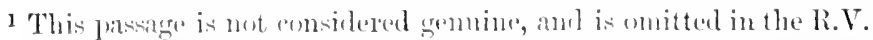

2 In this eliss atso ir. 7 and xxi. 42 are placed ly 1)r. 'l'urpie, but the difference from the Hetrew is very slight. 
omission or insertion of connecting particles, and in the change of tenses; the meaning remains in general unaltered. It would appear that the New Testament writers frequently quoted from memory, without examining either the Hebrew original or the Septuagint. In the same manner the early Fathers quoted from the Scriptures both of the Old and New Testaments, as is seen in the numerous quotations in the writings of Justin Martyr and Clemens Alexandrinus, in which there are many deviations from Scripture. The same is the case in the present day: theologians often do not quote accurately; they give the sense of a passage, without using the precise words.

Different opinions have been adopted regarding the quotations from the old Testament in general. Some hold that the New Testament writers quoted always from the Hebrew, giving their own free translation; others, that they made use of the Septuagint, quoting from it in a free and general manner; and others, that they adhered uniformly to neither, but frequently quoted from memory, and made a free use of their sources. ${ }^{1}$ Bleek asserts, with special reference to the Gospel of Matthew, that in the citations which occur in the body of the narrative the Septuagint was used, whilst in those which the evangelist introduces in his own reflections, the Hebrew original is employed. But this statement is not borme out by fact, as may be seen by an examination of the passages. It would rather appear that the Septuagint lies at the root of most of the quotations, even of those which differ from it.

The extent to which the Septuagint was used in the days of our Lord is a matter of dispute. Some affirm that it had superseded the Hebrew original, and was used in the Jewish synagognes. ${ }^{2}$ Hebrew was then a dead

1 Davidson's Introduction to the Study of the N.T. 3rd ed. vol. i. pp. 375, 376; Speaker's Commentary, "Introduction to the Gospels," by Archbishop Thomson, p. xxviii ; Westcott's Introduction to the Study of the Gospels, Appendix A, "On the Quotations in the Gospels"; Bleek's Introduction to the N.T. vol. i. p. 295 ; Davidson's Hermeneutics, pp. 334 516.

2 "Every available source of evidence," observes Professor Roberts, "which is worth anything, points to the conchusion that the Greek transla- 
language, and was not understood by ordinary Jews, and, so far as we know, there was no Aramaic translation. Besides, copies of the Hebrew Bible would be exceedingly expensive, whereas copies of the Septuagint would be more easily procured, owing to the abundance of Greek slave labour employed in transeription. Most probably in the synagogues the original Hebrew, being the saered language, would be used, even as in the present day; whilst Jews, for their own private reading and edification, would possess copies of the Septuagint, owing to its comparative inexpensiveness. When our Lord appeared in the synagogue of Nazareth, there was delivered to Him the roll of the prophet Isaiah, most probably in the original Hebrew. The passage which $\mathrm{He}$ read, as quoted in the New Testament: "The Spirit of the Lord is upon Me, because He anointed $\mathrm{Me}$ to preach good tidings to the poor; He hath sent Me to proclaim release to the captives, and recovering of sight to the blind, to set at liberty them that are bruised, to proclaim the acceptable year of the Lord"1 (Luke iv. 18, 19), differs both from the Hebrew and the Septuagint. The difference is immaterial, but we cannot say from which source the quotation is made; so that no inference can be drawn from it as to the comparative use of the Hebrew or the Septuagint in the Jewish synagogues. On the other hand, the quotations made by the New Testament writers are in general pervaded by the spirit of the Septuagint, whilst the Hebrew is very seldom literally translated. Dr. Turpie mentions only ten passages whieh agree with the Hebrew but differ from the Septuagint, ${ }^{2}$ and thirty-seven which agree with the Septuagint but differ from the Hebrew. All those far more numerous passages, amounting to 175 , which differ alike from the Hebrew and the Septuagint, in general approach more nearly to the Septuagint; so that there appears reason for l'rofessor Roberts' remark: tion of the Old Testament Scriptures was then regularly used in the symagrogues of Palestine," Greck, the Language of Christ und His A postles, 1. 453.

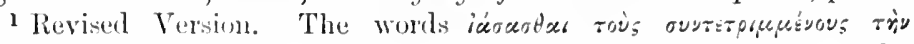
repoicas, "to heal the broken-heartel," are onittecl, as not found in the lest mannecriptis.

2 These passiges are Natt. ii. 15 , xxvii. 46 ; Mark ii. $29,30, x v .28,34$; Luke xxii. 37 ; 1 Cor. iii. 19 ; 2 Cor. viii. $15 ; 2$ Tim. ii. 19 ; Heh. v. 12. 
"In the vast majority of these quotations the Septuagint is either exactly followed, or the resemblance is so close as to be virtually identical." 1

There is little variation in the formulae of quotation used by Matthew. In general it is "iva $\pi \lambda \eta \rho \omega \theta \hat{\eta} \tau \grave{\rho} \dot{\rho} \eta \theta \dot{\epsilon} \nu$, "that it might be fulfilled which was spoken"; to which is

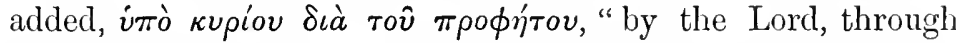

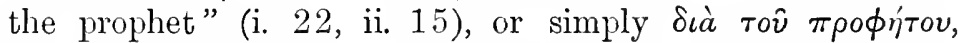
"through the prophet" (xiii. 35, xxi. 4), or $\delta i \dot{a} \tau \hat{\omega} \nu \pi \rho \circ \phi \eta$ -

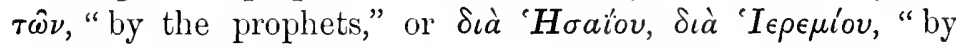
Isaiah," "by Jeremiah" (ii. 17, iv. 14, viii. 17, xii. 17 ,

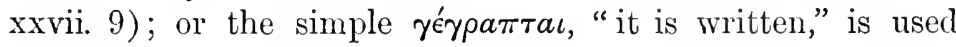
(iv. $4,6,7,10$, xi. 10 , xxi. 13 , xxvi. 31 ). This last form is generally employed by our Lord in His quotations from the Old Testament. In general the quotations are given as direct proofs, stating that the prophecies were fulfilled in the events recorded. Sometimes the comnection between the prediction and its fulfilment is not clearly discernible, and in these cases it has been supposed that the evangelist quotes the words of the prophet by way of accommodation or illustration. ${ }^{2}$ And sometimes words are given in the form of a citation, which are not to be found in these precise terms in the Old Testament, so that there is a difficulty in knowing to what prophecy the evangelist refers. ${ }^{3}$

In the Gospel of Matthew there are four quotations which in themselves are either of doubtful application or obscure in meaning.

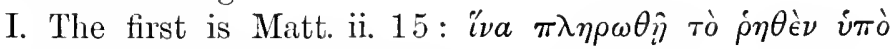

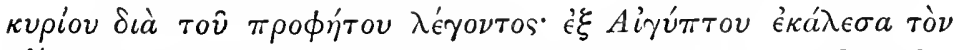
vió $\nu$ pov: "that it might be fulfilled which was spoken by the Lord through the prophet, saying, Out of Egypt did I call My Son."

The words are quoted with special reference to the flight of Mary and Joseph into Egypt, and are stated as a prediction of that event. The quotation is from Hos. xi. 1, and is taken from the Hebrew, with which it literally agrees. It differs from the Septuagint, which reads: "Out of Egypt

${ }^{1}$ Roberts' Greek, the Language of Christ, p. 135.

2 See Matt. ii. 15, 17, 18. 3 See Matt. ii. 23. 
did I call His children." I Some suppose that the lifference between the Hebrew and the Septuagint arose from the difference in the Hebrew vowel pointing; but it would rather appear that the Septnagint translators must have read instear of ?ב?? The allusion by the prophet Hosea was probably to the message of Moses to Pharaoh, being the only passage where Israel is called the son of God: "Thus saith the Lord, Israel is $\mathrm{My}$ son, My firstborn: and I have said unto thee, Let My son go, that he may serve Me" (Ex. iv. $22,23)$. The nation of Israel was God's adopted son, chosen from anong the nations of the world.

The words of the prophet are rather a historical statement than a prediction. They refer to a past transaction rather than to a future event. ${ }^{2}$ The deliverance of the Israelites from Egyptian bondage is evidently the event alluded to. Hence it is asked, How can this historical event, which refers to the nation of Israel, possibly be a prediction which has received its fulfilment in our Lord's sojourn in and return from the land of Egypt?

The solutions which have been given of this difficulty are manifold. Dr. Lindsay Alexander supposes that the passage is not a citation from the Old Testament, but one of the traditions of the elders handed down among the Jews, namely, that the Messiah should sojoum in Egypt. ${ }^{3}$ Others think that it is used by way of illustration, being a proverbial expression to denote deliverance from any impending danger. ${ }^{4}$ And others suppose that the words are spoken by way of accommodation: that as Israel was brought out of Egypt, so was the Messiah. ${ }^{5}$ But it seems more correct to regard it as a secondary or typical prophecy. ${ }^{6}$ Isriel was a type of Christ: he is called God's son, because the Messiall, God's trie Son, was to spring from lim. In God's dealings

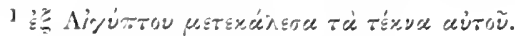

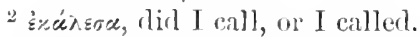

3 Connerion of the Ohl aml New Testaments, 1) 486.

4 Chandler's lefence of Christianity.

"Ifill's Divinity Letures, vol. i. J. 177.

"Matthew was a strict Hebrew, deeply imbued with Jewish notions, and saw in the incidents of Jewish history types and foreshinlowings of the (rospel. 
with Israel there is a typical reference to Christ: the Old Testament is but a prediction of the New: ${ }^{1}$ Christ is the Alpha and Omega of revelation. As all the sacrifices under the law were but types and emblems of the great sacrifice of Christ for sin, as the Levitical ritual prefigured the gospel dispensation, so the dealings of God with Israel had a spiritual reference, and were fulfilled in Christ. There are what have been termed secondary prophecies: predictions which are capable of a twofold application, which receive a primary but partial fulfilment in some person or event in Jewish history, and a secondary and more complete fulfilment in the Messiah: prophecies which, as Lord Bacon says, "are not fulfilled punctually at once, but have springing and germinating accomplishment." 2 Of course this infusion of a spiritual meaning into the Old Testament quotations must be made with the greatest cantion; and perhaps it is only justifiable when such a meaning is given by the inspired writers themselves.

II. Another quotation, which has given rise to much dispute, is from a prophecy of Jeremiah, which is said to have received its fulfilment in the slaughter of the infants

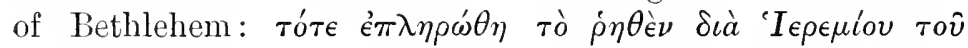

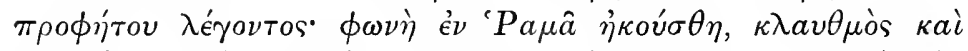

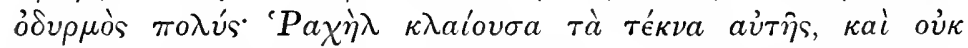

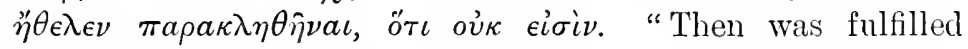
that which was spoken by Jeremiah the prophet, saying, A voice was heard in Ramah, weeping and great mourning, Rachel weeping for hel children: and she would not be comforted, because they are not" (Matt. ii. 17, 18).

This quotation, taken from Jer. xxxi. 15, differs from the Hebrew and the Septuagint; but the variations are of no importance. It is impossible to say from which of the two sources it has been taken. In all probability the words are quoted from memory; for there is no reason to assert, with certain critics, that they are taken from some other translation.

This is also one of those prophecies which admit of a

I "In the Old Testament, the New Testament lies concealed; in the New, the Old lies revealed." Augustine.

2 Bacon's Advancement of Learning. 
twofold application: a primary application to the event which occurred at the time when it was uttered, and a secondary application to the Messiah. In its primary sense it is not a prediction, but a historical statement. It has been referred to two events in the history of Israel. Some suppose that the reference is to the captivity of Israel by Shalmaneser, king of Assyria, when the Israelite captives were assembled at Ramah, where a number were put to death, and the rest led captive to Nineveh. But there is no mention of this fact in history. Others, with more probability, refer it to the assembling of the Jewish captives by Nebuzaradan, the general of Nebuchadnezzar, at Ramah, from which they were led bound in ehains to Babylon (Jer. xl. 1). It refers to the lamentation which was then made on account of the destruction and captivity of the nation. Rachel is by a bold personification represented as rising from her tomb, ${ }^{1}$ deploring with bitter wailing the great calamity which had befallen her offspring.

But whilst the words may have a primary application to the deportation of the Jewish captives from Ramah to Babylon (Jer. xl. 1), it received, according to the evangelist, a secondary application in the slaughter by Herod of the infants at Bethlehem. In its first application it is a historical statement; in its secondary application it is a prediction which has received its fulfilment. There are, undonbtedly, difficulties comnected with this view. Bethlehem was a town of Judrea, and the Jews were the direct offspring of Leah, not of liachel; on the other hand, the Benjanites, who were her descendants, were identified and bound 11 p with the Jews so as to become one nation, and thus the nation, as a whole, might well be considered as the descendants of liachel; and a certain allowance must be made for a bold poetical personification. Nor was Ramah the same as Ijethlehem, but a village a short distance from it; ${ }^{2}$ but the slanghter of the infints might have extemded to it, as we read that Herod slew all the children in Bethlehem, and in all the borders thereof (Matt. ii. 16).

1 Rachel was buried at Bethlehem, Gen. xxxy. 19.

${ }^{2}$ Only alout a mile distant. 
The question which here meets us is, How can that which refers to the captivity of the Jews by Nebuchadnezzar" be applied to the massacre of the children of Bethlehem? It has been shown that the Jews refer the prophecy to a much later period than the Babylonish captivity, and apply it to the disasters which befell their country under Vespasian and Hadrian. ${ }^{1}$ Josephus refers the prophecies of Jeremiah, not only to the destruction of Jerusalem by Nebuchadnezzar, but to the similar destruction by 'Titus. ${ }^{2}$ The Babylonish captivity was a striking incident in Jewish history, and made such a deep and lasting impression on the nation, as to be often referred to by them, and applied to other similar calamities. In this way, according to many commentators, it has been applied to the massacre of the children of Bethlehem. Thus Calvin says: "The prediction of Jeremiah having been accomplished at that time (the time when it was given), Matthew does not mean that it foretold what Herod would do, but that the coming of Christ occasioned a renewal of that mourning which had been experienced many centuries before by the tribe of Benjamin." 3 We consider this, then, as a secondary prophecy; and if we admit the inspiration of the evangelist, we must also admit the propriety of this application.

III. The next passage which claims attention is Matt.

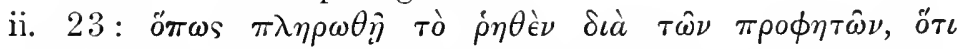
$N a \zeta \omega \rho a \hat{\imath} \circ \kappa^{\prime} \kappa \eta \theta \eta \dot{\sigma} \sigma \tau a \iota "$ : "that it might be fulfilled which was spoken by the prophets, that He should be called a Nazarene." 4

The reference here is to our Lord's residence in the town or village of Nazareth. This is said to be in accordance with the predictions of the prophets. But these words are to be found verbatim in no prophetical writing of the Old Testament. Nor cloes the evangelist refer to any particular

1 Marsh's Michaelis, vol. i. 117. 210, 211.

2 Josephus, Antiquities, x. 5. 1.

${ }^{3}$ Calvin's Commentary on the Gospels, in loco.

4 The Christians were at an early period called Nazarenes, as in the adrless of the orator Tertullus (Acts xxiv. 5). Nost probably in this instance the name is taken from the town of Nazareth. 
prophet or propheey; the word is in the plural ( $\pi \rho \circ \phi \eta \tau \hat{\omega} \nu)$, as if the statement referred to the general consensus of the prophets.

Chrysostom and Theoplyylact suppose that it is a lost propheey, either handed down by tradition, or eontained in some prophetical work which is no longer in existence. This view has been adopted by Bengel. ${ }^{1}$ Nor is there anything unreasonable in such a supposition. We learn from the Old Testament that many prophetic writings have perished: what remains may be a mere fragment of what was written. But it is improbable that Matthew would appeal to a lost prophecy, because in his time the canon of the old Testament had been fixed. Besiles, the worls $\delta i \dot{a} \tau \hat{\omega} \nu$ $\pi \rho \circ \phi \eta \hat{\omega} \nu$ would seem to have a wider reference than to a single propheey.

Another hypothesis is that the reference is to the lowly condition of the Messiah-that He was a despised person (Isa. liii. 3). The allusion was to the suffering character of the Messiah, in opposition to the view then prevalent among the Jews of an exalted Messiah. The whole provinee of Galilee was looked upon by the Jews in a depreciatory light. "Search, and see: that out of Galilee ariseth no prophet" (John vii. 52). And Nazareth was the despised town of a despised province: it appears to have become a proverbial expression: "Can any good thing come out of Nazareth?" (John i. 47). Henee it is supposed that when it is said, "He shall be called a Nazarene," that is, an inhabitant of Nazalreth, the reference is to His despised eondition. Such is the interpretation adopted by Michaelis, Kuinoel, Olshausen, Ebrard, Lange, Horne. lint it does not appear that the inhabitants of Nazareth as such were preeminently despised : the above-mentioned words of Nathanael may refer, not to the inhabitants, but to the obscurity and smallness of the town. Nazareth was a poor town: it is mentioned neither in the Old Testanent nor by Josephus. Can any good thing come out of Nazaretly? Ciun such an olseme town give rise to such an exalted person as the great Messiah?

${ }^{1}$ Bengel's linomon, in loco, trans. vol. i. p. 135. 
A third explanation refers the term Nazarene, not to the town of Nazareth, but to the order of the Nazarites. Thus it was said of Samson: "The child shall be a Nazarite unto

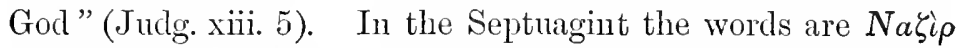
$\theta \epsilon o \hat{v}$, or, according to the reading of the Alexaudrian manuscript, Naלıaîo $\tau \hat{\omega} \theta \epsilon \hat{\omega}$. This is the view adopted by Tertullian, Jerome, Erasmus, Calvin, Beza, Grotius, Hilgenfeld, and others. Thus Calvin says: "Matthew does not derive Nazarene from Nazareth, as if this were its strict and proper etymology, but only makes an allusion (a play upon the word). The word devoted to God, derived from were men separated or consecrated to God. Thus, among the Jews, Samson and Samuel were Nazarites, and so also was John the Baptist. Those who hold this view refer this prophecy to the consecration of the Messiah. But our Lord was not a Nazarite in the strict sense of the term. He did not take upon Himself any Nazarite vows: His character and conduct were in this respect a contrast to the Nazarite John the Baptist. He was not an ascetic: "the Son of Man came eating and drinking" (Matt. xi. 19). He did not, like His forerumner, withdraw into the desert, and live the life of a recluse; but $\mathrm{He}$ mingled freely in human society, and thus could not be regarded as a true Nazarite. ${ }^{2}$

The majority of expositors see in the appellation Nazarene an allusion to prophets on the Messiah. Thus Isaiah says: "There shall come forth a shoot out of the stock of Jesse, and a Branch (ניצֵ) out of his roots shall bear fruit" (Isa. xi. 1). ${ }^{3}$ And a similar title is applied to the Messiah in other prophecies (Isa. iv. 2 ; Jer. xxiii. 5, xxxiii. 15 ; Zech. iii. 8, vi. 12), though in these prophecies the word employed is hypothesis is adopted by Gieseler, Bleek, De Wette, Meyer,

In loco.

2 The term Na Ywpaios is not identical with Nazarite.

3 In the Septuagint the word is $\ddot{\varkappa} \nu$ tos.

4 Thus Meyer observes: "In Isa. xi. 1 the Messiah, as the offspring of David, is called şבר shoot, with which in the representation of the evangelist this designation was identified." 
Hengstenberg, Davidson, Schaff, and Mansel. ${ }^{1}$ According to this view we have a direct reference to the prophecy of Isaiah. But it is to be observed that ֶ.s is only used by Isaiah, and the references to the Branch in the other prophecies cannot be employed, as it is an entirely different word that is used, which has no resemblance to Nazarene.

IV. The fourth example of a doubtful quotation is still more difficult, as it would seem that Matthew makes an erroneous quotation, giving the name of one prophet, whilst

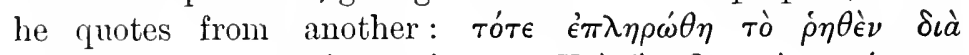

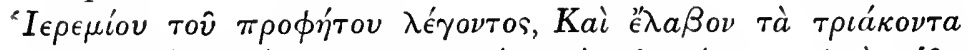

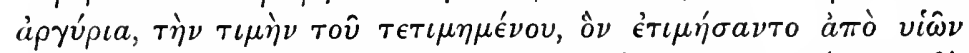
'I

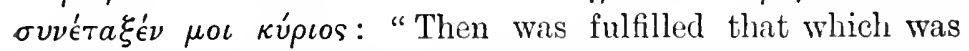
spoken by Jeremiah the prophet, saying, And they took ${ }^{2}$ the thirty pieces of silver, the price of Him that was priced, whom certain of the children of Israel did price: and they gave them for the potter's field, as the Lord appointed me" (Matt. xxvii. 9, 10).

The first thing to attend to is the criticism of the passage.

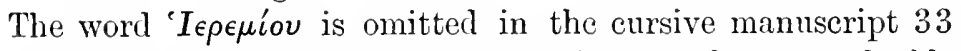
(the Codex Colbertinus), which is considered as the most valuable cursive manuscript extant, and in 157, a manuscript which belonged to the ducal library in Urbino, but now lodged in the Vatican. Zaxapiov is contained in the cursive manu-

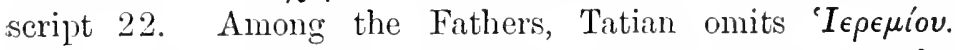
With regard to the Versions, we must take into account the statement of Augustine: "This ascription of the passage to Jeremiah is not contained in all the codices of the Gospels, but some of them state simply that it was spoken by the prophet." The codices to which he refers are those of the Old Latin : and in two important manuscripts of that Version - the Codex Vercellensis $(a)$ and the Codex Veronensis (b) - the word Jeremiah is wanting. It is also omitted in the

I Speuker's Commentury: the Gospel of Matthew, in luco. The first part of this commentary to ch. xxvi. was hy Dean Manse] ; the remander was ly Canon Cook.

2 "Ficeßon may be either the first person singular, I took, or the thind jerson plural, they took. 
Peshito Syriac and in the Persic Version. On the other hand, 'Ieperiov is the reading of all the uncial manuscripts, of the cursive manuscripts except those above mentioned, of all the Fathers who refer to the passage, as Origen, Jerome, Eusebius, and of all the Versions except the Peshito and the Persic. Thus, then, the undoubted preponderance of

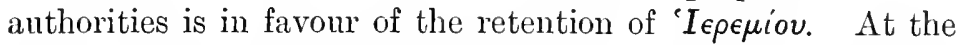
same time, if conjectural emendation is at all admissible, here would be a fit occasion for its application, and accordingly Origen and Eusebius conjecture that $Z$ a $\chi a$ piov was the original reading. But when we take into account the multiplicity of critical authorities and their variety, conjectural emendation in the criticism of the New Testament must be regarded as wholly inadmissible.

It is generally admitted that Matthew does not quote from the prophecy of Jeremiah, in which the words are not found, but from Zech. xi. 12, 13, where words somewhat similar occur. When, however, we compare the words in Matthew's Gospel with the Hebrew and the Septuagint, we find not only a variation from both, but such a material difference as does not usually occur in the quotations by the sacred writers from the Old Testament. The passage in the Hebrew is thus translated in the Revised Version: "And I said unto them, If ye think good, give me my hire; and if not, forbear. So they weighed for my hire thirty picces of silver. And the Lord said unto me, Cast it unto the potter: the goodly price that I was prized at of them. And I took the thirty pieces of silver, and cast them unto the potter in the house of the Lord." The passage in the Septuagint ${ }^{1}$ may be thus translated: "And I will say to them: If it be good in your eyes, give me my price, or refuse it. And they weighed for my price thirty pieces of silver. And the Lord said unto me, Put them into the furnace, and I will see whether it is

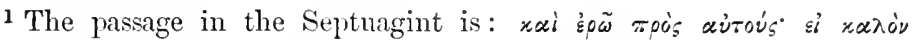

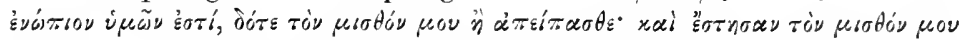

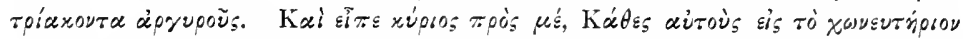

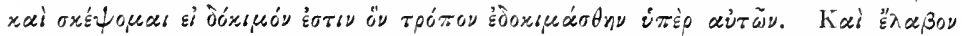

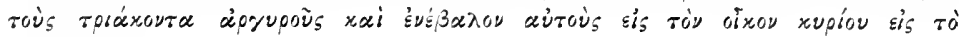

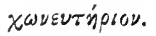


tested, as I have been tested for their sakes. So I took the thirty pieces of silver and cast them into the house of the Lord, into the furnace." The words in Matthew are different from both. Neither in the Hebrew nor in the Septuagint is there any mention of the field which was purehased by money. The clanse, "And they gave them for the potter's field, as the Lord appointed me," is found in neither of these sources. According to the Septuagint, the money is cast into the furnace for the purpose of being tested; according to the Hebrew, it is given to the potter ; and aceording to both, it is cast into the house of the Lord: none of which particulars is contained in the quotation as given by Matthew.-The explanations given of this diffieult passage are very numerous. We only mention the most plausible.

It is maintained that in the original the word Jeremiah is omitted and that Matthew wrote simply: "That which was spoken by the prophet." This is the explanation adopted by Bengel, Beza, Dr. Adam Clarke, and Dr. Doddridge. We have already considered the eritical reading of the passage, and have found that the overwhelming preponderance of evidence is in favour of the retention of Jeremiah, and that in the case of the New Testament conjectural emendation is inadmissible. We are consequently precluded from adopting this explanation.

It is supposed that there is in the passage no reference to the prophecy of Zechariah, but that it is a lost propheey of Jeremiah. The words, it is affirmed, are so different from those of Zechariah, as found, whether in the Hebrew or in the Septuagint, that they cammot be considered as a quotation from it. ${ }^{1}$ Jerome affirms that he had seen the passage in an apoeryphal book of Jeremiah written in Hebrew in the hands of the Nizarenes; ${ }^{2}$ and henee it is inferred that it is from

1 Thus Dean Burgon says: "Natthew is charged with a hat memory, becanse he ascribes to Jereny the prophet works which are said to be found in Zechariah. Strange that nen should be lexarl to differ abont a plain matter of fact! I lave nerer leeen alle to find these words in Zechariah yet."

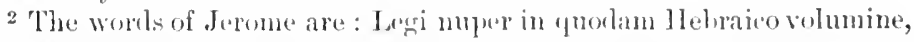

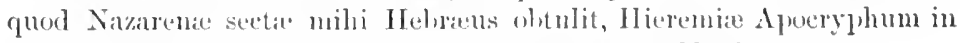
quo hae ad verbun seripta rejeri. Commentery on Muthex. 
this apocryphal book that Matthew quotes. Thus Michaelis remarks: "As far as I am able to judge, the only mode of solving the difficulty is to suppose that Matthew has borrowed the quotation from some fragment of Jeremiah which is no longer extant." 1 This is, however, an improbable solution, as the language of Jerome is indefinite, no such apocryphal Book of Jeremiah being elsewhere mentioned, and as similar words, though certainly not identical, are to be found in Zechariah. $^{2}$

A much more plausible solution is that the passage contained in the ninth, tenth, and eleventh chapters of Zechariah did not originally constitute a part of that prophetical book, but was written by Jeremiah, and inserted into the prophecy of Zechariah, just as the words of Agur are attached to the Proverbs of Solomon. This hypothesis was first suggested by Mede, and afterwards adopted with various modifications by Bishop, Kidder, Archbishop Newcome, Lowth, Whiston, Dr. Pye Smith, and Dr. Samuel Davidson in his Hermeneutics. So also Bertholdt, Michaelis, Rosenmüller, Knobel, Hitzig, Ewald, and Bleek, who, although they do not go the length of asserting that these chapters were written by Jeremiah, yet maintain that they were not the composition of Zechariah. The references in these chapters, it is said, relate, not to the time of Zechariah, but to the time of Jeremiah. Thus it is predicted that the pride of Assyria shall be brought down (Zech. x. 11), which was an accomplished fact in the time of Zechariah, but might form the subject of prediction in the time of Jeremiah. So also Gaza is threatened with destruction (Zech. ix. 5), which occurred under Nebuchadnezzar, in the time of Jeremiah, long before the days of Zechariah. There is also a prediction of the destruction of Jerusalem (Zech. xi. 1), which has been referred to the time of the Romans under Titus, but which would hardly have been

1 Marsh's Michaelis, vol. i. p. 242. Similarly M'Clellan: "Matthew cited a prophecy spoken by Jeremiah, not uritten in his book; and several spoken prophecies of Jeremiah, as dout,tless of other prophets, are not recorded." M'Clellan, New Testament, p. 606 ; Whitly, in loco.

2 Ensebius supposes that the Jews designedly removed the words from the prophecy of Jeremial.. See Sanday's Bampton Lectures, 1. 47. 
given in the time of Zechariah, when the Jews were to be eneouraged to rebuild their temple, and which is therefore more suitable as a prediction of the destruction of the city by Nebuchadnezzar in the time of Jeremiah. The predietion regarding the prosperity of Tyre and its subsequent destruetion (Zeeh. ix. 3, 4), though it might apply to the eapture of that eity by Alexander the Great, receives a better interpretation by referring it to its prosperity and subsequent destruetion by Nebuchadnezzar in the time of Jeremiah. ${ }^{1}$ But admitting the plausibility of this hypothesis, it cannot be the true solution. The prophecy of Zechariah was as complete in the time of Matthew as now: there were no divisions in it: and Matthew eould not suppose that what he quoted from that propheey were not the words of Zechariah, but of Jeremiah. The division of the propheey under different anthors, whether justifiable or not, is the result of a higher eriticism unknown in the days of the evangelist. ${ }^{2}$

It has been affirmed that this prediction is given under the name of Jeremiah, because the prophecy of Jeremiah was the first book of the prophets. The Old Testament reeeived a threefold division-the law, the prophets, and the psalms; and the first book of the division of the prophets is said to have been Jeremiah. The order in the time of Matthew was Jeremiah, Ezekiel, Istiah, the twelve minor prophets. The same is still the order in the Talmud and in the manuseripts of the French and German Jews. Thus it is supposed that Jeremiah gave his name to the division of the prophets, just as Datvid gave his name to the division of the P'salms, and Solomon to the Took of Proverbs. When, then, Matthew uses the name Jeremiah, he does not allude to the Book of .Jereniah, but to the volune of the prophets. "I do eonfidently assert," observes Dr. John Lightfoot, "that Mattlew wrote Jeremiah as we read it, and that it was very readily unlerstood and

1 This hypothesis is stated with great fuhness and sulported hy rery ingenious and pliasible arguments by Bishop Kithler, Jemonstration of the Messius, rol. ii. Pp. 196-217. See also Davintson's Itermeneutics, 1). $463-465$.

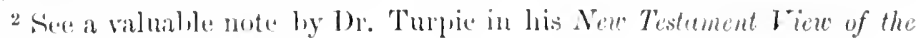
oh, [ए. 153-15\%. 
received by his countrymen," because Jeremiah of old had the first place among the prophets. "When, therefore, Matthew produced a text of Zechariah under the name of Jeremiah, he only cites the volume of the prophets under his name who stood first among the prophets." 1 This opinion has been adopted by Scrivener, Dr. David Brown, and Canon Cook in the Speaker's Bible. The evidence, however, is insufficient to prove that Jeremiah, and not Isaiah, stood at the head of the division " the prophets."

Some maintain that the statement in St. Matthew's Gospel is not a mistake, but a correct assertion, and that in reality the quotation is from Jeremiah and not from Zechariah. This is certainly a bold assertion, as only by the most forced interpretation, and by a defiance of all the laws of exegesis, can the passage be considered as a prophecy of Jeremiah. The passage in Jeremiah which has been fixed upon is xxxii. $6-9$, where Jeremiah is told to purchase from his uncle a field in Anathoth. The only resemblance here is the purchase of a field by the commandment of the Lord. This is supposed to be implied in the words, "and they gave them for the potter's field, as the Lord appointed me." But the resemblance is very faint. All the other parts of the prediction, the price, the thirty pieces of silver, the value set upon the Messiah, are considered as parenthetic clauses. Of conrse, if we are thus permitted to cut and carve the prophecy, we can make it agree with any prediction which has a few similar words, but we destroy its whole value as a prediction.

Somewhat similar to this last solution, or at least connected with it, is the supposition that the quotation is a conjoint prophecy from Zechariah and Jeremiah : that the prediction concerning the particular price, namely, the thirty pieces of silver, is taken from Zechariah; and that the other part of the prediction, concerning the buying of the field, is from Jeremiah. This opinion is adopted by Elsner, Hofmann, Lange, and Dr. Patrick Fairbairu. ${ }^{2}$ Elsner would supply a connecting particle: "That was fulfilled which was spoken by

1 Lightfoot's Horce Hebraice : Exercitations upon St. Matthew, vol. xi. p. 345, Pitman's edition.

${ }^{2}$ Fairbain's Hermeneutic Munual, 11. 440-448. 
Jeremiah and the prophet," an improbable form of expression. Still there is some plausibility in the above explanation. There are examples of such conjunct prophecies in the New Testament Mark i. 2, 3, although quoted as a prediction of Isaiah, is in reality taken both from Malachi and Isaiah (Mal. iii. 1 ; Isa. xl. 3); and if Matthew quoted from memory, he might easily have included two prophecies in one. But the reference to the purchase of the field in Anathoth, mentioned in Jeremiah, is too vague and remote to be regarded as part of the prophecy.

Another hypothesis is that Jeremiah is designedly mentioned by the Spirit, in order to show the unity of prophecy. No doubt the prophecy is from Zechariah; but Jeremiah is named because both prophets were inspired by the same Spirit, both were penmen of the same Author. This strange solution is advanced by Augustine: "It may have been the case," he observes, "that when Matthew was engaged in composing his Gospel, the word Jeremiah occurred to his mind instead of Zechariah. Such an inaceuracy he would most undoubtedly have corrected, had he not reflected that it was not without a purpose that the name of one prophet had been suggested instead of another. . . . This might fitly suggest the duty of accepting unhesitatingly whatever the Holy Spirit has given expression to through the agency of these prophets, and of looking upon their individual communications as those of the whole body, and their collective communications as those of each separately. If, then, it is the case that words spoken by Jeremiah are really as much Zechariah's as Jeremiah's, and, on the other hand, that words spoken by Zeehariah are really as much Jeremiah's as they are Zechariah's, what necessity was there for Matthew to correct his lext when he read over what he had written, and found that the one name had occurred to him insteal of the other"? 1 It is singular that this most improbable, we night almost say extravagant, solution, wherein the Holy Spirit is regarded as justifying an inaceuracy, has been adopted by Bishop Wordsworth: "By referring here, not to Zechariah, where we read the passage, but to Jeremiah, where we do not read it, the

${ }^{1}$ Consensus Evv. iii. 7. 30. 
Holy Spirit teaches us not to regard the prophets as the authors of their prophecies, but to trace their prophecies, flowing down through them, in different channels from age to age, until we see them all at length springing forth from the one living Fountain of wisdom in the Godhead itself."

Others at once admit that Matthew has committed a mistake in attributing a prophecy of Zechariah to Jeremiah. They do not suppose that the inspiration of the sacred writers is inconsistent with slight errors in their writings. This opinion, first snggested by Origen, has been adopted by Calvin, Mill, Griesbach, De Wette, Meyer,', and Alford. Thus Calvin passes over the error with the remark: "How the name of Jeremiah crept in, I confess that I do not know, nor do I give myself the trouble to inquire. The passage itself plainly shows that the name Jeremiah has been put down by mistake instead of Zechariah; for in Jeremiah we find nothing of this sort, nor anything that even approaches to it." ${ }^{3}$ And Alford observes: "The citation is not from Jeremiah, and is probably quoted from memory, and inaccurately; we have similar mistakes in two places in the apology of Stephen - Acts vii. 4, 16, and in Mark ii. 26. Varions means of evading this have been resorted to, which are not worth recounting." 4 Such a solution certainly cuts the knot, but must only be resorted to as a last expeclient.

The mistake, for mistake we believe there is, need not necessarily be referred to the author, but to the copyist. Some think that the error originated in the translation of the Hebrew Gospel of Matthew into Greek. ${ }^{5}$ This, of course, assumes that the Gospel of Matthew was originally written in Hebrew, which, though probable, has not been demonstrated. If, however, there were a Hebrew Gospel of Matthew, it is a possible solution. But it might also

1 See Wright's Bampton Lectures for 1878, p. 336, note.

2 "The passage here quoted is a very free adaptation of Zech. xi. 12, 13, 'Ispsuiou being a slip of the memory." Meyer's Commentury on Mratthero, in loco.

3 Calvin, in loco.

4 Alford's Greek Testament on Matt. xxvii. 9.

5 Some suppose that the mistake may have arisen from the translator mistaking 7 (a contraction for Jeremiah) for 7 (hand). Hender'son, Com. on Zech. 
have arisen from the earliest copyist of Matthew's Gospel. "It is," says Dr. Morison, "a graphical crratum. And it would appear to have crept into the original edition of the Gospel, the first published edition. Hence its universal diffusion and its persistence from age to age. There is nothing wonderful in such an occurrence. It is precisely paralleled by the expression 'which strain at a gnat,' instead of 'which strain out a gnat,' in our English authorised translation of the Bible." 1 There is another example in 1 Tim. iv. 9, where the word shamefacedness is a typographical error for shamcfastncss, and is so read in the Revised Version. The word Jeremiah being found in the earliest copies of the Gospel would remain uncorrected, especially as it would be considered wrong to alter the scriptural manuscripts, and as the mistake admitted of various explanations. In some manuscripts, and in the Peshito Syriac, as we have seen, it was corrected. A mistake has been committed, and it is more justifiable to ascribe it to the copyist than to the author, or at least equally justifiable.

1 Morison's Commentury on Matthew. Note on Matt. xxrii. 9. Dr. Morison gires a long and exhaustive list of the various hypotheses which have been advanced, to which list we have heen indelited. 


\section{T'HE GOSPEL OF IIARK.}

Literature.-The prineipal eommentaries and dissertations on the Gospel of Mark are those of Petter on the Gospel of Mark (London, 1661); Fritzsche, Erangelium Marci (Leipzig, 1830); De Wette (Leipzig, 1846); Hilgenfeld, Das MarcusEvangelium nach seiner Composition, nach scincr Stellung in aler Exangelien Littcratur (Leipzig, 1880); Ewald (Göttingen, 1850); Baur, Das Mareus-Evangelium nach seincm Ursprung and Charalitcr (Tübingen, 1851); Olshansen (1853, English translation, 1863); Dr. Joseph Alexander of Prineeton (New York, 1S58); Alford in his Greek Testament (4th ed. London, 1859); Meyer (last ed. in 1894; 1st ed. 1860 ; 6th ed. 1878 ; English translation by the Rev. Robert Wallis, Edinburgh, 1880); Lange (Bielefeld, 1861; English translation by Professor Shedd, 1866); Klostermann, Das Mareus-Evangelium nach scinem Quellenuerthe für die Exangelisehe Geschichte (Göttingen, 1867); Weiss, Das Mareus-Evangelizm (Berlin, 1872); Morison (1st el. London, 1873; 3rd ed. 1881); Volkmar, Mareus und die Synopse der Evangelien (Ziirieh, 1S70); Canon Cook in the Spealier's Commentary (London, 1878); Maelear in Cambritge Bible for Sehools (London, 1856). Also Dean Burgon, The last twelve verses of the Gospel aceording to Mark (Oxford, 1871).

\section{The Genuineness of the Gospel.}

The genumeness of the Gospel of Mark is suffieiently attested. It is true that no undoubted citations from it ean be produced from the writings of the apostolic Fathers, 
beeause the resemblance between it and the Gospels of Matthew and Luke is so close as to render it impossible to determine from which of these Gospels the citations have been taken. The first undoubted reference to it is found in that famons passage, quoted by Eusebius from Papias' Aori $\omega \nu$ $\kappa \nu \rho \iota \alpha \kappa \hat{\omega} \nu \dot{\epsilon}^{\xi} \xi \gamma \eta \dot{\gamma} \sigma \epsilon \varsigma$ (i.D. 120), to which we have formerly adverted." "This also the Presbyter said: Mark, having become the interpreter of Peter, wrote down aceurately, though not indeed in order, whatever he remembered of the things said or done by Christ." 2 It is to be observed that Papias gives this statement on the authority of the Presbyter. Without doubt John the Presbyter is here meant, whether he be, as some suppose, the Apostle John himself, or a person, otherwise unknown, who was an immediate disciple of the Lord, and whose testim:ny consequently carries us back to the days of the apostles. It has indeed been maintained by many liblical crities that Papias eamnot here refer to our eanonieal Mark, but to some original document which lay at the foundation of Mark's Gospel, because his description does not correspond with our Gospel of Mark. We have already referred to this objection, ${ }^{3}$ and shall afterwards inore fully diseuss it.

Justin Martyr (A.D. 150) has the following direct citation from Mark: "It is said that He changed the name of one of the apostles to Peter; and it is written in his Memoirs that this oecurred, as well as that $\mathrm{He}$ ehanged the names of other two brothers, the sons of Zebedee, to Boanerges, which means the sons of thunder." ${ }^{*}$ This title given to the sons of Zebedee is only found in the Crospel of Mark (iii. 17).

The Muratorian eanon (A.D. 170) is mutilated at its eommencenent, but it evidently contained a reference to the Gospels of Matthew and Mark, for the fragment commences with the words: "The third Gospel is that aceording to Luke." 5

1 see 1. 19, where the original Greck is given.

2 Euselinus, Mist. Eirl. iii. 39.

3 see sume, I'l. 66, 67.

Hiul. c. Tryllh. ch. evi.

s Tertimn Evangelii libnun secumdun Lucan. 
Irenæus (A.D. 180) has many references to Mark, and directly affirms that he is the anthor of the second Gospel: "Wherefore also Mark, the interpreter and follower of Peter, does thus commence his Gospel narrative: The beginning of the Gospel of Jesus Christ, the Son of God." 1 "Also toward the conclusion of his Gospel, Mark says: "So, then, after the Lord Jesus had spoken unto them, He was received up into heaven, and sitteth on the right hand of God."." 2 "Those who separate Jesus from Christ, alleging that Christ remained impassible, but that it was Jesus who suffered, preferring the Gospel by Mark, if they read it with the love of the truth, may have their errors rectified." 3

Besides these quotations, there are the patristic statements of the intimate comnection which exists between the Gospel of Mark and the preaching of Peter, male by Irencus, Clemens Alexandrinus, Tertullian, Origen, and others, to which we shall afterwards refer. There is also the testimony of the two chief versions, the Syriac (A.D. 150) and the Old Latin (A.D. 170).

Nor are internal evidences wanting. The attribution of this Gospel to such a comparatively obscure anthor as Mark, is in itself a presumption in its favour. If the lesign was to impose it npon the Church, it would have been assigned to one of the chief apostles, especially to Peter, whose preaching, according to the Fathers, it contains, and not to one who was not an apostle, and perhaps not even a disciple, and who, provided he be the same as the Mark who is mentioned in the Acts, so far from being an eminent teacher in the Church, deserted Paul and Barnabas on their missionary journey. But especially does the Gospel contain in itself the evidences of its genumeness. The narrative is of the most graphic description; little incidents are mentioned which conld only be the observation of an eye-witness. ${ }^{4}$ There is a vividness, a freshness, and a naturahness in this Gospel which give it the stamp of truth.

${ }^{1}$ Adv. Her. iii. 10. 6.

2 Ibid.

${ }^{3}$ Ibid. iii. 11. 7.

${ }^{4}$ It is not necessary to assert that Mark himself was an eye-witness, but that the narrative contained in his Gospel was the report of an eyewitness. 
Yet notwithstanding these external and internal evidences in favour of the Gospel of Mark, its genuineness has been frequently disputed. The objections to it arise chiefly from the difficulties in which the question as to the origin of the Synoptic Gospels is involved, and not from any defect in the evidence. The first who called in question its genuineness appears to have been Schleiermacher, and he has been followed by Baur, Weisse, Gfrörer, Crelner, ${ }^{1}$ Schwegler, Hilgenfeld, Ewald, Köstlin, Reuss, Schenkel, and Dr. Samucl Davidson.

The chief objection brought forward is, that the statement of Papias is not applicable to our canonical Gospel of Mark. ${ }^{2}$ The genuineness of Mark's Gospel, it is asserted, rests entirely on the testimony of Papias; the other authorities come too late. But the description which lapias gives of the writing of Mark camot apply to our canonical Cospel. Papias asserts that Mark, the interpreter of Peter, wrote down accurately, but not in order (ov $\tau a^{\prime} \xi \in$ ), whatever he remembered of the things said or done by Christ; and that he followed l'eter who adapted his discourses to the needs of his hearers, but "with no intention of giving a comnected

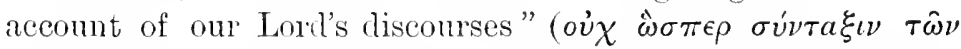

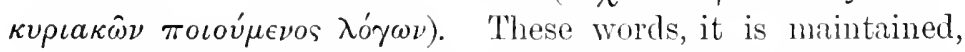
camot refer to the Gospel of Mark, as we now possess it, because that Crospel, so far from not being written in order and destitute of connection, is the most orderly and connected of the three synoptic Cospels; indeed it is on its ehronological oreler that harmonies of the Gospels are in general former.

It is to be observed that this is the mere opinion of Papias, or of the Preshyter to whom he refers, and that on a subject which almits of a variety of opinions: nor ale his words to be pushed too far. There is a considerable variety of opinion as to what Papias intends by ov $\tau a \dot{a} \xi \iota$. Tholuek suploses that he refers to the incompleteness of the Gospel,that Mark merely gives a collection of anecelotes withont observing any definite order with regard to the time of the oceurrence of the incilents stated. Schenkel suploses that the words

${ }^{1}$ Einleitum, ]13. 123, 124.

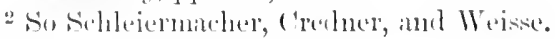


indicate the occasional manner of Mark's writing; that he did not compose his Gospel continuously at one time, but in parts at various times. Others think that ov $\tau \alpha^{\prime} \xi \epsilon \iota$ refers, not to the actions, but to the discourses of Christ, and indicates that Mark gave no continued account of our Lord's

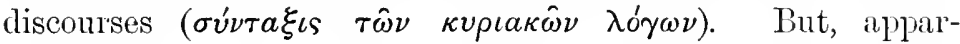
ently, what he affirms is not that there was no order in the composition of Mark's Gospel, but that the events are not related in a chronological order. Papias asserts the accuracy of the events which Mark relates, that "Mark wrote down accurately every thing that he remembered," that "Mark committed no error," but for some reason he was dissatisfied with his arrangement. The want of chronological order is to some extent applicable to all the three Synoptics. The evangelists did not relate the events of the life of Christ chronologically; they do not profess to give a biography of Christ; their Gospels rather consist of memorabilia or collections of the remarkable incidents in His life. The words of Papias are to be understood comparatively. It is disputed with what Gospel he compares the order in Mark. Some suppose that Matthew's Gospel, to which he afterwards alludes, was in his view; others, as Ewald and Bishop Lightfoot, think that it is the order followed in the Gospel of John; Dr. Salmon thinks that what Papias regarded as the right order was that of the Gospel of Luke. ${ }^{1}$

It has been maintained that there must have been an original Gospel of Mark, of which our canonical Gospel is a recension. Those who adopt this opinion suppose that a collection of incidents in the life of Jesus, based perhaps, as the Fathers testify, on the preaching of Peter, was drawn up by Mark, one of his disciples, without any order, and that it is to this collection that l'apias alludes. Afterwards, it is supposed, a succeeding writer composed the second Gospel, taking this original gospel as his basis, arranging the incidents in order, and adding to them additional material drawn from oral tradition.

We have already referred to this hypothesis of an original Mark, ${ }^{2}$ and shall not again recur to it. Those who

\footnotetext{
${ }^{1}$ Salmon's Introduction, 1. 121.

${ }^{2}$ See supra, pp. 66, 67.
} 
adopt it differ widely as to its nature and extent. Ewald and Holtzmam suppose that the original Mark was longer than our present Grospel, containing a greater number of the ineidents and diseourses of Christ than our present Mark. Paul Ewald supposes that i. 1-8, vii. 24, viii. 26, and xvi. 9-20 are interpolations. ${ }^{1}$ Weizsiicker, on the contrary, considers that it was shorter, and that our present Mark is an enlargement. In the writings of the Fathers there is no reference to a Cospel of Mark different from that which we now possess. "The assumption," olserves Meyer, "of an original treatise which has been lost would only have a historical point of support in the event of the contents of the fragment of Papias, so far as it speaks of the treatise of Mark, not really suiting our canonical Mark. But since, on a correct interpretation, it contains nothing with which our Mark is at variance, and therefore affords no ground for the assertion that it is speaking of another book ascribed to Mark, it remains the most aneient and the most weighty historical testimony for the originality of our second Gospel, and, at the sime time, for the high historical value of its contents." 2

\section{Tine Authol of the Gospel.}

This Gospel has been miformly assigned by the Fathers to Mark; it is known in the Greek mamuseripts of the New

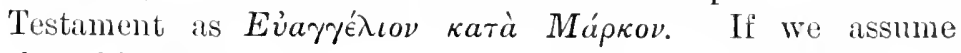
that this Mark is the same as he who is mentioned in the Acts of the Apostles, the following incirlents in his life are reeordecl. He was a Jew by birth, heing mentioned by Paul as among those of the circumeision (Col. iv. 10, 11), and bore the Hebrew name of John. But, like many of his time, he had also the Roman name of Mark. Hence he is called "John, whose smlname was Mark" ('I нерољ Ма́ркоя, Aets xii. 12, 25, xr. 37). In the Aets he is generally called by his Hebrew name John (Aets xiii. $5,13)$; whilst in the Elistles and in the Fathers the Hebrew name is dropled and the Latin nane Mark retained. We

'Ewald, Patul, Erengelienfreter, 1'l. 165, 170, 178-191.

2. Meger's Commentery on Aturk, rol. i. Eng. trans, 1. 12. 
learn that his mother's name was Mary, and that she had a house in Jerusalem, where the disciples were accustomed to assemble (Acts xii. 12). In the Epistle to the Colossians (iv. 10), Mark is called ó àvє either denote nephew or cousin ; in the Revised Version it is translated cousin. From this relationship to Barnabas it has been arbitrarily inferred that he was a Levite. It was probably by reason of this relationship that he was brought in contact with Paul; for we read that Barnabas and Saul returned from Jerusalem, and took with them John, whose surname was Mark (Acts xii. 25). He accompanied these apostles on their first missionary journey as their assistant

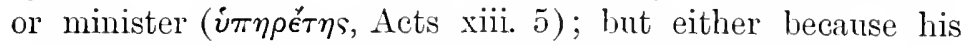
zeal waxed cold, or becanse the dangers and difficulties of the mission alarmed him, he deserted them at Perga, and returned to Jerusalem (Acts xiii. 13). Four years afterwards, when Paul and Barnabas proposed to proceed on a second missionary journey, Mark was the occasion of a dispute between them; Barnabas wished to take him with them, but Paul refused on account of his previous desertion; and accordingly Paul took Silas, whilst Barnabas took Mark, and departed with him to Cyprus (Acts xv. 39). This is the last notice which we have of Mark in the Acts of the Apostles. But from Paul's Epistles we learn that he was afterwards fully reconciled to Paul. $\mathrm{He}$ was with that apostle during his first Poman imprisonment, when he wrote the Epistles to the Colossians and Philemon (Col. iv. 10; Philem. 24). He afterwards appears to have journeyed into Asia, for during his second Roman imprisonment Paul writes to Timothy: "Take Mark, and bring him with thee: for" he is useful to me for the ministering" (2 Tim. iv. 11).

Such is the scriptural account of the connection between Mark, the relation of Barnabas, and Paul. But there is also mention of a Mark in the First Epistle of Peter written from Babylon, or, as some think, from Rome. There we read: "She that is in Babylon, elect together with you, saluteth you; and so doth Mark my son" (1 Pet. v. 13). Some (Bengel, Neander, Credner, Tholuck, Dean Stanley) suppose that, when Peter calls Mark his son (o viós $\mu o v$ ), he does not 
allude to a spiritual, but to a natural relationship. Thus Dean Stanley observes: "It is diffieult to resist the conclusion that $\dot{\eta} \sigma v \nu \epsilon \kappa \lambda \epsilon \kappa \tau \eta \dot{y}$ is the wife of Peter; and if so,

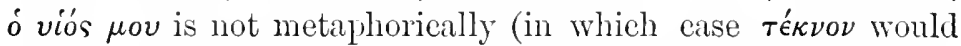
be the natural word, as in 1 Tim. i. 2), but literally, his son." 1 But such an opinion is unfounded. There is no reason why Peter and I'aul should not employ different words to express a spiritual relationship. Peter calls Mark his son, because he was converted by him; he was his spiritual father.

We have said that these incilents refer to Mark, the evangelist, on the assumption that he is the same person as is mentioned in the Aets and in the Pauline Epistles. Some, however, suppose that there are two Marks; one mentioned in the Acts, who was the companion of Paul, and another mentioned in the First Epistle of Peter, who was the companion of Peter. This opinion has been adopted by Grotius,2 Schleiermacher, Cornelius a Lapide, Cave, ${ }^{3}$ Greswell, ${ }^{4}$ Baring-Gould, 5 and Dr. David Brown of Aberdeen. There is nothing unreasonable in this supposition, nor is it contradicted by any of the statements of the Fathers of the first three centuries. The reasons for it are that Mark is in Scripture, with the exception of 1 Pet. v. 13, uniformly represented as the associate of Paul and Barnabas; and there is no allusion to any connection between him and the Apostle Peter. He was with Paul at Rome (Col. iv. 10 ; Philem. 24; 2 Tim. iv. 11), and could hardly approximately about the same time have been with Peter at Babylon (1 Pet. v. 13). Besides, Mark or Mareus was a very common name, bor'ne by many illustrious Romans, as Mareus Tullius Cicero, Mark Antony, and the emperor Marcus Aurelius. Hence it has been inferred that there must have been two Marks, and that it was not Mark the relation of Barnabas, but another Mark, the companion and interpreter of P'eter, who was the anthor of the (iospel.

I Stinley's Sermons and Essetys on the Apostolic 1ye, 1. 91, note.

2 Grotius, l'roumium in Hetreum.

3 Care's lives of the Apostles, P' 439.

4 Gueswell's Inisertations, vol. i. p. 71.

"Jintring-Gould's Lives of the Seints, Alril 25. 
On the other hand, it has been maintained that this supposition is unneeessary, and that Mark might be the companion both of Panl and Peter. After Mark had separated from Paul at the commencement of his first missionary journey and returned to Jerusalem, he might have attached himself to Peter in that city; and after he had left Barnabas in Cyprus, he might have been with Peter in the interval between that and Paul's imprisonment at Rome. Besides, a conneetion between Peter and Mark is hinted at in the Acts: it was to Mark's house that Peter betook himself after his miraeulous deliverance from prison (Acts xii. 12). "To suppose two Marks," says Dr. John Lightfoot, "one with Peter and another with Paul, is to breed confusion where there needeth not, and to conceive that for which Scripture hath not only no ground, but is plain enough to the contrary. It is easily seen how John Mark came into familiarity both with Panl and Peter; and other Mark we can find none in the New Testament, unless of our own invention." 1 There is much, however, in favour of the theory that there were two Marks, a supposition which would remove several difficulties which arise from the long continued connection of Mark with Paul, rendering a connection with Peter improbable.

It has been supposed that Mark was the young man mentioned in his Gospel who followed Christ after all the disciples had fled, when He was led from Gethsemane to the palace of Caiaphas (Mark xiv. 52). It is narrated by the evangelist as a personal incident in a most graphie manner. Disturbed in his sleep by the tumult, and not taking time to put on his elothes, he threw a linen sheet over him, and rushed into the street to see what was the cause of the tumult: the soldiers seized him, and he left the linen eloth in their hands, and fled naked." The objection to this is, that aecording to the statement of Papias, Mark was not one of Christ's diseiples: "he neither heard the Lord nor followed Him"; so that if Mark himself is the person

${ }^{1}$ Lightfoot's $W_{0} \%$ s, vol. iii. p. 323, edition by Pitman.

2 See Greswell's Dissertations upon a Hurmony of the Gospels, vol. i. p. 82, edition 1830 . 
alluded to in lis Gospel, we must suppose that Papias was mistaken. The Mark mentioned in the Acts was at least at a very early period a disciple of Christ. Other's go the length of supposing that it was in Mark's house that our Lord and His disciples met to celebrate the last Passover: that, being a diseiple, and having a house in Jerusalem, he gave it up for the use of our Lord. ${ }^{1}$ This, however, is a mere conjecture which rests on a very slender foundation.

There are several notices of Mark in ecelesiastical history. According to Epiphanius, he was one of Christ's seventy disciples, and one of those who left Christ on account of His words: "Except ye eat My flesh and drink My blood, ye have no life in you" (John vi. 66), but was afterwards reclaimed, and, as it were, reconverted by Peter, whose spiritual son he became. ${ }^{2} \mathrm{He}$ is uniformly known by the Fathers as the interpreter of Peter. $\mathrm{He}$ is represented as the founder of the Egyptian Chureh. Eusebius informs us that "Mark was the first who was sent to Egypt, and that he preached the Gospel which he had written, and established churches in Alexandria. $^{3} \quad$ The multitude of believers that were collected there, and lived lives of the most philosophical and excessive asceticism, was so great, that Plhilo thought it worth while to describe their pursuits, their meetings, their entertainments, and their whole manner of life." 4 The allusion is to the Therapeute whom Philo describes; but they were not Christians, and hence this statement of Eusebius must be considered as legendary; ${ }^{5}$ though it may be assumed that Mark converted numbers in Alexandria, and that his preaching was of an ascetic character. Jerome tells us that Mark died a mitural death in the eighth year of Nero, and that he was buried at Alexandria." Niceplorus, on the other hand,

1 Farrar's Messictes of the livolis, 1. 5is, note 4.

2 Ejphininis, Herr. li. 6.

3 That Mirk fommled the Church of Alexamlria is also asserted by

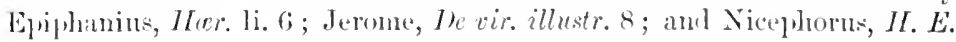
ii. 42.

${ }^{4}$ Euselinus, Mist. Eed. ii. 16.

5 The Theriprentie were in Jewish sect. Eusebins probably confounds them with the Christian monks.

"le vir. illestr. ch. viii. 
informs us that he suffered martyrdom, being cruelly put to death by an Alexandrian mob. ${ }^{1}$ His remains were believed to have been removed to Venice, of which city he was regarded as the patron saint, and where one of the most magnificent churches in the world has been erected to his memory.

\section{The Sources of Mark's Gospel.}

The inquiry into the sources from which Mark derived the materials for his Gospel is one of much difficulty. These sources were not, as is maintained by Griesbach and Bleek, the Gospels of Matthew and Luke. This point we have in the previous part of this Introduction fully discussed.2 Mark was not a compiler from previous Gospels. His own Gospel is original and independent, and in all probability was written and published before the other two.

On the other hand, it is the uniform testimony of the Fathers that Mark was intimately associated with Peter as his interpreter. This is a tradition which is both general and undisputer. It is first mentioned by Papias in the

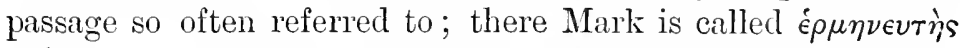
П'́трou. Ireneus says: "Mark, the disciple and interpreter

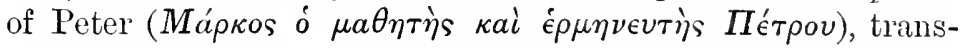
mitted to us in writing these things which Peter had preached." ${ }^{3}$ Clemens Alexandrinus, according to Ensebins, says: "The Gospel according to Mark, had this occasion: As Peter had preached the word publicly at Rome, and declared the gospel by the Spirit, many that were present requested that Mark, who had followed him for a long time, and remembered his sayings, should write them ont. And having composed the Gospel, he gave it to those who had requested it. When Peter learned this, he neither directly forbade nor encouraged it." ${ }_{4}$ Tertullian writes: "The Gospel which Mark published may be affirmed to be Peter's, whose interpreter Mark was." 5 Origen, quoted by Eusebius, says:

1 Nicephorus, Hist. Eccl. ii. 43.

2 See supra, pp. 46-48.

${ }^{3}$ Ireneus, Adv. Herr. iii. 1.1 ; Eusebins, Hist. Eccl. v. 8.

${ }^{4}$ Eusebius, Hist. Eccl. vi. $14 . \quad{ }^{5}$ Tertullian, Adv. Murcion. iv. 5. 
"The second Gospel is that according to Mark, who wrote it according to the instructions of Peter." 1 Eusebius writes at length coneerning the Gospel of Mark. "So greatly did the splendour of piety illumine the minds of Peter's hearers, that they were not satisfied with hearing once only, or with the unwritten teaching of the divine Gospel, but they besought Mark - a follower of Peter, and the one whose Gospel is extant-that he would leave them a written monument of the doctrine which had been orally communicated to them. Nor did they cease until they prevailed upon him; and such was the oceasion of the written Gospel which bears the name of Mark." ${ }^{2}$ And to the same effect Jerome observes: "Mark, the disciple and interpreter of Peter, at the desire of the brethren at Rome, wrote a short Gospel, according to what he had heard related by Peter." 3

From these testimonies it must be admitted that the preaching of Peter had some influence in the formation of the Gospel of Mark. It has been affirmed that traces of this influence and of this comnection between Mark and Peter are to be discerned in the Gospel itself. ${ }^{4}$ There is frequent mention of Peter in places where he is not alluded to in the other Gospels, as if it were the writer's desire to record facts concerning him of which he had been personally informed. Thus we are told that Simon and those that were with him followed Jesus after the miracles at Capernaum (i. 16); that it was Peter who drew the attention of our Lord to the withering of the fig tree (xi. 13); that Peter, along with John, James, and Andrew, asked our Lord concerning the sign that should precede the destruetion of Jerusalem (xiii. 3); and that the angel who ammounced the resurrection of Christ to the women, specified Peter as the person to whom the amnouncement should be made: "Tell His disciples and l'eter" (xvi. 7). But, on the other hand, there are also numerous instanees where leter is onitted in the Gospel of Mark, while men-

1 Eusehins, Thist. Eicl. vi. 25.

2 Ibid. ii. 15.

3 Jerome, De vir. illustr. ch. viii.

4 See Dorls' Introtuction to the N.T. plp. 26-28; Klostermann's Marcus-

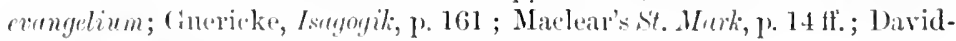
son's Introduction to the N.T. vol. i. l'l. 145-1.47. 
tioned in the other Gospels. Thus in Matt. xv. 15, Peter is represented as asking the explanation of a certain parable, whereas Mark has simply "the disciples." The blessing pronounced on Peter (Matt. xvi. 16-1S), Peter walking on the sea (Matt. xiv. 28, 29), and his capture of the fish in which was found the Roman coin (Matt. xvii. 24-27), are omitted by Mark. His mission along with John (Luke xxii. 8) to prepare the Passover, and the fact that he accompanied John to the sepulchre (John $x x .2$ ), are not mentioned. It has indeed been suggested that these omissions may be accounted for by the humility of Peter, and from his relnctance to allude to anything that might redound to his praise; but, not to mention that it is difficult to see how this could affect the narrative of Mark, there are several instances of omission to which this remark cannot apply. Upon the whole, we do not think that the connection between Mark and Peter can be discovered by any traces in the Gospel itself.

Different meanings have been attached to the expression

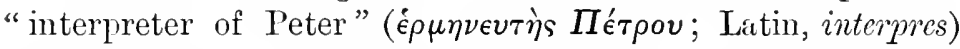
given by Papias and Irenæus to Mark. Some think that the word is to be taken in the sense of translator; that Mark translated into Greek (Eichhorn, Kuinoel, Schleiermacher) or into Latin (Bleek) what Peter preached in Aramaic; or that Mark translated into Greek Peter's Aramaic Gospel (Smith of Jordanhill). But there is no reason to suppose that Peter was ignorant of Greek, as it was one of the languages of Galilee, and his Epistles prove his acquaintance with it; and Latin was not required even in Rome, as Greek was the usual language of the Roman converts; nor is there the slightest trace of an Aramaic original of Peter's Gospel. Others-Meyer, Tholuck, Klostermann after Jerome-take the word in the sense of amanuensis or secretary, and suppose that Mark wrote down the oral teaching of Peter. Thus Jerome observes that as Paul employed Titus for his interpreter, so Peter employed Mark, whose Gospel was composed by the apostle dictating and the evangelist writing. " But the probability is that Mark is called "the 
interpreter of Peter," because his Gospel contains the substance of Peter's preaching, and thus interpreted that preaching to the Church. The tradition is so early and universal, that we must allow some connection between the Gospel of Mark and the preaching of Peter, yet not to the extent of supposing either that Mark wrote his Gospel to the dictation of Peter (Origen, Jerome), or that it contains a mere literal repetition of Peter's preaching.

In accordance with these testimonies of the Fathers, we infer that one of the somees of Mark's Gospel was the preaching of Peter, though how far the Petrine element entered into it we cannot determine. Mark, as the companion and interpreter of that apostle, collected notes of his preaching, and by their aid constructed his Gospel. Two of the Fathers of the early Chureh, Justin and Tertullian, appear actually to have regarded it as the Gospel of Peter. Justin Martyr, in a passage alrealy quoted, says that Christ changed the name of one of His apostles to Peter ; and it is written in

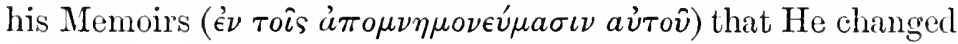
the names of other two apostles to Bonnerges. ${ }^{1}$ The question is, What are the Memoirs to which Justin alludes? It has been affirmed that the nost natural interpretation is to refer

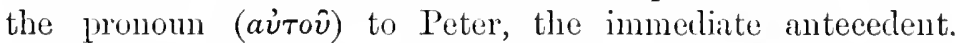
Lardner and De Wette refer it to Christ; His Memoirs, that is, the Memoirs eoncerning Christ. But to this it is answered that Justin always uses the genitive of authorship-the Memoirs of the apostles, so that the phrase would denote Peter's Menoirs. Iut although the meaning of these words may be cloubtful, yet Tertullian expressly calls Mark's Gospel the Gospel of Peter: "The Gospel which Mark published may be affirmed to be Peter's, whose interpreter Mark was." ${ }^{2}$

But besides the oral teaching of Peter, the gencral oral tradition of the Church formed another source of the Gospel of Mark. An oral Gospel for the instruetion of eatechumens would be formed at an early period, and, as we have had alrealy occasion to observe, woukl enter langely into the

I.Justin Martyr, Dinl. c. Trynh. ch. cvi. Ottu, an editor of Justin, thinks that for airoz̃ we ought to read airoẁ.

${ }^{2}$ Ade. Alercion. iv. 5. 
formation of the Synoptic Gospels. Besides, we must also remember that Mark was a native of Jerusalem and an early convert to Christianity; and, consequently, would have ample opportmities for collecting particulars concerning the life of Christ by his intercourse with those who were the personal followers of Christ and the hearers of His discourses.

\section{The Design of the Gospel.}

Clemens Alexandrinus gives an account of the occasion on which Mark's Gospel was composed. He tells us that the disciples requested Mark to write down the sayings of Peter, and not to leave them to the uncertainty of tradition; and that this was done with Peter's knowledge and concurrence. ${ }^{1}$ We cannot tell what truth there is in this statement: in all probability there is much that is legendary about it, and it contradicts other statements of the Fathers. This Gospel was donbtless written for the purpose of giving a connected view of the life of Christ and of gathering together those evangelical fragments, whether oral or written, which were dispersed throughout the churches. Christ is represented in this Gospel as the active agent, the worker of miracles: as at once the Son of God and the Son of Man; revealing Himself as God by His mighty words, and as Man by His human personality and human feclings: it is "The Gospel of Jesus Christ, the Son of God" (Mark i. 1). Peter's statement of the testimony of the apostles: how "God anointed Jesus of Nazareth with the Holy Ghost and with power; who went abont doing good, and healing all that were oppressed of the devil: for God was with Him" (Acts x. 38), has well been described as the programme of this Gospel. Whilst Matthew records the discourses of Jesus, Mark dwells chiefly on His actions.

It is probable, from various indications, that this Gospel was written, not like that of Matthew, for Jewish, but, like that of Luke, for Gentile Christians. There are in it several Latin words and expressions. Of these Credner specifies

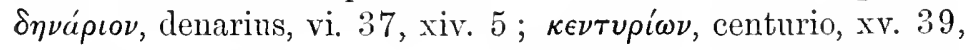

${ }^{1}$ Eusebius, Hist. Eccl. vi. 14. A similar statement is made by Eusebius himself, Hist. Eccl. ii. 15. 
44, $45 ; \kappa \hat{\eta} \nu \sigma o s$, census, xii. $14 ; \kappa о \delta \rho \dot{\nu} \tau \eta s, q u a d r a n s, x i i .42$;

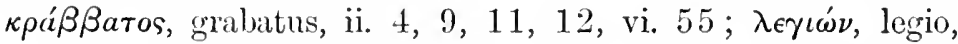

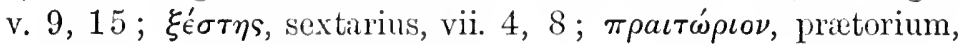

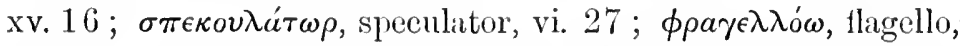

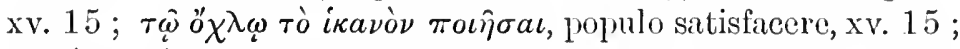

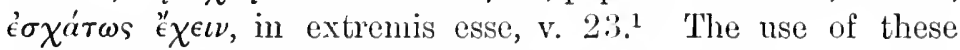
Latin words and phrases will be best accomited for, if the ordinary supposition is correet, that Mark wrote chiefly for the Romans.

So also translations are attached to Aramaic words and expressions for the information of Gentile readers who were ignorant of that language. Thus our Lord called James and John, "Boanerges, that is, the sons of thunder" (iii. 17). In raising the daughter of Jairus, our Lord said to her, "Talitha cumi ; which is, being interpreted, Damsel, I say unto thee, Arise" (v. 41). The pharisaical Jews exensed their" want of filial affection by offering gifts to God, saying, "It is Corban, that is, given to God" (vii. 11). When Jesus took the blind man aside privately, "He said unto him, Ephphatha, that is, Be opened" (vii. 34). The name of the blind man who was cured at Jericho was Bartimeus, the son of Timaus (x. 46). In Gethsemane our Lord used the word Abba, that is, Father (xiv. 36). The place where He was crueified was called "Golgotha, which is, being interpreted, the place of a skull" (xv. 22). And on the cross our Lord exelaimed, "Eloi, Eloi, lama sabachthani? which, being interpreted, is, My Gor, My God, why hast Thou forsaken Me?" (xv. 34).

Jewish customs and usages are often explained, as if for the information of Gentile readers. Thus we are informel that the Pharisees and all the Jews, except they wash their hands, eat not, holding the tradition of the elders (vii. 3); that the disciples of John and of the l'harisees used to fast (ii. 18); that the Sadrlacees saly, there is no resurrection (xii. 18); that on the first diay of unleavened bread, the Passover was killed (xiv. 12); that at the Passover the Romans were aceustomed to release to the Jews a prisoner, whomsoever they desired (xv. 6); that the preparation was the day before the Sabbath (xv. 42). So also localities which woukl be well known to ${ }^{1}$ Credner's Einleitung, 1. 104. 
Jewish, but not to Gentile readers, are explained. The Jordan is called the river of Jordan (i. 5); the Mount of Olives is over against the temple (xiii. 3). The Jewish law is nowhere alluded to ; indeed the word $\nu$ ó $\mu$ s, of sueh frequent oeeurrenee in the New Testament, does not oecur.

\section{Language of the Gospel.}

Baronius, Bellarmine, and other Catholie writers suppose that the Gospel of Mark was written in Latin. The reason assigned for this opinion is that the readers of this Gospel were Romans or Latin Christians. It is also supported by the two Syriae versions, the Peshito and the Philoxenian. Thus a note appended to the Peshito says: "This is the end of the holy Gospel preached by Mark, who preached in lioman at Rome." And Seholtz mentions four Greek manuseripts in which it is asserted that the Gospel was written in Latin. ${ }^{1}$ But such an opinion is undoubtedly ineorrect; the Greek and Latin Fathers manimously testify that the Gospel was originally written in Greek.

The style and diction of Mark is graphie and vivid. There is a preferenee for the present to the historieal tense; events are represented as happening before our eyes, imparting a vividness to the deseription. Thus: "There comes to Him a leper, beseeching Him" (i. 40). "They eome to Him, bringing one siek of the palsy, borne of four" (ii. 3). "And straightway, while he was yet speaking, comes Judas, one of

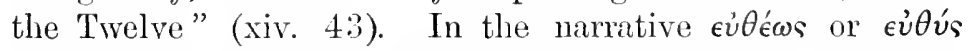
frequently oecurs as the partiele of transition, imparting a lively eharacter to the narrative; it oeeurs thirty-niue times, and is in the Authorised Version variously translated by the words straightway, immediately, forthwith. There are numerous references to persons, whieh impart a graphie character to the narrative; thus: "The Pharisees took counsel with the Herodians" (iii. 6); "Judas, whieh betrayed him" (iv. 11); Simon, "the father of Alexander and Rufus" (xv. 21). There are minute descriptions of loealities: "He began to teach by the seaside" (iv. 1); "He was in the stern asleep on the

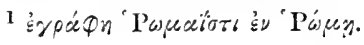


cushion" (iv. 38): "they find a colt tied at the door withont, in the open street" (xi. 4); "He commanded them to sit down by companies upon the green grass" (vi. 39). There are precise statements of periods of time: "at even, when the sun did set" (i. 32); "in the morning, a great while before day" (i. 35); "on that day, when even was come, He said unto them, Let us go over to the other sicte" (iv. 35).

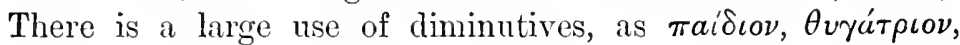

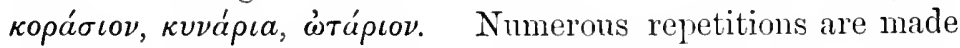
to add force to the narrative; as the accumulation of negatives,

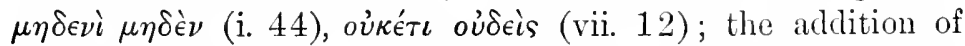
similar expressions, as when it is saicl: "And with many. parables spake He unto them: and without a parable spake He not unto them" (iv. 33, 34). There is also a large number of words which are peculiar to this Gospel. ${ }^{1}$

There are nineteen quotations from the Old Testament in Mark's Gospel, but these are all common to Matthew and Luke, often agreeing verbally. All these quotations are given in reporting our Lord's discourses; there is only one (i. 2, 3) which Mark gives as from himself.

The following is the list of them:-

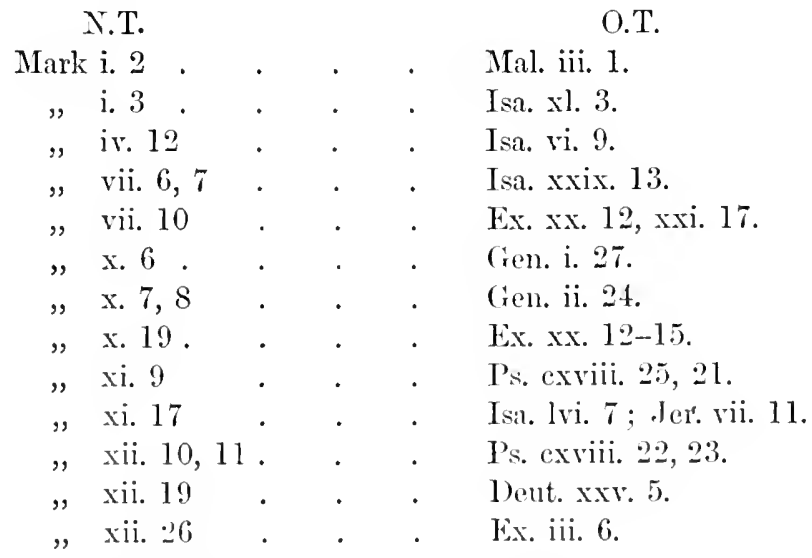

1 See Crerlner's Finleitum in eles N.T. 102-105; 1)avidson's Introduction to the N.T. val. i. W. 150-152; and his Introduction to the Study of the N.T. vol. ii. 3rl ed. 1). 521-523; Gnericke's N.T. Istugyili, pl. 162, 163 ; ant Schittl's History of the Church, vol. ii. 1)! (63--639. 
N.T.

Mark xii. 29, 30 .

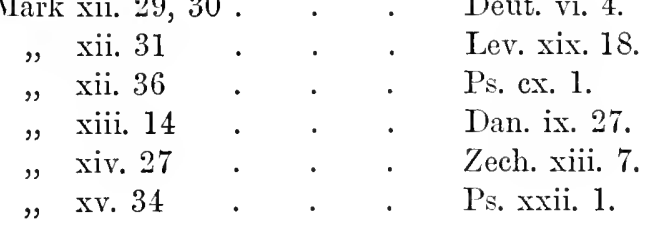

One peculiar feature of the Gospel of Mark is its brevity. It is of much smaller compass than the other Gospels; there is little that is peculiar to it-only one parable and two miracles. Most of the discourses which are in the other Gospels are omitted. And yet this brevity consists rather in the omission of particulars than in condensation. What is common to the other two is often expanded by Mark by the addition of minute particulars.

The chief characteristic of this Gospel is its vividness. The narrative is picturesque, so as to secure for the evangelist the name of a "word-painter." The transactions are described as if we saw them with our own eyes; minute touches lighten up the whole subject. One scene may be selected for illustration. If we compare the account of the cure of the demoniac lad, when our Lord descended from the mount of transfiguration (ix. 14-29), with the narratives in the other two Gospels (Matt. xvii. 14-21; Luke ix. 37-48), the graphic nature of Mark's description will at once be seen. ${ }^{1}$ Mark alone tells us that when our Lord came down from the mount, He saw a great crowd about the disciples, and the scribes disputing with them. And when all the people beheld Him they were greatly amazed, probably because some vestiges of His glory were still seen on His countenance, and rumning to Him they saluted Him. Mark alone tells us that when they bronght the lad to Jesus the spirit tare him grievonsly, and he fell to the ground, and wallowed, foaming. He alone gives us, in a most graphic manner, the conversation between the father of the lad and our Lord. "And He asked his father, How long time is it since this hath come unto him? And he said, From a child. And oft-times it hath cast him both in to the fire

1 This is well exhibited in Rushbrooke's Synopticon, p. 60 ; also Abbott and Rushbrooke's Common Tralition of the Gospels, pp. 70-72. 
and into the waters to destroy him; but if Thou eanst do anything, have compassion on us, and help ns. And Jesus said unto him, If thou eanst, all things are possible to him that believeth. Straightway the father of the ehild cried out, and said, I believe; help Thou mine unbelief." Then we are told the erowd came rushing together; and when Jesus commanded the unclean spirit to eome out of the lad, the spirit cried and rent him sore, and the lad fell into such a death-like faint that the greater part of the crowd said he was dead. Int Jesus came and took him by the hand and raised him up. The whole scene is graphieally deseribed, as by the hand of a painter - the epileptie fit that seized the boy, the erowd rushing together, the agony and earnestness of the father, and the dignity and majesty of Christ, are all vividly portrayed before ns.

Mark, more than the other evangelists, represents Jesns as $\mathrm{He}$ aetually lived and walked on this earth. There is a peenliarly realistic character about this Gospel; Jesus Christ, the Son of Man and the Son of God, is evidently set forth before us. His feelings are disclosed: how the grieved for the hardness of men's hearts (iii. 5); how, looking up to heaven, He sighed (vii. 34); how He loved the rich young man who came asking what he should do to inherit eternal life (x. 21); how Ile was moved with indignation with His disciples when they sought to prohilsit little ehildren to be brought to IIm (x. 14); how He was moved with compassion for the people who followed Hin (vi. 34); and how He marvelled at the unbelief of IIis hearers (vi. 6). So also His aetions and gestures are deseribed: He turned about and looked on His cliseiples when He administered the severe rebule to l'eter (viii. :3:); He took up the little child in His arms (ix. 36); He put Ilis fingers into the ears of the deaf-mute, and did spit and tomehed his tongue (vii. :3:3); when the wonan with the issue of bloorl toneled His garment, He lonkerl round to see who had done it (v. :32); He fell asleep from fatigue in the stern of the brat (iv. 38). The very words which He spoke in Aranaie are given. We almost hear the accents of His

${ }^{1}$ Ralphatl's great pinture of the 'Thanstiguration is chielly taken from the description in Mark. 
voice. All is brought vividly before us; the scenes are photographed, so that we see them. Jesus is followed by the multitudes of Galilee; He can find no place for retirement; there is no room even about the door of the honse where He was; the multitude come together; so that they camnot so much as eat bread (iii. 20,21$)^{1}$

The Gospel of Mark is, as we have seen, no abbreviation of Matthew and Luke. In neither of these Gospels is Jesus so vividly displayed before us. He is in this Gospel seen to be in all points tempted like as we are, with the notable exception of being without sin; $\mathrm{He}$ is actuated by human feelings; $\mathrm{He}$ is subject to human wants; $\mathrm{He}$ is a great Personality whom we see and know. "I regard," observes Dean Alford, "the existence of the Gospel of Mark as a gracious and valuable proof of the aceommodation by the Divine Spirit of the records of the life of our Lord to the future necessities of the Church. While it contains little matter of fact which is not related in Matthew and Luke, and thus, generally speaking, forms only a confirmation of their more complete histories, it is so far from being a barren duplicate of that part of them which is contained in it, that it comes home to every reader with all the freshness of an individual mind, full of the Holy Ghost, intently fixed on the great object of the Christian's love and worship, reverently and affectionately following and recording His positions, and looks, and gestures, and giving us the very echo of the tones with which He spoke." 2

\section{INTEgilty OF the GOSPEL.}

In considering the integrity of Mark's Gospel, we come to the important discussion on the gemineness of its last twelve verses. ${ }^{3}$ Some of the most distinguished crities suppose that Mark ended his Gospel at the close of the eighth verse of the

${ }^{1}$ See Maclear on the Gospel of Murk, 1'p. 16-20: Cumbridge Lible for Schools.

2 Alford's Greek Testument, vol. i. 1. 39, Prolegomena, last ed.

3 This snbject is discussed at considerable length by Dean Burgon in his able monograph, The last tuelve verses of St. Murk; by I)r. Hort in The New Testument in the Original Grect: by Westcott and Hort, Notes on Select Readings, vol. ii. pp. 28-51; by Scrivener in his Introduction to the 


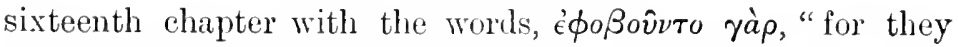
were afraid," and that what follows (Mark xvi. 9-20) was an addition by some other writer. This is the view taken in the Revised Version: a space is put between the eighth verse and the rest of the chapter, along with the footnote: "The two oldest Greek manuscripts and some other authorities omit from ver. 9 to the end. Some other authorities have a different emling to the Gospel." The first critic who called in question the genuineness of these verses was Griesbach, and he has been followed in recent times by several distinguished crities. Tischendorf, who has been justly called "the first biblical critic in Europe," says "that these verses were not written by Mark is proved by sufficient argunent." ${ }^{\text {Dr. }}$ Tregelles says: "The Book of Mark himself extends no farther

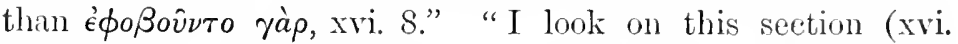
$9-20)$ as an authentic anonymous addition to what Mark himself wrote down from the narrative of St. Peter, and that it onght as much to be received as part of our second Gospel as the last ehapter of Deuteronomy, unknown as the writer is, is received as the right and proper conchusion of the books of Moses." 2 Dean Alford gives the following as the result of his examination of the passage: "The inference seems to me to be that it (Mark xvi. 9-20) is an authentic fragment, placed as a completion of the Gospel in very early times, by whom written must, of course, renain wholly uncertain; but coming to us with very weighty sanction, and having strong elaims on our reception and reverence." 3 Meyer expresses his view of the subject in the following terms: "The entire section, from vers. 9-20, is a non-genume conchusion of the Gospel, not composer by Mark." ${ }^{4}$ Its genumeness is also denied by Bishop Westeott: "The original text, from whatever cause it may have happened, terminated abruptly after the account of the angelie vision. The history of the revelations of the Criticism of the New Testement, 1]. 429-432, 1st ed.; vol. ii. 1p. 337-444, 4thed.; and ly T'regelles on the Printed Tert of the New Testoment, pp. $246-261$.

1 Hee non a Mareo seripta ese argumentis prohatur idoneis, in loco.

2 Tregelles, Printed Tent of the Cireck Testument, 1'1. 258, 259.

3 Alford's Gireel T'estement on Mtark xvi. 9-90, list ed. vol. i. p. 438.

4 Meyer's Commentury on .lurk, critical notes on rv. 9-20. 
Lord Himself was added at another time, and probably by another hand." 1

Opposed to the views of these distinguished critics are the opinions of other erities of great eminence. Lachmam inserts the passage in his critical New Testament, with the

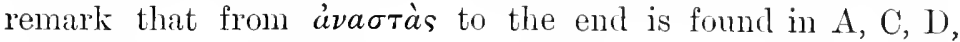
Irenceus, but omitted in B, Eusebius. ${ }^{2}$ Scrivener, perhaps our greatest biblical critic in reeent times, with the possible exceptions of Bishop Lightfoot and Dr. Hort, says: "We engage to defend the anthentieity of this long and important paragraph without the slightest misgiving." 3 And Dean Burgon has written an elaborate work in defence of the passage, in which he gives at great length the external and internal evidences for and against these verses, and claims to have demonstrated their genuineness: "It shall be my endeavour to show, not only that there really is no reason whatever for calling in question the genuineness of this portion of Holy Writ, but also that there exist suffieient reasons for feeling confident that it must be genuine." 4

1. The external evidenee against and for the genuineness of Mark xvi. $9-20$.

External evidenee against its yenuineness. The paragraph is omitted in the two oldest manuseripts, the Vatiean (B) and the Sinaitic (\$). In both, after the words é $\phi \circ \beta o v ̂ \tau o ~ \gamma a ̀ \rho$, comes

1 Westcott, Introduction to the Stuly of the Gospels, p. 309, 1st ed. The passage is also rejected by Westcott and Hort in their critical edition of the Greek New Testument. "Its authorship and its precise date must remain unknown," vol. ii. Notes on Select Readings, p, 81. The passage is also rejected by Archbishop Thomson, Smith's Dictionary of the Bible, vol. ii. p. 239, and by Bishop Lightfoot.

2 Lachmann's Novum Testomentum, vol. i. p. 31t.

3 Scrivener's Introduction to the Study of the N.T. p. 429, 1st ed. The same remark is repeated in his 3 rd edition, 1.583 ; and in the 4 th edition, published after his decease (1894), rol. i. p. 337 .

${ }^{4}$ Burgon, The last verses of the Gospel aceording to St. Mark, p. 1. This is an admirably reasoned work, a masterpiece in biblical criticism. Dr. Scrivener remarks: "Dr. Burgon's hilliant monograph has thrown a stream of light upon the controversy, nor does the joyous tone of his look misbecome one who is conscious of having triumphantly maintained a canse which is very precions to him." Introduction to Biblical Criticism of the N.T. vol. ii. p. 337, 4th edition. 
the subscription. There is, however, some reason to doubt whether these manuseripts should be considered as independent testimonies, or whether they should not rather be regarded as one witness, being, not incleed copies of the same manuseript, but of two manuscripts elosely related to each other, as there is a general agreement in their readings. This is especially the ease if there is any truth in the statement of Tischendorf, that the same seribe who wrote the Codex Vaticanus also transcribed certain pages of the Codex Sinaiticus. The six pages of Codex $s$, which Tischendorf seleets as proofs of this statement, are from Mark xvi. 2 to Luke i. 56, and consequently contain the very portion of Mark's Gospel which includes these verses. So that, if this statement is correct, it follows that in these pages at least we have the testimony only of one witness, namely, the Vatican manuseript. ${ }^{1}$ This is eertainly a witness of great importance, being the oldest extant Greek manuscript of the New Testament. But even this testimony of $B$ is somewhat weakened by the fact that not only is the remainder of the column, where the worls $\dot{\epsilon} \phi o \beta o \hat{\nu} \nu$ ro yà oceur, left blank, but the next columm is also vacant, and as has been remarked, "it is the only vacant column in the whole manuscript; a blank space abundantly sufficient to contain the twelve verses" which are omitted." The only reason that can be assigned for this vacancy is that the scribe of the Vatican had before him a manuscript which containet the verses in dispute, but which he, for some reason, left ont.

The mncial minuseript L, or Codex Regins Parisiensis No. 62, belonging, aceording to Tischendorf, to the eighth century,

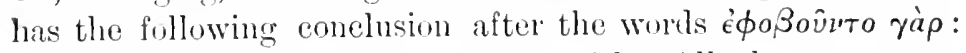
"Something to this effeet is met with: All that was commanded them they immediately rehearsed to Peter and the rest. And after these things from the kast even to the West did Jesus Himself send forth hy their means the holy and incorruptible message of eternal salvation. But this also

1 Serivoner's Introduction, 4th al. vol. ii. 11. 337, note. "At least," he ohserves, "in these leaves, Corl. N, B, make hit one witness, not two."

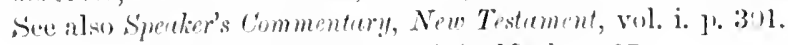

2 Jurgon's Last tertere verses of S't. Murk, 1'. 8. 
is met with after the words, 'For they were afraid,' Now when he was risen early," etc.; then follow the words, vv. $9-20$ as found in the teatus receptus. ${ }^{1}$ Thus there are attached to this manuscript two conclusions, one undoubtedly spurious, the other that which is usually attached to the Greek text.2

Among the cursive manuscripts, Codex 22 concludes with the words $\dot{\epsilon} \phi o \beta o v v \tau o$ yà $\rho$, and then adds in red ink: "In some copies the Gospel is completed at this part, but in many these are also current"; then follow vv. 9-20.3

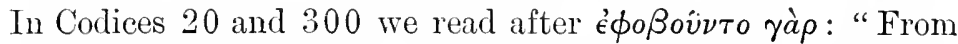
here to the end forms no part of the text in some copies. But in the ancient copies it all forms part of the text." ${ }^{4}$ It has been affirmed by Birch that two cursive manuscripts, 137 and 138 , have the passage marked by an asterisk, as denoting a suspicion of its genuineness; but this point has been carefully examined by Dean Burgon, and the result of his examination is that Codex 137 has a simple cross referring to an annotation, and that Codex 138 has neither cross nor

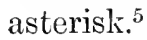

There is hardly any evidence from the versions against the genuineness of this passage. The Codex $\mathrm{k}$, or Codex Bobbiensis of the Old Latin version, now in the National Library of Turin, wants the usual conclusion of Mark's Gospel, and in its place inserts a Latin translation of the spurious ending found in Codex L already given. The verses are omitted in some Old Armenian codices, and one of them in a space between vv. 8 and 9 has the remarkable reading, "Of Ariston, presbyter," as if Ariston were the writer of the verses which follow. To this remarkable reading we shall afterwards advert. The verses are also omitted in the Sinaitic

1 Burgon, pp. 123, 124; Tregelles, Printed Text of the Greel Text, p. 254.

2 This manuscript is supposed to have been one of those used by Stephens $(n)$ in the formation of his Greek Testament. It bears a close resemblance to the Vatican and to the citations of Origen. Scrivener olserves: "It is but carelessly written, and abounds with errors of the ignorant scribe, who was more probably an Egyptian than a native Greek." Vol. i. p. 138.

3 Alford's Greek Testament on Mark xvi. 9.

4 Burgon, p. 118.

5 Burgon, p1. 116, 11 . 
palimpsest of the Syrian version of the Gospels recently discovered $(1892,1893)$ by Mrs. Lewis.

Eusebius, in the fourth century, on whose words great stress has been put by those upposed to the insertion of this passage, was the first to east doubts on its gemmineness. His words are contained in the fragment of a lost work foumd in the Vatican Library, and published by Cardinal Mai in $1825 .^{1}$ They are a reply to a certain Marinus who asked how the statement contained in Mark xvi. 9, that Jesus rose early the first day of the week, conld be reconciled with the statement in Matthew's Gospel, that He rose on the end of the Sabbath, as it began to dawn toward the first day of the week. ${ }^{2}$ To this question Eusebius replies: "Two answers might be given. He who denied the whole passage might say that it is not found in all

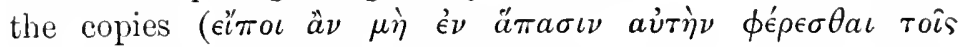

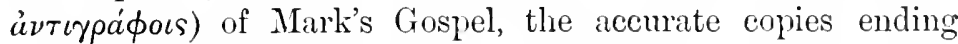
with the words of the young man who appeared to the women, 'Fear not ye! Ye seek Jesus of Nazareth' . . . to which the evangelist adds: 'And when they heard it they fled, and said nothing to any man; for they were afraid.' These words in almost all the copies of Mark's Gospel form the end. What follows which is met with in some but not in all the copies may be regarded as supertluous; especially if they should prove to eontradict the statements of the other evangelists. This one might say for evading and getting rid of a superfluous disenssion. But another, not daring to reject anything which is met with in the text of the Gospels, might say, Here are two readings, and both are to be received; inasmuch as by the faithful this reading is not hell to be genuine rather than that." Although the language is somewhat ambiguous, yet it may be adnitted that Eusebius here asserts that these concluding verses were onitted in almost all the eopies of Mark's Gospel with which he was conversant. This, however, must be regarded as a rhetorieal

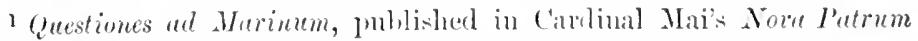
Bibliothere, vol. iv. 117. 25.5-25\%.

2 The whole gitsage is given in Bungon's Last trelve verses of St. Mark, IN. 265, 266, $\Lambda_{\text {II. }}$ I. 
exaggeration, for only a very few manuscripts have come down to us which want these words. Eusebius then here either uses rhetorical language, or perhaps does not express his own opinion, but puts the words into the month of the

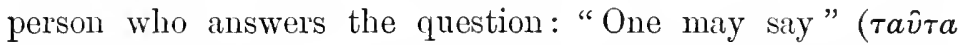
$\mu \grave{\epsilon} \nu$ ôे $\left.\epsilon^{\prime \prime} \pi \circ \iota\right)$ : "This is what a person may say for getting rid of the whole question." The testimony of Jerome is given in his Epistle to Hodibia, but it is only a repetition of the statement of Eusebius; the same difficulty is proposed, and the same solution is given. Similarly Hesychius, bishop of Jerusalem (A.D. 400), refers to the same difficulty, and gives the same answer: he says: "The more accurate copies of Mark's Gospel end with 'For they were afraid'; but in some it is added, 'But when He was risen again,' etc. But this appears to contradict what has been before asserted in Matthew." 2 It is also maintained that there is no reference to this passage in the writings of the early Fathers, whether Latin, as Tertullian and Cyprian, or Greek, as Clemens Alexandrinus and Origen, in their discussion on subjects where they would naturally refer to it. But this argumentum e silentio is very precarious.

II External cvidenee in farour of its genuinencss. With the (exception of $s$ and $B$, the words are contained in all the other uncial manuscripts of this Gospel. ${ }^{3}$ They are found in the Alexandrian manuscript (A), in the Codex Ephræm (C), in the Codex Bezæ (D), and in the other thirteen uncial manuscripts. ${ }^{4}$ Almost all the cursive manuscripts of this Gospel, of which there are six hundred, contain the words in question, cxcept, of course, those which are defective.

The versions are virtually unanimous in their testimony in favour of the retention of the passage. It is found in all the manuscripts of the Old Latin with the exception of the

${ }^{1}$ Ep. 120 ad Hedibiam.

${ }^{2}$ See Burgon, pp. 57-59 ; M'Clellan's New Testament, vol. i. p. 682.

3 "With the exception of the two uncial manuscripts which have just been named," says Dean Burgon, "there is not one codex in existence, uncial or cursive, (and we are acquainted with at least eighteen other uncial and about six hundred cursive copies of this Gospel,) which leaves out the last twelve verses of St. Mark," p. 71.

${ }^{4}$ Namely, E F" G H K M S U V X $\Gamma \Delta \Pi$. 
Codex Bobbiensis ( $\mathrm{k}$ ) already mentioned. It is inserted by Jerome in the Vulgate, thus proving that that Father did not, as some suppose, serionsly call in question its genumeness. It is contained in all the Syriac versions-the Peshito, the Philoxenian Syriac, and the Cureton Syriac, one of the fragments of which contains the last four verses, with the exception of the Syriae manuscript of the Gospels recently found at Mount Sinai. It is eontained in the Armenian version, except in some codices, and in the two Egyptian versions. In short, it is not affirming too much to say that the evidence of the versions is practically unanimous in favour of this section of the Gospel of Mark.

The positive testimonies of the Fathers mitil Euselius are all in favour of the gemuneness of the section. It is a short passage, and consequently is not often referred to. Justin Martyr (A.D. 150) in his first Apology apparently cites Mark xvi. 20: "That which he (David) says, "He shall send to thee the rod of power ont of Jerusalem,' is predictive of the mighty Word which His apostles, going forth from Jerusalem, preached everywhere." ${ }^{1}$ On this, however, we do not lay much stress; for although there is a striking resemblance between these words and the conclusion of Mark's Gospel, there may he some doubt whether Justin actually quotes from it. Much more important is the testimony of Tatian (A.I. 160). The passage is undoubtedly contained in the Diatessaron, as is proved from the Arabic manuscript from Egypt recently brought to light and now translated.2 This demonstrates that the words formed part of Mark's Ciospel towarl the milldle of the second century. So far as we can ascertain, this important testimony of Tatian was mknown to Grieshath, Tischemelorf, Tregelles, Alforet, Meyer, and Westeott and Ifort, when they arriverl at their opinion unfirourable to the gennineness of this passage; and if so, this fact must to some extent invaliblate their conchsion. ${ }^{3}$ Irentus (A.I. 180)

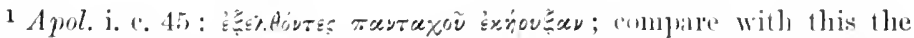

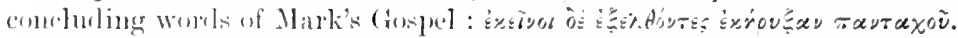

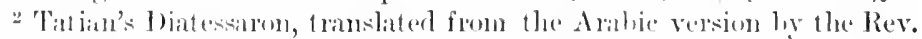

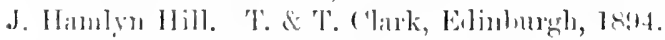

s'lat ian's biatessaron is not referred to by these lintingnished biblical critics. 
has a distinct quotation from Mark xvi. 19: "Toward the conclusion of his Gospel, Mark says: So then, after the Lord Jesus had spoken to them, He was received up into heaven, and sitteth on the right hand of God." 1 So also Hippolytus, a contemporary of Irenæus (A.D 200), quotes vv. 17 and 18 in a fragment of a work concerning spiritual gifts: "Jesus said to them all collectively concerning the gifts given from Him by the Spirit: These signs shall follow them that believe: In My name shall they cast out demons; they shall speak with new tongues; they shall take up serpents; and if they drink any deadly thing, it shall in nowise hurt them; they shall lay hands on the sick, and they shall recover." ${ }^{2}$ And in his treatise against Noetus there is also an apparent reference to this section in Mark's Gospel. "Christ is taken up to heaven, and is set down at the right hand of the Father" (Mark xvi. 19). ${ }^{3}$ The passage is also twice cited in the Apostolic Constitutions, written in the fourth century: "For the Lord says, He that believeth, and is baptized, shall be saved; but he that believeth not shall be damned" (Mark xvi. 16). " "With good reason did He say to all of us together, when we were perfected concerning those gifts which were given from Him by the Spirit: Now these signs shall follow them that have believed in My name; they shall cast out devils, they shall speak with now tongues," etc. (Mark xvi. 17). ${ }^{5}$ The passage is quoted or referred to by Cyril of Jernsalem, Epiphanius, Jerome, Augustine, Chrysostom, and subsequent Fathers.

If 2. The internal cridence against and for the genuineness of Mark xvi. 9-20.

The objectors to the genuineness of this passage generally place the great force of their argument on the internal evidence. Many of them admit that the external evidence is rather favourable than otherwise, but assert that the internal

${ }^{1}$ Irenæus, $A$ dv. Hor. iii. 10. 6: In fine antem Evangelii ait Marens: Et quidem Dominus Jesus, postquam locutus est eis, receptus est in culos, et sedet ad dexteram Dei. Mark xvi. 19.

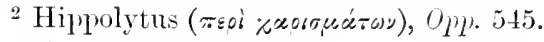

${ }^{3}$ Contra Hor. Noeti, c. 18.

+ Apost. Const. vi. 15.

${ }^{5}$ Ibid. viii. 1. 
evidence is preponderantly unfavourable. "The internal evidence," observes Dean Alford," is, I think, very weiglity against Mark's being the author. No less than twenty-one words and expressions occur in it, and some of them several times, which are never used elsewhere by Mark, whose adherence to his own peculiar phrases is remarkable." 1 The style, it is affirmed, is very different from that of Mark. Insteal of those graphic tonches which impart a vividness to Mark's narrative, and represent the scenes described before the mind's eye, we have a dry summary of events. The particle of transition, evं $\theta \dot{\epsilon} \omega$, forthwith, so constantly used by Mark, and which imparts life to the narrative, is wanting. The phraseology also is not that of Mark. Thus, for example, the first day of the week is called $\pi \rho \omega \tau_{\eta} \eta \sigma a \beta \beta a ́$ тov instead of $\mu$ '́a $\tau \hat{\omega} \nu \sigma a \beta \beta a ́ \tau \omega \nu$ (Mark xvi. 2). Mary Magdalene is introduced as "she out of whom He had cast seven devils," although mentioned a ferv verses before (ver. 1). Jesus is twice called ó кúpros (vv. 19, 20), a title which is not elsewhere found in Mark's Gospel. And the following words and phrases, given by Tregelles, are not found elsewhere in this Gospel: торєúopac

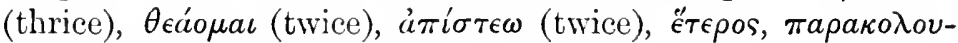

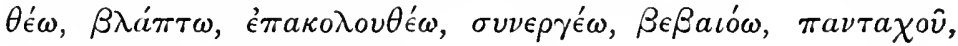

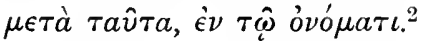

These points are apparently unfavourable; but when closely examined they are not so alverse as they at first appear. The style is not wholly different from that of Mark. The passage is ecrtainly a category of particulars, but still it is not wanting in traces of Mark's graphie style. For example, when Mary came to the apostles to amnounce the appearance of the Lord to her, there is the graphic touch that she found them utterly cast down: "She went and told them that had been with Him, as they mourned and wept" (xvi. 10). So also the unbelief of the disciples at the repeated news of the resurrection of their Lord is recorded only here (xvi. 13). It is true that the favourite transitional particle evं $\theta$ é $\omega$ s

1 Alforl's Greek Testrment, in loco.

2 'Tregelles, l'rinted Tert of the direek Testement, 257. See also Farrar's Mtesseyes of the Buolus, 1.67ll.; Norton, Genuineness of the (iospels, vol. i. P. 219. 
does not occur, but it is also wanting in the twelfth and thirteenth chapters. The expression $\pi \rho \omega \dot{\tau} \eta \sigma a \beta \beta a$ rov instead of $\mu^{\prime} a \tau \hat{\omega} \nu$ $\sigma a \beta \beta a \tau \hat{\omega} \nu$ is only another expression used by the author for the sake of variety. The mention of Mary Magdalene as she out of whom Jesus had cast seven devils, is designed to show the wonderful love and condescension of Christ in appearing first to her. The objection that the title $\dot{o}$ кúpıos is foreign to the diction of Mark, ${ }^{1}$ is of

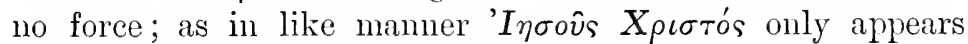
once in his Gospel (Mark i. 1). And although it is true that the phraseology of the section is somewhat different from that of Mark, yet there occur in it expressions which are often found in his Gospel, but rarely in the other Gospels, and which may be considered as words and phrases peculiar to

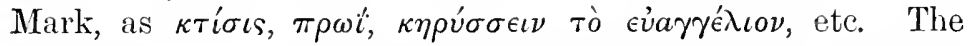
rare word $\sigma \kappa \lambda \eta \rho о к а \rho \delta i a$ (ver. 14) occurs again in Mark's Gospel (x. 5), but is only found once again in the New Testament (Matt. xix. 8).

The extreme improbability of the Gospel having such an abrupt conclusion, if the closing words are omitted, is a strong internal evidence in favour of the genuineness of the section. If the passage is not genuine, the Gospel terminates at the eighth verse with the words $\dot{\epsilon} \phi \circ \beta o v \nu \tau o$ yá $\rho$. There is no mention of the appearance of Christ to His disciples or to the women, no intimation of the astonishing events which followed, no record of the resurrection. Even those who call in question the genuineness of the passage do not suppose that this was the close of the Gospel, but admit that there must have been a conclusion, either actual, which has been lost, or intended, which Mark was prevented writing. "That Mark," says Griesbach, "should have intentionally ended his

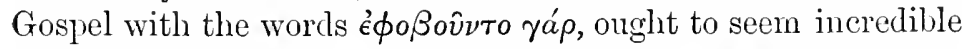
to all." 2 "It would be," says Michaelis, " a wonderful conclusion of a book." ${ }^{3}$ "Few Greek scholars," observes Dr. Abbott, "will be induced to believe that the author of the Second Gospel deliberately chose to end a book on the good

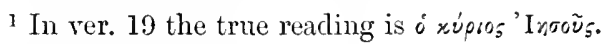

2 Com. Crit. p. 199.

3 Michaelis, Einleitung, p. 1060 ; Marsh's Michaelis, vol. iv. p. 210. 
news of Christ with the words $\dot{\epsilon} \phi o ß o v v \nu \tau$ yáp. From a literary point of view the $\gamma \dot{a} \rho$, and from a moral point of view the $\dot{\epsilon} \phi o \beta o v v \tau o$, make it ahmost incredible that these words represent a deliberate termination assigned by an author to a composition of his own." 1 And even Dr. Hort says: "It is incredible that the evangelist deliberately con-

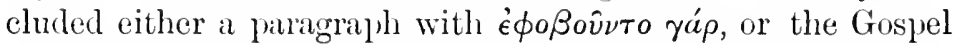
with a petty detail of a secondary event, leaving his narrative hanging in the air." 2

If, then, the Gospel once had a conclusion, actual or intended, we are entitled to ask the objectors to this passage, What has become of it? Two answers have been given to this question. The one, favoured by Norton, ${ }^{3}$ is that Mark was prevented finishing his Gospel; either because Peter, to whom he was indebted for his information, perished at this time in the persecution by Nero (Michaelis), or beeause Mark himself died (Davidson). Both of these are merely gratuitous suppositions. Mark was not so entirely dependent on Peter that he coukd not finish his Gospel without his aid; and it would be most extraordinary that he himself should dic at the very time when he was about to finish his Gospel. The other supposition, favoured by Griesbach and adopted by Alford, ${ }^{4}$ is that the last leaf was torn away. ${ }^{5}$ This is certainly a strange hypothesis, the resorting to which ean only be accounted for by the impossibility of otherwise explaining the fact of such an abrupt conchusion. The Gospel, when written, would be committed to the eustody of some particular Church, and by them it would be most carefully preserved. Surely the supposition is far more reasonable, that the present conchusion of Mark's Gospel is genuine, and was written by the evangelist himself.

1 Encyclopolice Britanniar, article "The Gompls," vol. x. p. 801.

2 Westcoth and Hort's Grek Testument, vol. ii. notes, 1. 46.

${ }^{3}$ Norton's Gemuineness of the Gospels, vol. i. 1'. 221.

4 "The most ponblyle sulposition is that the last leaf of the original Gespel was lon away." - Alforl.

"Two contingeneide," olserves 1)r. Hont, "lave to loe taken into account-either the (bos mel may never lave heen tinislued, on it may have lost its last baf lofore it was multiplied ly tranceription." Westcott and Hort's N.T. Notes, 1. 47. 
This may be the most appropriate place for adverting to a most ingenious hypothesis recently advanced by Mr. Conybeare in the The Expositor, and which has received the support of such distinguished critics as Zahn and Resch. ${ }^{1}$ In an Armenian manuscript found in the patriarchal library of Ećmiadzin, at the foot of Mount Ararat, written about 986, which Mr. Conybeare collated, he found the Gospel of Mark copied ont as far as "For they were afraid" (ver. 8), and between vv. 8 and 9 the words Ariston Eritzon, equivalent

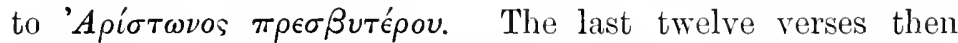
follow, written in the same hand. From this he inferred that it is here affirmed that these last verses were written, not by Mark, but by the Presbyter Ariston. Resch and Sanday suppose that by Ariston is here meant Ariston of Pella, otherwise known to us, who lived about A.D. 140-150; but Conybeare and Zahn think that this is too late to permit of the passage being so generally inserted in the manuscripts and quoted by Tatian and Irenæus. Mr. Conybeare therefore supposes that the person meant is Aristion, the name being wrongly spelt, one of the disciples of the Lord, from whom Papias, according to Eusebins, ${ }^{2}$ derived his traditions. According to Conybeare, the same mistake in spelling occurs in the Armenian version of Eusebius, where the name Ariston occurs for Aristion. Hence it has been inferred that the last verses of Mark's Gospel were taken from the lost work of Papias, and ultimately from the oral tradition of Aristion. It has been supposed that some one, wishing to attach a befitting conclusion to the Gospel, incorporated an extract from the work of Papias containing a tradition of the presbyter Aristion. This hypothesis is most ingenious, and fully accounts for all the anomalies of the passage; and is also in accordance with the opinion of those critics who assert that it is some ancient fragment inserted for the completion of the Gospel (Alford, Hort, Tregelles, Bishop Lightfoot, Archbishop Thomson, etc.). It can, however, hardly be adopted. It occurs only in an obscure Armenian

1 Erpositor for October 1893, 1p. 241-254; and for Septemluer 1894 , pp. 219-232.

${ }^{2}$ Hist. Eccl. iii. 39. 
mamuscript of no anthority, and is destitute of all other confirmation.

Such, then, is the evidence for and against the genumeness of Mark xvi. 9-20. The external evidence is strongly in its favour. The whole external evidence against the passage amounts to its omission in the Vatican manuseript, to statements annexed to the conclusion of the Gospel in Codex $\mathrm{L}$ and in three unimportant cursive MSS., and to an exaggrerated assertion of Eusebius, which has been followed by Jerome and Hesychius. The Sinaitic manuseript $x$ is considered as the same testimony as the Vatican: or if this be ealled in question, then there are only three uncial manuseripts (N $\mathrm{B} \mathrm{L}^{1}$ ) against the passage. On the other hand, with these exceptions, all the Greek manuseripts, both uncial and cursive, all the Fathers who refer to the passage, and all the versions except the recently discovered Sinaitic Syriac, are in its favour. It may be that the internal evidence is against its retention, though this is a matter of opinion which may be and has been questioned. But in all critical questions, unless there are decided reasons to the contrary, which in this case do not exist, the internal evidence must yield to the external. With regard to the external evidence, we have facts to go upon, whereas the internal evilence is almost purely subjective. As Dr. Hort himself observes in his eliborate examination of this passage: "We do not think it necessary to examine in detail the intrinsic evidence supposed to be furnished by comparison of the vocabulary and style of vv. 9-20 with the unquestioned parts of the Gospel. Much of what has been urged on both sides is, in our judgment, trivial and intangible." 2 The internal evidence against it is certainly not so strong or so clear as to counterbalince the extemal evildnce for it. We therefore feel construined to come to the conclusion that Mark xvi. 9-20 is a genuine portion of the Gospel. We are perfectly aware that in arring at this eonclusion we may be acensed of mulue confidence in opposing the views of crities of such pre-eminence as Tischendorf, Tregelles, and Westeott and Ilort, who, in their eritical

2 Even in $\mathrm{T}_{\text {the }}$ linsiage is inserted ats an alternative reading.

"The Circel Nem Testement Notes, 1. 48. 
editions of the New Testament, all reject this passage. But they had not the data which we now possess in the important testimony of Tatian, and the authority of these great names does not destroy our private julgment, or cause us to relinquish our convictions; nor are we unsupported in this conclusion by other eminent critics, such as Scrivener ${ }^{1}$ and Burgon.

The opinions of biblical critics are much divided, although we at once admit that the preponderance of authority, though not so great as is generally supposed, is mufavourable to the genuineness of this passage. Wetstein, Storr, Mill, Grotius, Bengel, Scholz, Kumoel, ${ }^{2}$ De Wette, Hug, Bleek, ${ }^{3}$ Gnericke, Schleiermacher, Principal Campbell of Aberdeen, ${ }^{4}$ Ebrard, Hilgenfeld, Keil, Stier, Lange, Scrivener, Burgon, Bishop Wordsworth, Dean Bickersteth, Canon Cook, ${ }^{5}$ M'Clellan, Edersheim, S.lmon, ${ }^{6}$ Morison, Wace, and Bishop Ellicott declare in favour of its genuineness. Whereas Michaelis, Griesbach, Credner, Wieseler, Ewald, Norton, ${ }^{7}$ Tischendorf, Tregelles, Meyer, Alford, Westcott and Hort, Klostermann, Bishop Lightfoot, ${ }^{8}$ Archbishop Thomson, ${ }^{9}$ Davidson, Warfield, Farrar, Abbott, Zahn, Resch, and Holtzmamn decide against its genumeness.

I Scrivener thus states the result at which he arrives: "All opposition to the anthenticity of the paragraph resolves itself into the allegation of Euselins and the testimony of $\times B$. Let us accord to these the weight which is their due; but against their verdict we can appeal to a vast body of ecclesiastical evidence reaching back to the earlier part of the second century ; to nearly all the versions; and to all extant mannscripts excepting two, of which one is doubtful." Introduction to the Criticism of the N.T. vol. ii. p. 34t, 4th edition.

2 Kuinoel, Novi Testementi Libri Historici, in loco.

${ }^{3}$ Bleek, Introáuction to N.T. vol. i. 1). 312, Eng. trans.

${ }^{4}$ Camplell, On the Gospels, vol. iii. p. 178.

5 Cook's Revised Version of the first three Gospels, pp. 120-125.

"Salmon's Introduction to the N.T. 1'P. 190-193, 1st ed. 1885.

' Norton's Genuineness of the Gospels, vol. i. pp. $217 \mathrm{ft}$.

${ }^{8}$ Lightfoot ascribes it to "that knot of early disciples who gathered about St. John." Revision of the N.T. 1. 28.

9 He says: "It is probable that this section is from a different hand, but was amexed to the Gospels soon after the time of the apostles." Suith's Bible Dictionary, rol. ii. p. 239. 


\section{Vil. Thue axd Place of Writisg.}

The date of this Gospel is a point of great dubiety, on which the most contradictory opinions prevail; indeed, it is a point on which we have not data sufficient to warrant any definite or even proximate decision. There are eonflicting testimonies with regard to it, and it is interwoven with other questions, as, for example, with the synoptic problem on the somrees of the Synopties. Whilst external evidenee is defective, there are in the Gospel itself few indications of time.

The opinions of the Fathers are here not in agreement. Some assert that Mark wrote his Gospel after, and others before, the death of Peter. Irenens, in a passage alrealy quoted, asserts that it was written after the death of Peter and Paul. "Matthew published his Gospel among the Hebrews in their own langnage, while Peter and Panl were preaehing and laying the foundations of the Church at Rome.

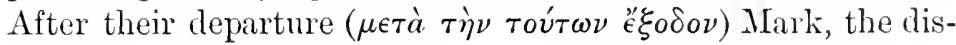
eiple and interpreter of Peter, also transmitted to us in writing those things which Peter had preached." ${ }^{1}$ Some, as Mill, Kuinoel, and others, suppose that by ' ' $_{0} \delta \delta_{\nu}$ is meant departure, as is the evident meaning of the word in Heb. xi. 22-after the departure of Peter and Paul from Rome; but such a statement would be useless and insignificant. Others, as Hug, Credner, Guerieke, and Ebrard, interpret the expression as denoting death-after the decease of Peter and Paul, that is, after A.D. 64, the year of the perseention by Nero, when it is supposed that these two apostles were put to death; and this seems to be the usual scriptural meaning of the word, and is an important statement. Some comect with this statement the words of Peter in his Second Epistle: "I will endeavom that ye may be able after my decease (the same word $\left.\varkappa^{\prime} \xi o \delta o \nu\right)$ to have these things always in remembrance" (2 Pet. $\mathrm{i}$. 15). "Here," olsserves I'rofessor Warfield, "is a promise by I'eter that he will see to it that his readers shall be in a position after his death to have his teaching always in remembrance;

${ }^{1}$ Irentrus, Alle. Mur. iii. 1. 1 ; Eusehins, Hist. Eerl. v. 8.

2 Luke x. $21 ; 2$ Pet. i. 1 . 
and in this he has special reference to the facts of the life of Christ, witnessed by him, as is proved by the pupose which he expresses for so arranging, namely, that they may know that they have not followed cmnningly devised fables, but facts antoptically witnessed. Surely this seems to promise a Gospel." 1 The truth of this statement of Irenæus is, however, extremely doubtful. It is uncertain that Peter and Panl were together in Rome: they certainly did not lay the foundation of the Church of Rome; that Church was founded years before their arrival, as is evident from the fact that Paul at an earlier period wrote an Epistle to the Romans, and that on his arrival at Rome he found a Christian Church already existing. The implied coincidence of the time of their martyrdom is legendary.

This statement of Irenæus is counterbalanced by that of Clemens Alexandrinus, who informs us that Mark published his Gospel, not after the death of Peter, but in his lifetime, and with his knowledge and approval. Thus in a passage quoted by Ensebins, Clement says: "As Peter had preached the word publicly at Rome, and declared the Gospel by the Spirit, many that were present requested that Mark, who had followed him for a long time and remembered his sayings, should write them out. And having composed the Gospel, he gave it to those who had requested it. When Peter learned this, he neither directly forbade nor encouraged it." 2 The same opinion was adopted by Ensebius and Jerome. Jerome speaks as if Peter had actually dictated the Gospel to Mark.

These testimonies contradict each other; Irenæus asserting that Mark wrote his Gospel after the death of Peter, and Clemens Alexandrinus that it was written before that event. All critics, except those belonging to the Tiibingen school, agree that this Gospel was written before the destruction of Jerusalem, that is, before A.D. 70 . There is no reference in it to that event: on the contrary, there are in the prediction of our Lord indications that it had not yet occurred (Mark xiii. 13, 24, $30,33)$. The catastrophe was impending, but had not taken place. There were the symptoms of the coming storm, but it

${ }^{1}$ Quoted in Kerr's Introduction to N. T. Study, p. 37.

2 Eusebius, Hist. Eccl. vi. 14. 
had not burst upon the land. So, also, there is an intimation that this Gospel was written after the dispersion of the apostles and after the diffusion of Christianity beyond Jerusalem, that is, after A.D. 44 . "And they (the disciples) went forth, and preached everywhere, the Lord working with them, and confirming the word by the signs that followed" (xvi. 20). Thus, then, between these two limits, A.D. 44 and A.D. 70, the composition of this Gospel is to be placed.

If Mark's Gospel is the earliest, constituting one of the chief sources of the other two, for which opinion there are plausible reasons, then it must have been written before A.D. 55, the date which we found most probable to ascribe to the Gospel of Matthew. But, if Mark's Gospel is not the earliest, if, as many critics suppose, the Gospel of Matthew preceded it, then a later date must be adopted. Several objections have been made to the earlier date. If, it has been said, the Gospel of Mark was written before Paul's first Roman imprisonment (A.D. 63), P'aul in his Epistle to the Colossians, written at that time, would have mentioned Mark by a much higher designation than merely as the cousin of Barnabas (Col. iv. 10); he would have alluded to lim as the author of the Gospel. But this is a mere conjectural statement; it proceeds on the doubtful supposition that Mark, the disciple of I'eter, the author of the Gospel, was the same as Mark the eompanion of Paul and the cousin of Barmabas: and, besides, the argumentum e silentio is always precarious. It is also affirmed that this early date contradicts the testimonies of Irenieus and Clemens Alexandrinus; but we have seen that their testimonies are conflieting, and cannot be relied upon for fixing a precise date for the writing of Mark.

Aceordingly, no arguments can be drawn from the statements of the Fathers with regard to the date of the Gospel of Mark; and the indications of time in the Gospel itself are slight and ambignous. The opinions of erities are very diverse, varying from A.D. 40 to A.D. 170. The Paschal Chroniele and Hesyehins fix on A.I. 40; Eusebins in his Chronicon gives the third year of the reign of Claudius, A.D. 43; Jirks fixes on A.1). 48 ; Schenkel, on A.1). 45-58; 
Hitzig, on A.D. 55-57; Lardner, on A.D. 64; Gnericke, on A.D. 67 or 68 ; Alford, "after the dispersion or even the death of the apostles, and before the destruction of Jerusalem by the Roman armies under Titus, in the year A.D. 70." The critics belonging to the Tuibingen school generally place the composition of the Gospel after the destruction of Jerusalem; Hilgenfeld, about A.D. 81 ; Köstlin, about A.D. 110 ; Keim, about A.D. 115-120 ; Davidson, in the last edition of his Introduction, about A.D. 120; and Banr himself, abont A.D. $130-170$.

The place of composition has been as much disputed as the time. The most common opinion is that this was Rome. This is the uniform assertion of the Fathers-Irenæus, Clemens Álexandrinus, Eusebius, Jerome, and Epiphanius. It is stated in the subscription to several cursive manuscripts. In the Peshito there is the following subscription: "Here ends the holy Gospcl, the announcement of Mark, which he spoke and preached at Rome in the Roman language." The same opinion is adopted by most recent critics. The fact that the Gospel was written for Gentile readers, and the Latinisms which are found in it, are favourable to this supposition. An argument has been drawn from Rom. xvi. 13, where it is written: "Salute Rufus, the chosen in the Lord." In the Gospel, Simon the Cyrenian, who carried the cross of Jesus, is called the father of Alexander and Rufus (Mark xv. 21). Now, if this Rufus who, being thus saluted in the Epistle to the Romans, was evidently an important member of the Church of Rome, was the son of Simon the Cyrenian, it was natural that Mark, when writing his Gospel at Rome, should allude to him. To this supposition there is, however, a formidable objection. If Mark wrote his Gospel at Rome and for the Romans, there was not sufficient time for its transmission to Palestine, in order to its being used by Matthew at such an early period as A.D. $55 .^{1}$

Other places have been fixed on. Chrysostom mentions a tradition which fixes on Alexandria as the place of composition. "Mark is said ( $\left.\lambda_{\text {é }} \in \tau a \iota\right)$ to have composed his Gospel in Egypt at the solicitation of his friends there." 2

1 See supra, p. 140.

${ }^{2}$ Chrysostom, Hom. in Matt. i. 
This statement is also found in some cursive manuscripts to

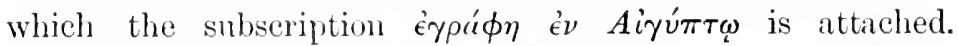
Some (Simon, Lardner, Eichhorn, Michaelis) suppose a double place of composition: that the Gospel was written partly in Rome and partly in Alexandria. Jerome says that Mark, taking the Gospel with him which he had composed, went into Egypt. Michaelis supposes that Mark wrote his Gospel at liome, but finished it at Alexandria, which accounts for the difference which exists between Mark xvi. 9-20 and the rest of the Gospel. ${ }^{2}$ There is no ground for this supposition: it is mentioned by none of the Alexandrian Fathers.

Storr ${ }^{3}$ conjectures Antioch to be the place of composition, because Mark was residing there, near the seat of apostolic tradition, and in contact with the (rentile converts. The Chureh of Antioch was also visited by l'eter (Gal. ii. 11), whose companion and interpreter Mark was. Stor' also enforces his argument by the combination of Acts xi. 19, 20 and Mark xv. 21. In the Acts we learn that men of Cyrene came to Antioch: in the Gospel we are told that Simon, the father of Alexander and Iinfus, who bore the cross, was a Cyrenian. He thinks it probable that Alexander and Rufus were among the men of Cyrene who came to Antioch.

More plansible is the supposition of Birks, that Ciesarea was the place of writing. "The second Cospel," he observes, "was written by John Mark about the year 48 , and probably at Ciesarea, with a reference not only to Jewish believers, but to Centile lioman converts, who wouk have multiplied there in seven or eight years from the conversion of Connelins." t This would alford Mattlew rasy access to the Gospel of Nark, and that at an early period. Mark's connection witl l'eter may have been, not in fiome, lant in Palestine.

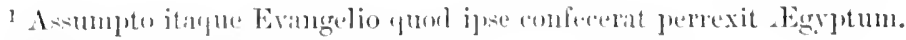

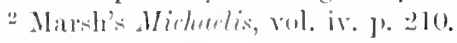

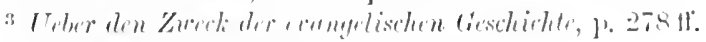

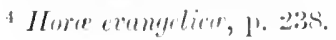




\section{Contents of the Gospel.}

This Gospel may be conveniently divided into three parts.

1. The preparation for the ministry, i. 1-13, containing the ministry of John the Baptist, the baptism of Jesus, and the temptation in the wilderness.

2. The ministry in Galilee, i. 14-x. 42, forming the main part of the ministry, containing the call of the apostles, an account of the miracles of Christ, a series of parables, the mission of the apostles, the death of the Baptist, the twofold miraculons feeding of the multitude, the confession by the diseiples of the Messiahship of Jesus, the Transfiguration, a minute account of the cure of the demoniac boy, the blessing pronomeed on little children, the rich young ruler, the cure of blind Bartimæens.

3. The close of the ministry at Jerusalem, xi. 1-xvi. 20, containing the triumphal entrance into Jerusalem, the retirement to Bethany, the parable of the wicked husbandmen, the prediction of the destruction of Jerusalem, the partaking of the Passover and the institution of the Lord's Supper, the agony at Gethsemane, the double trial before Caiaphas and Pilate, the crncifixion, the burial, the women at the sepulchre, the resurrection.

There is little that is peculiar to Mark, but there are many additions to the narrative. Many of these we have already noted when considering its vividness and its graphic tonches. ${ }^{1}$ It is from Mark that we learn that Jesus Himself was a carpenter; that those who were cured, although told to tell the miracles to none, yet blazed them abroad; that the reason why His friends wished to lay hold of Him was because they thought that $\mathrm{He}$ was beside Hinself; that Jesus was repeatedly moved with indignation at the perversity of His hearers; and that it was Peter, James, John, and Andrew who asked him abont the destruction of Jernsalem.

No fewer than eighteen miracles are narrated in Mark's Gospel. It is the record, not so much of the discourses of Jesus, as of His mighty works. The miracles recorted are,

$$
1 \text { See supra, 1. } 185 .
$$


the cure of the man with an unclean spirit in the synagogue of Capernaum, i. 23-2S; the cure of Simon's wife's mother, i. 30,31 ; the eleansing of the leper, i. $40-45$; the healing of the paralytie man, ii. 1-12; the enre of the man with the withered hand, iii. 1-5; the stilling of the storm, iv. 35-41; the cure of the Gadarene demoniac, v. 1-20; the healing of the woman with the issue of blood, v. 25-34; the raising of the danghter of Jairus, v. 35-43; the feeding of the five thousand, vi. 30-44; the walking on the lake, vi. $45-52$; the eure of the daughter of the Syrophenieian woman, vii. 24-30; the healing of the deaf mute, recorded only by Mark, vii. 31-37; the feeding of the four thousand, viii. 1-9; the gradual cure of the blind man at Bethsaida, recorded only by Mark, viii. $22-26$; the eure of the epileptic boy, ix. 17-29; the eure of blind Bartimeus, x. 46-52; and the withering of the fig tree, xi. 12-14.

On the other hand, only four parables are recorded by Mark: the Sower, iv. 3-8; the Seed growing gradually, peculiar to Mark, iv. 26-29; the Mustard Seed, iv. 30-32; and the Vineyard and the Ifusbandmen, xii. 1-11. 


\section{THE GOSPEL OF LUKE.}

Literature.-The principal commentaries and dissertations on the Gospel of Luke are those of Schleiermacher, Ueber die Schriften des Lulias kritiseher Versuch (Berlin, 1817), translated by Bishop Thirlwall, with a valuable introduction (London, 1825); Olshausen (1837, English translation, 1863); De Wette (3rd ed. Leipsic, 1846); Trollope, Commentary on St. Luke's Gospel (London, 1847); Ewald (Göttingen, 1850); Meyer (1st ed. Göttingen, 1860, 6th ed. by Weiss, 1878, translated by the Rev. Robert Wallis, Edinburgh, 1880); Grimm, Die Einheit des Lukasevangelium (Regensburg, 1863); Oosterzee in Lange's Bibelwerk (3rd ed. Bielefeld, 1877), translated by Dr. Schaff (New York, 1866); Van Doren, Suggestive Commentary on St. Luke (Loudon, 1868); Godet (Nenchatel, 1871, translated Edinburgh, 1875); Bishop Jones in the Speaker's Commentary (London, 1875); Alford in his Greck Testament, last edition (London, 1894); Dean Plumptre in Bishop Ellicott's Commentary (1879); Farrar on Luke in the Cambridge Bible for Schools (London, 1882); Riddle in International Commentary (New York, 1882); Dean Spence in Pulpit Commentary (London, 1889); Dr. Colin Campbell, Critical Studies in St. Lutke's Gospel (Edinburgh, 1890).

\section{Genuineness of the Gospel.}

The genuineness of the Gospel of Luke is sufficiently attested. It is true that we cannot here appeal to the Apostolic Fathers, as this Gospel was the latest written of the Synoptic Gospels, and as it is difficult to determine whether 
the citations adduced are taken from it or from the Gospel of Matthew. ${ }^{1}$ It has been affirmed that the Gospel of Luke is quoted by laul in his First Epistle to Timothy: "For the seripture saith ( $\lambda \epsilon^{\prime} \gamma \in \iota$ i $\left.\gamma \rho a \phi \eta^{\prime}\right)$, Thou shalt not muzzle the ox when he treadeth out the corn. And, The labourer is worthy of his lime" (1 Tim. v. 18). The last clause of the verse is only to be found in Luke's Gospel, where the very same

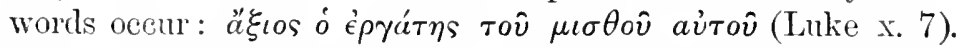
There is nothing incredible in this supposition, eonsidering the close comnection between Luke and Paul, and the probability that the Gospel of Luke was written before the First Epistle to Timothy ; but we hardly think that this Gospel at so early a period wonld be consiclered as seripture ( $\left.i \gamma \rho a \phi \eta^{\prime}\right)$. Marcion. (A.D. 140) is perhaps the earliest witness to the Gospel of Luke. Marcion's Gospel, as we shall afterwards see, was merely a mutilated form of Luke's, and he was living when Justin Martyr wrote his Apologies. "There is," says Justin, "Marcion, a man of I'ontus, who is even at this day alive, and teaching his disciples to believe in some other god greater than the Creator:" 2 Allowing time for the diffusion of his opinions, the Gospel of Marcion cannot be placed later than ten years before the time of Justin. The distinct references of Justin Martyr himself (A.D. 150) to the Gospel of Luke are very numerous. He does not indeed mention the name of Luke, but his citations from the Gospel are ummistakable. The following are the principal quotations: "The Virgin Mary receiverl faith and joy, when the angel Gabriel ammomeed the good tirlings to her that the Spinit of the Lord would come upm her." "3 "On the occasion of the first census which was taken in Judar under Cyrenius, Joseph went up from Nazalreth, where he dwelt, to Bethlehem, to which he belonged, to the enrolled ; for his family was of the tribe of Judah, which then inhalited that region." 4 "Jesus sail to His disciples, I give unto you power to tread on serpents, and

'In Charterin' l'tenmicit", testimonies ane given from l3analas, Ep. xiv. 1; Clement of firme, 1 Ep. xiii. 2, xlvi. 8, lix. 3; Hermat, Mand. v.

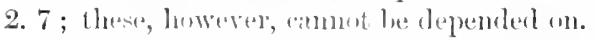

2 Justin, Apol. i. $26 . \quad$ B Dielog. c. Trypho, ch. c.
Thid. ch. laxinit. 
scorpions, and on all the might of the enemy" (Luke $x$. 19). " "In the Memoirs, which were composed by His apostles and those who followed them, it is recorded that His sweat fell down like drops of blood while $\mathrm{He}$ prayed, saying, If it be possible, let this cup pass" (Luke xxii. 42). ${ }^{2}$ "When Christ was giving up His spirit on the cross, He said, 'Father, into Thy hands I commend My spirit,' as I have learned from the Memoirs" (Luke xxiii. 46). ${ }^{3} \quad$ Tatian (A.D. 160) included Luke's Gospel in his Diatessaron, a complete copy of which has recently been discovered. In the Muratorian canon (A.D. 170) the Gospel of Luke is thus mentioned: "The third Gospel is according to Luke. Luke, a physician, whom Paul after the ascension of Christ had chosen as a companion of his journey, wrote this in his own name and according to his own judgment; yet he had not himself seen the Lord in the flesh. Carrying his narrative as far back as he could obtain information, he began from the birth of John." 4 In the Epistle of the Churches of Viemne and Lyons (A.D. 177) there is a reference to Luke's Gospel. "His (Vettius Epagathus) was so consistent a life, that although young he had obtained a reputation equal to that of the elder Zacharias, for he walked in all the commandments and ordinances of the Lord blameless" (Lnke i. 6). ${ }^{5}$ Celsus, who is generally supposed to have lived about A.D. 178, refers to Luke's Gospel, when he adverts to the genealogy of Christ being traced up to Adam. ${ }^{6}$ The first Father who mentions Luke as the author of the third Gospel is Irenrus (A.D. 180). "Luke, the follower and the disciple of the apostles, referring to Zacharias and Elizabeth, from whom, according to promise, John was born, says: 'And they were both righteous before God, walking in all the commandments and ordinances of the Lord blameless." "7 And again, "Now, if any man set Luke aside, as one who did not know the truth, he will manifestly reject that Gospel of which he claims to be a disciple." 8 Irenæus quotes the Gospel of Luke abont eighty times. It is needless to pursue

${ }^{1}$ Dialog. c. Trypho, ch. lxxvi.

${ }^{3}$ Ibid. ch. ev.

5 Eusebius, Hist. Eccl. v. 1.

‘ Irenæus, Adv. Hor. iii. 10. 1.
2 Ibid. ch. ciii.

4 Tregelles, Codex Muratorius.

${ }^{6}$ Origen, Contra Celsum, ii. 32.

8 Ibid. iii. 14. 3. 
the subject further, for after this there is no doubt or question about Luke's authorship of the third Gospel. ${ }^{1}$

Another distinct line of argument is drawn from the relation of the third Gospel to the Acts of the Apostles. These writings profess to have the same anthor. In the Acts the writer alludes to his former treatise. Both works are addressed or dedieated to a certain Theophilus (Acts i. 1; Luke i. 3). This identity of authorship was never called in question by the early Church, and in modern times has been admitted by seholars of all shades of opinion. Dr. Davidson mentions no less than forty-seven terms which oceur in both works, but nowhere else in the New Testament. ${ }^{2}$ De Wette observes: "It is certain that the writer of the Acts is the anthor of the third Gospel, and his peculiarity of style remains the same in both works, and in the Acts of the Apostles from the beginning to the end." 3 And so also Zeller remarks: "The identity of the author of the two writings is raised to such a height of probability that we have every reason to consider it as historically proved." 4 Admitting this identity of authorship, it follows that the whole series of testimonies in favour of the Acts can also be adduced in favour of the genuineness of the third Gospel. Now the testimonies for the Acts are strong and numerons. It is quoted or referred to by Polycarp in his Epistle to the Philippians, ${ }^{5}$ in the Epistle to the Churches of Lyons and Vienne, ${ }^{6}$ by Irenreus, ${ }^{7}$ Clemens Alexandrinus, ${ }^{8}$ Tertullian, ${ }^{9}$ Origen, ${ }^{10}$ and subsequent Fathers. Eusebius places both the Gospel of Luke and the Acts among those books which are universally acknowledged.1"

1 Luke's (romple is also frequently quoted in the Clementine Homilies (A.D. 160-17()).

2Davidson's Introluction to the N.T. vol. ii. 8. See also Davidson's Introduction to the Study of the N.T. rol. ii. 1. 151, 3rd ed,, and Zeller's Apostelyeschichte, I']. 414-425.

${ }^{3} \mathrm{De}$ Wette's A postelyeschichte, 1. 10.

4 Zeller's Acts of the Apostles, translation, vol. ii. 213; A postelyeschichte, 1. 442 .

\footnotetext{
5 Ep. ad Mhitimp. 'h. i.

7 Ade. Morr. iii. 14. 1.

9 Jee Jejunits, ch. $x$.

11 Mlid. iii. 4.
}
"Enduhine, Mist. Eich r. 1
s Stromute, v. 12.
10 Eusetinu, Mist. Erel. vi. 25.


Olshausen has good reason for the assertion: "In the primitive Church there was no opposition either to Luke's Gospel or to the Acts of the Apostles." 1

In recent times the Gospel of Luke has been more or less disputed, especially by Eichhorn, who supposed it to be an enlargement of the Gospel of Marcion; by those critics belonging to the early Tiibingen school who placed the time of its composition about the middle of the second century; and by many of those theologians who have adopted the so-called twofold docmmentary hypothesis concerning the origin of the Synoptic Gospels. There have also been special objections adduced against the genuineness of this Gospel, as, for example, the apparently mythical account of the birth of Christ and its supposed discrepancy with the account given by Matthew, a subject which has already been discnssed ${ }^{2}$ the apparent contradiction between the genealogies of Christ given by Matthew and Luke, which is reserved for a separate dissertation; and the supposed erroneous historical statement concerning the enrolment made by Cyrenius, governor of Syria (Lnke ii. 1), which will be considered when we treat of the chronology of the Gospels.

The chief, or at least the most noteworthy, objection brought against the genuineness of Luke's Gospel is its relation to the Gospel of Marcion, of which several critics consider that it is merely an amplification. On account of its importance and the interest comected with it, we shall examine this subject in detail. ${ }^{3}$

Marcion, one of the most notorions, and in several

1 Olshansen, On the Gospel and the Acts, vol. i. p. xli.

2 See supra, pl. $135 \mathrm{ff}$.

${ }^{3}$ The elief works on the relation of Marcion's Gospel to that of Luke, are Hahn's Evangelium Marcion, contained in the Codex Apocryphus N.T. of Thilo, pp. 401-486 (Leipsie, 1833); Ritschl's Das Evangelium Marcions und das kunonische Evangelium Lukus (Tuibingen,' 1846); Volkmar, Das Evangelium Marcions (Leipsie, 1852); Rönsch, Das Nene Testamentum Tertullian, 1871 ; Baring Gould, Lost and Hostile Gospels, 11. 235-277 (London, 1874); Hill's Marcion's Gospel (Guernsey, 1893). The subject is also more or less discussed in Bleek's Introduction to the N.T. vol. i. P1. 138-154; in an elaborate article on Marcion, by Professor Salmon, in Smith's Dictionary of Christian Biography; in Professor Sanday's Gospels of the Second Century; in an article on Gnosis in Herzog's Retl-Encyclopiddie, 
respects one of the most interesting of the early hereties, was a contemporary of Justin Martyr, and wrote about A.D. 140. He was a native of Sinope, in the provinee of Pontus, of which town his father was bishop. A Christian by birth, he received a thorough Christian education, as is proved by his writings. Perplexed with the existence of evil under the govermment of a good and holy God of infinite power and wisclom, he fell into heresy, and became a disciple of the Syrian Gnostic Cerdo, whose system he dereloped. "Cerdo," says Irenæus, "taught that the God proclaimed by the law and the prophets was not the Father of our Lord Jesus Christ. The former was known, the latter unknown; the one was righteous, the other benevolent. Mareion of Pontus succeeded him, and developed his doctrine." ${ }^{1}$ About A.D. 140 he followed Cerdo to Rome, where he was exeommunicated on account of his erroneous opinions, and in consequence formed a sect of his own. Irenæus informs us that he met with Polycarp at Rome, and, wishing to procure the recognition of that Father, asked him, Dost thou know me? to whom Polycarp replied, I recognise thee as the firstborn of Satan. ${ }^{2}$ There does not appear to have been anything immoral in his teaching, nor, so far as appears, in his conduct. ${ }^{3}$ Unlike many of the early heretics, his doetrine was moral; he even carried asceticism to an unwarrantable extent, not only inculcating abstinence from the use of wine and animal food, except fish, but forbidding his disciples to marry. In the early centuries Mareionism was diffused throughout the Christian Church by reason of its plausibility and the high morality and self-denial which it ineuleated. There was a regular Church formed, with its bishops and presbyters. Epiphanius tells us that besides Rome, where it was at first promulgated, it spread into Egypt, Palestine, Arabia, Syria, Cyprus, and I'ersia. It gradually disappeared in the fourth century, owing to the rise and growth of Manichitanism, a

2nd erl. vol. v. l'l. 231-236, lỵ Jacobi; and in Hannack's Quellentiritito des Crnosticismus.

1 Irencus, Adv. Horr. i. 27. 1.

2 Ibid. iii. 3. 4.

3 The clarge of youthinl incontinence linomght against him is not confirmed ly Ireneus or Tertullim. 
system which it closely resembled, and on account of the repressive measures of Constantine and his successors.

Marcion is generally reckoned anong the earliest of the Gnostic heretics. And certainly many of his doctrines, such as the difference between the supreme God and the Creator, and the docetic nature of Christ, are tenets of Gnosticism. But in his system he does not recognise the Gnostic æons, as the connecting links between the supreme God and the world; nor is there any mixture of heathen philosophy and Oriental speculation, as is the case with all other Gnostic systems. ${ }^{1}$ He contemplated religion from a Christian standpoint. He asserted that the evil which was in the world could not possibly have arisen under the government of a good God; and that consequently there was a difference between God the Creator of the world, the Demiurge

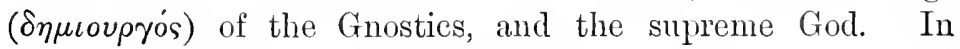
short, he taught that there were two Gods. The Creator was an inferior being to the God of the Gospel, but not, as some of the Gnostics taught, an evil principle. His inferiority consisted in defect; He was limited in power and knowledge, and even goodness. ${ }^{2}$ Hence there was a certain difference, often amounting to antagonism, between the Old Testament and the New. The God of the Old Testament was the Creator, whilst the God of the New Testament was the supreme God; the God of the Old Testament was the God of justice, the God of the New Testament was the God of love. ${ }^{3} \quad$ The law was opposed to the Gospel ; the prophets

1 As Mansel observes: "Marcion is the least Gnostic of all the Gnostics." The Gnostic Heresies, p. 218. "Marcion," says Harnack, "put all emphasis on faith, not on Gnosis." History of Dogma, vol. i. p. 266.

${ }^{2}$ For these tenets of Marcion, see the account of Marcion and his doctrines in Mansel's Gnostic Heresy, lect. xiii.; Salmon's article on Marcion in Smith's Dictionary of Christian Biography. "Marcion," says Irenæus, "advanced the most daring blasphemy against Him who is proclaimed as God by the law and the prophets, declaring Him to be the author of evils, to delight in war, to be infirm of purpose, and even to be contrary to Himself." Adv. Hor. i. 27. 2.

3 Thus he observes: "'Thou shall love thy neighbour and hate thine enemy', was the command of the just God; 'Love thine enemies,' was the law of the good God. 'An eye for an eye and a tooth for a tooth,' was the retributive law of the just God; 'If any smite thee on the right 
of the Old Testament were not the inspired servants of the supreme God, but the servants of the Demiurge. The supreme God was unknown until Christ revealed Him: "No man has known the Father but the Son, and he to whom the Son will reveal Him." And as there were two Gods, so, according to Marcion, there were two Messiahs - the Messiah of the prophets and the Messiah of the New Testament. The Jewish Messiah was to be a victorious King; the Christian Messiah was to be a suffering Saviour. The one was to rule the nations with a rod of iron, the other was to die as a sacrifice for sin. The one was to be the Deliverer of Israel, the other was to be the Saviour of the world. Jesus eame not to fulfil, but to abolish the law and the prophets and the works of the Creator of the world. ${ }^{1}$ In conformity with these views and his opposition to the Jewish religion, Marcion considered Paul, on account of his conflict with the Judaising Christians, as the only true apostle. Hence he accepted only ten Epistles of Paul, and rejected all the other books of the New Testament, with the exception of the Gospel of Luke, as infected with Judaism. Such a system, at onee compact and consistent, was violently opposed by the early Fathers. Justin Martyr and Irenæus both wrote against it; but the chief opponents of Marcion were Tertullian ${ }^{2}$ and Epiphanius.

But it is the Gospel of Marcion that we have especially to consider, and its relation to the Gospel of Lulie. Besides a work termed à $\nu \tau \iota \theta \dot{\epsilon} \sigma \epsilon \iota$, containing a series of antitheses between the Old Testament, the revelation of the Creator or the God of justice, and the New Testament, the revelation of the supreme God or the God of love, Marcion wrote a gospel. It is no longer extant, but we have numerous cheek, turn to him the other also,' was the commant of the good Gexl."

'So Irensens asserts that Mareion tanght that "Jesus was manifested in the form of a man to those who were in Judiea, abolishing the prophets and the law and all the work of that God who made the world."-Aldv. Ifer. i. 27.2.

2 Tertullian wrote a speecial work against Mareion, in whieh he employs all his vehenence and edrupence. In this loe is followed hy Epiphanius, who, however, wrote independently of Tertullian. 
extracts from it in the writings of Tertullian and Epiphanius. From these extracts it appears that it bears a very close resemblance to our canonical Gospel of Luke. Marcion entitled

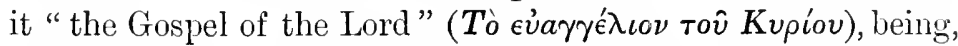
as he supposed, the true Gospel of Christ-the Gospel of the God of love. It commences with the words: "In the fifteenth year of the reign of Tiberius Cæsar, Pontius Pilate being governor of Judrea, Jesus ${ }^{1}$ came down to Capernaum, a city of Galilee, and was teaching on the Sabbath day; and they were astonished at His doctrine, for His word was with authority" (comp. Luke iii. 1, iv. 31, 32). In this Gospel Jesus suddenly appears in the world. ${ }^{2}$ There is no mention of His birth, for this is opposed to the Docetic views of Marcion; nor of His baptism, as the Baptist was regarded as a prophet of the Old Testament. The Gospel of Luke is strictly followed throughout; and, in general, the same order is preserved. There are no statements of incidents or discourses which are not found in Luke's Gospel; there are indeed numerous omissions, but two-thirds of Luke's Gospel are preserved, though in an altered form. The omissions are generally accounted for by Marcion's peculiar views; all those passages being omitted which would seem to recognise the divine origin of the Jewish religion. ${ }^{3}$ Sometimes, however, no reason can be assigned for the omission, as, for example, in the case of the parable of the Prodigal Son, which one would think to be rather in favour of Marcion's conception of the God of the New Testament as the God of love. There are also numerous verbal alterations, most of which can be explained by Marcion's peculiar views. ${ }^{4}$ Several attempts have been made at the reconstruction of Marcion's Gospel

${ }^{1}$ For Jesus, Hahn and Westcott read God, namely, the goorl Gorl, as distinguished from the Creator.

2 Tertullian, Adv. Marcion. iv. 7.

${ }^{3}$ The omissions of Marcion are the following: Luke i., ii., iii., iv. $1-15$, xiii. $1-9$, xiii. $29-35$, xv. 11-32, xviii. $31-34$, xix. 29-48, xx. 9-18, xxii. $35-38$, xxii. $49-51$, xxiv. $48-53$.

4 There is in Marcion's Gospel a curions alteration in the Lord's Prayer. Marcion has, "Father, may Thy Holy Spirit come upon us," instead of, "Our Father which art in heaven, Hallowed he Thy name." Barring-Gould's Lost and Hostile Gospels, 1. 252. Hill's Murcion's Gospel, 
from the numerous quotations given from it by Tertullian and Epiphanins, and from their remarks, as both these Fathers criticise that Gospel passage by passage. ${ }^{1}$ In this manner we can ascertain with tolerable certainty what passages of Lnke's Gospel are omitted and what are retained, as well as in what parts the Gospel of Marcion differs from our third Gospel.

The question arises, What is the relation between the Gospel of Marcion and our canonical Gospel of Luke? Is Marcion's Gospel merely a mutilation of Luke's, made with the purpose of making it correspond with his heretical views? Or, Is the Gospel of Mareion the prior or original Gospel, of which our third Gospel is an expansion and recension? Is it the first edition, so to speak, of Luke's Gospel? On this point the Fathers are unanimous; they with one voice aceuse Marcion of mutilating the Gospel of Luke. Thus Irenæus says: "Marcion mutilates the Gospel which is according to Luke, removing from it all that is written respecting the generation of the Lord, and setting aside a great deal of the teaching of the Lord, in which the Lord is recorded as most clearly confessing that the Maker of the universe is His Father." 2 And Tertullian observes : "It is certain that Marcion has erased everything that was contrary to his own opinion and in favom of the Creator, as if it had been interpolated, whilst anything that agreed with his own opinion he has retained." 3 Some modem critics have, however, impugned these statements, and asserted that they proceeded from prejudice; and that Marcion's Gospel is an original work, and the chief source from which our Gospel of Luke was composed. The first who arlopted this view was Semler, and he has been followed by Eichhorn and his school, as this opinion was favourable to their hypothesis of original docments. Afterwards this opinion was at one time maintained by Baur, p. 25. Hahn, lowever, gives the worls as they are found in our Gospel. See Tertullian, Adv. Hercion. iv. 26 .

1 This was ilone ly Hahn, Erengelium Marcionis ex auctoritute veterum monumentorum; inserted in Thilo's Codex A porrynhes Nori Testamenti, 1'1. 401-486. Hill's Marcion's (rospel is an English translation of the work of Hialn with some variations.
2 dil. Hor. i. 27. 2.
3 Tertullim, Adv. Marcion. iv. 6.
4. Mrercusevungelium, I']. $191 \mathrm{ff}$. 
Ritschl, ${ }^{1}$ Schwegler, ${ }^{2}$ and other crities belonging to the early Tiibingen school. ${ }^{3}$ But, on the other hand, strange to say, the strongest advocate in favour of the patristic opinion, that Marcion's Gospel was a mutilation of Luke's, was Volkmar, one of the most pronounced disciples of the Tiibingen school; and he so convincingly vindicated this view, that most of his opponents were gained over and retracted their opinions. Thus Ritschl says: "The hypothesis propounded by me, that Marcion did not alter the Gospel of Luke, but that his Gospel is a step towards the canonical Luke, I regard as refuted by Volkmar and Hilgenfeld." 5 So also Zeller, belonging to the Tuibingen school, observes: "We may admit as proved and generally accepted, not only that Marcion made use of an older Gospel, but further, that he recomposed, modified, and often abridged it, and that this older Gospel was essentially none other than that of Luke." ${ }_{6}$ Professor Sanday, by a minute critical examination, has proved that the passages omitted by Marcion are written by the same author as those which are retained. ${ }^{7}$ In conseguence of this examination the anthor of Supernatural Religion also acknowledged that he was in error in holding that Marcion's Gospel was the original. $^{8}$ The only theologian, so far as we are aware, who still maintains the paradoxical opinion of the priority of Marcion's Gospel is Baring-Gould. "The Gospel of our Lord," he observes, "if not the original Luke Gospel,-and this is probable, - was the basis of Luke's compilation. But that it was Luke's first edition of his Gospel, drawn up when St. Paul was actively engaged in founding the Asiatic Churches, is the view I am disposed to take of it. . . . All these facts point to

\section{Lucas.}

${ }^{1}$ Das Evangelium Marcions und das Lanonische Erangelizm des

2 Nachapostol. Zeitalter, vol. i. p. 260.

3 See Bleek's Introduction to the N.T. vol. i. pp. 143, 144, notes; and Meyer's Commentary on Luke, vol. i. p. 264, Remark 2, English translation.

${ }^{4}$ Das Evangelium Marcions.

5 Theolog. Jahrbuch, 1851, pp. 528 f., quoted by Meyer.

6 Zeller's Apostelyeschichte, I'P. 11-26: translation, vol. i. Pp. $99 \mathrm{ff}$.

7 Sanday's Gospels of the Second Century, p1. 204-237, and PT. 362-372.

8 Salmon's Introduction to the N.T. p. 245. 
Mareion's Gospel as the original Luke, not, however, quite as it eame to Mareion, Jut editerl by the heretic."

It may now be considered as demonstrated that the Gospel of Mareion is a mutilation of the Gospel of Luke. He first formed his own opinions on the opposition between the Old and New Testaments, - the difference Jetween the God of ereation and the God and Father of the Lord Jesus Christ,the antithesis between Judaism and Christianity, and seleeted the Gospel of Luke as the Gospel which appeared to him best suited for his purpose, and by omissions and alterations adipted it to his opinions. As Bleek observes: "He excludes all passages in which the Gospel history is brought into harmony with the Old Testament revelation, in which the New Testament is represented as the fulfilment of the old Testament propheeies, in which Christ is deseribed as springing from the Jewish nation and of human parentage and partaker of human weaknesses, in which Christ deseribes God, after the manner of the Old Testament, as an avenging Judge." 2 The following alterations will illustrate the method on which Mareion proeeeded. The words, "When ye see Abraham and Isaac and Jacob and all the prophets in the kingdom of God" (xiii. 28), are changed into, "When you shall see all the

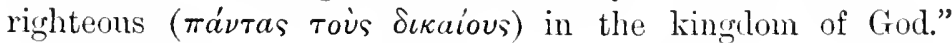
The declaration of our Lord, "It is easier for heaven and earth to pass away, than for one tittle of the law to fail" (xvi. 17), is altered into, "It is easier for heaven and earth to pass away, even as the law and the prophets have passed away, than for one tittle of $\mathrm{My}_{\mathrm{y}}$ words to fail." And the address of our Lord to the diseiples going to Emmaus, "O foolish men, and slow of heart to believe in all that the propliets have spoken" (xxiv. 25), is transformed into, "O foolish men, and slow of heart to believe in all that He spoke to you." 3

Another objection bronght against the Gospel of Luke is its alleged Ehionite tendeney." It is asserted that this

1 Lost and Mostite Crospels, 1]1. 275, 276.

2 Bleck's Introuluction to the N.T. vol. i. p. 149. See also Sanday, Crospels of the second Centur!t, 1. 219.

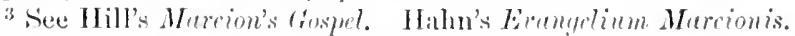

'See Dr. Colin Campledl's C'riticul Sturtis in St. Luke; also Renan's 
Gospel, or at least a considerable portion of it, is the work of an Ebionite. By this is not meant, as the term Ebionite nsually denotes, ${ }^{1}$ the maintenance of a Jewish form of Christianity, the direct opposite of Marcionism, which is certainly not tanght in Luke's Gospel, but the exaltation of poverty and the denmnciation of riches. The reasons for this opinion are, that throughout this Gospel poverty is praised, whilst riches are denonnced. Thus in the beatitudes the words are: "Blessed are ye poor: for yours is the kingdom of God" (vi. 20), without the restriction found in Matthew's Gospel: "Blessed are the poor in spirit." A woe is pronounced upon the rich: "Woe unto you that are rich: for ye have received your consolation" (vi. 24); in the parable of the Rich Man and Lazarus, the rich man is condemned apparently on account of his riches, and Lazarus is saved apparently on account of his poverty and wretchedness; the rich young ruler is told that in order to inherit eternal life he must sell all that he has and give it to the poor; and the widow woman is commended for casting in her mite into the treasury. Now it is true that this Gospel may, in a peculiar sense, he styled "the Gospel of the poor": its consolations are peculiarly addressed to them. But the passages adduced are too few to warrant the conclusion that the Gospel of Luke was composed with a special tendency to exalt poverty and to promote asceticism. Zacchæus, the rich publican, is commended : of him it is said that salvation has come into his house.

\section{The Author of the Gospel.}

In the Greek manuscripts this Gospel is entitled,

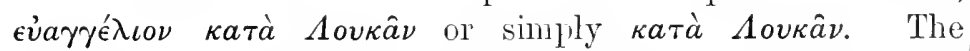
earliest Fathers who quote this Cospel do not assign it to any particular person. The first assertion of the authorship

Introluction to the Tie de Jesus, and Davidson's Introduction to the N.T. 3rd ed. vol. i. pp. $404 \mathrm{ff}$.

1 The Ebionites were a Jewish Christian sect who seceded from the Church about the midkle of the second century. They considered the Jewish law still binding, and held low views of the nature of Christ. 
of Luke which we meet with, is in the Muratorian canon and in the writings of Irencus.

The name Lucas is a contraction of Lneanus, as Silas is of Silvanus. Luke is not to be confounded with Lucius, one of the teachers in the Church of Antioch (Acts xiii. 1), nor with Lucius, mentioned in the Epistle to the Romans (Rom. xvi. 21), as the names are entirely different. $\mathrm{He}$ is thrice mentioned by I'aul in his Epistles (Col. iv. 14; I'hilem. 24; 2 Tim. iv. 11). Some suppose that he is also alluted to in 2 Cor. viii. 18 , where Paul says: "We have sent together with him (Titus) the brother whose praise in the Gospel is spread through all the Churches; and not only so, but who was also appointed by the Churehes to travel with us in the matter of this grace": not because there is any allusion in the words, "whose praise is in the Gospel," to the Gospel of Luke, lut becanse Luke was one of the deputies of the Churches who went with Paul to Jerusalem; and he might have been sent along with Titus to take charge of the contribution of the Church of Corinth. We are ignorant of the birthplace of Luke. Eusebius, Jerome, and Nicephorus inform us that this was Antioch $;^{1}$ but this may have arisen from confounding him with Lueius of Cyrene (Acts xiii. 1); other's fix on Troas, becanse there he first joined the apostle; and others, as Greswell, conjecture that he was an inhabitant of Philippi, because, according to the narrative of the Acts, he appears to have resided there for several years. From a statement made by Paul (comp. Col. iv. 11 with ver. 14 ), he appears to have been a Gentile by birth. The purity of his Greek, and the comprarative absence of Hebraisms, are in favour of his Gentile origin, thongh these nily be accounted for on the supposition that he was a Hellenistic Jew. It is clouldful whether he was a proselyte to Judaism before his eonversion to Christianity, as Jerome asserts, and als his atequintance with Jewish rites and ordinances wouk seem to inply. l'anl calls him "Luke, the belover physician" ((')l. iv. 14); and some think that there are proofs of his medieal knowlerge to be found in his writings from the precise and exict mamner in which he 1 Einselnils, Mist. Eerl. iii. 4. 
speaks of diseases and miracles of healing: 1 as that Peter's mother-in-law was afflicted with a great fever ( $\pi v \rho \in \tau \hat{\omega}$

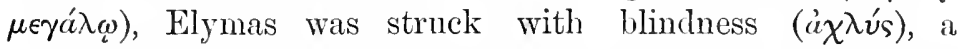
technical term (Acts xiii. 11), and the father of Publius lay

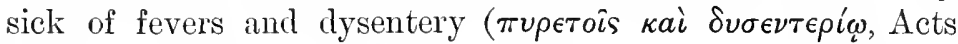
xxviii. 8); but the argument from these and similar expressions is overdrawn. Grotius supposes that Luke was originally a slave, because the most eminent physicians mentioned in Roman history were of this class: ${ }^{2}$ but there is no ground for this supposition, as among the Greeks the medical profession was highly esteemed and practised by men of liberal education.

We learn from the Acts that Luke was the companion of Paul. The author of the Acts joined Paul on his missionary journeys at Troas, when the style of narrative changes from the indirect to the direct form: instead of the third, the first person pronom is employed (Acts xvi. 10). He passed with the apostle into Macedonia, and was with him at Philippi (Acts xvi. 11, 13). Here he appears to have remained behind, for the narrative again changes from the first to the third person; and it is not until Paul's return, seven years after, to Philippi that the direct form is resumed (Acts xx. 6). Hence it is with some probability assumed that Luke remained at Philippi. He was doubtless one of the messengers of the Churches who accompanied the apostle on his last momentous journey to Jerusalem (Acts xxi. 1, 15, 17). Probably he remained with Paul during his imprisonment of two years at Cesarea, for he sailed with him from that city to Rome (Acts xxvii. 1-3, xxviii. 16). $\mathrm{He}$ was with the apostle during his first Roman imprisonment, when Paul wrote the Epistles to the Colossians and to Philemon (Col. iv. 11; Philem. 24), and was also with him during his second Roman imprisonment, remaining with him to the close of his life (2 Tim. iv. 11). "He was," says Irenæus, "always attached to and inseparable from Paul."3

1 Hobart, The Medical Language of St. Luke.

2 As Antestius the physician of Julius Cresar, and Antoninus Musa the physician of Augustus.

${ }^{3}$ Adv. Her. iii. 14. 1. 
We have few notices of Luke in the patristic writings and in the early eeclesiastical histories, and all of then are of a legendary character. Epiphanius informs us that he was one of the seventy diseiples, probably because it is only in the Gospel of Luke that the mission of the seventy is recorded; but this statement is refuted by Luke himself, who in the preface to his Gospel evidently implies that he was not one of our Lord's immeliate followers (Luke i. 1-3). For the same reason the plausible assertion of Theophylact, that he was one of the disciples going to Emmaus to whom Jesus after His resurreetion revealed Hinself, is to be rejected. The tradition that he was a painter rests on the authority of Nicephorus of the fourteenth century, and is entitled to no eredit. ${ }^{1}$ It seems to have arisen from a rude picture of the Virgin being found in the Catacombs with the inscription that it was one of the seven painted by Lnea. Aceording to Epiphanius, he preached the gospel in Dalmatia, Gallia, Italy, and Macedonia. According to Jerome, he died a natural death in the eighty-fourth year of his age. Gregory Nazianzen reckons him among the martyrs; and aecording to Nicephorus he returned to Greece, where he suffered martyrdom by being hanged on an olive tree in the eightieth year of his age. His remains were removed to Constantinople by the order of Constantine. ${ }^{2}$

As, aceording to the Fathers, there was a close connection between the Apostle Peter and the evangelist Mark, so they held that there was a similar connection between Paul and Luke. The Cospel of Luke was reginded by them in a curtain sense as the Gospel of Paul. Thus Irenaus observes: "Luke, the companion of Paul, recorded in a book the gospel preached by him." 3 Tertullian says: "Men usually aseribe Luke's form of the Ciospel to Paul." A And Origen writes: "Among the four Cospels which are the only indisputable ones in the Church of Cod, I have learned by

1 Nicephorus, Mist. Eecl. iii. 4.

2 See Baring-(inull's Lives of the Suints, () toluer 18; Winer's Biblisches Realwirterluch; Cinve's Lives of the Apostles.

${ }^{3}$ [renase, $A d x . M \omega r$. iii. 1. 1.

'Tertullim, dde. Murion. iv. 5. 
tradition ... that the third was written by Luke, the Gospel commended by Paul, and composed for Gentile converts." ${ }^{1}$ The Gospel of Luke was not, however, so closely dependent on Paul as that of Mark was on Peter. Panl was not himself a follower of Christ when He was in this world, and although he may have materially assisted Luke in the composition of his Gospel by suggestions and by information imparted, yet the evangelist must have derived his facts from other sources, and must have been in direct conmunication with those who were the immediate followers of the Lord. There is undoubtedly a closer comnection with the Panline phase of doctrine in this Gospel than in the other Gospels. The account of the institution of the Lord's Supper, as given by Luke, bears a close resemblance to that given by Paul in the First Epistle to the Corinthians (compare Luke xxii. 19, 20 with 1 Cor. xi. 23-25). The Fathers in general supposed that when Paul speaks of "his Gospel" (Rom. ii. 16, xvi. 25; 2 Tim. ii. 8), he means the Gospel of Luke, composed as they imagined under his superintendence. Thus Eusebius says: "They say $(\phi a \sigma i)$ that Paul meant to refer to Luke's Gospel whenever, as if speaking of some Gospel of his own, he used the words 'according to my Gospel.".2 And the same remark is made by Jerome: "Some suppose that whenever Paul in his Epistles makes use of the expression 'according to my Gospel,' he means Luke's writing." 3 All this is mere supposition, as these Fathers themselves seem to imply, and is unsupported by any evidence.

\section{SOURces of Luke's Gospel.}

On this point we have some solid ground to go. In his preface, Luke gives us information of the sources from which he derived his Gospel: "Forasmuch as many have taken in hand to draw up a narrative concerning those matters which have been fulfilled among us, even as they delivered them unto us, which from the beginning were eye-

${ }^{1}$ Eusebius, Hist. Eccl. vi. 25.

2 lbid. iii. 4.

${ }^{3}$ Jerome, De vir. illustr. ch. vii. 
witnesses and ministers of the word, it seemed good to me also, having traced the course of all things aceurately from the first, to write unto thee in order, most excellent Theophilus; that thou mightest know the certainty concerning the things wherein thou wast instructed" (Luke i. 1-4). From these words it is evident that the evangelist affirms that he himself was not an eye-and ear-witness of the works and discourses of the Lord, for he evidently distinguishes himself from those who were eye-witnesses and ministers of the word. At the same time, he asserts that he was fully qualified to write an account of the actions of Christ; that he possessed sufficient knowledge; that he had traced

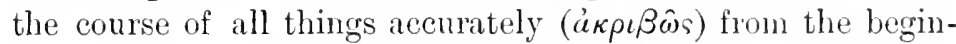
ning. He mentions two sources of information which he possessed. The first was the oral information which he received from his intercourse with those who had been with Christ - the apostles and diseiples of the Lord. This he would carefully ascertain, and under the guidance of the Spirit of God commit to writing. And the second source of information was the narratives of those who were the followers of Christ, many of which had been committed to writing; there were not only oral traditions, but written documents, to which he could refer.

The first sonrce of Luke's information was oral tradition. Here Luke had peculiar advantages. He appears to have been for a consilerable period resident in .Judien, in all probability during I'aul's two years' imprisonment at Carsarea. He would thus come into direct contact with many who had been the atual followers of Christ; most probalily with some of the apostles, and certainly with Jannes the Lord's brother, the so-called bishop of Jermsalem (Acts xxi. 1s), and with Philip the evangelist, whom he met at Ciesarea (Acts xxi. 8). He had also the advantage of the information which Panl could impart to him, for that apostle must have had frequent communication with the original apostles. The account whieh Luke wives of the birth of .Joln the Baptist, of the visit of the angel to the Virgin, and of the eircumstantes attending the birth of the Lord and His presentation in the temple, might have been obtained hy him, either from Mary herself, or from tames and the other 
brethren of our Lord. As he himself tells us, he used the greatest diligence in the collection of the facts and sayings of our Lord.

The other source of information consisted of written documents, These, he asserts, were numerous. "Many ( $\pi \circ \lambda \lambda \circ i)$ have taken in hand to draw up a narrative." We have already had occasion to remark that such evangelical fragments would be abundant in the early Church. Of these Luke would make a careful selection, guided in doing so by a higher wisdom than his own. As we have already stated, he might have had access to a narrative, either oral or written, which does not appear to have been used by the other two evangelists, the so-called Perrean section (Luke ix. 51-xviii. 41). ${ }^{1}$ These documents Luke would not employ slavishly, but freely, working them into his narrative. According to Schleiermacher: "Luke is from the beginning to end no more than a compiler and arranger of documents which he found in existence, and which he allows to pass unaltered through his hands." "His great merit consists in this, that he has admitted scarcely any pieces but what are peculiarly genuine and good." 2 But this is a most erroneous view of the formation of the Gospel of Luke, and is refuted by the miformity of style and diction which pervades the whole book, as well as the Acts of the Apostles, proving the unity of authorship, and the freedom with which the author used his materials.

It is, however, a very difficult question to determine how far the Gospels of Matthew and Mark are to be classed among the documentary sources of Luke's Gospel. We have already discussed the subject when considering the sources of the Synoptic Crospels, ${ }^{3}$ and found it one of extreme difficulty, hardly admitting of a satisfactory solution. There is nothing incredible in the supposition that Luke made use of these Gospels, as we consider that they were previously written. But we found that there were reasons for calling

1 See supre, pp. 34, 35 .

a Schleiermacher's Critical Esscty on the Gospel of St. Lulie, translated by Thirlwall, p1. 313, 314. See also Renan's Life of Jesus, 1'. xlviii, English translation.

${ }^{3}$ See supra, pp. 48, 49. 
in question his use of Matthew's Gospel, especially on aecount of the differences in the genealogies and in the narrations of the birth of Christ and of His resurrection in the two Gospels; and we are disposed to infer that Luke had not aecess to Matthew's Gosprel. lint it is otherwise with the Gospel of Mark. Considering the similarity of the ineidents recorded and of the chronological order of the narrative, and the frequent identity of expression, the probability, anounting however by no means to certainty, is that the narrative of Luke is to a certain extent dependent on the Gospel of Mark. ${ }^{1}$ There is nothing in the prefaee of Luke to forbid this; there is no condemmation in it, as some think, of the previous narratives that were undertaken. At the same time, it must be admitted that there are portions of Mark's Gospel wanting in Luke which we woukl not expect to have been omitted had Luke that Gospel before him; not only those few parts that are peeuliar to Mark, but other portions which are inserted in Matthew's Gospel, but wanting in Luke. All these reasons for and against must leave the question under considerable meertainty.

\section{Design of the Gospel.}

Both the Gospel of Luke and the Aets are aduressed to a certain Theophilus (Luke i. 3 ; Aets i. 1). The epithet критьбтоs, most noble, prefixed in the Gospel to lis name, seems to intimate that he was a person of rank, as this is an epithet which generally refer's, not to character, but to station. It is the same epithet which is given by ('lindius Lysials and Tertullus to Felix (Acts xxiii. 26, xxiv. :3), and by Panl tu Festus (Acts xxvi, 25). Theophilus was evillently a Christian, ats it is stated that he harl been a catechumen,

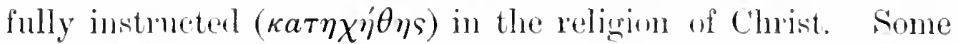
of the Fathers (()rigen, Ambrose, Ejpiphanins) suppose that

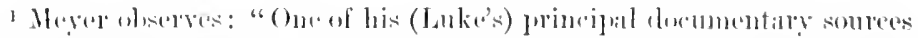

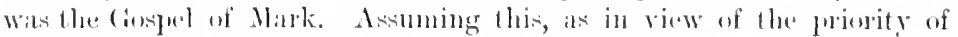

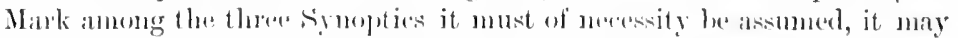
le matter of dombt whether Mattlew also in his jeresent form was made use of by him or unt." On Lulie, rol. i. 1. 261. 
the word is not a proper name, but an appellative, denoting a lover of God, and applicable to every Christian reader; but its occurrence in two historical works refutes this opinion. Others (Michaelis, ${ }^{1}$ Theodore Hase), wishing to identify him with some historical character, suppose that he may have been the same as Theophilus, the son of Ammas, the high priest, who was deposed by King Agrippa, ${ }^{2}$ and that the third Gospel and the Acts were apologies for Christianity,an extravagant opinion, at variance with the dedication of the Gospel, which implies that Theophilus was a Christian. Some think that he was a native of Alexandria, and other's a native of Italy; in all probability he was a Greek Christian of some position and influence.

The immerliate design of the Gospel was, according to the preface, that Theophilus might know the certainty of those things wherein he was instructed. But this address to Theophilus must be considered rather as a dedication of the work than a statement of its nature and contents. The Gospel was written for the purpose of giving an authoritative account of the ministry of Jesus for the instruction of Christians, and especially of Gentile Christians. "Luke," says Origen, "composed his Gospel for Gentile converts." This statement is seen to be correct from an examination of its contents. There are explanations of Jewish customs and localities which would have been unnecessary for Jews, but necessary for those who were ignorant of the religious customs of the Jews and of the geography of the Holy Land. Thus we are informed that the Feast of Unleavened Bread is called the Passover; that Nazareth and Capernamu are cities of Galilee; that the country of the Gadarenes lies over against Galilee; that Arimathea is a city of the Jews; and that the village of Emmaus is about threescore furlongs from Jerusalem. ${ }^{3}$ In his genealogy Luke traces the descent of Jesus not only to Abraham, at which point Matthew stops, but to Adam, the father of the human race. There are numerous references to the Gentiles and the non-Jewish

1 Marsh's Michaelis, rol. ir. p. 239, 2nd ed.

2 Josephus, Ant. xviii. 5. 3, xix. 6. 2.

${ }^{3}$ Davidson's Introduction to the N.T. vol. i. p. 186. 
races; Christ was to be a light for revelation to the Gentiles (Luke ii. 32); it was a Silnaritan who is represented as having hat comprassion on the man who fell among thieves; and the leper, who only among those who were cleansed returned to express his gratitule, was a simaritan. As the Gospel of Matthew was arderessed chietly to Jewish realers, so the Ciospel of Luke was addressed chiefly to Gentile reaters. The one may be ealled the crospel of the circumcision, and the other the Gospel of the meiremeision.

\section{Tile Language of the Gospel.}

The Greek of Luke, both in his Gospel and in the Acts of the Apostles, is comparatively pure. The evangelist las great mastery of the language, and is very eopious in his use of words. It has often been remarked that the purity of the preface approaches classical Cireek; and in the narrative itself, when he writes with freedom and independenee, the style and diction are generally pme and correct. The Hebraisms are chiefly restrieted to those passages where it would appear that the author uses oral tradition, or has recourse to written docmments. Thus the first two chapters of the Gospel are full of Hebraic expressions. So also the secoml part of the Acts of the Apostles is purer than the first, beause Inke there wrote from his own observation, and was less dependent on the writings of others.

There is a remarkable indiviruality in the style and diction of Iuke. This has been earefully examined by several writers, espeeially by Credner and Dr. Samuel Davidson. Credner nentions sixty-five lingnistic peculiarities in the writings of Lulie, ineluding both the Acts and the cospel, whilst 1)r. Jitridson increases the number to $123 .{ }^{1}$ "The following are the most remarkalle of these peenliarities mentioned by these crities. The frepuent use of кapoía, answering to the Holnew use of zh: oikos in the sense of

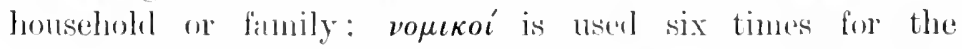

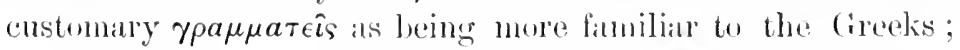

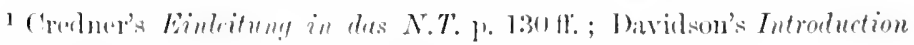
to the study of the N.T. vol. I. I11. 138-1.17, 3rel il. 
for the same reason $\dot{\epsilon} \pi \iota \sigma a \operatorname{t} \eta s$ is used six times instead of the Hebrew $\dot{\rho} a \beta \beta i$; the Sea of Galilee is called $\lambda i \mu \nu \eta$ instend of $\theta \dot{\alpha} \lambda a \sigma \sigma a$, as in the other Gospels; the preposition $\sigma \dot{v} \nu$ is used in preference to $\mu \in \tau a$, employed by Matthew and

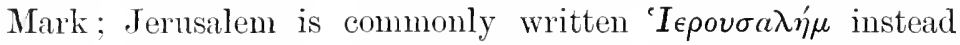

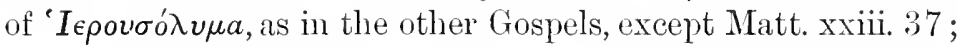

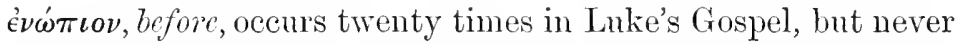

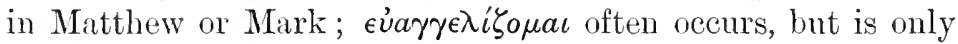
once used by Matthew, and never by Mark or John ; zápıs is frequently used by Luke, but never by Matthew or Mark; when speaking of Christ, Luke often calls Him ó кúpıs (vii. 13,31 , x. 1 , xi. 39 , xxii. 61 ), - a title which is not used by Matthew, and only twice by Mark in the disputed verses at the close of his Gospel (Mark xvi. 19, 20). A long list of words, extending over three and a half pages, is given by Dr. Davidson, used only by Luke among the Synoptists. ${ }^{1}$ Dr. Schaff observes: "The vocabulary of Luke considerably exceeds that of the other evangelists; he has about 180 terms which occur in his Gospel alone, and nowhere else in the New Testament; while Matthew has only about 70 , Mark 44, and John 50 peculiar words. Luke's Gospel has 55 , and the Acts 135 ä $\pi a \xi \lambda \epsilon \gamma o ́ \mu \epsilon \nu a$, and among them many verbal compounds and rare technical terms." 2 All this shows the command which Luke had of the Greek language; thus confirming the opinion, that of all the writers of the New Testament he alone was not a Hebrew or Hellenistic Jew, but a Greek by birth.

\section{Vi. The Characteristics of the Gospel.}

Luke's Gospel has many peculiar characteristics. Among these may be mentioned its completeness. It legins with the birth of Christ, or rather with the Annmeiation, follows Him through all the stages of life, and terminates with His Ascension. Luke alone gives us the account of the Annunciation, and narrates the birth of our Lord at Bethlehem

${ }^{1}$ Dr. Davidson's Introduction to the Stuly of the N.T. 3rd ed. vol. i. pp. 447-453.

2 Schaff's History of the Church, vol. ii. 1'.665. 
differently in several respeets from the narrative of Matthew. He alone tells us of the annomeement of the lirth of Christ to the shepherds; and he alone informs us of the presentation of the child Jesus in the temple. Whilst the other evangelists pass over in silence the thirty years of our Lord's life before the eommeneement of His public ministry, Luke relates an ineilent of His boyhood, when, at the age of twelve, He aceompanied Joseph and Mary to Jerusalem, and was found anong the doctors, hearing them and asking them questions (ii. 42). He alone adverts to the development of our Lord's youthful years, saying that He inereased in wisdom and in stature (ii. 52). Whilst, like the other evangelists, he gives an account of our Lord's ministry in Galilee, and of His sufferings, death, and resurrection, Luke closes his Cospel with the account of the ascension (xxiv. 50). ${ }^{1}$ And in the mention of the promise of the Father, for which the apostles were commanded to wait at Jerusalem (xxiv. 49), Luke mites his Gospel with the fulfilment of that promise as recorded in the Acts of the Apostles.

Another striking and more marker featme in Luke's Gospel is its universality: it is emphatically the Gospel of universal salvation, the Gospel of the Gentiles. It is not restrieted to the Jews; there is a largeness, a fulness, and a breadth about this Gospel which are not so discernible in the other Gospels. The ineorporation of the Gentiles into the Chureh of Christ is in a manner antieipated. There are many intimations that the wall of separation between Jews and Gentiles was to be broken down, and that the peenliar privileges of the Jews, as the people of ciod, were to be done away with; that the Ciospel of Christ was to be a universal religion, and was to enbrace the whole workd; that in the language of St. l'aul, God was the Gorl of the Gentiles, and not of the Jews only (Rom. jii. 29, ix. 24). The angels who proclaimer the liirth of the Lord to the shepherds on the platins of Bethlehem announced goolwill to men (ii. 14); the aged simeon, in his song of thanksigiving, greeted the infant Sariour as a light for revelation to the Gentiles, as

1 Matthew has no reference to the asension; Mark alludes to it in the disputed passage at the elose of his ciospel. 
well as for the glory of the people of Israel (ii. 32). To the prediction of Isaiah anmouncing the preaching of the Baptist, the words are added: "And all flesh shall see the salvation of God" (iii. 6). ${ }^{1}$ Whilst the other evangelists record the mission of the Twelve, as representing the nation of Israel, Luke alone relates the mission of the seventy disciples as representing the nations of the world (x. 1). ${ }^{2}$ The distinction between the Jews and the Samaritans is abolished: no preference is given to the former; the disciples are rebuked for wishing to call down fire from heaven to destroy the inhospitable Samaritans (ix. 54); in the parable of the wounded Traveller, whilst the priest and the Levite pass by on the other side, it is a Samaritan who is represented as having compassion on him ( $x .33)$; of the ten lepers who were cleansed, the only one who returned to give thanks was a Samaritan (xvii. 16). Our Lord Himself affirms, that "the Son of Man came to seek and to save that which was lost" (xix. 10). And His commission to His disciples was, that repentance and remission of sins should be preached unto all nations, beginning at Jerusalem (xxiv. 47). The same universality is indeed exhibited in all the Gospels, but in the Gospel of Luke it is more fully and more frequently mentioned. ${ }^{3}$ Luke's Gospel is the gospel of free salvation : the freedom of the grace of God is here proclaimed; there are no restrictions; salvation is a matter, not of works bestowed as a reward, but of grace bestowed on the penitent: the Panline doctrine of free justification is foreshadowed; Zaccheus, the publican, was accepted by the Lord; the woman that was a sinner was graciously parloned on her repentance; and the penitent thief received the promise of admission into paradise.

The Gospel of Luke is pre-eminently the Gospel of the

1 This addition to the prophecy in Isa. xl. 3, 4, is taken from Isa. lii. 10.

2 Seventy was, ly the Jews, supposed to be the number of the nations of the world.

${ }^{3}$ Those statements in St. Matthew's Gospel, where the Twelve are forbidden to go to the Gentiles, but to restrict themselves to the lost sheep of the loonse of Israel (Matt. x. 5, xv. 24), are omitted in Luke's Gospel. 
humanity of Christ, exhibiting His human tenderness and love. Whilst Matthew proclaims. Jesus as the Messiah of the Jews, and Mark as the Son of God, the worker of miracles, Luke dwells specially on His manhood, as the Son of Man and the Saviour of the worle. ${ }^{1}$ The manhood of Christ is deseribed in its growth and in its limitations; the doctrine of the kenosis,

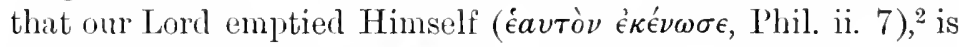
here distinetly taught. We are told that Jesus grew up as one of the children of men; He passed from infancy to youth, and from youth to manhood; there was a development of His human nature; He not only grew and waxed strong pliysically, but also mentally; He grew in wisdom, and in favour both with God and man (ii. 40, 52). Luke dwells upon the tender human sensibilities of His nature. He alone nentions the tears which in the hour of His trimmph He shed over Jerusalem. He alone gives the account of His bloody sweat in Gethsemane, when an angel had to be sent from heaven to strengthen His human nature to endure the agony. In neither of the other two Synoptists have we such an insight into the tenderness and love of Christ; we see into His heart, a human heart which beats with love: in this respect the Gospel of Luke resembles that of John. The love, and tenderness, and merey of our Saviour are diselosed to us. "He came to heal the broken-hearted." Most of the parables peculiar to Luke, as the Lost Piece of Money, the Prodigal Son, the Good Samaritan, exhibit the merey and love of our God. God is represented as our Father, who rejoices in the recovery of His lost clildren, in the restoration of the erring, and in the delivermee of the wretched from their miseries. It is Luke alone who tells us of the penitent woman who lay at our Saviour's feet and bathed them with her tears, and who was so tenterly receiven by Hin. It is Luke alone who relates the gracious reception of Zacehaeus, who wis looked down upon by his eountrymen as an outeast and a simner. And it is Luke

1 "Das Evangelinm des Mensedensolmes, der IHumanitat Christi, der Verklurung allere Humanitit," Lange.

2 The dowtrine of the henesis is a great mystery, which has not as get received suffieient ansideration. On it we alle not alled npon to enter; it belongs to the spluce of dogmat ies. 
alone who mentions our Lord's prayer on the cross for the forgiveness of His enemies, and His gracious reply to the request of the dying thief: "To-day shalt thou be with me in paradise." In this Gospel espeeially we are taught in the language of the author of the Epistle to the Hebrews that "we have not a high priest that camot be touched with the feeling of our infirmities; but one that hath been in all points tempted like as we are, yet without sin" (Heb. iv. 15). Jesus Himself is the Good Samaritan, the Shepherd who leaves the ninety and nine, and goes into the wilderness to seek the sheep that was lost.

In this Gospel prominence is given to vomen. It has not inappropriately been termed the "Gospel of womanhood." It opens with the mention of Elizabeth the mother of the Baptist, who with her husband Zaeharias walked in all the eommandments and ordinances of the Lord blameless (i. 6). Luke alone adverts to the pious character of the blessed Virgin, and records her song of thanksgiving. He alone mentions Anna, the aged widow of fourscore and four years, who departed not from the temple, but served God with fastings and prayers night and day (ii. 36). He, with John, mentions the sisters of Bethany; Martha, careful and tronbled about many things, and Mary, sitting at the Saviour's feet and listening to His words (x. 38-41). He alone tells us of the widow of Nain, and of the compassion of the Lord (vii. 11). It is in this Gospel that we read of the penitent woman, who anointed our Lord's feet, and bathed them with her tears (vii. $36-39$ ). It is from Luke that we learn that many pious women followed our Lord in His missionary journeys through Galilee, ministering to Him of their substance (vii. 1-3), and accompanied Him on His last journey to Jerusalem, and who, when all His male disciples forsook Him and fled, remained faithful to the last (xxiii. 49). It is Luke who records our Lord's address to the women who followed Him to the cross bewailing and lanenting Him: "Danghters of Jerusalem, weep not for Me, but weep for yoursclves, and for your children" (xxiii. 28).

There are in the Gospel of Luke numerous striking and instructive contrasts; lights and shadows are mingled 
thronghout the narrative. Thus, for example, the doubting Zacharias the father of the Baptist, and the humble and conficling Mary the mother of our Lord; the anxious and busy Martha, and the humble and devont Mary; the prond and self-righteons Pharisee, and the abased and penitent publican; the rieh man elothed in purple and fine linen, and faring sumptuously every day, and the beggar Lazarus, full of sores, and fed with the crumbs which fell from the rich man's table; the priest and the Levite who passed by, and the Samaritan who had compassion on the wounded traveller; the mingrateful nine lepers, and the tenth, a Simaritan, who alone returned to render thanks; the elder son, who never left his father's honse, and the younger son, who turned prodigal, and was restored to his father's love and confidence; Simon the self-righteous Pharisee who loved little, and gave the Lord no water to wash His feet, and the woman who was a sinner, who loved much and washed His feet with her tears; the penitent thief on the right hand, and the impenitent thief on the left.

It is from Luke's Gospel that those spiritual songs are taken which have been used in all ages in the worship of the Christian Church; as the Ave Maria, the song of the Anmunciation (i. 28-31); the Magnificat, the song of Mary (i. $47-50)$; the Benedietus, the song of Zacharias (i. 68-79); the Gloria in Excelsis, the song of the Angels (ii. 14); and Nune Jimittis, the song of Simeon (ii. 29-32). All these spiritual songs are contained in the first two chapters of Luke's Cospel; indeed, it is only in this Gospel and in the Apocalypse that spiritual songs are to be found. They are all Hebraic in their sentiment and dietion, and have been rendered into JIebrew withont any loss of their beanty. We have in the Guspel of Luke the last of the Hebrew Psatms and the first of the Christian hymms.

Such are the characteristies of the Ciospel of Luke. It is, as Dean Far'ar remarks, "the Gospel of the Greek and of the future; of eatholicity of mind; the (xospel of hymus and of prayers; the Gospel of the Savionr; the ciospel of the universality and gratuitomsness of silvation; the fospel of holy toleration; the Gospel of those whom the religions world regards as hereties; the Gospel of the publican, and the 
ontcast, and the humble poor, and the weeping Magdalene, and the crucified malefactor ; the Gospel of the lost piece of money and the lost sheep; the Gospel of the good Samaritan and of the prodigal son; the Gospel of the saintly life, of pity, of forgiveness obtained by faith, of pardon for all the world; the Gospel of grace and of the glad tidings of free salvation; the Gospel of Him who was, as we all are, the son of Aclam, and who died that we all might be the sons of God." 1

\section{The Integrity of the Gospel.}

As the first two chapters of the Gospel of Matthew, especially the account of the birth and infancy of Christ, have been disputed; so, in like manner, the narrative of the miraculous conception and of the infancy of Christ in the Gospel of Luke (i. 5-ii. 52) has been called in question. The first who cast doubts on this passage was Evanson, toward the close of last century (1792), in his Dissonanee of the four generally receired Evangelists. ${ }^{2}$ In this he was followed by Eichhorn ${ }^{3}$ and Baur. ${ }^{4}$ On the other hand, the genuineness of the passage has been defended by such rationalistic critics as Ammon, Paulus, Credner, Kuinoel, Volkmar, and Köstlin. The chief objections were its omission in the Gospel of Marcion, and its supposed irreconcilability with the narrative of the birth and infancy of Christ as given by Matthew. These objections are of no force. The genuineness of the passage is demonstrated beyond dispute by its presence in all the Greek manuscripts and in all versions of the New Testament, and by the repeated references to it in the writings of the early Fathers. It is true that the section was wanting in Marcion's Gospel; but, as we have seen, Marcion mutilated and abbreviated the Gospel of Luke to suit his own preconceived dogmatic opinions. We have already discussed the differences between the accounts of the infancy given by

${ }^{1}$ Farrar's Messuges of the Books, 1. 86.

2 This work was answered by Priestley, Letters to a Young Mon, 1793, and by the Rev. Thomas Faleoner in the Bumpton Lectures for 1811.

${ }^{3}$ Einleitung in das N.T. vol. i. p. 630.

4 Baur's Marlusevangelium, p. 218. 
Matthew and Luke, and shown that these differences are capable of reconciliation, and do not amount to a discrepancy in the accounts themselves. ${ }^{1}$ As already remarked, Luke might have obtained his information, either from Mary herself, whom it is not improbable he may have met in Jerusalem, or from James the Lord's brother, whom he certainly did meet (Acts xxi. 18), or from the other brethren of the Lord.

An important difference in reading is found in the Gloria

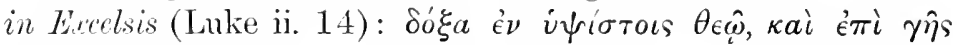

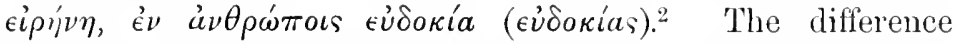

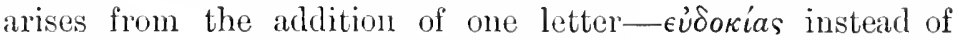

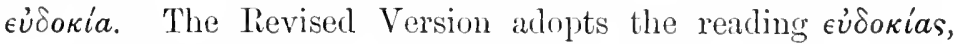
and translates: "Glory to God in the highest, and on earth peace among men in whom $\mathrm{He}$ is well pleased"; with the footnote: "Many ancient authorities read "Peace, good pleasure among men'; and instead of 'Men in whom He is well pleased,' a footnote gives the alternative rendering, 'Men of good pleasure.' "

The reading evionias of the Revised Version is supported by the principal ancient manuscripts $\wedge$ A B D : C (the Codex Ephrem) is defective. The combined testimony of such valuable and independent mannscripts as the Vatican and the Alexandrian is very strong. Among the versions the old Latin and the Vulgate also have this reading; the Vulgate renders the clanse in hominibus bonce voluntatis. The Latin Fathers adopt the reading of their own version; whilst among the Greek Fathers, Origen alone is favourable, although he also uses єủoкía.

On the other hand, the rest of the uncials and all the

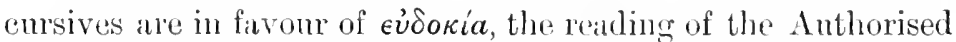
Version; such also is the reading of the Syriac, Armenian, and Ethiopic versions; the Greek Fathers may be considered as unanimons in their testimony; even Origen, in his work against Celsus, ardopts this realing: "At the birth of Jesus a multitude of the heavenly host praised God, saying:

I See supre, l'P. $115 \mathrm{fl}$.

2'This hardly belongs to the disenssion on the integrity of the Gospel, but is here given on aceount of the interest attached to this reading. 
Glory to God in the highest, and on earth peace, goodwill towards men." 1

But whilst the external evidence, owing to the combined testimony of the most important of the uncial manuscripts, is in favour of the reading eviosias, the internal evidence is

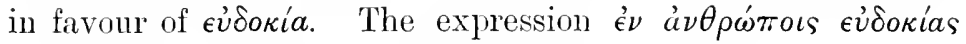
is certainly the more difficult reading, and this is so far in its favour; yet it is very obscure, and so difficult of translation, that a reasonable sense can hardly be made ont of it; literally rendered it is "among men of good pleasure." The Revisers render it "among men in whom He is well pleased"; others, "to the men of goodwill,"; others " to men who are the object of goodwill"; and others, "peace on earth to those who will have it." Origen, in those places where he adopts

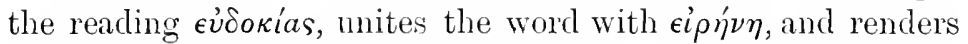
the whole passage: "Glory to God in the highest, and on earth the peace of good pleasure to men,"-a meaning which, Dr. Hort says, "would deserve serious attention, if no better interpretation were available." 2 In short, as Scrivener observes of these and such like interpretations, they "can be arrived at only through some process which would make any phrase bear almost any meaning which the translator might like to put upon it." 3 Such a reading also narrows the expression "goodwill" to a certain class of men, instead of making it embrace the whole human race, as is naturally suggested by the preceding words, "on earth peace."

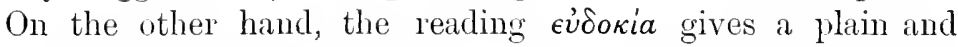
intelligible sense-goodwill to men: the goodwill being the goodwill of God-His merey and good pleasure. This also better preserves the parallelism of the passage, divided into three sentences: "Glory to God in the highest; on earth peace; goodwill toward men." According to the other rendering, the parallelism consists of only two members: "Glory to God in the highest; on earth peace to men of goodwill." Others render it: "Glory to God in the highest and on earth; peace to men of goodwill."

1 Contru Celsum, i. 60.

2 Westcott and Hort's Greeli New Testument, Select Readings, vol. ii.p. 56.

"Sevivener's Biblical Criticism, rol. ii. 4th ed. p. 347 . 


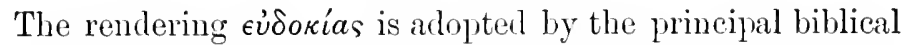
critics - Lachmann, Tischendorf, Tregelles, Alford, Meyer, Westcott and Hort; whilst Scrivener, Burgon, and Cook

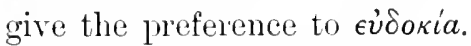

Another important passage where there is a remarkable difference in the reading, is luke's rersion of the Lord's Prayer (xi. 2-4). In many anthorities the prayer is given in an abbreviated form, and this is the reading adopted in the Revised Version: "Father, Hallowerl be Thy name. Thy kingdom come. Give us day by day our daily bread. And forgive us our sins; for we ourselves also forgive everyone that is indebted to us. And bring us not into temptation." The rearling of the Authorised Version is relegated to the footnotes.

The reading here adopted by the Revisers is that of the Vatican and the Sinaitic: ${ }^{1}$ whilst the Alexandrian has the reading of the Authorised Version. The other manuscripts vary; some agree with the Vatican and others with the Alexandrian; and some, onitting one or two clauses, give the prayer in a partially abbreviated form. The same is the case with the different versions; for example, the Vulgate omits the words: "And deliver us from evil." It is argued that the internal evidence is in favour of the abbreviated form, because transeribers would be induced to supply the omitted petitions from the Gospel of Matthew. At the same time, in this form the prayer certainly aplears to want completeness. The occasions when the prayer was delivered were, according to the Gospels of Matthew and Luke, very different. In Natthew it ocenpies part of the Sermon on the Momut, and stands in elose comection with what precedes, being attached to omr Lord's injunction against hypocrisy in our prayers; whilst in Luke it is given in answer to the reunest of the diseiples: "Lord, teach us to

1 The following is the rearling of the Vatienn: Ilareo, aryagdira ri

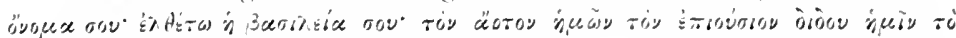

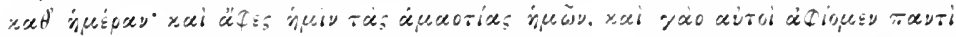

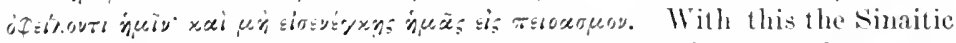

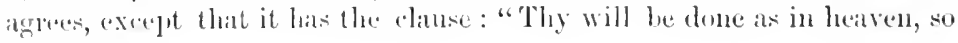
(1) callt." 
pray, even as John also taught his disciples." There is no improbability in supposing that our Lord delivered this prayer to His disciples on two different occasions.

Perhaps a still more important passage is the incident of the bloody sweat in Gethsemane, omitted by the other evangelists and given only by Luke: "And there appeared unto Him an angel from heaven, strengthening Him. And, being in an agony, He prayed more earnestly: and His sweat became as it were great drops of blood falling down upon the ground" (xxii. 43, 44). We shall consider the evidence against and for its genuineness.

// 1. Evidence against the genuineness of the passage.-These verses are omitted in the two important manuscripts, the Alexandrian (A) and the Vatican (B), manuscripts not only among the oldest extant, but wholly independent of each other; in two other important moial manuscripts ( $R$ ), and in three cursive manuscripts $(13,124,561)$; whilst the important manuscript, the Codex Ephriem (C), is here defective. They are marked with an asterisk in four uncial and six cursive manuscripts, implying a doubt as to their genuineness. They are omitted in the important Codex Brixianus (f) of the Old Latin and in some of the collices of the Sahidic and Armenian versions, and in the lately discovered Sinaitic Syrian version. There is no reference to the words in the writings of Clemens Alexandrinus and Origen, although these Fathers wonld naturally have quoted them in their controversies against Docetism. Hilary states: "In very many Greek and Latin copies," nothing was written either abont the appearance of an angel or the bloody sweat." And the same remark is made by Jerome.

2. Evidence for the genuineness of the passage.-One great argument in favour of these words is that they are contained in the Codex Sinaiticus (N), thus differing in this reading from the Codex Vaticanus, with which it in general agrees. They are also found in the celebrated Codex Bezæ (D) of the fifth century, and in ten other important uncial manuscripts, and in almost all the cursive manuscripts. The Versions are almost unanimonsly in favour of their

I In Greeis et in Latinis codicibus complurimis. 
genuineness. They are found in the Old Latin, with the exception of the Codex Brixianus (f); in the three Syriac versions, the Curetonian, the Peshito, and the Philoxenian; in the Vulgate and the Ethiopic and Armenian versions. But the elief argument in favour of their genuineness is that they are recognised in the writings of the early Fathers. Justin Martyr, in his dialogue with Trypho the Jew, thus refers to the passage: "In the Memoirs which I have said were drawn up, by His apostles and those who followed them, it is reeorded that His sweat fell down like drops of blood while $\mathrm{He}$ was praying and saying, If it is possible let this eup pass." 1 Tatian ineorporates it in his Diatessaron. Irenitus states that Jesus sweat great drops of blood, and declared that $\mathrm{His}$ sonl was exceedingly sorrowful. ${ }^{2}$ And Hippolytus, referring to the humanity of Christ, in opposition to Noetus, says: "Though God, He does not refuse the conditions proper to Him as man, since He hungers and toils and thirsts in weariness, and flies in fear, and prays in trouble. He who as God has a sleepless nature, slumbers on a pillow; He who (for our salvation) came into the world, begs off from the cup of suffering; and in an agony $\mathrm{He}$ sweats blood and is strengthened by an angel, who Himself strengthens those who believe on Him." 3 The passage is also quoted by Gregory of Nazianzus, Epiphanius, Ephraem Syrus, Chrysostom, Angustine, and subsequent Fathers. It is also said to be found in Mareion's Gospel. Epiphanius accounts for its onission from some manuscripts by the indisereet zeal of the orthodox, who onitted it because they thought that it might be perverted by heretics, and used by them in arguing against the divinity of our Lort: "orthodox persons removed it through fear, not understanding its bearing and its sreat force." But there does not appear to be any ground for this statement.

The passage hats also been objected to on internal gromnds. Thus Norton observes that the agony of Christ is represented as existing after the angel hal been sent to strengthen Him; that we have no anthority for believing

1 Just in, Dhiclog. cum Trypho, ch. ciii. 2 Adl. $H$ err. iii. 22. 2.

${ }^{3}$ Hiprolytus, Adv. Her. Noeti, ch. xriii. 
that the bloody sweat described was ever produced by mere distress of mind; and that as the disciples were asleep, it does not appear how anyone could have witnessed or become acquainted with the events related. He supposes that the passage was first written in the margin of some very early manuscript, and subsequently, through the mistake of transcribers, taken into the text of other copies. ${ }^{1}$ To the above objection it has been replied that the angel was sent, not to remove the agony, but to strengthen our Lord to endure it: and although it is said that the disciples were asleep, yet they were not so profomdly asleep but that they heard our Lord praying that the enp might pass from Him, and might have seen the bloody sweat, or the marks of it might have been apparent after its termination. The question is entirely one of external anthority, and cannot be decided by subjective impressions.

With regard to the nature of the bloody sweat, it is not said that our Lord actually sweat great drops of blood, but that His perspiration fell from Him as it were great drops

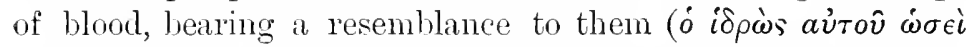
$\left.\theta \rho o ́ \mu \beta o \iota a^{\prime \prime} \mu a \tau o s\right)$. The word $\theta \rho o ́ \mu \beta o s$ is strikingly descriptive: it denotes, not simply a drop, but a great drop, such as a clot of blood. Probably Meyer gives the correct interpretation: "The sweat of Jesus was indeed no mass of blood (opposed to which is $\dot{\omega} \sigma \epsilon i$ ), but a profusion of bloody sweat, which was mingled with portions of blood, and as it flowed down appeared as clots of blood trickling down to the ground." 2 It is not correct to say, with Norton, that we have 120 authority for believing that a bloody sweat was ever produced by mere distress of mind. Instances of a bloody sweat, produced under circumstances of terror, have been recorded (Aristotle's Hist. Anim. iii. 19). "An interesting example," observes Alford, "of a sweat of blood under circumstances of strong terror, accompanied by loss of speech, is eited in the Medical Gazette for December 1848." 3

Such are the arguments against and for the genuineness of the passage containing the account of "the agony and

1 Norton, The Genuinencss of the Gospels, pp. 228, 229.

2 Commentary on Luke, in loco. $\quad{ }^{3}$ Alford's Greek Testament, in loco. 
bloody sweat." It is difficult to balance these arguments, and to come to a correct decision. The evidence from the Greek manuscripts appears to be rather at rariance with the idea of its genuineness, especially when wo consider that the combined testimony of the Alexandrian and Vatican manuscripts is unfavomable, though the force of this is to a considerable extent weakened by the passages being found in the Codex Sinaiticus. Its insertion in the Codex Beze is not conclusive, as it might be accounted for from the nature of that mamuscript, which contains many unanthorised additions. But, on the other hand, this adrerse testimony is counterbalanced by the distinct recognition of the passage by such early Fathers as Justin, Tatian, Irenreus, and Hippolytus. We judge then that the preponderance of evidence is in favour of the retention of the passage; still we camnot venture to say with Camon Cook, in words which are quoted with approval by Scrivener: "Supporting the whole passage we have an array of authorities which, whether we regard their antiquity or their character for sound judgment, veracity, and accuracy, are scarcely paralleled on any occasion." 1

The most eminent biblical critics are mostly in favour of the genuineness of the passage. It is accepted by Tischendorf, Alford, Tregelles, Meyer, and Scrivener; it is enclosed within brackets by Lachmann; whilst Westeott and Hort express their doubts by placing it within double brackets. The Reviser Version inserts it in the text withont any mark, but alds the footnote: "Many ancient anthorities onit vv. $4: 3,44 . "$

\section{Viti. Thale ani Place of Mi:itixi:}

The time when this Gospel was written has been much disputed. Dates ranging from A.D. 58 to A.D. 130 have been assigned to it. Jian fixed on A.1). 130, a date now miversally relinquished; Dr. Ditvidson, in his last edition of his Introduction to the study of the Nere Testement, fixed on A.D. 110 ;

1 Cook's Revised Version of the first three Gospls, 1. 103 ; Serivener's Criticism of the New Testement, 4thet. vol. ii. 1. 3is5. 
Pfleidlerer, on A.D. 100-120; Hilgenfeld, on A.D. 100-110; Volkmar, on A.D. 100 ; Keim and Abbott, on A.D. 80 ; Credner, De Wette, Bleek, Meyer, Holtzmann, Reuss, and Professor Sanday, after the destruction of Jerusalem ; Michaelis, Lardner, Horne, Guericke, Ebrard, and Godet, on A.I. 63 or 64. Dr. Davidson, in his earlier Introduction to the Nev Testament, (11 A.D. 61; Alford, Archbishop Thomson, and Schaff, on A.D. $5 S-60$.

Very little light is thrown on this subject from the writings of the early Fathers: their statements are at variance. But, on the other hand, an argument may be hased on the probable date of the Acts of the Apostles. The Gospel of Lnke is undoubtedly "the former treatise" to which the author of the Acts in his preface alludes: "The former treatise I made, O Theophilus, concerning all that Jesus began both to do and to teach." The Gospel, then, must have been written before the Acts. Now, the date of the Acts may, with much probability, be ascertained. The history is carried on until the close of Paul's two years' imprisonment at Rome (A.D. 63), ending with the worls: "And he abode two whole years in his own hired house" (Acts xxviii. :30). The most probable reason why Luke thus closes his history is, that he then completed it; otherwise the work would end most abruptly, without any statement of what happened after the termination of the two years. Nor is there any presumption against this opinion. Now, admitting this, we infer that the Gospel was composed before A.D. 63. In all probability, as already observed, Luke was with Panl during his two years' imprisonment in Ciesarea (A.D. 5S-60). Here he had ample opportunities for collecting the materials for his history: he met with those who had been the followers of the Lord; he could make a collection of the written Gospel fragments which were dispersed throughout the Churches; he could visit these parts of Galilee where our Lord's ministry was chiefly spent; he could go up frequently to Jerusalem; he would have ample time at his disposal; and he had free access to Paul, who, althongh a prisoner, was not kept in strict confinement, for we are informed that Felix gave order to the centurion that 
he should have indulgenee, and that none of his friends should be forbidlen to minister to him (Acts xxiv. 23). From all this we consider that the Gospel of Luke was written about A.r. 60, towarl the conclusion of Paul's imprisonment at Ciesarea.

It has been objected to this early date that there are, in the Gospel itself, statements which show that it must have been written after the destruction of Jerusalem (A.D. 70). ${ }^{1}$ In the Gospel of Matthew, it is aftirmed, the lestruction of Jerusalem is closely comnected with the end of the world. "Immediately after the tribulation of those liays" shall the final catastrophe take place (Matt. xxiv. 29); whereas, in the Gospel of Luke, a long period is interposed, termed "the times of the Gentiles": "Jerusalem shall be trodden down of the Gentiles, until the times of the Gentiles be fulfilled" (Luke xxi. 24); and it is stated that the end is not immediately (Luke xxi. 9). In Luke's Gospel the author takes a retrospect of the circumstances of the siege. "The days shall come upon thee, when thine enemies shall cast up a bank about thee, and compass thee round, and keep thee in on every side, and shall dash thee to the ground, and thy children within thee; and they shall not leave in thee one stone upon another, because thon knewest not the time of thy visitation" (Luke xix. 43, 44). But we cannot see the force of this objection. The slight variations in the accounts of our Lord's predictions of the destruction of Jerusalem in the Ciospels of Matthew and Luke are needlessly strained. In Matthew, as in Luke, there is an interval between the destruction of Jerusalem and the end of the world; the Gospel must first be eliffised thronghout the earth. "This gospel of the kingdom shall be preached in the whole world for a testimony mito all nations; and then shall the end come" (Matt. xxiv. 14). In Matthew the encompassing of Jerusalem with armies is as distinctly foretold as in Luke: the abomination of desolation was to be seen standing in the holy place (Matt. xxir. 15). And in both Matthew and Luke the statenent is male, that this generation shall not

1 This opinion was held ly Meyer, De Wrette, Crether, Bleek, and Dr. Davidis'n. 
pass away until all these things be accomplished (Matt. xxiv. 34; Luke xxi. 32). To suppose that Luke changed the prophecy of our Lord by inserting words which intimated that the prediction was fulfilled, and thus converted it into a vaticinium post excntum, is inconsistent with the honesty of the historian, and at variance with the supernatural foresight of our Lord.

If, then, the date of the Gospel was A.D. 60 , or thereby. the place of writing was Cresarea, an opinion adopted by Michaelis, Kuinoel, Schott, Thiersch, and others. Other places have been assigned. The title in the Peshito version is: "The Gospel of Luke the evangelist, which he published and preached in Greek in Alexancria the Great." Jerome fixes on Achæa and Bootia; Godet on Greece; Hug, Ewald, Zeller, Keim, and Holtzmann on Rome.

\section{The Contents of the Gospel.}

The general divisions of the Gospel are the Introduction, i. $1-4$.

1. Narrative of the birth and childhood of the Baptist and of Jesus, i. 5 -ii. 53.

2. Preparation for the ministry, iii., iv. 13.

3. Our Lord's ministry in Galilee, iv. 14-ix. 50.

4. Our Lord's ministry in Peræa and its neighbourhood, ix. 51-xviii. 14 .

5. The journey to Jerusalem, xviin. 15-xix. 48 .

6. The closing scenes and death, xx.-xxiii. 49.

7. The burial, resurrection, and ascension, xxiii. 50xxiv.

The Gospel of Luke is rich in most important additions. We have already, in a former part of this Introduction, enumerated the incidents and discourses which are peculiar to it; ${ }^{1}$ still we may recapitulate the most striking and remarkable: the annunciation and the song of the Virgin; the birth of John the Baptist and the prophecy of his father Zacharias; the angel's message to the shepherds; the presentation in the temple and the song of Simeon; the

\footnotetext{
1 See supra, p. $33 \mathrm{f}$.
} 
raising of the widlow's son at Nain; the anointing of our Lord by the woman who was a simer; the memorable and striking paralles of the Good Samaritan, the Cnjust Steward, the L'rodigal Son and the Lich Man and Lazarus, our Lord's reception of Mintlia and Mary, our Lorl's examination before Herol, and Itis appearance after the resurrection to the diseiples going to Emmans. All these passages enhance the value of the Gospel of Luke.

There are twelve important parables peenliar to Luke-

1. The Two Debtors, vii. $41-43$.

2. The Gool Samaritan, x. 25-37.

3. The Iich Man who boasted of his goorls, xii. 13-21.

4. The Janren Fig Tree, xiii. 1-9.

5. The Mamiage Feast, xiv. 7-24.

6 . The Lost I'iece of Money, xv. S-10.

7. The I'rodigal Son, xv. 11-32.

8. The Injust Steward, xvi. 1-13.

9. The Rich Man and Lazarns, xvi. 19-31.

10. The Injust Julge and the Inportunate Widow, xviii. $1-8$.

11. The Tharisee and the Publican, xviii. 9-14.

12. The Ten Pounds, xix. 12-27.

There are six miracles peeuliar to Luke-

1. The miraculous dranght of fishes, v. 1-11.

2. The raising of the widlow's son at Nain, vii. 11-17.

3 . The eure of the woman with the spirit of infirmity, xiii. $11-17$.

4. The cure of the dropsical man on the Sabbath, xiv. $1-6$.

5. The clemsing of the ten lepers, xvii. 11-19.

6. The healing of Malchus, xxii. 50, 51 . 


\title{
DISSERTATION I.
}

\author{
THE GENEALOGIES.
}

Literature. - This subject has been often discussed in separate monographs, as well as in works on the Life of Christ, and in commentaries on the Gospels of Matthew and Luke. The most important discussions are Hottinger, Dissertationes duce de genealogice Christi; Benham's Reflections on the Genectlogy of our Lord; Yardley, The Genealogy of Jesus Christ (London, 1739); Lord A. Hervey (Bishop of Bath), The Genealogies of our Lord and Saviour Jesus Christ (Cambridge, 1853), and his article on Genealogy in Smith's Biblical Dictionary; Ebrard's Gospel History, pp. 149-163 (Edinburgh, 1863); Mill's Vindication of the Gencalogies; a valuable article on Genealogy, by the Rev. Peter Holmes, in Kitto's Cyclopardia of Biblical Literature, 2nd ed. (Edinburgh, 1869); Wieseler's Beiträge aur Wurdigung der Evangelien, 1869; Andrews, Life of our Lord, pp. 56-70, new edition (Edinburgh: T. \& T. Clark, 1893), where the subject is well stated; Greswell's Dissertations on the Harmony of the Gospels; Dissertation ii. On the two genealogies, vol. ii. pp. 111-118; also the commentaries of Meyer on Matthew and Luke; Farrar on Luke in the Cambridge Bible for Schools; Godet on Luke (translation, Edinburgh, 1875); Morison on Matthew (London, 1883); Mansel on Matthew in Speaker's Commentary; and Schaff's Popular Commentary on the Now Testament.

The reconciliation of the genealogies given in Matt. i. 1-17 and Luke iii. $23-3 \mathrm{~S}$ is a matter of considerable difficulty. Both profess to be the genealogies of our Lord ; that of Matthew is introduced by the words: "The book of the generation of 
Jesus Christ"; whilst in the Gospel of Luke the introdnetory words are: "Jesus Himself, when He began to teach, was abont thirty years of age, being the son (as was supposed) of Joseph"; but they are almost entirely different, being written from different points of view. In Matthew the genealogy eommences with Abraham, the father of the Jewish nation, probably beeanse his Gospel was written mainly for Hebrew Christians; whilst in Luke it closes with Adam, the father of the human race, probably because his Gospel was written for Christians generally, whether Jews or Crentiles. The genealogy of Matthew descends from Abraham to Joseph, the husband of Mary, by tracing the line of descent from father to son; whilst that of Luke ascends from Joseph to Adam, by tracing the line of aseent from son to father. Matthew

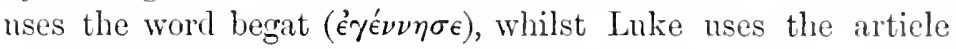
$\tau o \hat{v}$, the genitive of relationship, translated in our version the son of. From Abraham to David the evangelists give the same genealogieal series; but after David they diverge. Matthew gives the royal lineage in the line of Solomon to the eaptivity, whilst Luke gives the genealogy in the line of Nathan, another of the sons of David. The genealogies meet in the middle in the persons of Shealtiel and Zernbbabel (Matt. i. 12 ; Luke iii. 27), but again immediately diverge, until they eonverge in Joseph, the husband of Mary.

Varions opinions have been formed of these genealogies with reference to their diversities and apparent contradictions. Dean Alford supposes that a solution of the diffieulties is impossible from want of suffieient clatit. "It is," he observes, "quite beside the purpose of the present commentary to attempt to reconeile the two. It has never yet been aceomplished; and every endeavour to do it has violated either ingenuousness or common sense." 1 On the other hand, Professor Norton and others affirm that the genealogies, and more particularly that given by Matthew, are interpolations. The first two chapters of Matthew's Gospel, observes Professor Norton, "may liave been an aneient docunent, written in Hebrew, originally a separate work, but which, on account of its small size and the eonnection of its subjeet, was trunseribed

${ }^{1}$ Alford's tirele Testement, 1. 473, last enlition. 
into manuscripts of the Hebrew original of Matthew." ' The external evidences for the exclusion of the genealogies are weak, amounting only to this, that they are omitted in the Gospel of Marcion and in the Diatessaron of Tatian ; ${ }^{2}$ whilst they are contained in all Greek manuscripts and versions. But the internal evidence is rather in favour of their exclusion. They may be omitted without any interruption in the narrative. Thus the Gospel of Matthew would commence with the words: "Now the birth of Jesus Christ was on this wise" (Matt. i. 1S); whilst in Luke the temptation of Christ would be directly connected, as in the other Gospels, with His baptism and the descent of the Holy Ghost (Luke iii. 22, iv. 1). Besides, the apparent or real inaccuracies in the genealogy as given by Matthew, to which we shall afterwards advert, are presumptions unfavourable to its genuineness. Still the external evidence in favour of them is so strong that, by the critical rules which must govern our judgment, their insertion, as forming an original part of the Gospels of Matthew and Luke, must be admitted.

This may be the place to advert to the important recent discovery by Mrs. Lewis, in the monastery of Mount Sinai, of a Syrian manuscript of the four Gospels. Chiefly by her learning and indefatigable labour this Syrian version has been transcribed and published along with a translation. ${ }^{3}$ The manuscript is a palimpsest, the lives of female saints being written over it. Mrs. Lewis twice visited the monastery of Mount Sinai in 1892 and 1893, and, assisted by several eminent English scholars, was enabled to obtain a transcription of the manuscript. It is affirmed to be probably a variant copy of the Curetonian Syriac, fragments of which were brought to this country by Archdeacon Tattam in 1842, ${ }^{4}$ and which is now

1 Norton, The Genuineness of the Gospels, vol. i. p. 204.

2 The omission of the genealogies in the Gospel of Marcion is of no importance, as Harcion mutilated the Gospel of Luke; lut it must be admitted that the omission in Tatian's Diatessaron is of some weight, but it is unsupported.

3 The Four Gospels in Syrice. Transcribed from the Sinaitic Palimpsest. Cambridge, 1894: Translation of the Four Gospels from the Syriac of the Sinaitic Palimpsest, by Agnes Smith Lewis. London, 1894.

${ }^{4}$ It was not published until 1858, under the title, "Remains of a very 
generally admitted to be the oldest Syriac version, of which the Peshito is mly a recension, bearing the same relation to it as the Vulgate does to the old Latin. ${ }^{1}$ If this is the case, this newly disewered mannscript must be regarded as of great injortance, as supplying most of the lacunie in the Curetonian version, and nearly completing it. The recently discovered mannscript is of meertain date. It agrees generilly with the oldest uncials, the Vatican, and the Sinaitic; as, for example, it wants the concluding verses of Mark's Gospel and the account of the bloody sweat in Lulie.

It has been suggested that this Syriac manuscript has an inportant hearing on the question of the gencalogies, especially in regard to the genealogy in Matthew:" In its record of the birth of Christ the new manuscript is Ebionite and heretical. Whilst it testifies to the supernatural nature of His birth in the same terms as in Matt. i. 18 and 23 of the received text, at the same time it inconsistently asserts that He wits the son of Joseph. Thus ver. 16 is: "Joseph, to whom was betrothed Mary the virgin, begat Jesus, who is called the Christ"; ver. 21 is: "And she shall bear to thee a son, and thou shalt call His name Jesus"; and in ver. 24 it is sairl: "When Joseph arose from his sleepl he did as the angel of the Lord commanded him, and took his wife: and she lore to him it son, and he called His name .Jesus."

The genealogy in luke is inperfect in the new mannseript, and it is difficult to say how far it algrees with or differs from the genealogy in the received text.

ancient recensime of the Fon Gospels in Syriac, hitherto mbinown in Euroje, discovererl, editerl, and translated by Willian C'ureton, D.D., Camon of Westminster. Lomelon, 1858."

ISo Ewall, Bleck, Alford, Tregelles, Hort. Seriveluer, lowerer, takes an olposite viuw (Introlution to the Criticism of the N.T. vol. ii. p. 16 1F.).

2 The fragunents of the Curetonian syriac bonght to England by

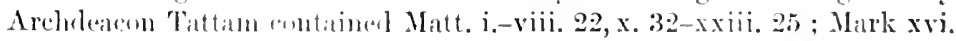
17-20; luke ii. 18-ii. 16, vii. 33-xvi. 12, xvii. 1-xxir. 44; Johm i. 1-42, iii. 5-viii. 19, xiv. 10-12, 15-19, 21-23, 26-29.

${ }^{3}$ See a series of lettrors in the Aredemy from November 1894 to Marel 1895); and in impertant artiche (1n the sulject by Archleacon, now Dean, Farrar in the Eipusitur for Jamuary 1895. 
The importance of the manuscript on this point has, we consider, been greatly overestimated. There is 110 ground for suggesting that the genealogy in the new manuscript can be substituted for that contained in Matthew's Gospel. ${ }^{1}$ Its peculiar Ebionite readings stand alone, and are supported by no manuscript nor version. Even the Curetonian Syriac is adverse, as it contains the received readings. The only manuscript which appears to favour them is the Latin Codex Bobbiensis; but even it only to the extent of omitting the words: "And knew her not till she brought forth her son." Against this overwhelming mass of evidence it is impossible to defend the peculiar readings found in this maunseript; they never could have formed a part of the original text. The genealogy of Matthew may have been a separate docnment incorporated into this Gospel, but it could not in its original form have contained the readings found in the Sinaitic Syriac version.

The divergences in the genealogies may be seen from the following table:-

I. AdAM to ABRAH.M.

Not given in Matthew. Luke iii. 3t-38.

II. Abrahay to David.

Same in both Gospels-Matt. i. 1-6 ; Luke iii. 32-3t.

III. DAvid to JesUs Christ.

Matt. I. 7-16.

Solomon by the wife of Uriah. Rehoboam.

Abijah.

Asa.

Jeloshaphat.

Joram.
LuKE III. Р3-31.

Nithan.

Mattatha.

Nemna.

Nelea.

Eliakim.

Joman.

1 The Rer. Mr. Charles, in one of his letters to the Ardemy (Dec. 1, 1894), expresses his opinion that the new manuscript furnishes the key to the problem raised by the variations in the two genealogies. If we understand him aright, he seems to think that the genealogy of Watthew as given in the new manuscript was the form of the original document, and that at a very early period it was altered in the interests of orthodoxy and attached to our canonical Gospel. 


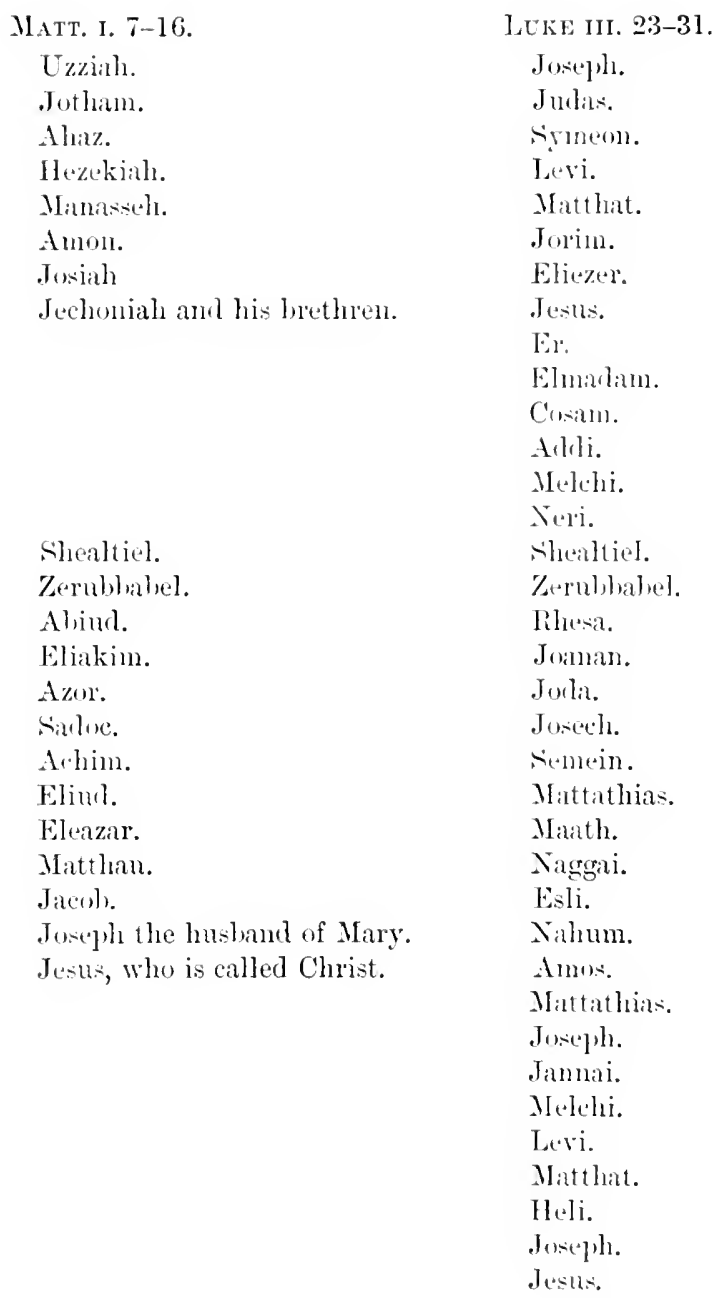

Before attempting the reconciliation of the grenealogies, it may be anvisalle to consider some peculiarities and apparent mistakes or discremancies in the genealogy given by Matthew.

The genealogy from Salmon to David is given as Salmon, Joaz, Obed, Jesse, David (Matt. i. 5), and the lineage is the same in Luke's genealogy (Luke iii. :32). Thus there are only four generations, Buaz, Obed, Jesse, and lavil, between 
Salmon and David. Nahshon, the father of Salmon, is mentioned as the prince of the tribe of Judah in the time of Moses (Num. i. 7, vii. 17); and, accordingly, Salmon, the husband of Rahab, must have been a contemporary of Joshua. But the interval between Salmon and David, filled up by these four generations, according to the calculations made from the Book of Judges, must have been 400 or 450 years. This period is also given by St. Paul in his speech in Pisidian Antioch: "And when He had destroyed seven nations in the land of Canaan, He gave them their land for an inheritance for about 450 years" (Acts xiii. 19). It also corresponds with the chronology of Josephus. Either the period assigned is too long, or several names must have been onitted. The probability is that the number 450 was assumed by the Jews by adding together the years of the judges and of the servitudes as mentioned in the Book of Judges; ${ }^{1}$ whereas it is probable that several of the judges were contemporaneous. ${ }^{2}$ The community of Israel appears at that time to have been divided into three confederacies: Judah and the south, Ephraim and the north, and the land of Gilead beyond Jordan. The enumeration of four generations given by Matthew is corroborated not only by Luke, but also by the Book of Ruth (Ruth iv. 20, 21) and by the first Book of Chronicles (1 Chron. ii. 11, 12). ${ }^{3}$

In Matthew's genealogy three kings are omitted. It is stated that Joram begat Uzziah (Matt. i. 8); whereas the genealogy ought to have been Joram begat Ahaziah, and

${ }^{1}$ Hervey, On the Genectoyies, 1'p. 220, 221, 252. The years of the judges from Othniel to Eli are 339, and of the servitudes 111 : in all 450 . See Biscoe, On the Acts, p. 605.

2 This sulbject is rery elahorately discussed by Bishop Hervey in ch. ix. on the discordance between the genealogy from Salmon to Davirl, and the received chronology of the corresponding period, pp. 204-276. He supposes that Ehud, Gideon, and Jephthah were contemporary, and that the era of the judges, instead of lasting 450 years, extended only to four generations. This abbreviation of the time corresponds with the records of Egyptian history.

${ }^{3}$ Another solution is that in the genealogy from Salmon to David some names are omitted; and others think that Rallab, the mother of Boaz, was a different person from the Rahab mentioned in the Book of Joshna. 
Ahaziah begat Joash, and Joash begat Amaziah, and Amaziah begat Uzziah. Thus three kimgs are omitted, namely, Ahaziah, Joash, and Amazialı. The most plausible explanation of this omission is that it arose from a mistake of the transcriber. The first name onitted is Ahaziah, in Greek 'Oxoy'av, which is identical in the last three syllables with 'OYiav, the next name mentioned; and it is supposed that the transeriber, his eye catching the conclusion of the word, overlooked the first syllable, ' $O \chi$, and the intervening names, and so wrote 'OYiav as following Joram. ${ }^{1}$ But the authority of all manuseripts is against this supposition, except perhaps the Codex Bezre. In that codex the first chapter of Matthew, containing the genealogy, is wanting; but the genealogical list of Matthew from David to Joseph is incorporated in the third chapter of Luke with the names of the three omitted kings inserted. The omission of these names does not, of course, affect the validity of the genealogy: it is not necessary that all the links should be named.

Another king is omitted, namely, Jehoiakim. It is said: "Josiah begat Jechoniah and his brethren, at the time of the carrying away to Babylon. And after the carrying away to Babylon, Jechoniah begat Shealtiel" (Matt. i. 11, 12); whereas in reality Josiah was the father of Jehoiakim, and Jehoiakim the father of Jechoniah or Jehoiachin. Bishop Hervey supposes that the reading in Matthew originally was:

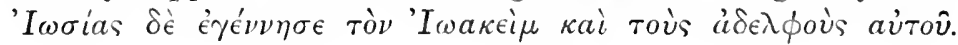

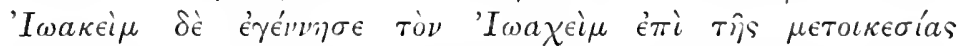

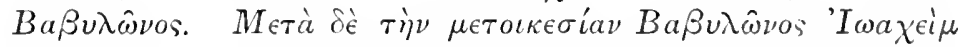

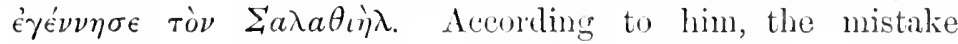
arose from the similarity of names, the transeriber having written $\chi$ in the first name insteal of $\kappa .^{2}$ This realing is supported by the Codex Pezae, by two uncial manuscripts of the tenth century, $\mathrm{M} \mathrm{U}$, by thinty cursive manuscripts, by

1 The insertion of the nanes of these three kings would remer the

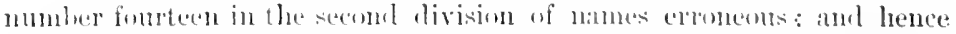

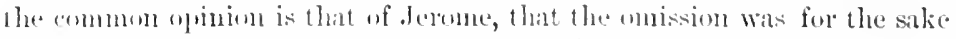

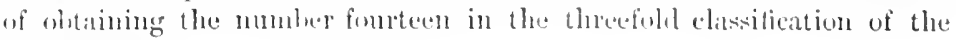
genealogies.

2 Ilerey, Geneuloyies, 1. 73. 
several Syriac manuscripts, and by Irenæus, who says: "Joseph is shown to be the son of Joachim and Jechoniah, as also Matthew sets forth in his pedigree." ${ }^{1}$ It is inserted by Henry Stephens in his editions of the Greek Testament, published in 1576 and 1584. And in a marginal note in the Authorised Version it is said: "Some read Josias begat Jakim, and Jakim begat Jechonias." But such a reading cannot be admitted, on account of the preponderating weight of contrary testimony. Dr. Morison supposes that the Jechoniah in ver. 11 is different from the Jechoniah in ver. 12, and that the name was common to both father and son. In ver. 11 by Jechoniah is meant Jechoniah I. or Jehoiakim the son of Josiah, and in ver. 12 by Jechoniah is meant Jechoniah II. or Jehoiachin the son of Jehoiakim. ${ }^{2}$

There is also a difficulty in the classification of Matthew's genealogies. "So all the generations, from Abraham unto David, are fourteen generations; and from David, unto the carrying away to Babylon, are fourteen generations; and from the carrying away to Babylon unto the Christ, are fourteen generations" (Matt. i. 17). The genealogy is arranged in three divisions, each containing fourteen generations. The first division, from Abraham to David, is the same as the list given by Luke, and contains exactly fourteen generations. The second division, from Solomon to the Babylonish captivity, also contains fourteen names; but if the four kings omitted were included, the number would be eighteen. In the third division, from the Babylonish captivity to Christ, Jechoniah must be again included to complete the number. ${ }^{3}$ The periods are of very mequal length. The first series, from Abraham to David, inchudes a period of upwards of 900 years; the second series, from Solomon to the Captivity, including the reign of the four kings omitted, is 416 years; and the third series, from the Captivity to Christ, is 617

${ }^{1}$ Adv. Her. iii. 21. 9.

2 Morison's Commentary on Mutthew, on Matt. i. 11.

${ }^{3}$ On the arrangement of the names in these three divisions, and the necessity of including Jechoniah both in the second and third divisions, see Meyer on Matthew, vol. i. pp. 58, 59. If Jechoniah be reckoned only once, we have only thirteen generations in the last series. 
years. It is also to be observed that supposing Shealtiel and Zerubbabel to be the same persons in both genealogies, the number of generations given in Matthew differs from that given in Luke. In Matthew the nmber from Solomon to Shealtiel is fourteen, or, inchrding the omitted kings, eighteen ; the number given by Inke is twenty, which, however, is not a great variation. But the number of generations from Shealtiel to Christ in Matthew is fourteen, whereas in Luke it is twenty-two, which can only be explained on the supposition that several names have been omitted by Matthew; or that Shealtiel and Zernbbabel are not the same persons in the Gospels of Matthew and Luke.

In Luke's genealogy there is only one peculiarity which requires to be noticed. The first portion, from Actam to Abraham, not given by Matthew, is the same as the genealogy given in Genesis, with the exception that Cainan is mentioned as intervening between Shelah and Arphaxad (Luke iii. 36). No such name occurs in the Hebrew or in the Samaritan Pentatench; but it is found in the Septuagint, and as Lnke wrote in Greek, his genealogical list was, donbtless, taken from that version. Of course, the Cainan here mentioned as the son of Arphaxad is different from the Cainan who is mentioned in the subsequent verse (Luke iii. 37 ) as the son of Enos, and whose name occurs in the Mosaic chronology (Gen. v. 9, 10).

In comparing the genealogies, a great difficulty arises from the fact that after they had branched off for at least eighteen generations, the one in the line of Solomon and the other in the line of Nathan, they meet again, after the lapse of four centuries, in the persons of shealtiel and \%erubbabel (Matt. i. 12, 13; Luke iii. 27). It is generally taken for granter that these persons are identical in both genealogies, and are the same as those mentioned in the later books of the Old Testament. This junction of the senealogies is generally acconnted for on the supposition that the royal line of Solomon becane extinct in Jehoiachin at the Babylonish eaptivity, and that Shealtiel, the son of Neri

1 Mansel supposes that it leeame extinct in the time of Ahar, and

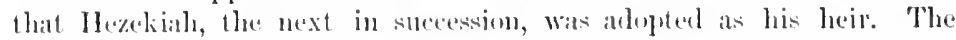


was the next in succession in the regal line. It is asserted that, according to the prediction or statement of Jeremiah, Jehoiachin should be childless: "Thus saith the Lord, Write ye this man (Coniah, that is, Jehoiachin) childless, a man that shall not prosper in his days: for no man of his seed shall prosper, sitting upon the throne of David" (Jer. xxii. 30). But these words do not absolntely affirm that Jehoiachin should have no children, but merely that no descendant of his should sit on the throne of David. Several sons of Jehoiachin are mentioned in the Book of Chronicles, and among them Shealtiel, or, as he is otherwise named, Salathiel (1 Chron. iii. 17, 18); so that the statement that Jechoniah begat Shcaltiel is corroborated by the Old Testament. Zerubbabel is called the son of Shealtiel, and this is also stated in the Books of Ezra and Nehemiah, and in the prophecies of Haggai (Ezra iii. 2, 8 ; Neh. xii. 1; Hag. i. 1, 12,14 , ii. 2): whereas in the Book of Chronicles he is called the son of Pedaiah, the brother of Shealtiel (1 Chron. iii. 19), which may be accounted for on the supposition that, as his nephew, he became his heir and successor in the royal line. The names of seven sons and two grandsons of Zerubbabel are given in the Book of Chronicles (1 Chron. iii. 19, 20), but among them occurs neither Abiud, the son of Zerubbabel, according to Matthew (Matt. i. 13), nor Rhesa, his son, according to Luke (Luke iii. 27). But the question arises, Are we justified in assuming that the Shealtiel and Zerubbabel in Matthew are the same persons as those mentioned in Luke? In Matthew they occur as members of the royal line of Solomon; in Luke, as members of the unknown line of Nathan. The Zerubbabel of Matthew is undoubtedly the governor of the Jews, the grandson of Jehoiachin mentioned in the later books of the Old Testament. Their position in the genealogical line favours their identity; as

reason for this is that Ahaz died at the age of thirty-six, so that unless there be some error in the numbers, Ahaz was but eleven years older than Hezekiah. Speaker's Commentary on Matthew, vol. i. p. 4. Calvin goes further, and supposes that the Solomonic line became extinct on the death of Ahaziah; and that Joash is only called the son of Ahaziah because he was his nearest relation, and the direct heir to the crown. 
according to Matthew there are eighteen generations between Solomon and Shealtiel, and according to Luke twenty generations between Nathan and shealtiel. But apart from this, and the coincidence that Shealtiel was the father of Zerubbabel, there is no reason to suppose that they are the same persons. It is altugether improbialble that after eighteen generations and the lapse of four centuries the genealogies should meet in the same persons, and again immediately branch off. May it not be that we have here two entirely different persons: the Shealtiel and Zerubbabel, the descendants of Solomon, in Matthew, being those mentioned in the later books of the Old Testament; and the Shealtiel and Zerubbabel, the descendants of Nathan, in Luke, being otherwise unknown persons? This is the view arlopted by Wieseler and Bleek as the most probable solution of the difficulty. The occurrence of these persons in both lists, the one the father and the other the son, and their nearly identical position in the genealogies, are certainly serious objections to this view; but whatever view we adopt there is a difficulty, and perhaps the conjecture that these names stand for different persons is after all the most probable solution.

Three theories of reconciliation have been advanced to bring these genealogies into accord: the theory of a levirate marriage, the theory that both Matthew and Luke give the genealogy of Joseph, and the theory that whilst Matthew gives the genealogy of Joseph, Luke gives the genealogy of Mary. The first and second theories may be combined.

The hypothesis of a levirate marriage proceeds on the assumption that Jacol was the father of Joseph by a levirate marriage, and that Heli was his real father: or, conversely, that Jacol, was. Joseph's real father, and Heli his putative or legal father. Aceording to the Mosaie law, it was enjoined that if one of two brothers died having no chillyen, his hrother should take his wife, and the firsthorn should suceeed to the deceaserl hrother (1)ent. xxv. 5, (5). It is supposed that such a case occurred here. Jalcols and Heli were brothers, and the one married the wirlow of the other; Matthew gives the enenealogy of Jacol, the legal father of Joseph, and Luke that of Heli, his real father ; or conversely. 
This was the early solution advanced by Julius Africanus, about the middle of the third century, as recorded by Eusebius. ${ }^{1}$ The following is the statement of Eusebius, given in a somewhat abbreviated form: Matthew and Luke in their Gospels have given the genealogy of Christ differently, and many suppose that they are at variance. We subjoin the account of the matter which is given by Julius Africanus in his Epistle to Aristides, in which he discusses the harmony of the Gospel genealogies. After refuting the opinions of others as forced and deceptive, he gives the following account which he had received from tradition. The names of the generations were reckoned in Israel, either, according to nature, by the succession of legitimate offspring, or, according to law, whenever another raised up a child in the name of a brother dying childless. Some are inserted in the genealogical table who succeeded each other by natural descent of father and son, and some who were born of others: both the real and the reputed fathers are here mentioned. Thus neither of the Gospels has made a false statement, for the one reckons by nature and the other by law. So that both accounts are strictly true, and come down to Joseph with considerable intricacy indeed, but quite accurately. If we reckon the generations from David through Solomon, the third from the end is found to be Matthan, who begat Jacob the father of Joseph; but if, with Luke, we reckon them from Nathan the son of David, in like manner the third from the end is Melchi, ${ }^{2}$ whose son Heli was the father of Joseph. It must be shown how each is recorded to be the father of Joseph, both Jacob who derived his descent from Solomon, and Heli who derived his from Nathan. Jacob and Heli were brothers, and their fathers, Matthan and Melchi, although of different families, are declared to be grandfathers of Joseph. Matthan and Melehi, having married in succession the same woman, begat children who were uterine brothers. By Estha, for this was the woman's name according to

\section{${ }^{1}$ Hist. Eccl. i. 7.}

${ }^{2}$ In our text of Luke's Gospel Matthat and Levi intervene between Melchi and Heli (Luke iii. 24). Probably the text which Julins Africanus followed omitted these names. 
tradition, ${ }^{1}$ Matthan, a descendant of Solomon, first begat Jacob; and wlen Matthan was dead, Melehi, who traced his descent back to Nathan, heing of the same tribe but of another fannily, married her, and heagit Heli. Thus we shall find the two, Jacob and Heli, althongh belonging to different families, were yet brethren by the same nother. Of these the one, Jacob, when his brother IIcli hat died childless, took the latter's wife, and begat by her a son, .Joseph, his own son by nature. Wherefore also it is witten Jacob begat Joseph (Matt. i. 16). But according to law he was the son of Heli. Accordingly Luke says: "Who was the son, as was supposed, of Joseph, the son of Heli, the son of Melchi" (Luke iii. $23,24)$; for he could not more clearly express the generations according to law.

Accorling to this explanation the genealogy would be-

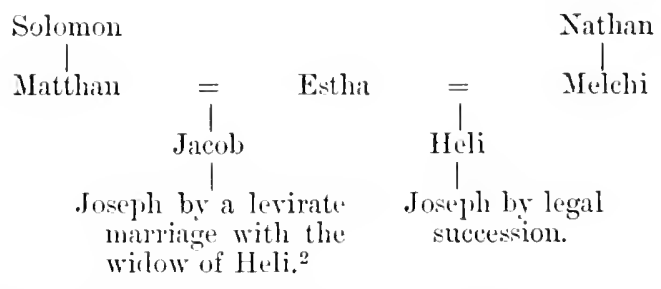

Matthew grives the genealogy of Jacol, and Luke that of Heli.

This theory is intricate, and bears the aspect of a hypothesis framed to remore a difficulty. Besiles, the son of a levirate marriage was always called the son of his real father, and not of his legal father. Thus, for example, Obed is eallerl the son of Boaz, and not the son of Mahlon, whose widow he married as being next of lin. The levirate eustom or law of marriage appears to have heen concerned with the peculine law of heritage among the . Jews. This hypothesis may remove the diflienlty arising from two listinct genealogical lines: lut as both of these are connected with

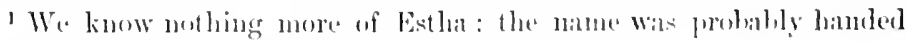
down hy tratition from the erandsons of Jule, the lorother of the Lord, mentioned in this patsinge by Julius Africanus.

2 Ser Farmar on Lulie, 1. 392. 
the descent of Joseph, the one his legal and the other his real descent, they cannot properly be considered as genealogies of Jesus, who was only supposed to be the son of Joseph; an objection which we shall more fully consider.

The secoud hypothesis is that both Matthew and Luke give the genealogy of Joseph, neither of them giving the genealogy of Mary. This hypothesis has been adopted with some variations by Calvin, Grotius, Hug, Winer, Bleek, De Wette, Meyer, Bishop Hervey, Dr. Morison, Mansel, ${ }^{1}$ Dr. Samuel Davidson, Alford, Bishop Wordsworth, Carr, ${ }^{2}$ Bishop Ellicott, ${ }^{3}$ M'Clellan, Farrar, ${ }^{4}$ and Geikie. According to this hypothesis, Matthew gives the royal line of succession from Solomon to Joseph, whilst Luke gives the natural or lineal line from Nathan to Joseph. Their conjunction in Shealtiel and Zerubbabel is generally explained on the supposition that the royal line failed in the person of Jehoiachin, as he, according to the prediction of Jeremiah, had no children, and that Shealtiel and Zerubbabel, descendants from Nathan, succeeded as the heirs of Solomon. This may account for the difference of names from David to Zerubbabel, but does not account for the difference of names between Zerubbabel and Joseph. ${ }^{5}$

The great, and to us insuperable, objection to this theory

1 Speaker's Commentary.

2 Commentary on Matthew: Cambridye Bible for Schools; p. 29.

${ }^{3}$ Historical Lectures on the Life of our Lord, 3rd ed. 1. 96, note.

* Farrar On Luke, Excursus ii.: "The Double Genealogies of Christ as the Son of David," p1. 369-375.

5 Attempits have been made to prove that several of the names that occur after Zerul,babel are merely variations of the same name. Rhesa, the son of Zerubbabel, according to Luke (iii. 26), is supposed not to be a proper name, lont an aplellative signifying a head or chief, applied to Zerublabel as the prince of the Captivity. Alsind (Aßrovo) in Matt.i. 13, and Joamma ('I Zerulbabel, are regarded as the same name. After this it is smpposed that the lines again diverge from Aljind and Joanna; Mattlew gives the elder lranch from Eliakim, probably the eldest son of Abiud, and Luke from Joda a younger branch. It is further supposed that the genealogies meet again in Matthan, who on the failure of Eliakim's line became the head of the house of David. See Herrey's Genealoyies, pp. $115 \mathrm{ff}$. and 1. 343 . 
is that neither of the genealogies gives that of Jesus. Jesus was, according to both Matthew and Luke, by reason of His miraculous birth, only the supposed son of Joseph and the real son of Mary. ${ }^{1}$ We have then according to this theory, so far as the genealogies are concerned, no proof that Jesus was the son of David. The Davidic descent of Jesus is repeatedly affirmed in Scripture. The title which the Jews applied to the Messiah, "The son of David," and the predietions of the prophets, that "a Branch should arise from the root of 1)avid," all imply His Davidic descent; but unless Mary were descended from David, this could not be the case. Peter, in his discourse on the Day of P'entecost, aftirms that of the fruit of the loins of I)avid, according to the flesh, God would raise up Christ to sit upon his throne (Acts ii. 30). Paul, in his discourse in Pisilian Antioch, makes the same declaration, that of the seed of David, God, aceording to His promise, raised unto Israel a Saviour, Jesus (Acts xiii. 23). In his Epistles he twice affirms the Davidic descent of Jesus: "Jesus Christ our Lord was made of the seed of David according to the flesh" (Rom. i. 3). "Jesus Christ, of the seed of l)avid, was raised from the dead" (2 Tim. ii. 8). And in the Apocalypse our Lord is ealled "the root and the offspring of David" (Rev. xxii. 6). But no eonclusion of this nature can be drawn from the Davidic descent of Joseph, and consequently the gencalogies, if they refer to Joseph only, do not prove that our Lord was descended from David. They are divesterl of their importance and interest. The Davilie descent of Mary is asserted by the Fathers, as Justin Martyr (Jiral. c. Tryph. xh.), Irenielus (Ade. Her. iii. 21. 5), Tertullian, and others. As Meyer says: "The Davidie descent of Jesus is established as certain ly the preclictions of the prophets, whieh, in reference to so essential a mank of the Messiah, conld not remain withont fulfilment, as well as by the manimoms testimony of the New Testament." "2

This oljection is thus met by Bishep Hervey: "If the

1 Matt. i. 18 ; Luk+ iii. 35.

"Neyer's fommentury on Watther, vol. i. 1) 6il. At the same lime, Meyer asserts that there is mo evidence of this from the genealegies, as acesteding to him the genealogy in Juke is mot that of Mary. 
Matthan of Matthew is the same individual as the Matthat of Luke, it follows that Jacob and Heli were brothers. And if Mary were the danghter of Jacob, and Joseph the son of Heli, Joseph and Mary would be first cousins, grandchildren of the same grandfather Matthat. And if Jacob had no son, but only daughters, and his male heir and successor, as head of the tribe of Judah, were Joseph the son of his brother Heli, we are quite sure, from the constant practice of the Jews, that Joseph would marry Mary; just as the five daughters of Zelophehad married their five cousins." 1 But such an answer to the objection cannot be maintained; it is founded not on one, but on four suppositions, not one of which can be proved.

The third hypothesis is, that whilst Matthew gives the genealogy of Joseph, Luke gives that of Mary. This theory has been adopted by Luther, Dr. John Lightfoot, Hottinger, Bengel, ${ }^{2}$ Kidder, Kuinoel, Michaelis, Yardley, $\mathrm{M}^{\circ} \mathrm{Knight,}$ Greswell, ${ }^{3}$ Lange, ${ }^{4}$ Auberlen, Wieseler, Ebrard, ${ }^{5}$ Holmes, ${ }^{6}$ Olshausen, ${ }^{7}$ Smith of Jordanhill, Dean Spence, Andrews, ${ }^{8}$ Plumptre, Schaff, ${ }^{9}$ Godet, ${ }^{10}$ and Weiss. ${ }^{11}$ According to this theory, Jesus is by the genealogy of Matthew shown to be the legal heir of David's throne, whilst by the genealogy of Luke He is shown to be the seed of David according to the flesh, by His being the son of Mary. The genealogy of Matthew is the genealogy of Joseph, whilst the genealogy of Luke is that of Heli. Mary's name is omitted in the genealogy, because it was not the custom of the Jews to mention women in their genealogical tables. That in one of the genealogies the descent of Mary is

${ }^{1}$ Hervey's Genealogies, p1) 56, 57.

${ }^{2}$ Bengel's Gnomon of the New Testament on Matt. i. 16.

${ }^{3}$ Greswell's Dissertutions, vol. ii. p. 103.

${ }^{4}$ Lange's Life of Christ, vol. i. p. 380, translation.

5 Elorard's Gospel History, 1) 159.

"Kitto's Cyclopediu, article, "Genealogy."

‘ Olshausen, On the Gospels, vol. i. 1. 39.

' Andrews' Life of Christ, 1. 56.

9 Schaff" on "Matthew" in the P'opular Commentary on the New Testument.

10 Godet's Commentary on Luke, vol. i. p. 201, translation.

11 Weiss' Life of Jesus, vol. i. p. 220, translation. 
given, is affirmed by Clemens Alexandrinus, although he fixes, as we think erroneously, on that given by Matthew. "In the Gospel aceording to Matthew the genealogy which is begun with Abraham is continued down to Mary the mother of our Lord." 1 Ant it is a emrous eiremnstince that in the Tahmul, Mary the mother of Jesus is called the daughter of Heli,-a statement which enuld only be made from Luke's Gospel, or more probably from tradition.2

bit here we are met with what aplears to be a formilable objection: that as it is distinctly stated by Matthew that Joseph was the son of Jacob, so it is as distinctly stated by Luke that he was the son of Heli. It is not disputed that Joseph was the son of Jacob; the words are clean, "Jacob begat Joseph the husband of Mary, of whom was born Jesus, who is called Christ" (Matt. i. 16). But that Joseph was the son of Heli is not so distinctly stated. Acerding to the best

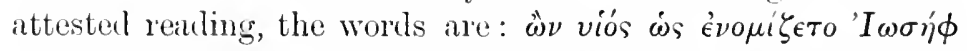
$\tau o \hat{v}$ 'H$H \epsilon i$, rendered in the Revised Version: "Being the son (as was supposed) of Joseph the son of Heli" (Luke iii. 2:3). But the parenthesis may be properly extended so that the words might be read: "Being (the son as was supposed of Joseph) the son of Heli." According to this reading, the meaning might be that Jesus was the supposed son of Joseph, but through His mother Mary, onitted in the genealogy as women are, the real son or grandson of Heli. Besides, it is to be remarked that the artiele rov is omitted bofore the name Joseph, whilst it is to be fouml before all the other names belonging to the genealogieal series. From this it may be inferred that the name Joseph belongs to the parenthetical clause introhnced by luke; so that the genitive $\tau o \hat{v}$ ' $H \lambda \in \imath^{\prime}$ depends, not on Joseph, but on $\ddot{\omega} \nu$ : Jesus, as was supporsed, the sem of . Joseph, being the son of Heli. It is not meommon in the Old Testannent for the grandson to he ralled the son of

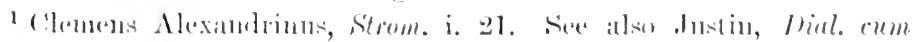
Trymhon. rh. ('x).

"2'heterig. 77. 1. (

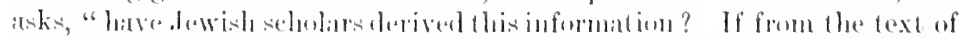

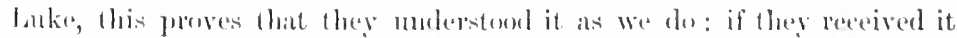

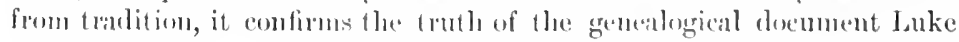
matile nice of." 
his grandfather. Thus, if this explanation be adopted, the genealogy given by Luke is not that of Joseph, but of Heli the grandfather of Jesus. ${ }^{1}$

We conclude that this is the true solution of the problem - the reconciliation of the genealogies of our Lord as given by Matthew and Luke. We have not here the genealogy of the same person, for if this were the case, the difference in the names, so far as we ean see, wonld be irreeoneilable, except by a series of improbable suppositions; whereas if they are the genealogies of different persons, then the difference in the names is not only aecountable but necessary." And, also, whereas on the hypothesis that both genealogies refer to Joseph, there is no evidence that Jesus was deseended from David; on the other hypothesis that one of the genealogies refer's to Mary, it is proved that Jesus was of the seed of David aceording to the Hesh.

But it has been objected to the whole subjeet, that it is very improbable that there should exist such long genealogieal registers, especially of persons such as Joseph and Mary, who, according to the Gospels, were of humble origin, and that both of them could trace their deseent from David. But this objection is met by the fact of the scrupulous earefulness of the Jews with regard to their genealogies. We have abundant evidence of this in the First Book of Chronieles and in the Books of Ezra and Nehemiah. Josephus frequently refers to the public tables. In the accomnt of his life, after giving his own priestly descent, he says: "Thus have I set down the genealogy of my family as I have found it deseribed in the

1 See Godet, Commentary on Luke, vol. i. p. 199. He draws the following conclusions from the omission of $\tau o \tilde{\nu}$ : 1. That this name (Joseph) helongs rather to the sentence introrluced by Luke. 2. That the genealogical document which he consulted began with the name of Heli. 3. And conseruently that this piece was not originally the genealogy of Jesus or of Joseph, but of Heli. Since the above was written, we have found the same thenry proposed ly Professor Roberts of St. Andrews in an article in the Thinker, Jamuary 1895.

2 According to this view, the Shealtiel and Zerubbabl of Matthew, the first the son and the second the grandson of Jehoiachin, were the well-known persons in the Old Testament, whilst the Shealtiel and Zerubbabel of Luke are two unknown persons. 
public tables." And he informs us that from all countries in which their priests are seattered abroad, they send to Jerusalem the names of their parents, attested by witnesses. ${ }^{1}$ The famous Rabbi Hillel, a contemperary of our Lord, succeeded in proving by means of sencalogieal tables that, although a poor man, he was a descendant of David. Rabbi Levi says: There was found a book of gencalouries at Jerusalem in which it was written that Hillel was of the family of Davil." Anma the prophetess, the diunghter of Phamuel, conld trace her deseent from the tribe of Asher (Luke ii. 3); Paul asserted that he belonged to the tribe of Benjamin (Lom. xi. 1; Acts xiii. 21); and the grandsons of Jude, the brother of our Lord, had to appear before Domitian, because they were the descendants of David. ${ }^{3}$ Of all the register's, we may be eertain that the royal register of David, from whom the Messiah was to proceed, would be kept with the most serupulous care. These public registers would be destroyed at the destruction of Jerusalem.

From the amotations found interspersed in the genealogieal list given by Matthew, as well as from its omissions, we think it not improbable that he constructed his own genealogy without having recourse to the publie registers. On the other hand, Luke has none of these notes and omissions, so that it is not improbable that he extracted his genealogy from the publie registers, being the genealogieal table of Heli, the father of Mary, and incorporated it into his narrative with the explanatory elause, "being the son, as was supposed, of .Joseph."

1 Vitu, 1 ; Contru Apron. i. 7.

2 Ligrlatfont's Worlss, vol. iii. 1. 41, Pitman's edition.

"Lusebius, Ilist. Evel. iii. 19. 


\section{ISSERT A T I O N II.}

\section{THE CENSUS OF QUIRINIUS.}

LUkE ii. 1, 2.

Literature.-The literature on this subject is extensive, as it is discussed in all commentaries on Luke's Gospel. We give a list of the most important works arranged alphabetically: Andrews, Life of Christ, pp. $1 \mathrm{ff}$; Bleek's Synoptisehe EnFlarung, vol. i. pp. $66 \mathrm{ff}$. ; Caspari's Introduction to the Life of Christ, trans. pp. 34-38; Davidson's Introduction to the Study of the New Testament, 3rd ed. vol. i. lp. 451-456; Ebrard's Gospel History, pp. 136 ff. ; Ewald's Gesehichte des Volkes Israel, vol. v. pp. 132 ff. ; trans. vol. vi. pp. 152-157; Farrar's Life of Christ, vol. ii. Appendix; Date of Christ's Birth, pp. 149-152; Gerlach, Die römischen Statthalter in Syria und Judeca, pp. 22-42 ; Godet's Commentary on Luke's Gospel, trans. vol. i. pp. 119-128; Greswell's Dissertations on the Gospels, vol. i. Dissertation xii. pp. 443-525; Huschke, Ueber den au der Geburt Jesu Christi gehalten Census, a work which has not been accessible to me; Lewin's Fasti Sacri; Meyer's Commentary on Luke; Mommsen's Provinees of the Roman Empire; Schürer, The Jewish People in the Time of Christ; Sieffert's article, "Schatzung," in Herzog's Real-Eneyclopaidie, 2nd ed.; Smith's Dietionary of the Bible, article, "Cyrenius"; Steinmeyer, Die Gesehiehte der Geburt des Jesus; Wieseler's Chronologisehe Synopse, pp. $73 \mathrm{ff}$; trans. by the Rev. P. Venables, pp. 45-135; Winer's Realwörterbuch, articles, "Quirinus" and "Schatzung"; and Zumpt, Das Geburtsjahr Christi.

The statement of Luke concerning the census of Quirinius, 


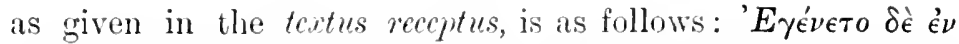

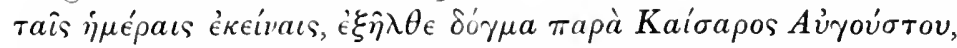

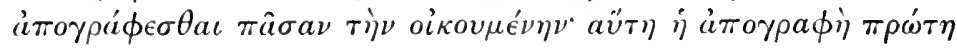

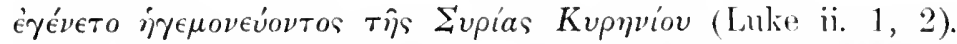
These worls are translaterl ancording to the Authorised Version: "And it came to pass in those diass, that there went out a decree from Ciesal Alugustus that all the world shomld be taxed. (And this taxing was first made when Cyrenius was governor of Syria"); and, according to the lievised Version: "Now it came to pass in those days, there went ont a decree from Ciesalr Augustus, that all the world should be enrolled. This was the first enolment made when Quirinius was governor of Syria." This deeree of

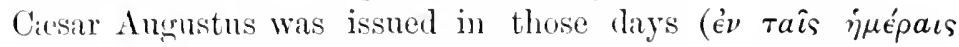
ékeinas), that is, at or about the time of our Lord's birth.

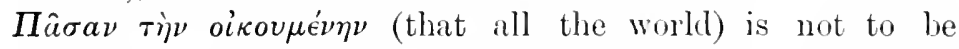
restricted to the land of Judiea or Palestine (Kuinoel, Olshausen), but denotes the Roman Empire; for such is the usual import of the expression, and is evidently its meaning here, as the deeree was issued by Ciusar Augustus. 'A Authorised Version, but "to be emrollerl," as in the Revised Version. A census was to be male, mobably to ascertain the population and resources of the empire, and, perhaps, with a view to future taxation; but it loes not necessarily infer that such a taxation should follow immediately. So, also, aimorpaфí does not denote taxation, but emrolnent. The article $\dot{\eta}$ before imorpapi is omitted in om best manuscripts, \& B D, and is rejeeted hy Lachmam, Tischendorf, and Westeott and Hort, lut retained hy Alford and Meyer. The lievisers have omitted it without any marginal note. Its onisision causes a slight change in the translation.

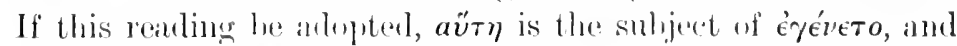

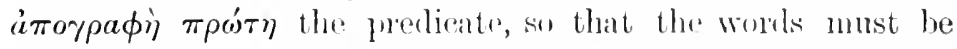
rendered as in the lievised Version: "This was the first

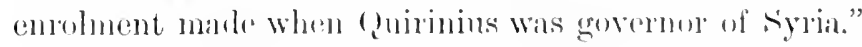

The reality of this census of the limmin linp pire has been questionerlon the erromel that there is mo historieal evidence, cither from Josephus or from the lioman historians, that 
such a census was taken at this period. But this is a mistake. Various statistical accounts were drawn up. Julius Ciesar, we are informed, had undertaken, with a view to an exact system of taxation, a great statistical work, containing a survey of the Roman Empire (descriptio ortis). This work was continued by Augustus, and is said to have occupied thirty-two years. Augustus, with that wisdom for which he was so distinguished, sought to consolidate his vast empire, and for this purpose several censuses were taken during his reign. Of these three are specially mentioned. Thus Suetonius says: "Augustus thrice took a census of the people, the first and the third time with a colleague, and the second by himself." 1 This statement is confirmed by the Ancyran monument, ${ }^{2}$ containing a record of the actions of Augustus. On it we are informed that these three censuses were held U.c. 726,746 , and 767 , corresponding with B.C. 28,8 , and A.D. $13 .^{3}$ It may be that no special census is mentioned about the year of our Lord's birth, yet there is nothing against the supposition that such a census may then have been made, or that one of the censuses above mentioned may then have been carried into effect. Indeed, the second of these, which occurred in B.c. 8, according to many biblical scholars, was made in the very year in which our Lord was born. It has, indeed, been affirmed that these censuses were made only of Roman citizens; but we learn from Tacitus that they included also the allies and dependencies of Rome. We are informed by him that after the death of Augustus, Tiberius ordered the imperial register to

1 snetonius, Augustus, xxvii.

2 The Monumentum Ancyranum is an inscription in Greek and Latin on the walls of a temple erected in honour of Augustus at Ancyra the modern Angora. It contains an account of the principal events in the life of that emperor; a great part of the inscription is still legible.

s Much complication arises from the different methods of chronology ; the one dated from the founding of Rome A.J.c., and the other our ordinarily received Christian era. The Roman era corresponding with the Christian era was A.U.c. 754. The conversion of a clate B.C. or A.D into a date A.U.c. is therefore effected by subtracting the date B.c. and by adding the date A.D. to the number 754 . Thns the date of the death of Herod the Great is A.U.C. 750, that is, B.c. 4. 
be produced and read. It contained a summary of the resources of the State, the number of Romans and anxiliaries in the armies, the extent of the navy, kingdoms, provinces, tributes, custons, the public expenditure and largesses. The register wats all written by the haml of Aurnustus. ${ }^{1}$

It has been further ohjected that in a general census of the Lioman Empire, the kingrom of .Judiea would be exclucled, because at this time it formed no part of the empire, but was governed by a king of its own, and it was not until it had lost its independence by the dethronement of Archclaus, the son and successor of Herol the (ireat, that a census of the population with a view to taxation was made. But there is no reason to suppose that these eonfederate kingloms were excluded from the census which was taken of the Roman Empire. The reges socii of the Romans were merely nominal rulers: they not only owned the suzerainty of Rome, but they were appointed and dethroned at the pleasure of the Roman senate and the emperor: there was no great difference between their power and that of the Roman proconsuls. The independence of Judiea was at this time only nominal: the Jews had to take an oath of allegiance to Augustus as well as to their own kingr. ${ }^{2}$ Herod conld do nothing without the permission of Caesar. These subordinate lings certainly taxed their own people: and in this instance the enrolnent mentioned in Luke's (iospel, although enjoined by the emperor, was carried ont, not aceorling to Roman, but aceorling to Jewish procedure; besides, it must be remembered that it was not an assessment, but merely a census.

The exalet year of our Lord's birth is still a matter of doubt, and diflerent dates have heen assigned to it. Our received chromology is not older than the sixth century, and was first introlueed into the Christim Church by Ibionysius, surnamer lixigums, a monk who lived in the reign of Justinian, and hence it is called the Dimysian era. It is now ackunwledged by almost all erities and chromologists to be erroneous; and it is consinlered that the date of our Lord's birth was several years earlier than is represented in our common ehronology. There is no doubt whatever that

1 'l'icitus, $A$ n. i. 11. ¿Juse]hus, Ant. xvii. 2. 4. 
Herod the Great was alive when our Lord was born. This is affirmed both by Matthew and Luke. Aceording to Matthew, Jesus was born in Bethlehem of Judiea in the days of Herod the king (Matt. ii. 1); and, aecording to Luke, it was in the days of Herod the king of Judra (Luke i. 5) that the angel of the Lord appeared to Zacharias, the father of the Baptist. Now the date of Herod's death ean be aseertained from the history of Josephus with great exactness. "Herod," he says, " died the fifth day after he had eaused Antipater (his son) to be slain, having reigned, sinee he had procured Antigonus to be slain, thirty-four years; and since he had been deelared king by the Romans, thirty-seven years." ${ }^{1}$ Almost all ehronologists have fixed upon B.C. 4 , or A.U.c. 750 , as the date of Herod's death. ${ }^{2}$ There is also evidence that our Lord was born some time before that event, because time must be allowed for the presentation in the temple, the visit of the wise men, and the flight into Egypt; and yet it is evident that no great amount of time eould have elapsed (Matt. ii. 19), perhaps one or two years. Eusebius says that it was in the forty-seeond year of the reign of Augustus, and the twenty-eighth year after the subjugation of Egypt and the death of Antony and Cleopatra, that our Lord was born in Bethlehem of Judrea: ${ }^{3}$ giving the approximate date of B.C. 3 . The following are the opinions of some of the leading critics and ehronologists: Zumpt fixes on B.c. 8; Alford and Ebrard, on B.c. 7; Kepler and Lardner, on B.c. 6 ; Usher, on B.c. 5 ; Bengel, Wieseler, Greswell, and Ellicott, on B.C. 4. Probably the most eorreet date is B.c. 5, a year before the death of Herod.

The enrolment is said to have been made when Quirinius was governor of Syria. Publius Sulpieius Quirinius, or as his name is elsewhere written, Quirinus, ${ }^{4}$ was a distinguished Roman officer. He was entrusted with many important com-

1 Joseph. Ant. xvii. 8. 1.

2 So Weiseler, Winer, Meyer, Schiirer, Zumpt.

${ }^{3}$ Eusebius, Hist. Eccl. i. 5.

${ }^{4}$ In Tacitus and Suetonins the name is written Quirinus; in Strabo and Josephus, Quirinius. Quirinins is the Greek form of the Roman name. In the Vatican manuscript it is Quireinus (Kvpsivov); in the Alexandrian, Quirunius (Knovyiov); and in the Sinaitic, Quirenius (Kupnviou). 
missions, and was in great favour both with Augustus and with 'Tiberins. He was consul, B.c. 12, along with Valerius Messala Barbatus. Our information eoncerning him is chiefly derived from the account given by Tucitus. "Alout this time Tiberius desired of the senate that the decease of Sulpicius Quirinus might be celebrated by a publie funeral. Quirinus was born at Lanuvium, a numicipal town, and nowise related to the ancient patrician family of the Sulpicii; but being a brave soldier was for his active services rewarded with the consulship under Angustus, and soon after with a trimmph for ariving the Homonadensians ont of their strongholds in Cilicia. When the young Cains Casar (the grandson of Augustus) was sent to settle the affairs of Armenia, Quirinus was appointed his tutor, and at the same time paid court to Tiberins, then in his retirement at Rhorles. The emperor represented this to the senate; he extolled the kind offices of Quirinus, and branded Mareus Lollins as the anthor of the perverse behaviour of Cains Casar to himself, and of all the jarring between them. But the menory of Quirims was not agreealle to the rest of the senate by reason of the danger to which he exposed Lepida, ${ }^{1}$ as I have before related, and his sordid meammess and overbearing eonduct in the latter piart of his life." 2

But in formidalile objection to the statement regarding the census occurs, amounting to an apparent contralietion. Aceorling to Lnke, Quirinins was governor of Syria, and the census or enrolnent was mate by him at or about the time of our Lord's birth (Luke ii. 1). But Josephus informs us that Quirinius did not reeeive the anpointment of governor of Syria until ten years after, when Archelius, the son of Herod, was deposed, and Judata was annexed to the cminge and incorporated with the provinee of Syria. Quirinius was then sent into Syria to settle the annexation of Julian, and to take a census of the population with a view to taxation; which census gave rise to that memorable outhreak of the dews heated by Juclas of Cialilee. "Arehelaus" comntry," says

'For the conduct of Quirinius towaml his wifo Lepida, see Tacitns, A $u n$, iii. 22.

${ }^{2}$ 'Tacitus, $A m$. iii. 4 s. 
Josephus, "was ammexed to the province of Syria; and Quirinius, who had been consul, was sent by Cesar to take account of the effects of the reople." 1 And again : Quirinius came himself into Judiea, which was now added to the province of syria, to take an account of their substance and to clispose of the money of Archelaus." ${ }^{2}$ Besides, according to Josephus, it was not Quirinius who was governor of Syria at the time of the death of Herod the Great, which oceurred shortly after the birth of Christ, but Varus, afterwards notorious in Roman history for his defeat and the destruction of his legions by the Germans. He informs us that Varus, the governor of Syria, came to Jerusalem, and presided at the trial of Antipater, the son of Herod, who was put to death by his father five days before his own death. ${ }^{3}$ Varus continued for some time longer, for he quelled the disturbances which arose after the death of Herod.

There is thus an apparent discrepancy in these accounts. Luke states that Quirimins was governor of Syria about the time of our Lord's birth; and Josephus, that this was not until ten years later, and that it was then that he made the census. Some suppose that Luke has committed an error in stating that the census of Quirimins occurred tell years before it actually happened. But it is very improbable that such a mistake shonld be committed by a historian whose extreme accuracy has, in other points, been testified to and verified. Luke was well acquainted with the census of Quirinius which gave rise to the revolt of Judas of Galilee, and alludes to it in his Acts of the Apostles: "After this man rose up Judas of Galilee in the days of the enrolment, and drew away some of the people after him" (Acts v. 37).

When we turn to the statements of the Fathers we have apparently two different accounts. Justin Martyr agrees with Luke that the census was made by Quirinius about the time of our Lord's birth. He makes three allusions to it. In his first Apology he says: "There is a village in the land of the Jews five and thirty stadia from Jerusalem, in which Jesus Christ was born, as you can ascertain from the registers of 1 Josephus, Ant. xvii. 13. 5.

2 Ibid. xviii. 1. 1.

3 Ibid. xvii. 5. 2. 
the enrolment under Quirinius, the first procurator in Judaa." "Christ was born one hundred and lifty years ago under Quirinius." And in his Dialogue with T'rypho he says: "On the occasion of the first census which was taken in Judæa under Quirinius, Joseph went from Nizareth, where he lived, to Bethlehem, to which he belonged, to he enrolled." I Justin here corroborates the statement of Luke, that the census was made under Quirinius; and for the truth of this he appeals to the public registers. The same statement is made by Eusebius: "Christ was born the same year when the first census was taken, and Quirinius was governor of Syria." ?

Tertullian, on the other hand, affirms that when the census mentioned in Luke's Gospel was taken, Sentius Saturninus was governor of Syria. "It is certain," he observes, "that at this very time (when our Lord was born) a census had been taken in Judat by Sentius Saturninus, which might have satisfied their inquiry respecting the family and descent of Christ." 3 Caius Sentius Saturninus filled the office of governor of Syria, B.c. 10-6, and was succeeded by Quintilius Varus, B.c. 6-4. It is too hastily supposed that Tertullian here commits a historical blunder. Many erities affirm that our Lord was born when Satminimus was governor of Syria. This, however, is not asserted by Tertullian: he mercly affirms that under the government of Satminims a census was taken in Judiea ; and there is nothing improbable in the supposition that such a census was appointed or commenced during the last year of the proconsulship of Satuminus, B.c. 6, and was continued and completed by his successor Varus, perhaps with the assistance of Quirinins.

Still the difficulty confronts us that whilst, accorling to Luke, the census was taken at the birth of Christ, when Quirinius was governor of Syria; accorling to Josephus it was not made until ten years later, when at that time Quirinius was appointed governor. Several attempts have been made to solve the difficulty, either hy giving different interpretations to the words of the cringerelist, or by an

'Justin Martyr, Apol. i. ch. xxxiv. and ch. xlvi.; Hial. c. Tryph. ch. Ixxivii.

2 Eusebius, Hist. kiccl. i. 5.

${ }^{3}$ Adv. Murcion. iv. 19. 
examination into the historical circumstances of the times.

Some attempt the solution of the difficulty by conjectural readings and emendations. Beza, Olshausen, and Kuinoel call in question the integrity of the text. They suppose it to be a gloss by some ignorant transcriber; perhaps a marginal note which found its way into the text. Others have recourse to conjectures; for example, that instead of Kvpqviov the original reading was $K \nu \nu \tau \iota \lambda i ́ o v$, referring to Quintilius Varus,

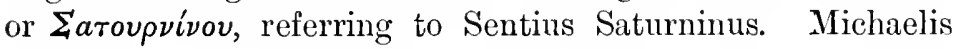

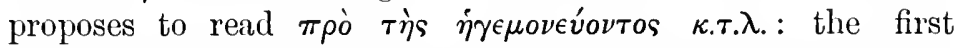
enrolment which took place before Quirinius was governor of Syria. All these and similar suppositions must be rejected as at variance with critical authorities.

Some critics, putting stress on aṽ $\eta$, suppose that the parenthetic clause, "and this taxing was first made when Cyrenius was governor of Syria," 1 was added for the purpose of drawing a distinction between this enrolment and the census made ten years afterwards by Quirinius: this enrolment was the prehude of that more celebrated enrolment made by Quirinius when actual taxation took place. This view of the matter was suggested by Ebrard. "When," he observes, "Luke speaks of a census which was taken at the time of Christ's birth, he must have made a distinction between this and the later census of Quirinius,

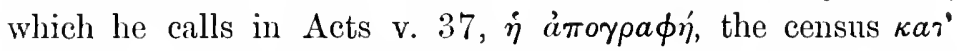
$\epsilon \xi \xi \chi \eta \dot{\nu . "}{ }^{2}$ Calvin appears to have adopted a similar view : "The words of Luke," he observes, " bear this sense, that about the time of our Lord's birth an edict came out to have the people registered, but that the registration could not take place till after a change of the kingdom, when Judæa had been annexed to another province. This clause is accordingly added by way of correction: This first registration was made when Quirinius was governor of Syria; that is, it was then first carried into effect." ${ }^{3}$ But such a view necessitates a different mean-

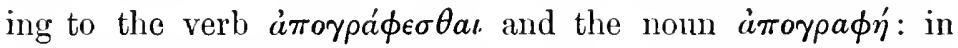
the one case the word signifies to be enrolled; in the other, actual taxation. Besides, according to Luke, the decree was
${ }^{1}$ Authorised Version.
2 Elrard's Gospel History, p. 141.
${ }^{3}$ Calvin on Luke ii. 2. 
not only issued, but actually carried into effect, as is evident from the journey of Joseph and Mary from Nazareth to Bethlehem in order that their names might he registered in the public census.

Other critics, futting stress an the word $\pi \rho \omega$ try, "the first enrolnent," suppose that it stames for the comparative

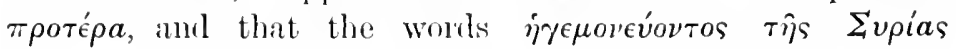
Kupquiov are dependent mpon it, heing governed by it in the genitive. They translate the passage: "This eurolment was made hefore Quirinius was governor of Syria." Thus the enrolment in the text is distinguished from that subsequently mate by Quirinins. This view has been adopted by Tholnck, Ewalk, Wieseler, ${ }^{1}$ Greswell, ${ }^{2}$ and Dr. Samuel Davidson ${ }^{3}$ in his first Introduction to the New Testament. In support of this view it is affirmed that the superlative $\pi \rho \hat{\omega} \tau o s$ is frequently

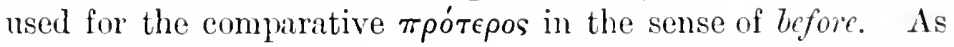
when the Baptist says: "This is He of whom I said, He that eometh after me is become hefore me: for He was before

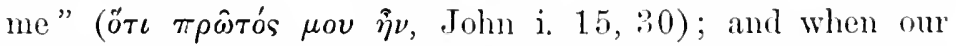
Lord says: "If the word hateth you, ye know that it hath hated Me before it hated you" ( $\pi \rho \hat{\omega} \tau o \nu$ i $\mu \hat{\omega} \nu$, John xv. 1S). Inut such an interpretation is here hardly arlmissible. It not only assumes that the superlative $\pi \rho \omega \tau \eta$, first, is used in the sense of the comparative $\pi \rho \tau^{\prime}$ épa, before; but it causes it to

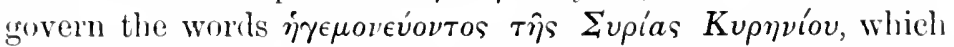
are naturally to be taken as a genitive alsohute. This has been regarded as inadmissible by all our distinguished grammarians. Thus Winer says: "If such were Luke's meaning, his language would he not only ambignous, but also awkward if not ungrammatical. Husehke has not succeded in finding an example which is really parallel: he merely illustrates the very faniliar construction of $\pi \rho \hat{\omega} \tau$ os with the renitive of a nol11." 4

Other erities fix on the word éyéueto, and give it the

1 Wieseler, simnopsis of the Gospels, lill. $101 \mathrm{It}$.

2 (ireswell's lissotation, vel. ii. 1. 523.

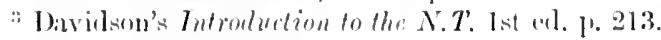

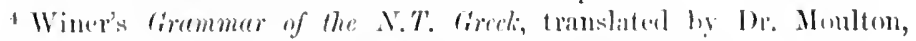
1. 306. So also Buttmann's Grommer of N.T. Cirech, 1. 84. 
sense of was done or eompleted: "This enrolment was completed, as the first enrolment, when Quirinius was governor of Syria." According to this view the evangelist distinguishes between the enrolment begun at the birth of Christ and the enrolment completed under Quirinins. This opinion has been adopted by Hofmam and Canon Cook. ${ }^{1}$ This supposes that no less than ten years elapsed between the issuing of the decree and its completion, which is altogether at variance with the rapid procedure of the Romans. Others distinguish between the enrolment or placing on the register and the levying of the taxation which took place under Quirinius, an opinion to which we have previously alluded.

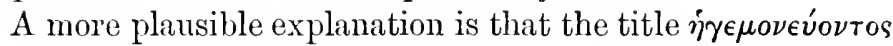
$\tau \hat{\eta} s$ ¿upias was here conferred on Quirinius because he was at this time entrusted with an extraordinary commission in Syria. Quirinius, as we know, was then in the East as an officer of high distinction, and invested with powers. $\mathrm{He}$ defeated the Homonadensians, a Cilician tribe, and shortly afterwards was appointed tutor or governor to Caius Cæesar, the grandson of Augustus, probably about A.D. 1. It has been supposed, not without some grounds, that, in consequence of his distinguished rank and abilities, he was employed as chief commissioner of Syria to carry into effect the census appointed by Augustus, and was for this purpose invested with an authority equal to that of the governor of Syria, who was then either Sentius Saturninus or Quintilius Varus. He might even for this purpose have been appointed joint governor. ${ }^{2}$ This opinion has been adopted by Grotius, Beza, Hug, Winer, Neander, and Gerlach. The great objection to it arises from the silence of history; but as, according to the view here taken, the appointment was only temporary for a definite purpose, its historical omission may easily

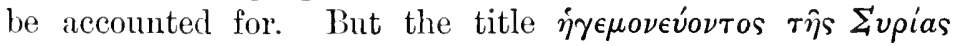

${ }^{1}$ Speaker's Bible, N.T. vol. i. Pl. 326-329, note: On the Census of Cyrenins.

${ }^{2}$ It is very doubtful if there were ever joint governors of Syria. Josephus indeed speaks of Saturninus and Volumnius as governors of Syria, Ant. xvi. 9. 1. But Volumnius, of whom elsewhere we know nothing, may have acted only as legate to Saturninus. 
can only denote "the governor of Syria": if merely an extraordinary eommissioner, a different title would have been employed.

Another possible solution is that Quirinims is here called governor of Syria, because this was the name by which he wits best known when Luke wrote his Gospel; although at the time when he made this early census, at the birth of our Lord, he was not aetually governor. When a man has oeeupied with distinetion an important oflice, he is often spoken of by the title conferred on him in mentioning events which hiappened even prior to his ocerpation of that oflice. Thus Cato Major is known in Roman history as Cato the censor; so Quirinins may have been known as Quirinins the governor of Syria. But there is no gromul for this opinion, especially as the words are quite elear, Quirinius being governor of Syria: ${ }^{1}$ it is adopted by few, and need not oecupy our attention.

Hitherto the solutions of the difficulty have heen drawn chiefly from the text, and are derived from the different

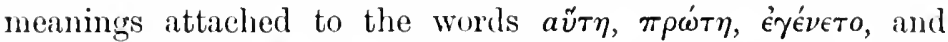

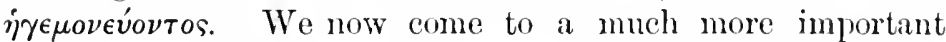
solution of a different character, resting on different grounds, and founded on an exact examination of the historical cireumstances of the times. A. W. Zumpt, nephew of the celebrated grammarian of the same name, in a monograph of great learning and researeh," has undertaken to prove that Quirinius was twice governor of Syria-first, close upon the period usually assigned by biblieal erities for the birth of our Lord, r.c. 5 or 4 ; and a seeond time, ten years afterwards, when Judar was annexed to the province of Syria, as mentioned by Josephus. His reasoning is most ingenious, and is considered to be anvincing by many distingnished crities and historians.

Zumpt makes a very careful inquiry into the snecession of the governors of Syria and the churation of their governments; and he nukes the rliseovery that there is an interval elose upon the time of our Lord's birth which is not accounted for. Aloont 13.C. 10 (Himysian-ert, H.G-14), Titins was

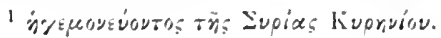
" Jas Cieburtijakr Christi. 
appointed governor of Syria: he was succeeded by Sentius Saturninus, who held the office for three years, B.c. 9-6. His sucessor-Quinctilius Varus-was appointed B.c. 6, and was governor of Syria B.c. 4, the year in which Herod the Great died. After him there is a gap, and no further mention of the governors of Syria is made nutil we come to Quirinius, A.D. 6 (Dionysian era, A.D. 10), except that Volusius Saturninus is mentioned as governor of Syria on a coin of Antioch about A.D. 4. The question then is, Can we determine who was governor of Syria from P.C. 4, when Varus leparted, to A.D. 4, when Volusius Saturninus was appointed? Zumpt, as the result of several most ingenious investigations, arrives at the conclusion that this was Quirinius.

The arguments which he uses in support of this conclusion, if not absolutely convincing, are at least so highly plausible, that they have obtained the assent of our most distinguished Roman historians. Tacitus, in his Annals, informs us that Quirinius, shortly after his consulship, obtained a triumph for his victory over the Homonadensians, having driven them out of their strongholds in Cilicia. ${ }^{2}$ This war is also mentioned by Strabo. "Quirinius," he says, "reduced them (the Homonadensians) by famine, and took four thousand prisoners, whom he settled as inhabitants in the neighbouring eities." ${ }^{3}$ It occurred at the very time in question (B.C. 4 to A.D. 1), for Tacitus informs us that it was before Quirinius was appointed tutor or governor to Cains Cresar (A.D. 1). The question arises, In what capacity did

1 The governors of Syria are thus given by Zumpt-

M. Titius, ahout B.c. 10.

C. Sentius Satmminus, B.c. 9-6.

P. Quinctilius Varus, B.c. 6-4.

P. Sulpicins Quirinius, B.c. 4-1 ?.

M. Lollius, B.C. 1 to A.D. 2.

C. Marcins Censorinus, A.D. 2-4.

L. Volusius Saturninus, A.D. 4-6.

P. Sulpicius Quirinius, A.D. 6-11.

Zumpt's Das Geburtsjahr Christi, p. 71. See also Schiirer's The Jewish People in the Time of Jesus Christ, Div. i. vol. i. pl]. 351-357.

2 Tacitus, Ann. iii. 48 : "Consulatum sub divo Augusto, mox expugnatis per Ciliciam Homonadensium castellis insignia triumphi adeptus."

3 Strabo, xii. 6.5. 
Quirinius carry on this war? It must have been as governor of that province to which the Homomarlensians belonged, and that province must have heen a proconsular provinee; for it was only the governor of a juconsular province who could possess an army and make war, and to whom the peace of the province he governed was entrusted. Now, Zumpt proves hy an exhanstive process that this province could not have been Aslia, Bithynia, Iontus, Pamphylia, Cappadocia, or Galatia, which were pretorian or senatorial provinces, and possessed no army; but must have been Cilicia, especially as the Homonadensians had their strongholds within that country. lint at this time the province of Cilicia was reduced in size, and its eastern half was assigned to Syria. It appears to have had no governor of its own; so that the conclusion at which Zumpt arrives is that Quiminis, at the time of that war with the Homonadensians, was governor of Syria. This conclusion has been adopted lyy the distinguished Roman historian Mommsen: "The Syrian army," he says, "carried out the chastisement of the Homonadensians; the governor, l'ublius Suppicius Quirinius, advanced some years later into their territory, eut ofl their supplies, and compelled them to submit cn masse, whereupon they were distributed among the surromding townships, and their former territory was laid waste." 1

This view is supposed to be supported by the fragment of a sepulchral inscription found at Tibur (Tivoli) ${ }^{2}$ in 1764 , and now placed in the Vatican Musemm. The inseription states that the person whom it eommemorates was proconsul of Asia and twiee governor of Syria and Phonicia. Althongh the nane Quirinius does not appear on it, yet it is supposed that it refers to his official appointments, supposing that he was twice governor of Syrtia. Of eourse such an opinion is liable to great uncertainty, lut it has been adopited by such distingnished historians as Mommsen ${ }^{3}$ and Merivale. The

1 Mommsen, The Promines of the Romun Empire, vol. i. p. 336, trans-

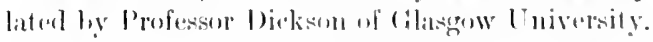

"Cinon Cook, in the sipuler's Commentury, is mistaken in supposing that this inscription was fommel in the 'Tiber.

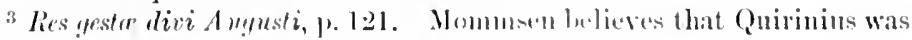

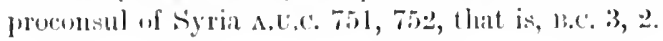


inscription, indeed, proves that the person referred to was twice governor of Syria, but there is no proof that Quirinins was ever proconsul of Asia. As Schiirer observes: "The theory that Quirinius was twice governor of Syria is not to he based on the inscription ; bnt, on the contrary, the application of the inseription to Quirinins is based upon the pronf, elsewhere obtained, that he held the governorship a second time." 1

From these investigations of Zumpt, and the discovery made by him that Quirinius was twice governor of Syria, the first time shortly after the birth of Christ, and the second time ten years later, the following result may be said to have been obtained. Our Lord was born about B.c. 5, when Varus was governor of Syria. ${ }^{2}$ The census of the empire, ordered by a decree of Augustus, was, according to the statement of Tertullian, commenced by Saturnimus, B.c. 6, or, perhaps, rather a year later by Varus, B.c. 5, and completer by Quirinius, who entered upon his first government B.c. 4. Quirinius was not appointed governor until after the death of Herod, and consequently after the birth of Christ; but the census was called after him, because he carried it into effect. Ten years after this he was a second time appointed governor of Syria, and made a second census with a view to taxation. This gives a satisfactory interpretation to the whole passage: the two censuses are distinguished. Luke says: "This was the first enrolment, when Quirinius was governor of Syria," implying that there was a second enrolment by Quirinius, which occurred ten years later, during his second government. This view of Zumpt has been accepted by the two great Roman historians, Mommsen and Merivale. "A remarkable light," olsserves Merivale, "has recently been thrown upon this point - the year of our Lord's birth-by the demonstration, as it seems to be, of Augustus Zumpt, that Quirinius was first governor of Syria from B.c. 4 to B.c. 1. Accordingly, the enumeration begun or appointed under his predecessor Varus, and before the death of Herod, was completed after that event

I Schürer, History of the People of Israel, vol. i. p. 354.

2 Zumpt fixes on B.c. 8, when Saturninus was governor of Syria ; but this appears to be too early. 
by (Quirinius. It would appear from hence that our Lord's birth was A.U.C. 750 , or 749 at the earliest," 1 that is, B.C. 4 or 5 .

'Merivale's History of the Romans under the Empire, vol. iv. I. 428, note. 


\section{LIST OF WORKS CONSULIED OR REFERRED TO.}

Аввотт's, Dr. Edwin, Article on the Gospels in the Encyclopedia Britannica. Fourth Edition. Vol. $x$.

Abbott and Rushbrooke's Common Tradition of the Synoptic Gospels. London, 1884.

Alford's Greek Testament. Vol. i. Fourth Edition. London, 1889. Last Edition, 1894.

Andrews' Life of our Lord. London, 1869. New and

Enlarged Edition. Edinburgh (T. \& T. Clark), 1892.

Ante-Nicene Library. Edinburgh, 1867-1872.

Badham's Formation of the Four Gospels. London, 1892.

Baring-Gould, Lost and Hostile Gospels. London, 1874.

Barnes' Canonical and Uncanonical Gospels. London, 1891.

Baur's Marcus-Evangelimm. Tuibingen, 1851.

Bengelii Gnomon Novi Testamenti. Editio tertia. Tübingen,

1850. Translated by Fletcher. Edinburgh, 1859.

Bleek's Einleitung in das neue Testament. Translated by

Urwick. Edinburgh, 1869.

Bleek's Synoptische Erklärung der drei ersten Evangelien. Leipzig, 1862.

Bruce's Kingdom of God. Edinburgh, 1889.

Bryennios' Teaching of the Twelve Apostles. Translated by

Hitchcock and Brown. New York, 1884.

Burgon on the Last Twelve Verses in St. Mark's Gospel. Oxford, 1871.

Calvin's Commentaries: The Gospels. Calvin Translation

Society.

Campbell, Principal, On the Gospels. Edinburgh, 1821. 
Campluell, Dr. Colin, Critical Studies in St. Luke. Edinburgh, 1891.

Carpenter, The Finst Three Gospels. Seeond Edition. London, 1890.

Carr on Mattlew. Cambrilge Bible for Schools. Cambridge, 1890 .

Caspari's Life of Christ. Translation. Elinburgh ('T. \& T. (litrk), 1876.

Cave's Lives of the Apostles. Oxford, 1840.

Charteris' Canonicity. Elinburgh, 1880.

Credner's Einleitung in das nene Testament. Halle, $18: 36$.

Davidson's Biblical Critieism: New Testament. Edinburgh, 1852.

Davidson's Introduction to the New Testament. First

Edition. London, 1849.

Davidson's Introduction to the Study of the New 'Testament.

London, 1868 . Third Edition, 1894.

De Wette's Einleitung in das N. T. Sechste Ausgrabe. Berlin, 1860.

Inols' Introduction to the New Testament. London, 1868. Ebrard, The diospel History. Translation. Edinburgh, 1869. Edershein's Life and Times of Jesus. London, 1886.

Eichhor'n's Einleitung in das N. T. Leiprzig, 1804.

Ellicott's Ilistorieal Lectures on the Life of our Lord.

Hulsein Leetures. Third Edition. London, 1862.

Eneyelopelia Isritamniea. Ninth Edition.

Essalys and Reviews: Jowett's lissaly. Wighth Edition. London, 1881.

Euschii IIstorie Eeclesiasticie. Edited by Hemiehen. Leiprig, 1827 .

Ewald's, IIeinrich, (iesehichte des Volkes Isracl. Dritte Ansgabe. Giottingen, 1864. Tramslation. London, $1876-1886$.

Ewall's, P'anl, Hamptproblan der Evangelienfrange. Leipzig, 1890.

Expositor. Varions drticles.

Firrar on Luke. Cambridge bible for the Sehools. Cambriclge, 1882.

l'arrar's bitrly doilys of C'hristianity. London, 1852. 
Farrar's Life of Christ. Thirteenth Edition. London.

Farrar's Messages of the Books. London, 1884.

Geikic's Life of Christ. Eleventh edition. London, 1879.

Godet's Studies on the New Testament. Edited by the Rev.

W. H. Lyttelton. Eighth Edition. London, 1888.

Godet's Commentary on St. Luke. Translation. Edinburgh, 1875 .

Greswell's Dissertations. Oxford, 1830.

Greswell's Harmonia Evangelica. Third Exlition. Oxford, 1840 .

('riesbach's Greek Testament. Second Edition. London, 1818.

Guericke's Nentestamentliche Isagogik. Dritte Auflage. Leipzig, 1868.

Harris, The newly-recovered Gospel of St. Peter. London, 1894 .

Harris on the Diatessaron of Tatian. London, 1890.

Hase's Life of Jesus. Translation. Boston, 1860.

Hemphill, Rev. S., The Diatessaron of Tatian. London, 1888.

Hervey, Lord A., The Genealogies of our Lord. Cambridge, $185:$.

Herzog's Real-Encyklopiillie. Zweite Auflage.

Hilgenfeld's Einleitung in das neue T'estament. Jena, 1875.

Holtzmann's Einleitung in das neue Testament. Freiburg, 1885.

Holtzmamn's Die synoptischen Evangelien. Leipzig, 1863. Holtzmann's Kommentar zun N. T. Die Synoptiker. Freiburg, 1889.

Horne's Introduction to the Scriptures. Tenth Edition.

London, 1857. Fourteenth Edition edited by $\mathrm{D}_{1}$ : Tregelles and Rev. John Ayre. London, 1877.

Hug's Introduction to the N. T. Translation. London, 1827. Jolley, The Synoptic Problem. London, 1893.

Jones on the Canon. Oxford Edition, 1827.

Jusephns, Works of. Translation by Whiston.

Keim's Jesus of Nazara. Translation. London, 1876-1883.

Kerr's Introduction to the New Testament Study. New

York, 1892.

Kirchhofer's Quellensammlung. Zurich, 1842. 
Kitto's Cyclopedia of Biblieal Literature. Third Elition. Edinburghl, 1869.

Kuinoel, Novi Testamenti Libri Historii. London, 1835.

Liehmann's Novum Testamentum Grece. Berlin, 18+2.

Lange's Life of Christ. Translation. Eilinburgh, 1864.

Lardner's Works. Octavo Edition, 178s. Quarto Edition, 1815.

Lechler's Uas apostolisehe Zeitalter. Zweite Auflage. Stuttgart, 1857. 'Translation of the Third Edition. Edinburgh, 1886.

Lewis, Mrs., The Four Gospels. Translated from the Sinaitie Palimpsest. London, 1894.

Lightfoot's (Dr. John) Works. Edited by Pitman. London, 1825 .

Lightfoot's, Bishop, Essays on Supernatural Religion. London, 1889.

Lightfoot's, Bishop, Apostolic Fathers: St. Clement of Rome. London, 1890.

Lightfoot, Bishop, Ignatius and l'olyearp. London, 1885.

Macknight's Harmony of the Gospels. London, 1763.

Maclear on Mark. Cambridge Bible for Schools. Cambridge, 1886 .

Meclellan on the Gospels. London, 1878.

Mangold's Edition of lileck's Einleitung in dits N. T. Vierte Auflage. Berlin, 1886.

Mareion's Gospel. Translated by .J. Hamlyn Hill. Guemsey, 1891.

Meyer's Commentaries on Matthew, Mark, and Luke. Translation. Edinburgh ('T. \& T. Clark), 1877.

Michaelis' Introduction to the New 'Testament. Edited by Marsh. Second Edition. London, 1802.

Morison's Commentary on Matthew. Second Edition. London, 1883.

Morison's Commentary on Mark. Third Eilition. London, 1882.

Neinder's Life of Christ. liohn's Edition.

Neander's Chureh History. Pohn's Edition.

Nicholson, The Gospel according to the flebrews. London, 1879. 
Norton's Genuineness of the Gospels. London, 1847.

Olshausen on the Gospels. Translation. Edinburgh, 1863. Iffleiderer's Philosophy and Development of Religion. Gifford Lectures. Edinburgh, 1894.

I'ulpit Commentary : The Gospels; Matthew, Mark, and Luke. Ramsay's Christianity and the Roman Empire. Second Edition. London, 1893.

Renan's Life of Jesus.

Resch's Agrapha. Leipzig, 1889.

Renss' Geschichte der heiligen Schriften N. T. Vierte Auflage. Braunschwieg, 1866. Translation. London, 1884.

Roberts' Greek, the Language of Christ and His Apostles. London, 1888.

Roediger's Synopsis Evangeliorum. Halle, 1839.

Row's Jesus of the Evangelists. London, 1865.

Row's Bampton Lectures. 1877.

Rushbrooke's Synopticon. London, 1880.

Salmon's Introduction to the N. T. London, 1885. Fourth

Edition, 1889. Seventh Edition, 1894.

Sanday's Articles on the Synoptic Problem in the Expositor. Vol. iv. Fourth Series.

Sanday's Gospels of the Second Century. London, 1876.

Schaff's Encyclopedia of Biblical Theology. Edinburgh, 1883. Schaff's History of the Christian Church: Apostolic

Christianity. Edinburgh, 1887.

Schaff's Oldest Church Manual. 1883.

Schaff's Popular Commentary: The Gospels. Edinburgh, 1879 .

Schleiermacher on Luke's Gospel. Translation by Thirlwall. London, 1825.

Schmid, Biblical Theology of the New Testament. Translation. Edinburgh, 1882.

Schïrer's Jewish People in the Time of Christ. Translation. Edinburgh, 1885, 1886.

Scrivener's Introduction to the Criticism of the N. T. First Edition. Cambridge, 1861. Third Edition, 1883.

Fourth Edition. London, 1894.

Smith's Dictionary of Christian Biography. 
Smith's Dietionary of the Bible. London, 1863. Seeond Edition of the First Volmme, 1893.

Smith of Jordanhill, Dissertations on the Gospels. Edinburgh, 1883.

Speaker's Commentary: The Gospels. 1878.

Stanley's Sermons on the Apostolic Age. Third Edition. London, 1874.

Stroud's Greek Harmony of the Four Gospels. London, 1883.

Swete's Apocryphal Gospel of Peter. Cambridge, 1893.

Tatian's Diatessaron. Translated by J. Hamlyn Hill. Edinburgh, 1894.

Thilo, Codex Apocryphus N. T. Leipzig, 1832.

Tholuck on the Sermon on the Mount. Translation. Edinburgh, 1860.

Tischendorf's Novum Testamentum Græec. Editio Septima.

Tischendorf, Wann wurden unsere Evangelien verfasst?

Tischendorf, Synopsis Evangelica. Leipzig, 1864.

Tregelles' Novum Testamentum Grace. 1857-1879.

Tregelles' Printed Text of the Greek Testament. London, 1854.

Turpie, The Old Testament in the New. London, 1868.

Turpie, The New Testament View of the Old. London, 1872.

Volkmar's Mareus und die Synopse der Evangelien. Ziirich, 1876.

Weiss' Einleitung in das N. T. Berlin, 1886. Translation. Londoll, 1887.

Weiss' Life of Christ. Translation. Edinburgh, 1883.

Weizsiicker's Apostolisches Zeitalter. Freiburg, 1890.

Translation. London, 1894.

Wendt's Lehre Jesu. Göttingen, 1886.

Westeott on the Canon of the N. T. Second Edition. London, 1866.

Westeott's Introduction to the Stuly of the New Testament. Cambrilge, 1860.

Westeott and 11ort, 'The New 'Testament in Greek. Cambrielge, 1881 . 
Wieseler's Chronologische Synopsis d. Evangelien. Hamburg, 1843. Translated by Venables. Cambridge, 1854.

Winer's Biblisches Wörterbuch. Leipzig, 1833.

Winer's Grammar of N. T. Greek. Translated by Moulton. Seeond Edition. Edinburgh, 1877.

Wright's Composition of the Four Gospels. London, 1890.

Zeller's Apostelgesehichte. Stuttgart, 1854. Translation. London, 1875.

Zumpt's Das Geburtsjahr Christi. Leipzig, 1869. 


\section{N D ICES.}

\section{TEXTS IN THE SYNOPTIC GOSPELS ILLLSTIATED OR EXPLAINED.}

\begin{tabular}{|c|c|c|c|c|c|}
\hline & 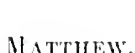 & PAGE & & MARK. & PAGI \\
\hline & & & x. $46-52$ & & 8 \\
\hline i. $1-17$. & . & . $\quad 249 \mathrm{ff}$ & xiv. 52 & . & . 17 \\
\hline i. 8 , & . & . $\quad 255$ & xvi. $9-20$ & & $18 i-20$ \\
\hline $\begin{array}{l}\text { ii. } 1,2 \\
\text { ii. } 15\end{array}$ & · & 130-134 & & L,UKE. & \\
\hline ii. 16 . & . & $\begin{array}{r}151-153 \\
. \quad 135\end{array}$ & i. $1-3$ & . & 22 \\
\hline ii. 17,18 & . & $153-155$ & ii. 1,2 & . & 2701 \\
\hline ii. 23 . & . & $155-158$ & ii. 14 & . & $238-24$ \\
\hline vi. 13 . & . & . $\quad 137$ & iii. $23-38$ & . & . 2491 \\
\hline xx. 29-3.4 & . & . 80,81 & iii. 23 . & . & 26 \\
\hline xxiii. 35. & . & . $\quad 142$ & iii. 36 & . & 25 \\
\hline xxvii. 9, 10 & . & $158-166$ & xi. $2-4$ & . & 241 \\
\hline xxvii, 51-58 & . & . $\quad 102$ & xviii $35-43$ & & . $\quad 80-x-1$ \\
\hline & & & xxii. 43,44 & . & $241-24$ \\
\hline
\end{tabular}

\section{INDEX OF AITHORS AND SUBJECTS}

Ansorg's Article on the Gosprels in Encyclopelia Bitamiea, 59, 197.

$\Lambda$ libott and Rushbrooke, Common 'Tradition of tlue Symoptic (iospels, 46, 59.

Aearlemy, the, Letters on the Sinaitic Syriac MS., 252.

Africanns, Julius, on the Fenealogrios, 261.

Alexander, I)r. Limlsay, ('omuection of the Old amb Now Trotament, 152.

Alfurl, bean, Framentary nature of the (iospels, 9; their independruee of each otluer, 46; inclemendence of Matthew anul Luke, 50 ; the symoptie problem, 50; impessibility of a has. mony of the Synopties, st; on the star of the wise men, 134: on the fiospel of 11 ark, 187; rejection of Mark xivi. 9-20, 18., 196; the uchealouries, 250 . Aneylan monmment, the, 2-7.

Aullews liti of our Loril, $249,265$.

Antiocl, the linthilace of luke, 222 . Aplogies of .lustin, 17.

Apostolie C'unstitutions, yluted, 195.

Alalie version of 'Tatian's Diatessinon, 15.

Aramaie supposed to be the langruage of Christ, 1: 6 . 
Aramaie Gospel, theory of, 60 .

Assemanni, Biblioth. Orient., 15.

A thanasius, Gospel symbols, 10.

Augustiue, Gospel symbols, 10 ; dejendence of Mark on Matthew, 44 ; Matthew wrote in Hebrew, 112.

Augustus, deeree of, $270,271$.

Authentieity, sec Genuineness.

Authors of the Synoptie Gospels, 9.

BAnnan's Formation of the Four Gospels, 37 .

Baeon, Lord, on Propheey, 153.

Baring-Gould, Lives of the Saints, 224 ; Lost and Hostile Gospels, 7, 213, $217,219$.

liarnabas, Epistle of, 94.

barnes' Canonical and Uneanonieal Gospels, 67.

Basilides, referred to, 97 .

lian's theory of the origin of the Gospels, 21.

Bengel's Gnomon, 156, 265.

Berthoklt's Einleitung, 58.

Beysehlagr's Lehen Jesin, 62.

lirk's Horre Evangrelice, 206.

Biscoe on the Acts, 255 .

Bleek's Introduetion to the N.T.: dependence of Mark on Matthew, 44; Mark's Gospel a compilation from Matthew and Luke, 47; on Papias' use of the term $\lambda$ ó $\gamma\llcorner\alpha, 66$; on Matthew's quotations from the O.T., 149 ; on Marcion's Gospel, 220.

Blind Bartimeus restored to sight at Jericho, 80.

Bloody, the, sweat, 241-243.

Brnce's Apologeties, 83; Kingdom of Got, 39.

Burgon's Last twelve verses of Mark, $187 \mathrm{fi}$.

Bryennios' Dirlachè, 91.

C.esar, Julins, his survey of the Roman Enprire, 271.

Ciesarea, the Gospel of Luke supposed to be written from, 215.

Galvin : on Christ being alled a Nazarene, 157; nistake committed in attriluting a prophesy of Zecharial to Jeremiah, 165 ; supposes that the line of Solomon faiked in Alazial, 259 ; on the census of Quirinins, 277 .

Camplell, Prineipal, referrerl to, 201.

Camplell, Dr. Colin, Critical Stuchies in Luke's Gospel, 220.

Candour, necessity of, in interpretation, 75.

Canonical and Apocryphal Gospels, 7 .

Carr on Matthew's Gospel, 101, 263.
Caspari's Life of Christ, 89, 269.

Catechetical schools, 53.

Cave's Life of the Aprostles: St. Matthew, 106 ; St. Luke, 224.

Celsus refers to the genealogies, 211.

Census of the Roman Empire, 270.

Census of Quirinus, 269-284.

Characteristics of Mark's tospel, 185; of Luke's Gospel, 231-233.

Charles, Rev. Mr., on the Simaitic Syriae, 253.

Charteris' Canonieity, 7, 14.

Chronological order in the Synopties, 42,87 .

Ciasea, Agostino, on Tatian's Diatessaron, 15.

Cilicia joined to the provinee of Syria and under the governorship of Quirinins, 282.

Clemens Alexandrinus : number of the Gospels, 7 ; genuineness of the Syuoptic Gospels, 11 ; ristinguishes between Matthew and Levi, 105; on the Gospel according to the Hebrews, 121 ; date of Mark's Gospel, 203.

Clemens Ronranus, testimony to Matthew's Gospel, 93.

Codices B and «, connection between them, 190.

Codex Brixianus, 138, 241.

Codex Bobbiensis, 191, 253.

Codex Regrius Parisiensis or uncial MS., L., 190 .

Contents of Matthew's Gospel, 144 ; of Mark's, 207 ; of Luke's, 247.

Cook, Canon, Revised version of the first three Gospels, 244.

Conybeare, Aristion the author of the last verses of Mark, 199.

Crerlner's Einleitung, 4, 41, 100, 128, $181,230$.

Curetonian Syriac, 21.

Cureton on the Ignatian Epistles, 95.

Cyrenius, governor of Syria, sce Quirinius.

DATE of Matthew's Gospel, 139-144; of Mark's Gospel, 202-206; of Luke's Gospel, 244-247.

Date of our Lork's birtl, 272.

Davidie deseent of Christ, '263-267.

I avidson's Hermenentics, 147, 149, 162.

Davidson's Introduction to the Study of the N.T.; on the want of graphic deseription in Matthew's Gospel, 101; on the repetitions in Matthew's Gospel, 103; number of quotations in Matthew's Gospel, 147 ; linguistic peenliarities in Luke's Gospel, 230.

Design of Matthew's Gospel, 108; of 
Mark's Gospel, 181; of Luke's Gospel, 228.

De Wette's Einleitung, 7, 45, 99, 212.

Diatessirnon of Tatian, 14-16.

Dirlache, references in it to the Gosprel of Matthew, 91-93.

Ditferenees between the Synoptic Cospels and the liourtl fiosuel, 5.

bionysian ela, on the, 272 .

Discrepaneies, alleged, in the Gosjels, 78.

Documents employed by Luke, 227 , 228.

Doddridge's Family Expositor, 86, 160.

Dods", 1)r. Mlareus, Introduction to the $\mathrm{N}$ (w' Testament, 99, 178.

Doxology to the Lorl's prayer, 137.

Ebionites, the, $122,123$.

Ehirard's Gospel History, 64, 134, 277. Eichhorn's Synoptie theory, $56 ;$ sulposes Luke's Gospel to be an enlargement of Mareion's Gospel, 213.

Ellicott's Hulsean Lectures : on the peeuliarities of the Giospels, 85 ; on the star of the wise men, 134; defends the genuineness of Mlark xvi. 9-20, 201.

Ephrem, Syrus, his Commentary on Tatian, 15.

Epiphanius asserts that Matthew wrote in Helorew, 112; his aeconnt of Mark, 176; and of Luke, 224.

Epistle of the Churelies of Vienne and Lyons, 211.

Essays and Reviews: Dr. Jowett's essay, 73 .

Eusebius' Chureh IIistory, passim.

Evanson's Dissonance of the Four Evangelists, 237.

Expositor Articles : article ly Wace on Tatian, 16; articles by Professor Sanday on the Synoptie problem, 49, 64,99 ; article by l'yofessor Marshall on an original Illebrew Gosprel, 60 ; article by Conylueare on Aristion, the author of Mark xvi. 9-20, 199; article by lean Farrar on Mrs. Lewis' Sinaitic manuseript, 252.

Extra-anonical sayings of Christ, 125.

Fallidax's, A. M., Clunist in Modern Theolong, 21, 8:3.

Farbairn's, I)r. latriek, Ilermenentie Minmal, 163.

lanrar's Commentary on luke, 263.

Farrar suplorts the theory of an oral cospei, 52 ; his deseription of Matthew's (iospel, 110 ; rejects Mirk xvi. 9-20, 196; value of lake's (iospel, 236.
Farrar's Life of Christ, 147.

GiNEALOrY from Salmon to David, 254.

fienealogies, the, in Matthew ant Luke, 249268.

Genealories anong the Jews, 267.

Genuineness of the synoptic Gospels, 10-2*2; of Mattlew's Gospel, 91104 ; of llark's (iospel, $167-172$; of Mark xvi. 9-20, 187-191; of Luke's Gospel, 209-221.

Gethsemane, the agony and bloody sweat: its authenticity, 241-244.

Gieseler's theory of an oral gospel, 51.

Gloas, Introduction to the Jolnannine Writings, 5; Introduction to the l'auline Epistles, 75 ; Introluction to the Catholic Eiristles, 143.

Ginostieism of Marcion, 215.

Godet's billieal Studies, 40, 108 ; Commentary on Luke, 50, 266, 267. Goethe's Testimouy to the Ciosjels, 22. Gospels: meaning of the wort gospel, 3 ; their fiogmentary nature, 8 ; symbols, 9 ; relation of the synoptic fiospels to each other, 22 ; points of agreement, 23 ; sections common to all three, 24-28; sections common to Matthew and Mark, 28-30; seetions common to Mark aud Luke, 30 ; sections eommon to Matthew and Luke, 30-33; sunmary of eoincidences, 35 ; points of differenee, 38 . (iusperl aecording to the Hebrews, 120126.

Greek Testament, eritieal editions of, 72 .

Gresswell's Iissertations, referred to, $80,88,113,119,174$.

Griesbach's New Testmuent, 72 ; theory of depentence, 44.

Gucricke, Isagogik, referred to, 7,133 , 178.

I Ans's Evangelium Marcion, 213, 220.

Halcomb: What think ye of the Gosprels? 88.

Halmony of the Gospels, 85-89.

llarnak's History of loogma, 215.

Harris, I. Rentel, on the (iospel of J'eter, 14.

II ausrath's Ilistory of the New Testa. ment Times, 76.

Iebrew Christians, Matthew's Crospel written for, 108.

Ifeluew the original language of Matthew's Gospel, 110-120.

Ilegesipuns, yuoted, 1:21.

Homphill's loiatessaron al Tatian, 16.

llenterson, Commentary on Zechariah, 165. 
Herod the Great : his cruelties, 135 ; year of his death, 273.

Hervey's Genealogies of Jesus Christ, referred to, $249,255,260$.

Herzog's Encyclopädie, article on Tatian, 17.

Hesychins of Jerusalem, his evidence on the concluding paragraph of Mark's Gospel, 193.

Hilary, Bishop of Poictiers, quoted, 241.

Hill's Divinity Lectures, referred to, 152.

Hill, Rev. J. Hamlyn, translation of Tatian's Diatessaron, 16 ; Marcion's Gospel, 217.

Hippolytus, quoted, 195, 242.

Hobart, Medical Languarge of St. Luke, 223.

Holtzmann's Einleitung, 2, 24, 39, 55, 63 , Kommentar, 22 ; his two document hypothesis, 63 .

Hort, Dr.: Critieal edition of N. T., 72 ; rejects the doxology of the Lord's prayer, 139 : consider's Mark xvi. 9-20 not genuine, 200 ; his remarks on Luke iv. 14, 239.

Hug's Introduction to the New Testament, 126.

IGNaTius: his testimony to the Gospel of Matthew, 95 ; alludes to the star of Bethlehem, 131.

Inspiration of the Synoptic Gospels, 77, $81,82$.

Integrity of Matthew's Gospel, 128139 ; of Mark's Cospel, 187-201; of Luke's Gospel, 237-244.

Interpretation of the Synoptic Gospels, 71-85.

Irenæus: on the number of the Gosjels, 7 ; the Gospel symbols, $9-10$; testimony to the genuineness of the Synoptic Gospels, 10 ; of Matthew's Gospel, 96 ; mentions the visit of the magi, 132 ; testimony to Mark's Gospel, 169 ; to Luke's Gospel, 211 ; mentions the bloody sweat in Gethsemane, 242; asserts the Davidic descent of Mary, 264.

JAMEs, Epistle of : apparent referenees in it to the Sermon on the Mount, 91.

Jehoiakinı : omitted in the genealogy given by Natthew, 256.

Jerome: on the Gospel symbols, 10 ; on the language in which Matthew wrote his Gospel, 112 ; supposes that the reference in Matthew xxvii. 9, 10 is to a lost prophecy of Jeremial, 160 ; on Mark as the interpreter of Peter, 178 ; attests the existence of mann- scripts terminating Mark's Gospel at xvi. 9, 193.

Jones' Callon of the New Testament, $97,103$.

Josephus : on the language of Judra, 127 ; no reference in his history to the massacre of the infants of Bethlehem, 135 ; on the Jewish genealogical tables, 267 ; the Jews had to take an oath of allegiance to Augustus, 272 .

Jowett on the interpretation of Scripture, 73 .

Judæa, the language of, 126 .

Justin Martyr: his use of the term Gospel, 4; his testimony to the Synoptic Gospels, 17 ; to Matthew's Gospel, 96 ; mentions the visit of the Magi, 131 ; testimony to Mark's Gospel, 168 ; to Luke's Gospel, 210 ; mentions the bloody sweat in Gethsemane, 242 ; alludes to the census of Quirinius, 275.

KePLer on the star of the wise man, 133.

Kerr's Introduction to New Testament Study, 203.

Kidder's Dissertation on the Messiah, 162.

Kirchhofer's Quellensammlung, 10, 97.

Kitto's Cyclopedia, 265.

Kuinoel, Novi Testamenti Libri Historici, 201.

LACHMANN's Testamentum Gracnm, $72,189$.

Language of Matthew's Gospel, 110128 ; of Mark's Gospel, 183-187; of Luke's Gospel, 230, 231.

Language of Judrea in the time of Christ, 126.

Latin expressions in Mark's Gospel, 181.

Latin version (the old Italic), 20.

Lee, Archdeacon, Inspiration of the Holy Scriptures, referred to, 118.

Levi, supposed to be different from Matthew, 105.

Lewis, Mrs., the Sinaitic Palimpsest, 251.

Lightfoot, Dr. John, quoted, 162, 175, 268.

Lightfoot's Essays on Supernatural Religion, 65 ; the Apostolic Father's, 94.

Logia, meaning of the term as used by Papias, 65.

Lord's prayer, the, as given in Lnke's Gospel, 240 .

Luke, Gospel of : its genuineness, 209 221 ; its relation to Marcion's Gospel, 
218 ; its anthor, 221 ; soures, 225 : lesign, 2.25 ; langlage, 230 ; chatateteristics, 231 ; integrity, 237 ; date, 244 ; contents, 247 .

Luke, the Evangelist : notiens of, in Seripture, 22:2-2:1; in Church history, 225.

M.N'rear's Commentary on Mark, 17s, 187.

M'Clolan's New Testament, so, 134, $161,193$.

Maci, visit of the, 133.

Mansel's Commentary on Matthew's Gospel, 158, 263; Gnostic heresies, 215.

Mamuseripts of the New Testament, $72,73$.

Marion: Gospel of, 8 ; sketeh of his life, "213; works in relation to his Gospel, 213; his vicus, 215; relation of his Gospel to thiat of Luke, 218 .

Mark, Gospel of : litorature, 167 ; grenuineness, $167-172$; antlor, 172 ; sourees, 177 ; lesion, 181 ; waraeteristics, 185; integrity, 187-191; lite, 202-208; eontents, 207.

Mark, the Evangelist: notices in Sirripture, 172; supposition of two Mlarks, 174; supposel to be the young man who follower Christ, $175 ;$ notices in ecelesiastical lis. tory, 176.

Marsh, lishop, his theory of the formation of the tiospels, 57.

Marshall, Prolessor, (n) the Aramaie (iospel, 60 .

Mary, Luke gives the genealogy of, $26,-267$.

Massace of the infants of bethlehem, 13.5.

Matthew, (rosperl of: literatule, 00 ; genuineness, \$0-104; author, 104 ; somrees, 106; flesign, 108; language, 111-128; intererity, 12:4-13!! ; dite, $1301.14 ;$;ontents, 111 .

Natthew, the Evangelist: notions in seripture, 101; stlpusacel to J lilferent from Levi, 105: motios in towesiatstiol history, 106.

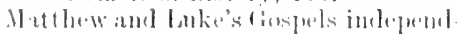
rut uf +iuble ot lier, 50 .

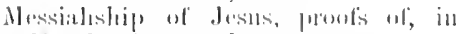
Matthow's limsmel, 109.

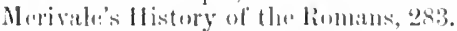
Meyor's Commentaly wn Matthew, :99, $117,129,165,257$; (ommluntily" on Mark, 172; Commentaly on luke, 225,213 .
Michachis' lutroduction to the New 'Testiment hy Bishop Marsh 57,143 , $155,161,197$.

Milligin, Professor, mantains the genuineness of the Wistle of Barnalus, ?.t.

Mommsin's l'rovinces of the loman Buplime, 292.

Morison's communtary on Matthew, $119,16 t, 257$.

Morison's Commentaly on Mark, 201.

Muratorian canon, 14, 168, 211.

Mutual relations of the symoptic Gospels, 22-4:.

Ilythieal incilents supposed to be in Matthew's Gospel, 102.

Naradive, the threefold, 24; tho twofoll narrative: Matthew and Mark, 28; Mark and Luke, 30; Matthew and Luke, 30 ; the single nurrative: Matthew, 32 ; Mark, 33 ; Luke, 3:3.

Nazarenes and Ebionites ristinguished, 122.

Nazarites, the, 157.

Neander's Lif' of Christ, 135.

Nicephorus, IIist. Eecl., 177, 224.

Nicholston's (rospel aceording to the Helnews, 123.

Norton's Genuineness of the Gosprels : on the early ditlision of the Gospels, 12 ; on the verbal agreements in the Cospels, 36 ; supports the theory of oral tralition, 52 : supposes thit there aremythical additions to Mathew's fiosprel, 102; denies the anthenticity of the first two ehapters of Matthew's Gospel, 1:2!; considers the visit of the mani to be legendary, 133 : rejects Luke's aerount of the lolouly sweat, 242 ; consillers the genealoug given by Mattlew to be an interpolation, 250 .

Obirsoness to the erenumeness of

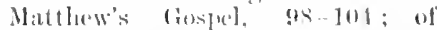
Mark's riospel, 170 17:2: ul huke's (iosfuel, 213 -201.

Olshansen un the (iospels, 10, 21:3.

Origen distimetishes luetweren Matthew amel Levi, 105: testimmer to it Hohrew Matthew, 111 ; on the

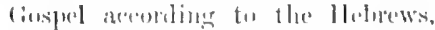
12.2 : enonetion letween Lukr amb l'atıl, '2:'s.

Osiamder's IIarmonia evangeliorm, $5 \%$

l'AuEv's Evilubes, 1s. 
Pantenus, his testimony to a Hebrew Matthew, 111.

Papias, extract from, 18 ; his referenees to Matthew and Mark, 62; meaning of the logia of Mlathew, 65; allusion to the Gospel of Matthew, 96 ; Matthew composed his works in the Hebrew langnage, 107, 111; his testimony to Mlark's Gospel, 168; Mark did not write in order the things said or done by Christ, 170.

Parables of our Lord, 82 ; those peeuliar to Luke's Gospel, 248.

parallels between the Sermon on the Mount and the sayings of our Lord recorded by Luke, 39 .

Paul, his relation to Luke, 224.

Peter, the Gospel of, 12, 13.

Peter, connection between him and Mark, $177-180$.

Pfleiderer's Gifford Lectures, 63.

Philippi's Commentary on the Romans, 65.

Place of composition of Matthew's Gospel, 143 ; of Mark's Gospel, 205 ; of Luke's Gospel, 247 .

Polycarp: testimony to Matthew's Gos. pel, 96 ; his encounter with Mareion, 214.

Pritchard, Rev. Charles, on the star of the wise men, 133.

Quirinius, census of, 269-284.

Quotations from the Old Testament in Matthew's Gospel, 140-166 ; in Mark's Gospel, 184, 185.

RAmsay, The Chureh and the Roman Empire, 95.

Resch's Agrapha, 60, 64, 70, 124.

Reuss' History of the New Testament, 62.

Revised Version, 74.

Roberts, Greek the Language of Christ and His Apostles, 126, 149, 151; article in the Thinker on the genealogy of Christ, 267.

Row, Jesus of the Evangelists, 46 ; Bampton Lectures, 78, 81 .

Rushbrooke's Synopticon, 24, 39, 86.

Salmon's Introduction to the New Testament, referred to, $14,24,48$, $68,77,171,219$.

Sanday: articles in the Expositor, 49, 64, 99 ; Bampton Lectures, 13, 62, 78,161 ; his views on the sources of the Synopties, 64 .

Saturninus Sentius, supposed to bc governor of Syria when Christ was born, 276.

Sayings of Jesus, collection of, 68 .

Sehaff, Dr. : independence of the Gospels, 46; sourees of the Synoptic Gospels, 52 ; two editions of Matthew's Gospel, 11s; style of Matthew, 128 ; langrage of Lnke, 231.

Schaff's Oldest Church MIanmal, 91.

Schleiermacher, hypothesis of, 58 ; critical essay on Luke's Gosprel, 227 . Schmid's Biblical Theology of the New Testament, 91.

Schïrer, Jewish People in the Time of Christ, 76, 127, 281, 283.

Serivener : on Matthew vi. 13, 138 ; on Mark xvi. 9-20, 187-201; on Luke ii. 14, 239 ; on Luke xxiii. 43, 44, 244.

Septuagint, nse of, 149.

Serapion, on the Gospel of Peter, 12.

Sermon on the llount, the, 29, 82-84.

Sinaitic Syrian manuseript, 251-253.

Sinaitic and Vatican manuscripts, relation of, 189, 190.

Smith's Dictionary of the Bible, 55, $64,113$.

Smith of Jordanhill, Dissertation on the GospeIs, 59.

Socrates' Chureh History, 106.

Sources of the Synoptic Gospels, 4271 ; of Mattliew's Gospel, 106-108; of Mark's Gospel, 177-1S1; of Luke's Gospel, 225-228.

Speaker's Commentary, 35, 149, 190.

Spiritual discernment neecssary for interpretation, 81.

Spiritual songs in Luke's fospel, 236.

Stanley, Dean, Sermons on the Apostolic Age, 174 .

Star of the wise men, 133.

Strabo on Quirinius, 281.

Strauss' mythical theory, 21.

Stroud's Greek harmony of the Gospels, $35,45,86$.

Stuart, Moses, Greek the origina language of Matthew's Gospel, 116. Style and diction of Mattliew's Gospel, 127; of Mark's Gospel, 183; of Luke's Gospel, 230, 231.

Suetonius, quoted, 273.

Swete on the Gospel of Peter, 13.

Synoptic, meaning of the term, 5 .

Synoptic Gospels: their number, 6 ; authors, 9 ; symbols, 9,10 ; genuineness, 10-22; relation to each other, 22-43; points of agreement, 23 ; points of differcnce, 38 ; sources, 42-71; interpretation, $71-84$; jeculiarities, 84 . 
Syraic version, 20.

Syria, governors of, 281.

TArites, puoted, $272,274,281$.

Tatian's Diatessaron, 14-17 ; omits the genealogies, 130 ; contains Mark xvi. $9-20,194$.

Teaching in the Synoptic Gospels compared with the teaching in the other books of Seripture, 83, 84 .

Tertullian : genuineness of the Synoptic Gospels, 11 ; Gospel of Mark ealled the Gospel of Peter, 177, 180; on Mark's Gospel, 218 ; statement concerning the census of Quirinius, 276 .

Theoloret, quoted, 15.

Theophilus, Luke's Gospel addresser to, $228,229$.

Theories, Synoptic : theory of mutual dependence, 44-81; of an oral grospel, $51-56$; of an original document or documents, $56-61$; the two doeument theory, 61-66.

Theories of reeonciliation of the two genealogies: a levirate marriage, 260-263; both give the genealogy of Joseph, 263-265 ; Luke gives the genealogy of Mary, 265-267.

Thirlwall, translation of Sehleiermacher's Luke, 58.

Tholuek's Sermon on the Mount, 40, 83.

Tisehendorf's Greek Testament, $72,188$.

Townson, hypothesis of a Greek and Hebrew edition of Matthew, 118.

Tregelles, Canon Muratorianus, 14 ; Greek Testament, 72 ; Hebrew the original langrage of Matthew, 113 ; Printer Text of the New Testament, 188, 191; rejects Mark xvi. 9-20, $188,196$.

Turpie, The Old Testament in the New, 146 ff ; The New Testament View of the old, 162.
Ur-Malicus, the hypothesis of an, 66 , 71,171 .

VATICAX and Sinaitic mamuseripts, their comnection, 190; the Lord's grayer as given in the Vatican manuseript, 240.

Volkmar, Das Evangelium Marcion, 219.

WACE's articles on Tatian'sDiatessaron, 15.

Warfiel,], Professor, quoted, 203.

Weiss, Bernard, Einleitung, 63.

Weizsäeker's Apostolisehes Zeitalter, 50,62 .

Wendt, Lehre Jesu, 64, 69.

Westeott on the Canon, 20.

Westeott's Introdnction to the Study of the Gospels, 35, 42, 52, 69, 113, 188.

Westeott and Hort's Greek Testament, $21,72,187,198$.

Wieseler's Synopsis of the Four Gospels, 86, 134, 137, 278.

Winer's Biblisches Wörterbueh,134,269.

Winer's Grammar of N.T. Greek, 278.

Wiseman, Cardinal, 76.

Women, prominence givel to, in Luke's Gospel, 235.

Wordsworth's Greek Testament, 164.

Wright, Rev. A., Composition of the Four Cospels, 83.

Wright's Bampton Lectures, 165.

I'EAR of our Lord's birth, $272,283$.

Zechanial, the son of Barachiah, murder of, 142.

Zahn's Tatian's Diatessaron, 16.

Zeller's Aets of the A postles, 212, 219.

Zerubbabel in the Genealogies, 258$260,267$.

'Zumpt's investigations coneerning the governorship of Quirinius, 280-284. 


\section{T. and T. Clark's Publications.}

\section{WORKS BY PATON J. GLOAG, D.D.}

Now ready, in demy 8 vo, price $7 \mathrm{~s} .6 \mathrm{~d}$., INTRODUCTION TO THE SYNOPTIC GOSPELS.

In demy 8 vo, price 10 s. $6 \mathrm{~d}$.,

\section{INTRODUCTION TO THE CATHOLIC EPISTLES.}

'Dr. Gloag, whilst courteous to men of erudition who differ from him, is firm and fearless in his criticism, and meets the erudition of other's with an equal erudition of his own. $\mathrm{He}$ has displayed all the attributes of a singularly accomplished divine in this volume, which ought to be eagerly welcomed as a solid contribution to theological literature; it is a work of masterly strength and uncommon merit.'-Evangelical Magazine.

' We have here a great mass of facts and arguments relevant in the strictest sense to the subject, presented with skill and sound judgment, and calculated to be of very great service to the student.'-Literary Churchman.

\section{In crown 8vo, price 5s., \\ EXEGETICAL STUDIES.}

'Careful and valuable pieces of work.'-Spectator.

'A very interesting volume.'-Literary Churchman.

- Dr. Gloag handles his subjects very ably, displaying everywhere accurate and extensive scholarship, and a fine appreciation of the lines of thought in those passages with which he deals.'-Baptist.

'Candid, truth-loving, devout-minded men will be both instructed and pleased by studies so scholarly, frank, and practical.'-Baptist Magazine.

In crown $8 \mathrm{vo}$, price $7 \mathrm{~s} .6 \mathrm{~d}$,

\section{THE MESSIANIC PROPHECIES, BEING THE BAIRD LECTURE FOR 1879.}

'It has seldom fallen to our lot to read a book which we think is entitled to such nnqualified praise as the one now before us. Dr. Gloag has displayed consummate ability.'-London Quarterly Review.

'We regard Dr. Gloag's work as a valuable contribution to theological literature. We have not space to give the extended notice which its intrinsic excellence demands, and must content ourselves with cordially recommending it to our readers.'-Spectator.

In demy $8 v 0$, price 128 .,

\section{INTRODUCTION TO THE PAULINE E P I S T LES.}

'A work of uncommon merit. He must be a singularly accomplished divine to whose library this book is not a welcome and valuable addition. - Watchman.

In Two Volumes, 8 vo, price 21s.,

\section{A CRITICAL AND EXEGETICAL COMMENTARY ON THE ACTS OF THE APOSTLES.}

' This commentary of Dr. Gloag's I have examined with special care. For my purposes I have found it unsurpassed by any similar work in the English language. It shows a thorough mastery of the material, philology, history, and literature pertaining to this range of study, and a skill in the use of this knowledge which places it in the first class of modern expositions.'-H. . Hackett, D.D. 


\section{T. and T. Clark's Publications.}

\section{Just publishcd, in dcmy sio, price 10s. 6d., THE EARLIEST LIFE OF CHRIST EVER
COMPILED FROM THE FOUR GOSPELS, BEING 'THE DIATESSARON OF TATIAN' \\ Literally Translated from the Arabic Version, and containing the Four Gospels woven into One Story.}

Tuith an בlyistorical and Critical Entroduction, Notrs, and Appendix, BY REv. J. HAMLYN HILL, B.D.

Tho Bismop of Gloucester and Bustol writes:- "This is a work of vory great importance, and of unique interest. It has lwen given to the world in an admirable form, aud reflocts tho greatest eredit on the able and conseientions Editor. The history of the work, as told in a elear and well-written Introduction, will enablo the reader to appreciate tho vast care and pains that have been bestowed on this singular recovery of the first Ifarmony of the Gospels. T'he Notes are short, clear, and helpful; and the eleven Apuondices of a practical value, which tho general reader will as fully rocognise as the seholar and critic. Mr. Hamlyn libll has porformed the diffieult dity of Iiditor with cons],icuous success.'

'Truly an excollont piece of work, which wo commend most warnly to the student and to the goneral reader. Tho problems raised by the Diatessaron aro by no means yet exhausted, and every ono who takes an interest in the question of the Gospels ought to make himself aequainted at first hand with the material on which we have to work. Such could not be more easily or safely studied than in Mr. Ilamlyn Hill's fascinating volume.'-Church Bells.

\section{Just pullished, in Tuo l'olumes, 8ro, price $21 s$,

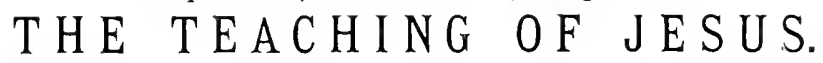

By Professor HANS HINRICH WENDT, D.D., JENA. Translated by Rev. JOHN Wilson, M.A., Montreux.

'Dr. Wendt's work is of the ntmost importance for the study of the Gospels, both witl regard to the origin of them and to their doctrinal contents. It is a work of distinguished leaming, of great originality, and of profonnd thought. Tho second part [now tranglated into English], which sets forth the contents of the doctrine of Jesus, is the most important contribition get made to biblical theology, and the method and rosults of Dr. Wondt deservo the closest attention. . . No greater contribution to the study of biblical theologg has been male in our time. A brilliant and satisfactory exposition of the teaching of Christ.'-Prof. .I. Iveracu, D. D., in The Expositor.

"Dr. Wendt las produced a romarkably fresh and suggestive work, deserving to be ranked among the most important contributions to biblical theology. . . Thero is hardly a page which is not suggestive; aud, apart from the general value of its conclusions, thore are numorous specimens of ingenions exegesis throw ont with more or less confidence as to particular passages.'-Prof. W. P. Dicksos, D.D., in The Critical Review.

'A book that no student can afford to neglect.'-Review of the Churches. In demy sio, mice 10s. Gd.,

\section{COMMENTARY ON ST. PAUL'S EPISTLE TO THE EPHESIANS.}

\section{By Rev. JOHN MACPHERSON, M.A., Findhorn.}

'It is an advance, and a grat one, on anything wo yot possess. . . The author goes to tho root, and negleets nothine that wsially comes imer the rye of a careful student. . . Besides all this, tho book is a living book. One is constious of the hoart of a man in it, as woll as the brains.'-Methodist Times.

"This is a vory landsome volume which Mr. Macpherson has griven us, and without any doulst it will take the first place among the eommentaries devoted to this liptle. 'l'te Introduction is fuller far than we lave aver hasl. It is quite in touch with the latest literary and arelanologiral results-resultis which, in this particular Epistlo, have recently como in with mmsual richness. 'l'hat alono is sufticiont to give this volume the pre-eminence.'-The lixpository Times. 


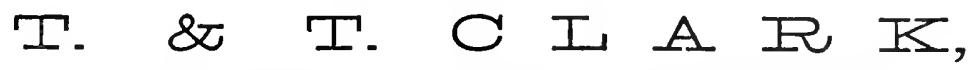

38 GEORGE STREET, EDINBURGH. LONDON: SIMPKIN, MARSHALL, HAMILTON, KENT, \& CO. LIMITED.

Adam (J., D.D.) - An Exposition of the Epistle of James. Svo, 9s. Ahlfeld (Dr.), etc.-The Vorce from the Cross. Cr. 8ro, price $5 \mathrm{~s}$. Alcock (Deborah)-The Seven Churches of Asia. 1s.

Alexander(Prof.W.Lindsay)-BiblicalTheology. Two vols. Svo, 21 s. Allen (Prof. A. V. G.)-Life of Jonathan Ldwards. Fcap. Svo, $5 \mathrm{~s}$. Andrews (S. J.) - The Life of our Lord. Large post 8 ro, 9s.

Ante-Nicene Christian Library-A ColleCTION OF NLL THE WORKS of the Fathers of tue Chustian Chunch prior to the Covscil of Nicka. T'wenty-four vols. 8vo, Subseription price, $26,6 \mathrm{~s}$.

Augustine's Works-Edited by Marcus DoDs, D.D. Fifteen vols. 8 vo, Subseription price, $£ 3$, 19s. nett.

Balfour (R. G., D.D.)-Cential Trutis and Side Issues. Crown 8vo, 3s. 6rt.

Bannerman (Prof.)-The Church of Christ. Two vols. 8vo, $21 \mathrm{s.}$

Bannerman (D. D., D.D.) - The Doctrine of the Church. Svo, 12s. Baumgarten (Professor)-Apostolic History. Three vols. 8vo, 27. Bayne (Peter, LL.D.)--The Free Church of Scotrand: Her Origin, lounders, aul Testimony. P’ost $8 \mathrm{vo}, 3 \mathrm{~s}$. 6d.

Beck (Dir.) -Outlines uf Biblical Psychology. Crown Sro, 4s.

Pastoral Theology in the New Testament. Crown 8vo, $6 \mathrm{~s}$. Bengel-Gnomon of the New Testament. With Original Notes, Explanatory and Illustrative. Five vols. 8vo, Subscription price, 31s. 6u. Chectper Evdition, the five volumes bound in three, $24 \mathrm{~s}$.

Besser's Christ the Life of the World. Price 6s.

Beyschlag (W., D.D.) - New Testament Theology. Two rols. demy Svo, 1Ss. nett.

Bible-Class Handbooks. Crown 8vo. Forty Volumes, 1ld. to 3s, eaeh. Elited by Prof. Marcus Dons, D.D., and Alex. Whrte, D.D. Detailed List free on applicution.

Bible-Class Primers. T'wenty-Eight now issued in the Series. Editer by Prof. S. D. F. Salmoxn, D.D. Paper covers, 6il. each ; free by post, 7 d. In cloth, 8d.; free by post, 9d. Detailed List five on application. Blaikie (Frof. W. G., D.D.) - The Preaciers of Scotland From the 6ti to the 19tu Century. Post 8ro, 7s. 6d.

Blake (Buchanan, B.D.) - How to Read trie Propiets. Part I.The Pre-Exilian Minor Prophets (with Joel), 4s. Part II.-Isaiah (ch. i.xxxix.), 2s. 6ul. Paltifl. - Teremiah, 4s. Part IV.-Ezzekiel, 4s. I'art.Y. -Isaiah (eh. xl.-lxvi.), and the Post-Exilian Prophets.

Bleek's intronuction to the New Testament. Two vols. 8vo, $21 \mathrm{~s}$. Briggs (Prof.)-Biblical Study. Fourth Edition, post 8vo, $7 \mathrm{~s} .6 \mathrm{~d}$.

- American Presigterianism. Post 8vo, 7s. 6d.

- Messianic Prophecy. Post Svo, 7s. 6d.

The Messiail of the Gospels. Post 8vo, 6s. 6d.

- The Messiah of the Apostles. Post 8vo, 7s. 6d.

Whither? A Theological Question for theTimes. Post8vo, 7s.6al. The Bible, the Churcit, and the Reason. Post Svo, 6s. 6c.

Brockelmann (Dr. C.) - A New Syriac Lexicon. With a Preface by Prolessor T. Noldeke. Crown 4to, 30s. net t. 
Brown (David, D.D.)-Christ's SLConil Coming: "Will it be PreHillenuial? Seventh Elition, crown Sro, 7s. 6ul.

Bruce (A. B., D.D.)-The Tranisg of 'rie Twesve; exhibiting the

T'welve Disciples umler Iiseipline for the A postleship. 5th E.l., 8vo, 10s. 6d. Tine Humilation of Chlist. Brel Ed., Sro, 10s. Gd.

The KIngdon of Gou ; or, Christ's Teaching according to the

Symoptieal Gospels. New Elition, 7s. 6ol.

Bruce (A. 13., D.D.) - Apologerics: OR, Christianity Defensivily stated. Post 8ro, Second Edition, 10s. Gil.

St. Palis's Conchpton of Chintinity. Post Sro, 7s. 6d.

Brnce (W. S., M.A.) - The Ethics uf the Old Testanext. Cr. 8vo, 4 s.

Buchanan (Professor)-The Doctrine of Justificatios. 8ro, 10s. 6d.

On Comfort in Affliction. Crown 8ro, 2s. 6d.

On Improvement of Affliction. Crown 8vo, 2s. $6 \mathrm{~d}$.

Buhl (Prof.) - Canon and Text of the Old Testanext. 8vo, 7s. 6d.

Bungener(Felix) - Rome and tireCouncil in $19^{\mathrm{TH}}$ Century. Cr.8vo, ́́s.

Burton (Prof. E.)-Sratax of Moods and Texses in New

Tes canent Greke. Post 8ro, 5s.60l. nett.

Calvin's I nstrotutes of Christia Religion.(Translation.) 2vols.8vo, $14 \mathrm{~s}$.

Calvini Institutio Christianze Religionis. Curavit A. Tholuck.

Two rols. 8ro, Subseription price, $14 \mathrm{~s}$.

Candlish (Prof. J. S., D.D.)-The Kingdoy of God, Biblically and

Historically Cossideked. 8vo, 10s. 6d.

Caspari (C. E.)-A Chronological and Geographical IntroducTION TO THE LifF OF CHRist. 8ro, 7s. $6 \mathrm{~d}$.

Caspers (A.)-The Footsters of Christ. Crown 8ro, 7s. 6d.

Cassel (Prof.)_Commentary os Esther. Sro, 10s. 6d.

Cave (Principal A., D.D.)-The Scriptural Doctrine of SACRIfice

Axd Aronearest. Secomd Elition, 8vo, 10s. 6ul.

AN Introduction to Theology. 8vo, $12 \mathrm{~s}$.

Chapman (Principal C., LL.D.)-PRE-OrGanic Evolution AND THE Biblecte IDEA OF Gob. Crown sro, $6 \mathrm{~s}$.

Christlieb (Dr.)-Moderin Dotht and Christian Belizf. Svo, 10s. 6d. Cremer (Professor)-Biblico-Thibological Lexicon of New Testa-

M cat Greek. Third Edition, with Supllement, demy 4to, $38 \mathrm{~s}$.

Crippen (Rev. T. G.) - A PopuldR Introduction to tue History of Chintian Doctrine. Sro, 3s.

Curningham (Principal)-Histolical Theology. Two vols. Svo, 21s. Curtiss (Dr. S. I. _ - The Levitich Prinsts. Crown 8ro, 5 s.

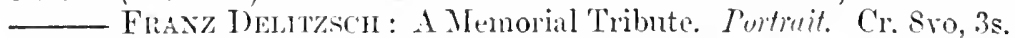

Davidson (Professor)- $\mathrm{AN}$ INTroductory Hebrew Grimmar. With

Progressive Exercises in Ravaling and Writing. Twelfth Elition, svo, 7 s. 6u.

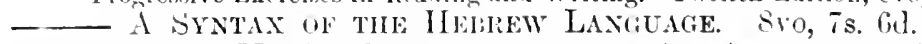

Deane (Wm., M.A.) - Psisuderigrapia: An Account of Certain Apoeryphal Writings of the Jews and Early Christians. l'ust Sro, is. bil.

Delitzsch (Prof.) - SYstem of Bublad Psycholociv, Evo, 12s.;

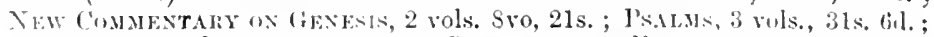

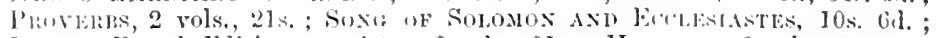

Isaldi, Fourth Edilim, rewriten, 2 vols., 21s. ; Jrmirws, 2 vols, 21 s.

Doedes-Manual of New Testament Hermeneulics. Cr. Svo, 3s.

Döllinger (Dr.) - Huppolstes ANT CAllistus. svo, 7s. Gd.

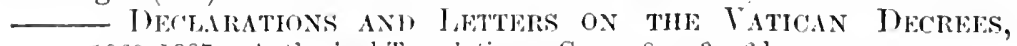
1869-1887. Authorismal Translation. Crown svo, s.s. 6ul.

Dorner (Plofessor)-IIISTORY OF THE DHVELOPILNT OF THE DOCTRINE

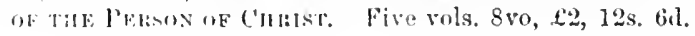




\section{T. and T. Clark's Publications.}

Dorner (Professor) -System of Christian Doctrine, 4 vols. 8 vo, £2, 2s. - Systeil of Christian Ethies. 8to, $14 \mathrm{~s}$.

Driver (Prof. S. $\boldsymbol{R}$.) - AN Intronuction to THE Literature of the Oln Testamint. Fifth Edition, with Aprendix, 8vo, 12s.

- Deuteronomy : A Criticaland Exegetical Commentary. 8vo, 12s. Duff (Prof. David, D.D.)-The EarLy C'Hureh. 8vo, 12s.

Eadie (Professor)-Commintaries on St. PAUL's Epistles to the

Eriesians, Pmimpians, Comossians. New and Revised Editions, Edited

by liev. Wa. Young, MI.A. Three vols. Svo, 10s. 6d. each; or set, 18s. nett.

Ebrard (Dr. J. H. A.)-The Gospel History. Svo, 10s. 6d.

Apologetics. Three vols. 8vo, $31 \mathrm{~s} .6 \mathrm{~d}$.

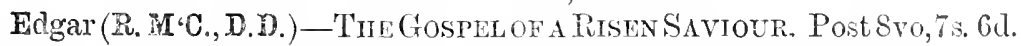
Elliott-ON THE Inspiration of The Holy Scriptures. 8vo, 6s.

IFnesti-Biblical Interpretation of New'Testament. Two vols., 8s. Ewald (Heinrich)-Hebrew Syntax. Svo, Ss, 6d.

- Revelation: Its Nature and Record. 8vo, 10s. 6r..

Old and New Testanent Thlology. 8vo, 10s. 6l.

Fairbaim (Prin.) - The Revelation of LAw in ScRipture, 8vo, 10s. 6d.

- EzEkikl And the Book of His Prophecy. 4th Ed., 8vo, 10s. 6d.

- Prophecr. Second Edition, 8vo, 10s. 6d.

Paftorat. Theolociy. Crown 8vo, 6s.
Forbes (Prof.)-Symmetrical Structure of Scripture. 8vo, 8s. $6 \mathrm{~d}$.

- Analytical Commentary on the Romans. 8vo, 10s.6d.

- Studies in tile Pook of Psiliss. Svo, $7 \mathrm{s.} 6 \mathrm{~d}$.

Time Servant of the Lomd in Isaiah Xl-Lxvi. Cr. Svo, 5s.

Frank (Prof. F. H.) -System of Christian Evidence. Svo, 10s. 6d.

Funcke (otto)-The World of FaIth AND the Everyday World, As displayed in the Footsteps of Abraham. Post 8 ro, $7 \mathrm{~s} .6 \mathrm{~d}$.

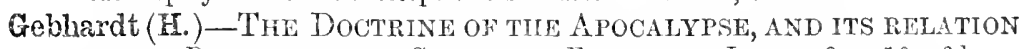
to tile Doctrine of tile Gospel ANI Episties of John. 8vo, 10s. $6 \mathrm{~d}$.

Gerlach-Comentary on the Peniteuch. 8vo, 10s. 6d.

Giegeler(Dr.J.C.․․)-Ecclestastical History. Fourvols. Svo, f2, $2 \mathrm{~s}$.

Gifford (Canon)-Voices of THE Prophets. Crown 8vo, 3s. 6d.

Given (Rev. Prof. J. J.)-The Truth of Scripture IN connection with Revelation, Inspiration, and the Canon. 8vo, $6 \mathrm{~s}$.

Glasgow (Prof.) -Apocalypse Transtated and Expounded. 8ro, 10/6. Gloag (Paton J., D.D.)-Commentary on THE ACTS. New El. prequing.

The Messianic Prophecies. Crown 8vo, 7s. 6d.

- Introduction to the Pauline Epistles. 8vo, 12s.

- Introduction to the Catholic Epistles. 8vo, 10s. 6d.

Exegetical Studes. Crown 8vo, 5́s.

Godet (Prof.)-AN Introduction to THE New Testanient : "The Eisistles of St. Paul.' Authorised Translution. 8vo, 12s. 6d. nett.

Commentary on St. Luke's Gospel. Two vols. 8vo, $21 \mathrm{~s}$.

- Commentary on St. John's Gosper. Three vols. 8vo, 31s.6d.

- Commentary on Epistle to tife Romans. Two vols. 8vo, 21s.

Commentary on 1st EPISTIE To Corinthians. 2 vols. Svo, $21 \mathrm{~s}$.

- hectures in Defence of the Christian Faitil. Cheap Ed., 4s.

Goebel (Siegfried) - The Parables of Jesus. 8vo, 10s. 6d.

Gotthold's Emblems; or, Invisible Thinas Understoon ly Thinas that are Made. Crown $8 \mathrm{vo}, 5 \mathrm{~s}$. 
Grimm's Greek-ENGlisif Lexicon of the New Testamext. Translated, Revised, and Enlarged by Joserni H. Tuark, D.D. Demy 4 to, 36 s. Guyot (Arnold, IL.D.)-Clikstion; or, The Biblical Cosmosony in the

Light of Modern Science. With Illustrations. Crown 8 ro, 5s. 6l.

Hagenbach (Dr. K. R.)-History of Doctrines. 3 vols. 8 ro, $31 \mathrm{s.} 6 \mathrm{~d}$. History of the Reformation. 2 vols. 8vo, $21 \mathrm{~s}$.

Halcombe (Rev. J., M.A.) - What THink YE OF THE Gosples? A Handbook of Gospel Study. Sro, 3s. 6d.

Hall (Newman, D.D.) - The Lord's Prayer. Crown 8ro, 6s.

GethsenaNe; or, Leaves of Hcaling from the Garden of Grief. Crown 8 ro, 5 s.

Divine Hrotheinood. Crown Sro, ts.

Hamilton (T., D.D.)-Beyond tire StaRs; or, Heaven, its Inluabitants, Occupations, and Life. Third Edition, crown 8 ro, 3s. 6ul.

Aarless (Dr. C. A.) -Systeni of Cinistian Etilics. Svo, 10s. 6d.

Haupt (Erich)_The First Epistle of St. Jolln. 8ro, 10s. 6d.

Hävemick (H. A. Ch.)-Introduction to Old 'Testanent. 10s. 6d.

Heard (Rev. J. B., M.A.)-Tine Tripartite NATURE of MAN-Spirit, Sott, ANy Bony. Fifth Edition, crown 8 ro, 6 s.

Old and New Theology. A Constructive Critique. Cr: 8ro,6s.

Alexandian and Cartinaginian 'Theolggr Contrasted.

The Ifulsean Lectures, 1892-83. Crown 8vo, 6s.

Hefele (Bishop)-A History of the Counchls of the Church. Vol. I., to A.D. 325 . Vol. II., A.D. 326 to 429 . Vol. III., A.D. 431 to the close of the Council of Chalcedon, 451 . Vol. IV., A.1. 451 to 680 . 8vo, I 2s. each.

Hengstenberg (Professor) -Commentaliy on Psalms, 3 vols. Svo, 33e.;

Ecclesiastes, err., Syo, 9s. ; Ezekiel, 8vo, 10s. 6d. ; Tae Gexuresess GF DANiel, ETc, 8 vo, 12s.; History of THe Kisgpom of Gon, 2 vols. 8vo,

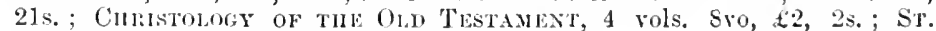
JoIre's Giostits, 2 rols. 8 ro, $21 \mathrm{~s}$.

Hill (Rev. J. Hamlyn, B.D.)-The EArliest Life of Chisist

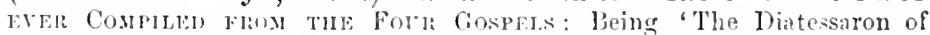
Tatian' Literary 'Translated from the Arabio Version, and containing the Four Gospels woven into one Story. With an IIistorical and Critical Introduction, Notes, anl Aplendix. Svo, 10s. 6l.

IIutchison (Johm, D.D.)-Commintary on Thissalonians. 8vo, 9s. Commentaliy on Pindiplans. 8vo, 7s. 6l.

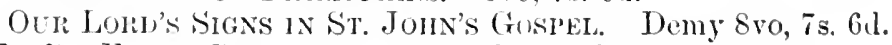
Janet (Paul)-Final, Causes. Seconl Edition, demy sro, 12s.

The Theoliy of Morals. Demy 8vo, 10s. $6 \mathrm{~d}$.

Johnstone (Prof. R.. D.D.) -Commentary oN lst PETER. Svo, 10s. 6il, Jones (E. E. C.)-Eliments of Loric. 8vo, 7s. 6d.

Jomfroy-Philosophical, Essays. Feap. 8vo, 5s.

Kaftan (Prof. Julins)-Tin: Truti of tue Cinistan Riligion. Authorised Truenstulion. "2 vols. Sro, los. nett.

Kant-Tine Metapiysic of EThics. Crown 8 ro, $6 \mathrm{~s}$.

- Phllosophy of Iaw. Trans. by IV. Mastie, B.D. Cr.8vo,5s. P'rinciples of lolitics, lite. Crown sro, 2s. 6d.

Feil (Prof.)-Pextateuch, 3 vols. 8vo, $31 \mathrm{~s}$. Gil.; Josilud, Jenges,

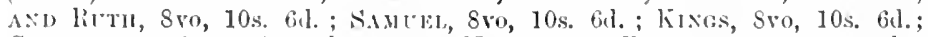

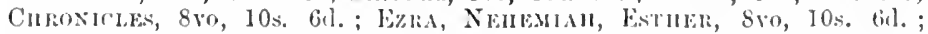

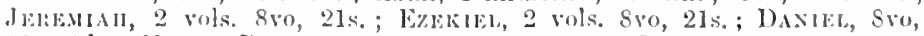

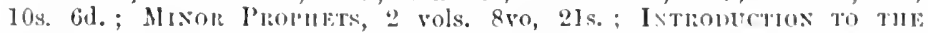

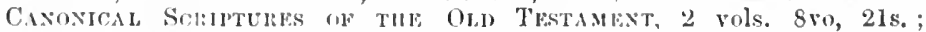
It A. 
Kennedy (H. A. A., D.Sc.) -Sources of New Testament Greek. Post 8 vo, 5 s.

Keymer (Rev. N., M.A.) -Notes on Genesis. Crown 8vo, 1s. 6d. Kidd (James, D.D.)-Morality and Religion. 8vo, 10s. 6d. Killen (Prof.) - The Framework of the Church. 8vo, 9s. Tie Old Catholic Church. 8vo, 9s.

TheIgnatian Epistles Entirely Spurious. Cr. 8vo, 2s. 6d. König (Dr. F. E.)-The Religious History of Israel. Cr. 8vo, 3s. 6d. Krummacher (Dr. F. W.)-The SUfrering Saviour; or, Meditations on the Last Days of the Sufferings of Christ. Eighth Edition, crown 8vo, 6s. David, the King of Israel. Second Edition, cr. 8vo, $6 \mathrm{~s}$. - Autobiography. Crown 8vo, 6s.

Kurtz (Prof.)--Handbook of Church History (from 1517). 8ro, 7 s. $6 \mathrm{~d}$. - History of tile Old Covenant. Three vols. 8 vo, $31 \mathrm{~s} .6 \mathrm{~d}$.

Ladd (Prof. G. T.)-The Doctrine of Sacred Scripture: A Critical, Historical, and Dogmatic Inquiry into the Origin and Nature of the old and New Testaments. Two vols. 8 vo, 1600 pp., $24 \mathrm{~s}$.

Laidlaw (Prof.)-The Biple Doctrine of Man; or, The Anthropology and Psychology of Scripture. New Edition Revised and Rearranged, post 8 vo, $7 \mathrm{~s} .6 \mathrm{~d}$.

Lane (Laura M.) - Life of Alexander Vinet. Crown 8vo, 7s. 6u. Lange (J. P., D.D.) - The Life of our Lord Jesus Cinrist. Edited by Maricus Dons, D.D. 2nd Ed., in 4 vols. 8 vo, price 28 s. nett.

- Commentaries on the Old and New Testanents. Edited by Philip Schaff, D.D. Old Testament, 14 vols.; New Testamext, 10 vols.; A pocrypria, 1 vol. Subscription price, nett, 15s. each.

- St. Matthew and St. Mark, 3 vols. 8vo, 31 s. 6d.; St. Luke, 2 vols. 8 vo, 18 s.: Sr. Jorrs, 2 vols. 8 vo, 21 s.

Lechier (Prof. G. V., D.D.)-The APostolic and Post-Apostolic Trmes. Their Diversity and Unity in Life and Doctrine. 2 vols. cr. $8 \mathrm{vo}, 16 \mathrm{~s}$. Lehmann (Pastor) - SCENES FROM THE LifE OF JESUS. Cr. 8vo, 3s. $6 \mathrm{~d}$. Lewis (Tayler, LL. D.)-The Six Days of Creation. Cr. 8vo, 7s. $6 \mathrm{~d}$. Lichtenberger (F., D.D.)-History of German Theology in the 19 Ti Century. 8vo, 1 is.

Lilley (J. P., M.A.) - Tine Lond's Surper: Its Origin, Nature, and Use. Crown 8vo, $5 \mathrm{~s}$.

Lisco (F. G.) - Parables of Jesus Explained. Fcap. 8vo, 5s.

Lotze (Hermann)-Mrcrocosmus: An Essay concerning Man and his relation to the World. Third Edition, 2 vols. 8vo (1450 pages), 36s.; Cheaper Elition, 2 vols. 8 vo, $24 \mathrm{~s}$.

Luthardt, Kahnis, and Brückner-The Church. Crown 8 vo, $5 \mathrm{~s}$.

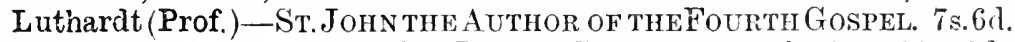
Commentary on St. Joln's Gospel. 3 vols. 8vo, 31s. 6d. History of Christian Ethics. 8vo, 10s. 6l.

Apologetic Lectures on the Fundamental ( 7 Ed.), Saving ( $5 E d$.), Moral Truthis of Christianity $(4 E d)$ ). 3 vols. cr. 8vo, 6s. each. Macdonald-Introduction to Pentateuch. Two vols. 8vo, 21s. The Creation and Fall. 8vo, 12s.

Macgregor (Rev. Jas., D.D.) - The APology of the Chisistian ReLigion. 8vo, 10s. 6d.

- The Revelation and the Record : Essays on Matters of Previons Question in the Proof of Christianity. Svo, is. 6d.

- Studies in the History of New Testanient Apologetics. $8 \mathrm{vo}, 7 \mathrm{~s} .6 \mathrm{~d}$. 
Magragor (Rev. G. H. C.) -So GREAT SiArA'Iox. 12mo, cloth, 1s.

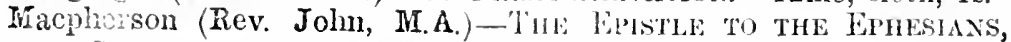
Commentary on. Sro, 10s. Gid.

M. Realsham (E. D.)-LomAsis Disseuted. A Critical Analysis of the Epistle to the liomans. Crown sro, as.

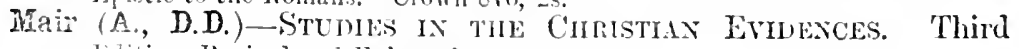
Litition, Revised and Eulargul. erowa sro, $6 \mathrm{~s}$.

Martersen (Bishop)-Christian loogmatics. Sro, 10s. 6d.

Uhristian Ethics. (Gexlika, - Individual- Social.)

Thiree rols. Sro, 10s. (ill. each.

Matheson (Geo., D.D.) - Gruw'il of tule Simit of Christianity, from tho First Century to the Dawn of the lutheran Era. Two vols. 8vo, 21 s.

Amstothestudy of Graman'Jileologr. 3rd Edition, $4 \mathrm{~s} .6 \mathrm{~d}$.

Meyer (Dr.) - Critichl and Exeghical Comnentaries on tra

Nlw Temmate. Twenty vols. 8vo. Subscription Price, f5, 5s. nelt;

Non-Subscription Price, 10s. 6al. cach volume.

Str. Matrula, 2 vols.; Mank and hekr, 2 vols. ; St. Johs, 2 vols. ;

AlTs, 2 vols, Rosass, 2 vols.; Cominturass, 2 vols.; Galatias, one vol.;

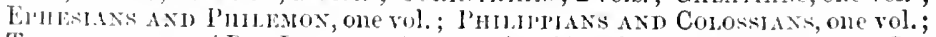

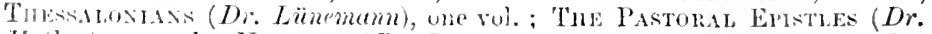

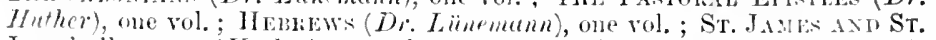

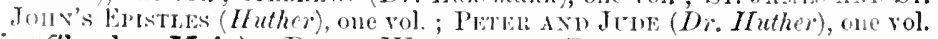

Michie (Charles, M.A.) - Prime Worms axd Phrases. $18 m o, 1 \mathrm{s.}$

Milligan (Prof. W., D.D.)-Tine Resurisection of the Dean.

Sinond Ellition, crown Sro, 4s. 6l.

Monrad (Dr. D. G.)-The Wortd of Praykr. Crown Svo, 4s. 6d.

Morgan (J., D.D.)-Scripture Tlestimony to the Holy Siritit. 7s.6d. - Exposition of THe First Epistle of John. 8vo, is. 6d.

Miiller (Dr. Julius)-Tim CinRistian Doctrine of Sin. 2 vols. 8vo, $21 \mathrm{~s}$. Iruphy (Professor)-Commentait on tile Psalis. Ero, 12s.

- A Critical and Exegeticat Commentary on Fxodus. 9s. Naville (Ernest)-Tine Problem of Evil. Crown 8ro, 4 s. $6 \mathrm{~d}$.

Tine Cimist. Translated by Rev. 'T. J. Després. Cr.8ro, 4s.6d.

Moneran Pirysics. Cromn sio, 5s.

Neander (Dr.)-C Cunnch Historr. Eight vols.' Sro, f2, $2 \mathrm{~s}$ nett.

Nicoll (W. R., LL.D.)-The Ixcanatesariour. Crown Sro, 6s.

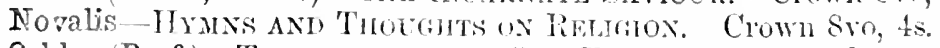

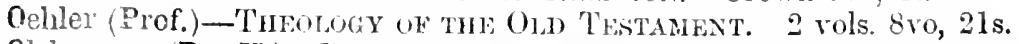

Oishausen (Dr. H.) - Bibrical Commentary on the Gospess dND

Acts. Four vols. Evo, f2, 2s. Chereper bilition, four vols crown svo, 24s.

Romans, one vol. Svo. 10s. Gal. ; Corintminss, one vol. Sro,

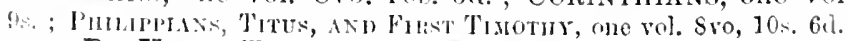

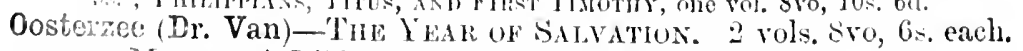

Mosfs: A Piblical Stuly. Crown 8vo, $6 \mathrm{~s}$.

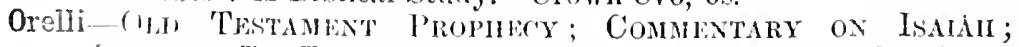
J Hom

Owen (Dr. John)-Works, liest and only Complete Editim. Edited

b. liev. Tr. Gooln. Twenty-four vols. Swo, Subserijtion price, $\mathfrak{A} 4,4 \mathrm{~s}$.

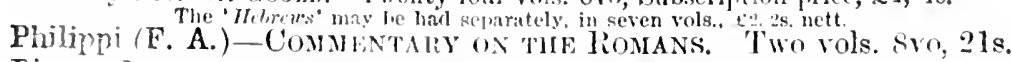

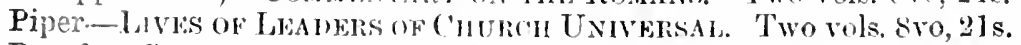

Popular Commentary on the New Testament. Filited by Pinurp

SonafF, 1). D. With Illustrations and Maps. Vol. l.-TuE Exoptical

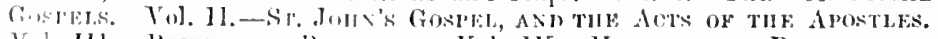

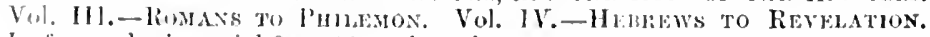

It lim vols. imperial svo, 12s. 6u. each. 


\section{T. and T. Clark's Publications.}

Pressensé (Edward de)-The Redeemer: Discourses. Crown 8ro, 6s. Pünjer (Bemhard)-History of the Christian Plillosoptir of Religion from the Refonmation to Kant. Syo, $16 \mathrm{~s}$.

Räbiger (Frof.)-Encycloredia of Theology. Two vols. 8vo, 21 .

Rainy (Principal) - Delivery and Development of Chisistan DoCTRINe. 8vo, 10s. $6 \mathrm{~d}$.

Reusch (Prof.)-Nature and the Bible: Lectures on the Mifosaic

History of Creation in Relation to Natural Science. Two vols. 8*0, 21\%.

Reuss (Professor)-History of THE SACRED SCRIPTUREs OF THE NEW

TESTAMENT. $640 \mathrm{pP} .8$ vo, $15 \mathrm{~s}$.

Riehm (Dr. E.)-Messianic Prophecy. New Edition. Post 8vo, 7s, 6d. Ritter (Carl)-Conparative Geography of Palestine. 4 yols. 8ro, $26 \mathrm{~s}$. Robinson (Rev. S., D.D.)-Discourses on Redeuption. Svo, 7s.6d. Robinson (E., D.D.) 一Greek and Eng. Lexicon of tifk N. Test. 8ro,9s. Rooke (Prof. T. G.)-Tnspiration, and other Lectures. Svo, 7 s. $6 \mathrm{~d}$. Ross (C.)-Our Father's Kinguom. Crown 8 vo, 2s. 6d.

Rothe (Prof.)-Sermons for the Ciristian Year. Cr. 8vo, 4s. 6d. Saisset-Manual of Modern Pantheish. Two vols. 8vo, 10s. 6d. Sartorius (Dr. E.)-Doctrine of Divine Love. Svo, 10s. 6a.

Schaff (Professor)-History of the Christian Church. (New Eulition, thoroughly Revised and Enlarged.) Six 'Divisions,' in 2 rols. each, extra Svo.

1. Apostolic Cimistrantry, A.D. 1-100, 2 vols. 21s. 2. ANTE-Nichere, A.D. 100-325, 2 vols., 21s. 3. Post-NICENe, A.D. 325-600, 2 vols., $21 \mathrm{~s}$. 4. Medieval, A.1. 590-1073, 2 vols., 21s. (Completion of this Period, 1073-1517, in preparation). 5. Munens, A.D. 1517-1530, 2 rols., 21s. 6. The Swiss Refonmation, 2 rols., $21 \mathrm{~s}$.

Schleiermacher's C'HRIstmas Eve. Crown 8vo, 2s.

Schmid's Biblical Tinelogy of the New Testanent. 8vo, 10s. $6 \mathrm{~d}$. Schubert (Prof. H. Von., D.D.)-The GospeL of ST. PeTer. Synoptical Tables. With Translation and Critical Aliraratus. 8vo,1s. bil. nett.

Schultz (Hermann)-Old Testamení Tileology. Two rols. 18s. nett. Schuirer (Prof.)-History of The Jewish People. 5 vols. 8 ro, $5: 6$. Scott (Jas., M.A., D.D.)-Principles of New Testament Quotation

Established and Aprlied to Biblical Criticisar. Cr. 8vo, 2nd Edit., 4s. Sell (K., D.D.) - The Cirurch in the Mirror of History. Ci. 3 ro, 36. Shedd-History of Christian Doctrine. Two vols. 8ro, $21 \mathrm{~s}$.

Serions to tile Natural Man. 8vo, 7 s. 6 d.

- Sermons to the Spiritual Man. Svo, $7 \mathrm{~s} .6 \mathrm{~d}$.

Dognatic Theology. Three vols. ex. 8ro, 12s. 6d. each.

Simon (Prof.)-The Brble; An Outgrow th of Theocratic Life. Cr. 8 vo, 4/3. The Redenption of Man. Sro, 10s. 6d.

Skene-BickelI-The Lord's Supper \& The Passover RitudL. Svo, 5s. Smeaton (Professor)-Doctrine of the Holy SpIRIT. 2nil ki, 8vo, 9s. Smith (Professor Thos., D.D.)-Medi «val Missions. Cr. 8vo, 4s. $6 \mathrm{~d}$. Smyth (Newman, D.D.) -Cinistian Ethics. 3rd. Ed. Post svi, 10s. bel. Stählin (Leonh.) -KANT, Lotze, AND Ritschl. 8vo, 9s.

Stalker (Jas., D.D.)-Life of Christ. Large Type Ed., cr. 8vo, is. 6d. Life of St. Paul. Large Type Edition, crown 8ro, 3s. 6d. Stanton (V. H., D.D.)-The Jewish and The Christian Messiah. A Study in the Earliest History of Christianity. 8vo, 10s. 6rl.

Steinmeyer (Dr. F. L.)-TIm MImarles of oUR Lord, Siro, is. 6d. 


\section{T. and T. Clark's Publications.}

Steinmeyer (Dr. F. L.)-The History of the Passion and ResurRECTION OF OUR LORD, considered in the Light of Modern Criticism. 8vo, 10 s. $6 \mathrm{~d}$.

Stevenson (Mrs.)-The Symbolic Parables. Crown 8vo, 3s. 6d.

Steward (Rev. G.)-Medratorial Sovereignty. Two vols. 8vo, $21 \mathrm{~s}$. - The Argunent of the Eistre to the Hebrews. 8vo, 10s.6d.

Stier (Dr. Rudolph)-ON the WORDs of THE Lord Jesus. Eight vols. $8 \mathrm{vo}$, Subscription price of $£ 2,2 \mathrm{~s}$. Separate volumes, price $10 \mathrm{~s} .6 \mathrm{~d}$.

The Words of the Risen Saviour, and Commentary on THE EPISTLE of St. Janes. 8vo, 10s. 6d.

The Wolds of the Apostles Expounded. 8vo, 10s. 6d.

Stiring (Dr. J. Hutchison)-Philosophy and Theology. Post 8vo, 9s. Darwinianisur: Workmen and Work. Post 8vo, 10s. 6d.

Tholuck (Prof.)--The Eristle to the Romans. Two vols. fcap. 8vo, 8s. Thomson (J. E. H., B.D.)-Books WIICH INFLUENCED OUR LoRD AND His Arosti.es. Sro, 10s. bil.

Thomson (Rev. E. A.)-Mesrorills of a Ministiy. Crown Sro, 5s. Tophel (Pastor G.)-The Work of tire Holy SpIRIT. Cr. 8vo, 2s.6d. Troup (Rev. G. Elmslie, M.A.)-WTords to Young Christraxs : Peing Adlresses to Young Commmicants. On antipue laid paper, chaste binding, crown Sro, 4s. bd.

Uhlhorn(G.)-Ciristian Charityin the AncientChurch. Cr. 8ro, 6s. Ullmann (Dr. Carl)-Reformers before the Reformatron, princi-

pally in Germany and the Netherlands. Two vols. 8 vo, $21 \mathrm{~s}$.

- 2 The Sinlessness of Jesus: An Evidence for Christianity.

Fourth Edition, crown 8vo, 6s.

Urwick (W., M.A.)-The Servant of Jehovah : A Commentary

upon Isaiah lii. 13-liii. 12; with Dissertations mon Isaiah xl.-lxvi. 8vo, 3s.

Vinet (Professor)-Studes on Blaise Pascal. Crown Sro, 5s.

Vinet (Life and Writings of). By L. M. LANE. Crown Svo, 7s. Gd.

Walker (J., D.D.)-Theology and Theologians ow Scotland.

New Elition, crown 8 vo, 3s. $6 \mathrm{~d}$.

Watts (Professor)-Tine Newer Criticisu and tire Aralogy of TuE Fartu. Third Edition, crown Sro, $5 \mathrm{~s}$.

The ReIgN of CAUSAlity: A Vindication of the Scientific

Primeiple of Telic Causal Efficiency. Crown 8vo, 6s.

The New Apologetic. Crown svo, $6 \mathrm{~s}$.

iveir (J.F., M.A.)-The Way: The Natureand Means of Salyation.

Ex. crown 8vo, 6s. 61 .

Weiss(Prof.) - Biblical'THeologr of New Thstanent. 2vols. Sro, 21s. Life of Chris'T. Three vols. 8 ro, $31 \mathrm{~s} .6 \mathrm{~d}$.

Wandt (H. H., D.D.)-The Teaching or Jests. 2 rols. Sro, $21 \mathrm{~s}$.

White (Rev. M.)-Symbolical Numbers of Scrmpurk. Cr. Sro, $4 \mathrm{~s}$. Williams-SELECT TOC.1JULARY OF LATIN ETYMology. Fcap. 8 ro, 1s. 6d. Winer (Dr. G. B.)-A Treatise on the Gramale of New TestaMENT GlEEK, regarelel as the Basis of New Testanent Exegesis. Thirl Edition, edited hy W. F. Mouron, D. D. Ninth English Elition, 8ro, 15s.

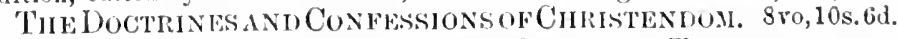

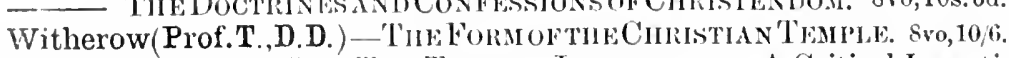
Workman (Prof. G. C.)-' 'he Text of Jeremran ; or, A Critical Investiration of the (ireck and Hebrew, etc. l'ost 8vo, as.

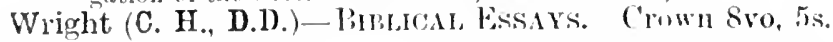





\section{Date Due}

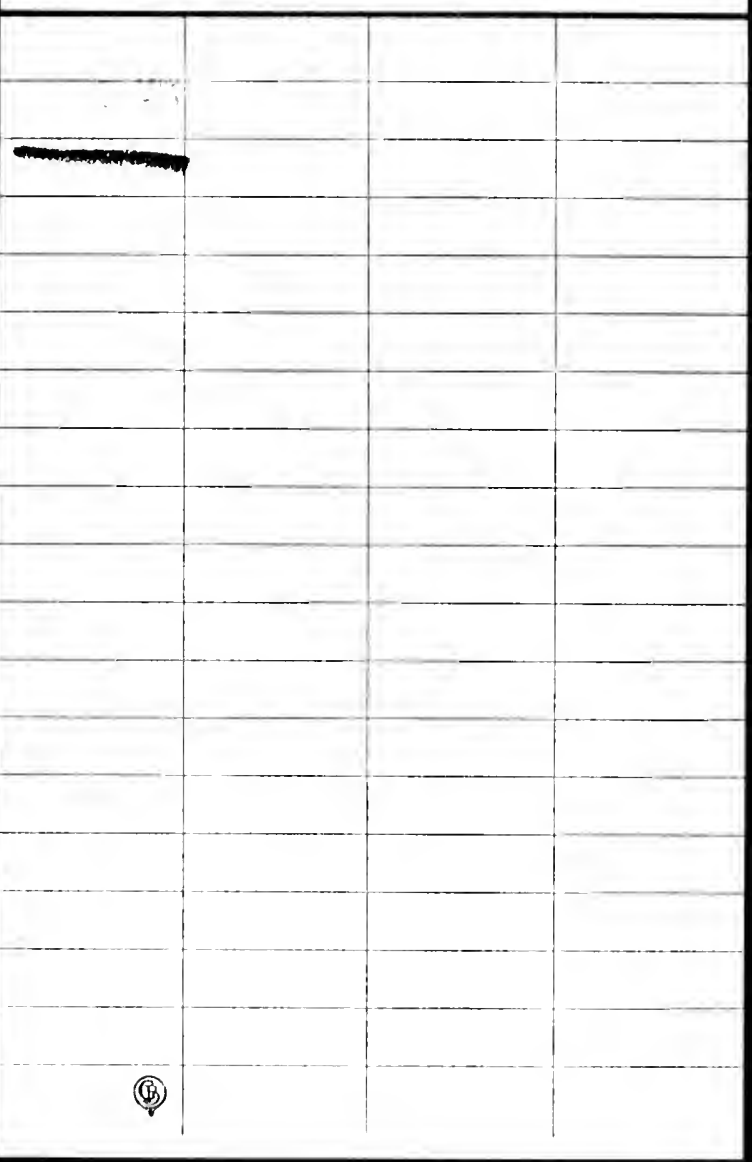



BS2569.4.656

Introduction to the synoptic Gospets

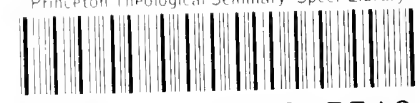
11012000135519 